\title{
SELECCIÓN DE TEXTOS ${ }^{16}$
}

\author{
Alejandra Araya Espinoza \\ Ariadna Biotti Silva \\ Nathaly Calderón Millán \\ Camila Plaza Salgado
}

16. Agradecemos muy especialmente la colaboración de la académica Azun Candina y del académico Marcelo Sánchez, ambos de la Facultad de Filosofía y Humanidades de la Universidad de Chile. 


\section{CORTAS OBSERVACIONES SOBRE LA EPIDEMOS ACTUAL DE SARAMPION I ALFOMBRILLA. COMUNICACIÓN DE DON P. ZORRILLA A LA FACULTAD DE MEDICINA EN UNA DE LAS SESIONES DEL PRESENTE AÑO ${ }^{17}$.}

Artículo presentado por el médico chileno Pablo Zorrilla (sin datos biográficos), quien durante la segunda mitad del siglo XIX publicó varios artículos en la Revista Anales de la Universidad de Chile en los que abordó principalmente el problema de la mortalidad infantil. Fue uno de los precursores de la profesionalización de la incipiente medicina obstétrica en el país.

Este documento es un estudio sobre la epidemia de sarampión que afectó a la ciudad de Santiago durante el año 1863, a la que llamó "enfermedad de nuestra patria" por su habitualidad y constancia, y sobre la que indicó que desde el año 1863 había adquirido características especiales que permitían considerarla una enfermedad epidémica: alta tasa de mortalidad, especialmente entre menores de edad, complicaciones y alargamientos de sus estadios. Finaliza su análisis haciendo una descripción de las consecuencias físicas que la epidemia ocasiona en los "enfermitos" y describe sus efectos según la parte del cuerpo afectada. Se trata de una nueva sensibilidad hacia la infancia y hacia las enfermedades, las que describe como situaciones que nadie parece considerar en su peso histórico y en su "anormalidad"

17. Zorrilla, Pablo. Medicina. Cortas observaciones sobre la epidemia actual de sarampión $i$ alfombrilla. Comunicación de don P. Zorrilla a la Facultad de Medicina en una de las sesiones del presente año, Anales de la Universidad de Chile, 1864, Santiago, p. 690-694. Disponible en: https://anales.uchile.cl/ index.php/ANUC/article/view/20156/21319 
ni oye, i confirma entónces la popular creencia de que el rio no pasa por entre esas escarpadas cordilleras.

Desde esas cumbres estended mas léjos la vista. ¡Cuán pintoresco es el paisaje! Las al tas sierras, cual enanas colinas, se postran en mil grupos a las plantas del Andes estupendo. Los mas hondos derrumbaderos soli a la distancia simples sinunsidades, i la vasta estension que abarca la vista, semeja la supericie del mar cuando la rizan los céfiros. Una larga faja de espesos vapores azulejos, descojida al ras de los picos i gargantas, atraviesa por medio del horizonte terrestre, i va a perderse en el lejano confin. Es el rir. Ha dejado los senos ocultos de las montanas, i torua cie nuevo a mostrarse, brindando sus riberas a las aves del cielo i sus aguas a los rayos sedientos del sol.

MEDICINA. Corias observaciones sobre la epidemia actual de sarampion i alfombrilla.-Comunicacion de don P. Zorrilla a la Faculiad de Medicina en una de las sesiones del presenle año.

En la época que atravesamos anormal bajo el punto de vista climarérico, mucho de nuestros pueblos están sufriendo el asote de las fiebres exantemáticas, viruela $\mathrm{i}$ alfombrilla. En Santiago el desarrollo de la última ha hecho innumerables victimas, cebándose sus malignos efectos con especialidad en la infancia. Este hecho que pasa a nuestra vista no tiene sin duda actualmente la importancia histórica que podrá tener para los tiempos venideros. Por eso es de suma necesidad sacar a la luz pública todas las observaciones que se presten a correlacionarse $i$ dar así orijen a saludables conclusiones médicas, relativas a las enfermedades de ncestra patria.

Las causas de estas epidemias en sus relaciones climatéricas i topográfica serán objeto, a lo que creo, de interesantes trabajos emprendidos por los amantés de la ciencia. Entretanto me limitaré a bosquejar los caracteres particulares de la epidemia de Sarampion que ha pesado sobre esta cindad.

El sarampion se puede considerar como enfermedad endémica en este lugar. Es mas comun encontrarla en primavera atacando de preferencia a los ninos, durante el primer período de la infancia: pero sigue su marcha comun, i termina bien i sin complicaciones, casi siempre. De modo que raras veces preocupa su presencia, $i$ los enfermos la sobrellevan en pié i sin mayores cuidados. Mas no ha sucedido de la misma manera en este último tiempo. A mediados de octubre del año 63 empezó a notarse su aparicion de un nodo epidémico. Bien pronto el número de los atacados por la enfermedad se hizo considerable, a punto que tan sola a la dispensaría de Yungai acudian diariamente de veinte a treinta, niños i adultos, pero mas 
OBSERVACIONES SOBYE EL SARAMPION T LA AIFOMBRILLA.

691

de los primeros: $\mathrm{i}$ entre los adaltos la proporcion de las mujeres respecto de los hombtes estaria de cuatro a uno.

En el hospital de San Borjas, que es de donde he tomado el mayor número de observaciones, una cuarta parte a lo menos de las concurrentes se presentaban atacadas de alfombrilla

Los síntomas con que ha aparecido esta enfermedad nada tienen de benignos, siendo por el contrario mui comun encontrarlos siguiendo una marcha anómala i acompañados de complicaciones mas o ménos graves cuyo asiento eran los principales ceatros del organismo, el cerebro, aparato respiratorio i tubo dijestivo.

Describiremos la marcha de este exantema cual se ha prèrentado a nuestra ubservacion, para hablar despues de las complicaciones que mal comunmente le han acompanado i mencionar algunos puntos de la descripcion que se hace ordinariamente de esta enfermedad a fin de que puedan notarse a primera vista las particularidatles de la epidemia que nos ocupa.

De los estadíos eu que se divide la marcha del sarampion, llamados incubacion, invasion, erupcion i descamasion; prescindiremos del primero que aparte de su vaguedad característica nada de particular ofreceria.

El segundo estadío, invasion, que comprende desde que se manifiestan los síntomas febriles hasta que aparece la erupcion, duta de tres a cuatro dias i casi nunca mas, dice Grisoll; ahora bien en esta epidemia ha oscilado entre cinco, ocho $i$ hasta doce dias, siendo la fiebre en este período mui intensa, pues ha resistido en atgunos casos con toda su enerjia a las depleciones sanguineas $i$ al empleo sostenido i enérjico de los demas antuflojisticos. Los sintomas catarrales eran mui intensos sobre todo por parte de las conjuntivas en la que he visto dos casos de equimosis subconjuntivales que ocupaba la totalidad de la mucosa que cubre la esclerótica.

Durante este período se han visto aparecer en los niños de tierna edad, convulsiones que podian tomarse por ataques de verdadera eclanopsia pero que terminaton felizmente.

El tercer estadio, erupcion que dura de dos a cratro dias, ha variado de uno a seis dias. En este período, los síntomas catarrales se han hecho mui predominantes; tos seca i ronca, dolor $\mathrm{i}$ opresion esternal, en algunos casos la inflamacion de la mueosa larinjea i traqueal i probablemente el desarroilo en ellas de la erupcion misma ocasionaba la ronquera i hasta verdadera afonía. Este estado se presentó en la mayoría le los casos: ademas la lengua está roja i seca, la inyeccion de las conjuntivas continúa, trai fuerte coriza i hemorrajias nasales abundantes.

La erupcion apareció en algunos casos tan confluente i roja que inducia

(*) Aqui se hecha de ménos de un modo mui notable la carencia de la estadistica medica del hospital: esa falta nos imposibilita para precisar el cálcuio. 
a creer en la existencia sinnultánea de lia escariatina, entre los que he observado el siguiente que no carece de interes, a mi ver; era una jóven de diez $\mathrm{i}$ ocho anos de redondeadas formas, $\mathrm{i}$ por consiguiente al parecer de constitucion robusta. Se nos presentó con una tumefaccion de la cara de un rojo oscuro que ocupaba las mejillas, nariz, párpados i parte inferior de la frente: se veian tambien ampollas cristalinas de dos a cuatro centinetros de estension, semejantes a las del psnfgo pero diferenciändose de estas en que no cambiaron su transparencia ni dejaron al desaparecer costras ni escoriacion alguna. El pulso mui desarrollado i frecuente, lengua roja i seca, respiracion anhelosa: se creyó era una erisipela flictennidea: a los dos dias siguientes se notaron en sus brazos i parte anterior del tórax, pequenas manchas irregulares, rojas, persistentes a la presion, a la par que manchas de un color rojo mas vivo, irregulares tambien i de cuatro a seis pulgadas de estension: aparece el dolor de garganta la fonacion se hace dificil, la lengua se pone fulijioosa, la inchazon de la cara avanza, invade al cuero cabelludo. en donde las ampoilas se multiplican, i sobreviene delirio: el pulso está frectente i pequeño, ciento veinte pulsaciones por miwuto, se teme la mnerte de la enferma. No obstante este cuadro amenazador los sintomas remiten gradualmente, las erupciones de alfombrilla i escarlatiniforme desaparecen al quinto dia de su nacimiento, sigue a estas la de la cabeza i la enferma se halla fuera de peligro a los toce dias.

El tratamicn to se compuso, de la aplicacion a la cabeza del hungüento mercurial $\mathrm{i}$ del empleo de los antiflojisticos $\mathrm{i}$ sedantes alternados con los antiespasmódicos $\mathrm{i}$ tónicos neurostẹnicos.

F.l cuarto estadio, descamacion; se ha prolongado igualmente mas de to ordinario alcanzando al décimo sesto $\mathrm{i}$ tlécimo octavo dia; $\mathrm{i}$ la fiebre qque jeneralmente disminuye $\mathrm{i}$ aun cesa en esta época ha persistido hasta despues de los veinte dias, lo que se debia comunmente a las complicaciones que continuaban su curso (").

Hasta aqui solo hemos tratado brevemente la marcha que ha seguido ei sarampion en la epidemia actual, considerándolo en su mayor simplicidad, desligado de las complicaciones propiamente dichas, de las que pasamos a hablar examitándolas en cada uno de los órganos en que se han presentado.

Cerebro:-Las afecciones cerebrules se han hecho mui frecuentes sobre todo en el tercer $i$ cuarto estadio. De estas las meninjitis o ineningoensefalitis atacando a niños, de corta edad han ocasionado la muerte de un gran número de ellos; st marcha era en la mayoría de los casos lenta

(*) Notemos de paso que las escamitas furfuraceas propias de la terminacion de esta enfermedad no las he visto sino en mui pocos casos, i mi colera i amigo don Damian Miquel, dice no hnberla visto, sino tres veces en un crecitisimo nuinero de enfermos asistidios por el el su prática particulyr i en la dispensaria de Yungui 
OBSERVACIONES SOBRE EL SARAJIPION I LA ALFOMBRILLA. 693

pero funesta. Despues de entrar en el periodo de convalescencia se apodera de los niños un aparato febril poco intenso, o por que aumenta paulatinamente hasta dejenerar en verdadero coma: siguese a este movi miento desordenato, accesos convuisivos, poco frecuentes, pupila dilatada, pulso pequeño, relajacion muscular, respiracion dificultosa, etc.: por úlimo prolongándose este estado no tarda en acarrear la muerte de los enfermitos

Los síntomas que anteceden revelan a no dudarlo una inflamacion lenta de las meninjes i cerebro a la que sigue un derrame ceroso sub-aragnoi_ deo: lesiones que esplicau suficientemente la causa de la mucrte.

El caso que sigue me ha sido comunicalo por don Damian Miquel quien lo observó en la dispensaría de Y ungai: una ninita de cuatro años fué atacada de sarampion: en el tercer períodu, cuando la erupcion estaba en su mayor desarrollo, sobrevinieron diarreas sanguinolentas mui abundantes: sometida a un tratamiento, adecuando las deposiciones tomaron un aspecto natural $\mathrm{i}$ disminuyeron notablemente de frecuencia.

Al dia siguiente de esta mejoria fué acometida de vómitos biliosos mui abundantes i rebeldes, que duraron desde lis doce hasta las seis i media de la tarde, hora en que fueron reemplazados por movimientos convulsivos epileptiformes, terribles, los cuales cesaron solo con la muerte a las seis tres cuartos. La autopsia ne se pudo practicar por la preocupacion de su padres.

Eil los adultos hemos visto igralmente despertase compromisos cerebrales, conjestiones, meniujitis etc.; pero terminando las mas veces de un modo favorable.

Aparato respiratorio.-De todas las complicaciones a que ha dado lugar el sarampion, la inflamacion del arbol aéreo $i$ aun del parénquima pulmonar, ha sido sin disputa la mas comun i funesta.

La bronquítis en los niños que lactaban todavia, iavadiendo las ramificaciones bronquiales pequeñas era seguida de un catarro sofocativo que ofrecia tantos o mayores riesgos que la inflamacion del parénquima pulmonar mismo. Al principio del tercer estadio manifiesta el niño grande opresion al pecho que se hace ostensible por la dificultad de respirar, a veces vertladera ortonea: a la auscultacion, el ruido vesicular aparece mui débil o falta del todo, i en algunos puntos se notan ruidos sibilantes: tales cambios producen la asfixia en los niños de pocos meses, mucho antes que el estado inflamatoria liegue al periodo de coccion.

En los adultos la bronquítis se ha hecho mui duradera; siguiendo en unos un curso crónico i desarrollando en muchas mujeres los tubérculos pulmonares, cuya consecuencia mas comun ha sido la muerte; $i$ en otros una marcha agudísima que no ha tardado en provocar ei desarrollo de la pulmonia.

A la par que ia mucosa bronquial las auditiva i larinjea lian sido el 
asiento de inllamacion aguda i crónica: la otitis sobre todo no la dejado de presentarse casi en uinguna de las mujeres que hemos visto atacadas por esta fiebre. En el período de erupcion empezaba la voz a debilitarse $i$ en dos o tres dias las enfermas quedaban realmente afónicas. La perturbacion del oilo aparecia en el último estadio, i llegaba a ser total la pérdida de este sentido (cophósis): ciesórcien que persistia hasta aigun tiempo dcspues de haber desaparecido la enfermedad principal.

Tubo dijestico. - No es por cierto la mucosa dijestiva la que ménos ha dado orijen a trastornos que conplicaran la enfermedad de que se trata.

Debemos mencionar en este sitio las enterorrajias i mas especialmente la enterítis; seguidas de ta diarrea que prolongándose por muchas semanas, despues de la conralecencia estenúan al enfermo $i$ hacen su restablecimiento tardio i penoso. En estos casos se han encontrado con frecuencra ulceraciones de la mucosa en el intestino delgado.

He aquí este corto relato de los caracteres principales que ha revestido la epidemia de sarampion, que aun no abandona del todo a esta ciudad, i sobre la cual debemos esperar se hagan estudios mas prolijos.

FILOSOFI9, I DERECHO NATURAL.-Programas universitarios para el estudio i exámenes de estos ramos, segun los textos actualmenie aloptados.

I.

FILOSOFIA.

PRELIMINARES.

Qué es Filosofia:-Su objeto i medios de conseguirlo.-p. 10.

Litilidad e importancia de esta ciencia. $\rightarrow 3$.

Su division en cuatro partes.-p. 9.

\section{Psycolojía.}

Qué es Psycolojia?-Su division.-p. 2.

Objeto propio de esta ciencia; su díferencia de la Fisiolojia.-p. 14.

Posibilitad de la observacion por la conciencia.-p. 14.

Carácter de la certidumbre que nace de los hechos de la conciencia.p. 16.

Necesidad de principias por la Psycolojía el estudio de la ciencia filosétca.-p. 16.

Pensamiento; fenómenos que en él intervienen.-p. 17.

Clasificacion de estos fenómenos.-id.

Causa eficiente $i$ cansa ocasicnal Lel pensaniento.-p. 18 . 


\section{CÓMO SE EVITA EL CÓLERA: \\ ESTUDIO DE HIJIENE POPULAR ${ }^{18}$}

Documento publicado en 1886 por Federico Puga Borne (1855-1935), médico, profesor y político chileno, reconocido en el campo de la medicina por sus aportes a la farmacopea y por sus nombramientos como director del Museo de Historia Natural de Valparaíso en 1878 y como director del Instituto de Higiene del país en 1892.

En este texto instala una voz de alerta ante la proximidad del cólera al territorio nacional, y enfatizó en la necesidad e importancia de tomar medidas preventivas dado que dicha enfermedad afectaba a la nación argentina. Realiza una acuciosa descripción de los conocimientos científicos y las incertidumbres aún presentes respecto de las causas y formas de propagación de la enfermedad, e incorpora una narrativa histórica para fortalecer el argumento de que eran las medidas de precaución las que podían evitar que la enfermedad afectase al país. En específico, discute que Chile tendría características naturales que le harían inmune a la propagación de la enfermedad, pero su conclusión es que no existían argumentos para asegurar que el país no sería tocado por el mal, como de hecho ocurrió dramáticamente a partir de ese año, en el que la epidemia del cólera se extendió por todo el territorio y tras la cual se creó la Junta General de Salubridad, fundada en 1887.

En este llamado de atención indica las medidas que consideraba acertadas para prevenir la enfermedad y destaca, en primer lugar, el cierre de fronteras, y describe y explica las medidas de higiene necesarias para evitar la diseminación de la enfermedad: el aislamiento de los casos, el lavado de manos, la instrucción de la ciudadanía acerca de las medidas de prevención, la prohibición de grandes reuniones de personas y la creación de una infraestructura pública de salud de manera anticipada para enfrentar la enfermedad. Las medidas públicas y privadas aconsejadas por el doctor Puga remueven por su actualidad y contingencia.

18. Puga Borne, Federico. Cómo se evita el cólera: estudio de higiene popular, Santiago, Imprenta Nacional, 1886. Biblioteca Nacional de Chile. Disponible en: http://www.memoriachilena.gob.cl/ 


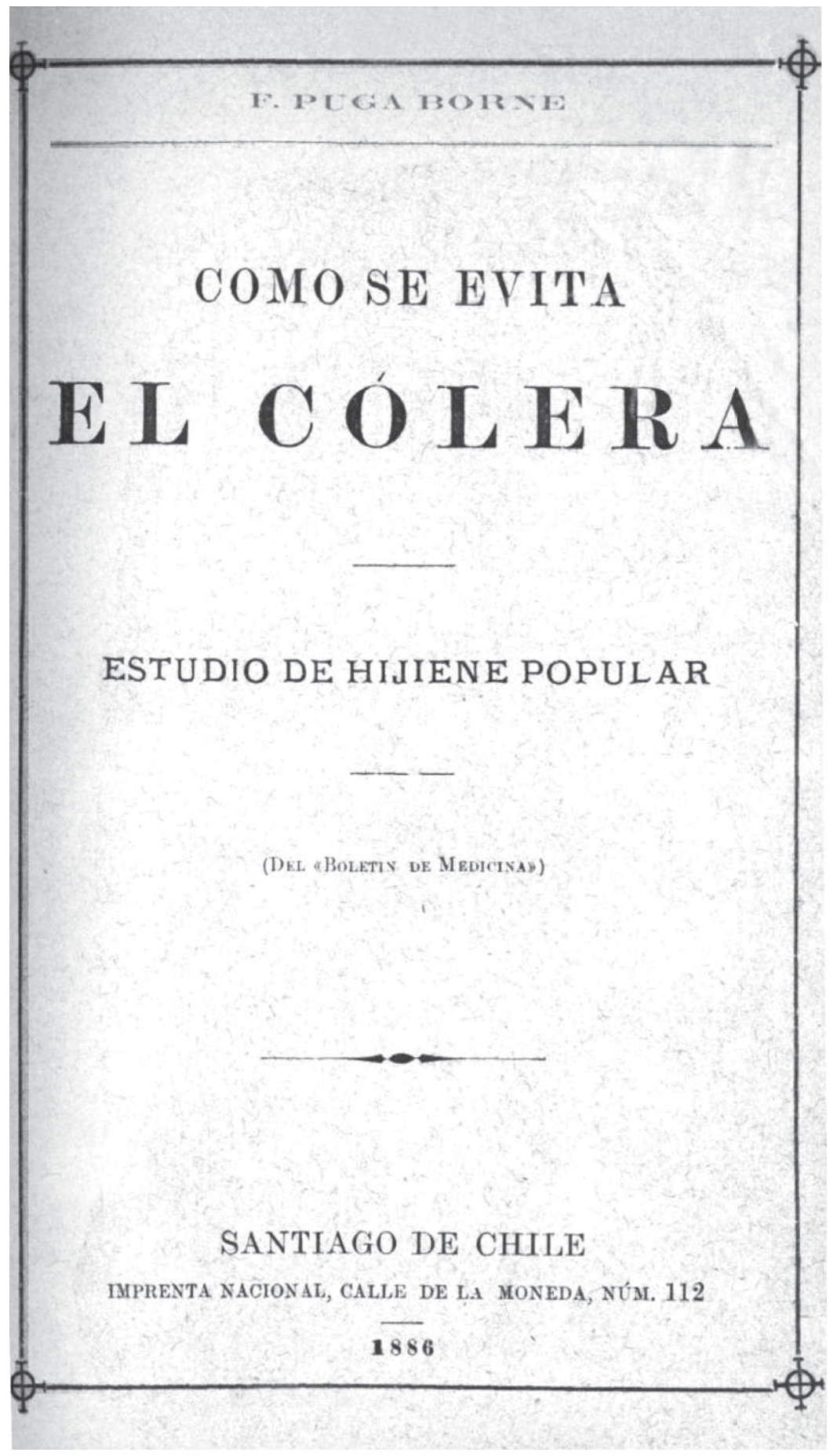




\section{COMO SE EVITA}

\section{E L C Ó L E R A}

ESTUDIO DE HIJIENE POPULAR

(Dri «Bolftix de Medicisa»)

SANTIAGO DE CHILE

IMPRENTA NACIONAL, CALLE DE LA MONEDA, NÚM. 112

$\overline{1886}$ 


\section{HIJIENE IEL CÓLERA}

\section{Instruccion popular para los chilenos}

Una de las enfermedades mas tremendas que aquejan a la especie humana, se halla a pocas jornadas de nuestras poblaciones. El cólera asuítico, índico, maligno o epidémico, la formidable peste azul del oriente es hoi el huésped de nuestros vecinos del Plata. Este hecho impone a todos los chilenos el deber de prestar atencion a los progresos de la epidemia $\mathrm{i}$ de apercibirse al mismo tiempo para el caso de que llegue a penetrar en nuestro territorio.

No es una timidez injustificable sino una prudencia fria, nacida del conocimiento del peligro, lo que nos ha arrastrado a dar esta voz de alarma, desde hace ya muchos dias, desde el 28 de noviembre en que bajo el título de "Chile i el cólera» publicamos un estudio en el diario La Época.

Ciertamente que ante la espectativa de un peligro semejante hai que evitar el estremo de cautela que lleva al pánico; pero no es ménos preciso evitar el estremo opuesto, el de la confianza que lleva a la inaccion.

Una de las cualidades del hombre en que se revela mas patentemente su superioridad es la prevision; i jamás esta prevision es mas noble i mas fecunda que cuando se aplica a resguardar a una sociedad entera de un peligro de muerte.

Cuando se trata de prevenir tamaños males, nunca están de mas las precauciones, los consejos, los desembolsos.

Aquella inclinacion tan jeneral a creer siempre lo que se desea es la que inspira esas reflexiones tranquilizadoras de: todavía no hai peligro, las precauciones son supérfluas, la epidemia es un fantasma; esa misma es la que induce a engañarse sobre la naturaleza 
de los primeros casos de cólera que aparecen en cada pueblo, haciéndolos tomar como enfermedades inocentes; finalmente, esa misma inclinacion es la que induce a disimular siempre los estragos de la epidemia.

Ese sistema es el que trae consigo la indiferencia cuando el enemigo está léjos, el anonadamiento cuando está encima.

$\mathrm{Si}$ en nuestra época el cólera es algunas veces contenido, si se logra impedir que entre en un pueblo, si se logra que aborte así que ha penetrado, no se debe considerar tal resultado como una casualidad sino como un triunfo de la prevision humana, no como una salvacion a que teníamos derecho sino como una derrota del enemigo a quien no se aguarda desarmado.

Un hombre que es la personificacion mas elevada del jenio científico de este siglo XIX, Pasteur, ha dicho: «cuando se contemplan los espantosos males que las enfermedades contajiosas causan en el mundo, es consolador el observar que la existencia de estas enfermedades no tiene nada de necesario.» Pasteur abriga firme confianza en la estincion de estas plagas, i con respecto al carbunclo, por ejemplo, espera el dia en que sea enteramente desconocido para el hombre. Pero no se obtendrá semejante resultado sino en virtud de una lucha constante, no se obtendrá sino cunndo la fé en la ciencia impere en el espíritu de los gobiernos.

La esperiencia ha demostrado que el cólera no se enseñorea sino en los pueblos que encuentra desprevenidos o atemorizados; por lo tanto, es necesario precaverse de este enemigo con anticipacion i a sangre fria.

\section{NATURALEZA DEL CÓLERA}

La causa esencial del cólera aunque mui dilucidada no está bien determinada todavía a pesar de las investigaciones sábias, perseverantes $\mathrm{i}$ hasta heróicas de que ha sido objeto últimamente. La teoria mas razonable, como es la que cuenta en su abono con mas hechos ciertos i la que mas fenómenos esplica, es aquella que creada al parecer por Budd, ha recibido casi completa confirmacion con las esperiencias i observaciones de Thiersch, Sanderson, Koch, Nicati i Rietsch, Cantani, Van Enmergen, etc. Admite que el jérmen del cólera es un organismo microscópico parasitario, un mibrobio; admite ademas que la rejeneracion del veneno coleríjeno tiene lugar no en el cuerpo del hombre sino fuera de él, en un medio putrefacto, lo que no impide sin embargo que sus focos sean 
trasportados a distancia por el hombre, las bestias i los vehículos. El ajente parece no ser otra cosa que una sustancia producida por los indicados organismos microscópicos vivos, la cual, análoga a las ponzoñas, obraria como un fermento de secrecion, como una de esas sustancias particulares que en el dia se están descubriendo i estudiando bajo el nombre de sepsinas, cadaverinas, tomainas i leucomainas.

El cólera no es por consiguiente contajioso en la acepcion estricta de esta voz, es decir, no se trasmite por contacto directo del hombre enfermo al hombre sano; pero sí, infecto-contajioso en el sentido de trasmitirse al hombre sano por la accion de ciertos productos del enfermo que han esperimentado una trasformacion especial fuera de su cuerpo. El organismo humano no reproduce entónces el veneno, produce solo un ajente que es susceptible de convertirse en veneno con tal que se encuentre en ciertas condiciones.

Esta necesidad de un medio doble, propia del jérmen colerijeno, es la que justifica en muchos casos la creencia en el desarrollo autóctono del mal, es decir, en su nacimiento espontáneo fuera de la rejion jeográfica que hasta ahora ha pasado por su única cuna, la hoya del Ganjes.

Sin embargo, tambien hai motivos para creer posible el que la sustancia tóxica, cuya absorción i penetracion en la sangre causa el cólera, sea formada dentro del intestino mismo del hombre por la actividad vital del microbio coleríjeno.

Debemos confiar en que los estudios perseverantes de Koch, Pasteur i sus discípulos han de acabar por revelarnos el secreto de este misterioso ajente que ha venido a desempeñar en la historia de la humanidad el mismo papel que la gota, la lepra, la peste, el escorbuto i la viruela, plagas que sucesivamente han venido diezmándola.

Que el cólera es una enfermedad parasitaria, microbial, no admite duda; cual sea su parásito o microbio es lo que no está determinado todavía con certidumbre.

Koch concluye de sus investigaciones que «el cólera es la enfermedad del bacilo vírgula o coma, i que este nunca falta en dicha enfermedad, siendo su característica específica.» Pero esta teoría no ha recibido aun la confirmacion esperimental rigorosa que la ciencia exije para considerar como hecho positivo el de que tal microbio es el causante de tal enfermedad. 


\section{¿PUEDE ENTRAR A CHILE EL CÓlera?}

Para resolver esta cuestion ha de tenerse presente el orijen del veneno colerijeno i el modo como acostumbra estenderse.

Nacido en el Indostan, a las orillas del Ganjes, donde su actividad es permanente i da lugar a casos endémicos de enfermedad que por un aumento estraordinario de frecuencia pasan a constituir epidemias $\mathrm{i}$ aun pandemias (enfermedades que atacan a la mayor parte o a la totalidad de los habitantes de un pais), puede difundir su accion hasta los puntos mas lejanos de la tierra, sirviéndose para ello como de un vehículo de los cuerpos humanos o de los objetos que estos acarrean.

Tres son los grandes ajentes de esta diseminacion por el hombre: la guerra, el comercio i la relijion; el último, por medio de las peregrinaciones que verifican periódicamente de la Arabia al Ganjes innumerables caravanas de mahometanos, es el que con mas frecuencia acerca el cólera a Europa; los dos primeros son los que se encargan en seguida de distribuirlo a todo el mundo.

Conocida por los médicos europeos de un siglo a esta parte solamente (1781 Ganjam, costa del Malabar) ha hecho en tan breve espacio cuatro grandes invasiones en casi todo el antiguo continente, gran parte de la Oceanía i en ambas Américas, esceptuando la costa del Pacífico al sur de Panamá. Cada una de estas grandes escursiones emplea algunos años, pnes deja en los lugares que invade focos mal apagados que renacen varios años seguidos; de manera que se considera haber sido solo cuatro las grandes epidemias anteriores a la actual. Estas han comenzado en Europa los años 1817, 1830, 1847 i 1865. Algunas han tenido una duracion que pasaba de 15 años.

La primera se detuvo en las puertas de Europa, en Rusia, despues de atacar toda el Asia i las islas Filipinas.

La segunde, despues de invadir la Europa, atravesó el Atlántico i puso el pié en América llevada al Canadá en junio de 1832 por inmigrantes irlandeses. Esta, que fué para Europa la primera invasion, durante cuatro meses del año 1831 atacó a 335,000 personas de las cuales 151,000, casi la mitad, murieron.

Tercera epidemia. La Europa habia pasado once años libre del cólera cuando en 1847 las caravanas de peregrinos de la Meca motivaron la comunicacion de un redoblamiento de la epidemia que desde $18+4$ allijia al Indostan. Esta pasó con buques de enigran 
tes a Nueva York en diciembre de 1848; de allí se estendió por el Pacífico a las Antillas i Rio Janeiro; por Nueva Orleans al Atlántico, devastando los puertos de California i la América Central; se ha creido posible ademas en esta ocasion la llevada del cólera directamente del Asia a San Francisco. No desapareció de Europa sino en 1862.

La cuarta epidemia (1865) estallô en Suez el 19 de mayo, dos dias despues de haber hecho escala en su puerto el trasporte Sidney que habia embarcado en Djeddah 2,000 peregrinos, de los cuales algunos, muertos durante lá travesía, habian sido echados al mar.

Su estension fué tan rápida como devastadora: en menos de tres meses mató mas de 60,000 ejipcios.

El 11 de junio estaba en Alejandría, el 24 de julio en Marsella, llevado por 67 peregrinos en La Stella, el 18 de setiembre en Paris, donde desapareció con los frios de enero para resucitar en los tres veranos siguientes, estendiéndose cada vez mas. Se estinguió definitivamente en Paris a tines del otoño de 1867.

En febrero del mismo año 67 estaba en Rio Janeiro i aunque no se determinó precisamente el ajente introductor, todos admiten que era propagada de Liverpool a Jénova i no nacida espontáneamente; declaróse en Montevideo, en el ejército alia.lo contra el Paraguai i en Buenos Aires; se apagó en mayo; reapareció en setiembre i se internó con los fujitivos al interior hasta Mendoza; el invierno le puso término. En Rio Janeiro no ha desaparecido aun del todo i ofrece cierto carácter endémico; algo semejante debe haber pasado en las orillas del Plata, pues en el verano de 1873 a 1S74 hubo una pequeña epidemia que penetró hasta Villa Mercedes i Rio Cuarto.

Como una sola epidemia que vendria a ser la quinta deben considerarse los casos de cólera ocurridos en Ejipto i Europa en los cuatro últimos años. Estalló en Damieta el 25 de junio de 1883 despues de recibirse sin visita el vapor Timor de las Indias i de llegar algunos comerciantes de Bombay a una feria celebrada cerca de Damieta. Alcanzó a producir 200 muertos por dia; se calcula en 40;000 el número total de defunciones ocurridas en Ejipto; las medidas tomadas para atacarlo fueron estremas, entre otras la destruccion por el fuego de barrios enteros.

Bien conocida es la penetracion del mal en el sur de Francia en el verano de 1884 i su propagacion a la Italia i la España, como tambien la amenaza que hizo a la América del Sur. Conociendo la 
marcha que han seguido las epidemias anteriores no era aventurada la sospecha de que la estincion de esta epidemia no habia de ser sino pasajera, debiéndose por tanto esperar su reaparicion en el hemisferio norte para el año siguiente. El hecho ha confirmado aquel anuncio: durante la estacion ardiente de 1885 devastó la España con una violencia inolvidable haciendo 120,000 muertes; en el año actua ataca a la Hungría, la Italia i pasa a la América del Sur.

Al mismo tiempo asola algunas ciudades del Japon, pues segun noticia dada por el Times de Lóndres, a principios de setiembre hacia mas de mil víctimas por dia.

La mortalidad causada por estas epidemias en algunas poblaciones ha sido verdaderamente horrenda: de cada 1,000 habitantes murieron 100 en Alepo el año 1865; 149 en Guadalupe el año 1856; 200 en Küsscamp el año 1859. En algunos cuerpos del ejército de la India la mortalidad ha sido aun mayor.

Pocas han sido, pues, las épocas en que una verdadera epidemia de cólera asiático se ha aproximado a Chile.

La primera cuando despues de recorrer el Asia, la Europa i los Estados Unidos llegó por la costa del Pacífico hasta Panamá a fines de 1852. En 1867 la segunda, en 1873 la tercera por la epidemia reducida a Buenos Aires, i finalmente la actual. De todas éstas la amenaza mas séria fué la de 1867 en que el cólera invadió gran parte de la hoya del Plata entre febrero i marzo; con los frios se estinguió para reaparecer en setiembre en Buenos Aires; reinó en este puerto hasta febrero haciendo numerosas víctimas tanto en él como en el ejército aliado contra el Paraguai. De este foco se repartió en todos sentidos hasta llegar a Catamarca i Mendoza. Es de notar que estas dos ciudades i las demas que fueron atacadas, Córdoba, el Rosario, San Juan, no recibieron el azote sino despues de haber desaparecido de Buenos Aires. En Mendoza no apareció tampoco sino despues de que las autoridades de San Juan, apoyadas en la opinion del cuerpo médico, habian declarado estinguido en ese punto el cólera. Por eso sucedió que el gobierno de Chile apenas suprimió en vista de esa declaracion el cordon sanitario, se vió en la necesidad de restablecerlo.

En la ciudad de Córdoba, cuya poblacion qued6 reducida por la fuga a solo 12,000 habitantes, las defunciones diarias llegaron a trescientas.

Lamentables estragos hizo en las ciudades arjentinas i mucho mayores en sus campos aquella epidemia, i su no penetracion en 
Chile es imposible de atribuir a ótras causas que a la interrupcion del comercio que se decretó $\mathrm{i}$ a las nevazones precoces que ese año obstruyeron por completo los pasos de la cordillera desde el mes de marzo.

Hoi que por los ferrocarriles las comunicaciones a traves de las pampas son mas rápidas, la aparicion del cólera en Buenos Aires representa para nosotros un peligro mas inminente, i mucho mayor todavía su aparicion al principio de la estacion caliente, pues si toma cuerpo no vendrán los frios del invierno a aplacarla sino de aquí a cuatro o seis meses, ni la obliteracion de los pasos de la cordillera podrá venir a valernos esta vez.

Por lo visto no es la naturaleza la que hasta ahora nos ha salvado del cólera sino la adopcion de precauciones artificiales i una circunstancia, aunque natural, fortuita. ¿Qué podria valernos en adelante? En otros términos: ${ }_{i}$ Hai en la naturaleza de nuestro territorio causas suficientes de inmunidad contra el cólera?

Pasemos a examinar las que con mas o menos fundamento podrian mirarse como tales: la temperatura relativamente baja de nuestro clima, la elevacion sobre el nivel del mar de nuestro temitorio, la constitucion jeolíica del suelo, la sequedad atmosférica, la considerable latitud de parte del territorio, la presencia de la altísima cordillera de los Andes $i$ la gran distancia a que estamos del teatro ordinario del cólera.

La primera es completamente ilusoria. En efecto, el pueblo de temperatura mas baja talvez de Chile, Punta Arenas, que tiene $7^{\circ} 2$ de temperatura media anual, es mas caliente que varias ciudades europeas que han sido asoladas por el cólera. San Petersburgo invadido por primera vez en 1831 tiene solo $3^{\circ} 5$ de temperatura media. Stokolmo, Varsovia i Berlin que han sido tambien sus víctimas, $5^{\circ}, 7^{\circ}$ i $8^{\circ}$ respectivamente. Hasta ahora el límite norte que han encontrado sus invasiones epidémicas está mas allá de la isoterma $0^{\circ}$. Valparaiso no es mucho mas frio que San Francisco de California, pues tiene $14^{\circ}$ mientras aquel tiene $15^{\circ}$. Santiago casi llega a 13 i Buenos Aires a 17. En estos dos pueblos sucede ademas que la época en que se exacerba el cólera, el verano, las temperaturas se aproximan notablemente. Santiago llega entónces a $32^{\circ} 9$, Buenos Aires a $35^{\circ} 6$ i San Petersburgo a $33^{\circ} 4$.

Es cierto que el frio del invierno parece estinguir las epidemias, pero es solo adormeciéndolas como lo manifiesta el caso del mismo San Petersburgo: apesar de tener esta ciudad en el invierno el espantoso frio que revela un descenso del termómetro a $34^{\circ}$ bajo cero, 
fué sin embargo la última de Europa abandonada por la epidemia del 48, pues se vieron en ella algunos casos de cólera hasta 1862. En el invierno de 1830 reinó el cólera en Moscow, causando muchas víctimas en los hospitales a una temperatura de $20^{\circ}$ bajo cero.

.En cuanto a la altura sobre el mar podria creerse que algunos pueblos de Chile, sobre todo de la parte norte del valle central, por estar a cierta elevacion, podrian gozar de la misma inmunidad de que han gozado algunas rejiones que, aunque estrechamente sitiadas por el cólera, no han sido invadidas. Están en este caso la Suiza Alpina, los Pirineos, la Moravia, la Silesia i la meseta central de Francia. En este último pais se ha calculado que la altura media de los distritos respetados por el cólera es la de 320 metros i 113 la de los atacados.

Pero esta no es una ventaja con la que pudiera contarse ciegamente ni que haria tampoco participar de sus beneficios a la totalidad del pais.

Baste considerar que entre todos los pueblos de alguna importancia situados en el valle central de Chile es Santiago el mas elevado. Comparando su altura sobre el nivel del mar, que es de 569 metros, con la de las ciudades arjentinas que devastó el cólera en 1868, se verá que es inferior a varias de ellas. Así miéntras Córdoba tiene una altura de 416 metros i Catamarca una de 531, Mendoza tiene 677 i San Juan 704. (Martin de Moussy, Atlas de la «Descripcion jeográfica $i$ estadística de la Confederacion Arjentina» publicada en 1873.)

En realidad, parece que el cólera ha traspasado una elevacion mayor que la de nuestros pueblos: en la cadena del Nepal se citan puntos atacados que tienen unos 1,400 metros ( 5,000 piés ingleses). En Méjico i en el Cáucaso se ha visto reinar el cólera a una altura de 2,000 i 2,300 metros; como se le ha visto tambien en la meseta que separa a Chiraz de Ispahan cuya altura es de 2,000 metros o sea 7,000 piés (Proust).

San José de Maipo con 1,000 metros, San Felipe con 657 i Santa Rosa de los Andes con 769 serian los pueblos que estarian mejor colocados a este respecto.

La presencia de la cordillera de los Andes no seria barrera contra el cólera sino en el sentido de la dificultad que impone a las corrientes humanas. Su simple elevacion, por grande que sea, no la constituye en manera alguna obstáculo suficiente para el paso de los jérmenes del mal. Lo seria talvez en caso de que el cólera 
tuviera necesidad de reproducirse en sus heladas alturas para llegar hasta nosotros; pero no desde que solo se trata del viaje de individuos ya enférmos que traerán el mal confirmado o solamente los jérmenes en incubacion para venir a desarrollarse despues de terminado el viaje. Recuérdese que aun cuando el período de incubacion (durante el cual el individuo se halla aparentemente sano) es por lo jeneral mas breve, de 1 a 7 dias, puede durar hasta 22, i que el yiaje desde la otra banda solo dura 4 i desde la misma Buenos Aires 5 (1).

Ni hai necesidad tampoco, hablando estrictamente, de que sea un cuerpo humano contaminado el que nos traiga el formidable jérmen: un vestido manchado por deyecciones coléricas, un otro objeto material cualquiera nos lo puede traer en muchas circunstancias sin que haya perdido nada de su poder.

La esperiencia ha probado ademas que las cadenas de montañas no son para el cólera barreras insalvables: en 1827 atravesó el $\mathrm{Hi}$ malaya pasando de la India al Asia Central i en 1830 el Cáucaso pasando de la Persia a Europa.

La sequedad atmosférica que en nuestro clima es verdaderamente bien notable, constituiria una circunstancia mui desfavorable para la propagacion del cólera, pues sus estragos siempre parecen guardar proporcion con la humedad del aire; esta seria una considerable ventaja para los pueblos chilenos situados lejos del mar.

Koch ha observado que el bacilo vírgula muere rápidamente en cuanto se deseca.

La latitud o distancia del Ecuador verdaderamente considerable en que se encuentran nuestras provincias meridionales, no constituye en manera alguna preservativo del cólera. La epidemia ha llegado en el hemisferio norte hasta Arcánjel que tiene una latitud superior a $70^{\circ}$, al paso que la estremidad meridional del continente americano llega apénas a $56^{\circ}$.

(1) Eichorst en el «Diccionario enciclopédico de Medicina i Cirujía prácticas», escrito en aleman bajo la direccion del Dr. Eulenburg, rejistra el cuadro siguiente sobre la duracion de la incubacion tomada con exactitud en 64 casos que ocurrieron en la aldea de Bourg de Conie en el otoño de 1865 :

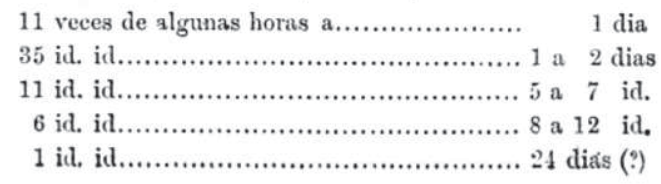


Sobre lo que sí ejerce real influencia la latitud, es sobre la forma de la epidemia: en las rejiones ecuatoriales son breves i violentas; en las rejiones distantes, como la Rusia setentrional i la Escandinavia, no atacan a tantos individuos pero tardan mucho en despẹdirse; hasta siete años seguidos se han visto casos en el mismo punto.

Lo mui apartado que se halla Chile del resto del mundo constituye evidentemente una ventaja en la materia de que tratamos. En la navegacion universal nuestros puertos son rara vez una estacion de tránsito; casi no tenemos que recibir sino las embarcaciones cuyo viaje termina aquí. Esto disminuye naturalmente las probabilidades de importacion del mal. Pero de esto no pasa la ventaja. La simple duración del viaje por larga que sea, no obsta a que un buque salido de un punto infestado del Asia o de Europa pueda desembarcar en nuestras playas el mal. Puede el buque salir con patente limpia trayendo dentro del cuerpo de un pasajero el cólera en incubacion, o en vestidos manchados la semilla morbítica. La enfermedad desarrollada así en el buque, puede irse trasmitiendo de hombre a hombre hasta el fin del viaje para comunicarse entónces a tierra. La observacion ha manifestado la posibilidad de estas trasmisiones directas a larga distancia: la aparición, por ejemplo, del cólera en Inglaterra el año 1832 ántes que en Francia.

Atendiendo a la composicion del suelo, sí que puede halagarnos la esperanza de que, a lo ménos en ciertas rejiones, nuestro Chile no sea un campo apropiado para el cólera. Una comision bávara, cuyos trabajos dirijió Pettenkofer durante la epidemia de 1854, estableció la lei, consagrada despues por la esperiencia, de que todas las localidades donde el cólera se encarniza epidémicamente, reposan sobre un suelo poroso, permeable al aire i al agua; i que, al contrario, en todos los puntos aun vecinos a los primeros, cuyo suelo o subsuelo está compuesto de rocas o piedias compactas, no se han visto aparecer sino casos esporádicos o sea aislados. Segun esto, para la reproduccion del veneno coleríjeno es indispensable la presencia de una capa de agua subterránea a $\operatorname{los} 2$ o 6 metros de profundidad i siempre sus cambios de nivel guardan relacion con las oscilaciones de intensidad de la epidemia.

Los terrenos de cristalizacion i sobre todo los graníticos, por lo compactos e impermeables, disfrutan de una inmunidad notable de la que se tienen muchos ejemplos: v. g., la ciudad de Lyon i seis departamentos contiguos del centro de la Francia, las pobla- 
ciones de Inglaterra edificadas sobre formaciones carboníferas encajadas en el granito, etc.

Es en las materias orgánicas que impregnan el suelo i que habitualmente quedan sumerjidas en la capa de agua subterránea donde duerme en estado de vida latente el jérmen del cólera para prosperar tan pronto como un descenso de ese nivel la deje en contacto del aire que necesita para verificar sus trasformaciones i tomar desarrollo.

Ahora bien, aunque el mayor número de las ciudades de Chile están edificadas sobre terrenos sedimentarios o de acarreo, porosos i con una capa de agua a poca profundidad, no faltan pueblos edificados sobre rocas que forman parte de la cordillera de la costa, constituida toda, como se sabe, por rocas graníticas. Muchas aun de las ciudades del valle central se hallan sobre rocas derivadas de aquellas i que hasta cierto punto participan de sus cualidades. A todas estas ciudades i en jeneral a todas las habitaciones que se hallan en igual caso es a las que sin duda favorecerá la inmunidad para el cólera a que se ha hecho referencia.

Hecho curioso; de ios vejetales que pueblan nuestro territorio hai uno, quizás el mas notable, que tiene la particularidad de no nacer sino sobre el suelo granítico: es nuestra palma de espléndida belleza; segun lo espuesto, la presencia de este árbol podria mirarse como una presuncion de inmunidad para el lugar.

Resulta, pues, de todo lo dicho que aun cuando gozamos en Chile de condiciones relativamente favorables desde que el cólera, para llegar hasta nosotros, tendria sus dificultades que vencer, no conocemos sin embargo obstáculo natural ninguno para la introduccion i propagacion de aquella peste.

La Facultad de Medicina de nuestra Universidad, despues de una deliberacion detenida, adoptó por unanimidad, en sesion de 14 de diciembre de 1884, las siguientes proposiciones:

No hai imposibilidad para que el cólera penetre i se propague en Chile.

El mejor preservativo de su introduccion es el aislamiento obtenido por la incomunicacion completa con todos los lugares infestados.

La misma corporacion acordó espresar como un deseo el voto siguiente:

«Es menester que se establezca en toda la República un servicio sanitario permanente.»

En las circunstancias actuales, con el cólera incipiente en la Re- 
pública Arjentina, con el conocimiento del carácter invasor que han tomado sus epidemias todas, con la frecuencia creciente de comunicaciones entre nuestro pais i el estranjero i con la estacion en que ha nacido allende los Andes, la indiferencia o la confianza por parte de los chilenos seria peligrosísima.

Es posible i es probable que la República Arjentina nos comunique hoi el cólera.

I si nos lo comunica, :ai! de nosotros. La ignorancia, la imprevision i la desidia que caracterizan a la mayoría de nuestra poblacion, la falta de salubridad en las habitaciones, el desprecio de los preceptos hijiénicos, la carencia de un servicio de salud pública, todos los caracteres de nuestro pueblo harian de él la mas fácil presa del cólera.

¿CÓMO, I POR DÓNDE PODRIA VERIFICARSE LA INTRODUCCION DEL CÓLERA EN CHILE⿰彳

La marcha de Este a Oeste que presenta la actual epidemia induce a dirijir toda la atencion hacia el lado del Oriente, tanto por las vias terrestres de comunicacion como por las marítimas.

El trasporte por mar del jérmen morbífico puede hacerse en las naves que pasan el Estrecho o doblan el Cabo viniendo de los puertos europeos infestados o de los puertos americanos del Atlántico, cuya infeccion ya está consumada; raro seria que el mal siguiera primero el camino de tierra hasta llegar al Pacífico i poder venirnos del norte en las embarcaciones, como lo seria tambien el que nos viniese directamente desde el Asia por la via marítima.

Por tierra, como ya se ha manifestado, no seria en manera alguna obstáculo suficiente para su paso la gran elevacion de la cordillera de los Andes.

Ya que la epidemia ha prendido en Buenos Aires, el Rosario, Córdoba i Mendoza, no seria tampoco motivo para sorprendernos el verla saltar hasta Santiago sin posesionarse de los puntos intermedios; en otros términos, para que aparezca en Santiago no es necesario que ántes venga prendiendo en cada uno de los puntos del camino.

Es un hecho de observacion el de que en cada pais son los grandes centros de poblacion los infestados primero, i ellos a su turno los que irradian sobre los pequeños pueblos circunvecinos. Esto se comprende fácilmente, en razon de la mayor frecuencia de comunicaciones que tiene lugar con la metrópoli. 
Tampoco seria de estrañar el que apareciera en los pueblos de Chile cuando ya se hubiera estinguido en los arjentinos; sabemos que así precisamente fué como avanzó la epidemia del 67 en los pueblos arjentinos: cuando parecia haber cesado en uno brotaba en otro de mas al occidente.

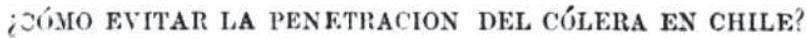

-No existe sino un medio práctico de lograr casi con plena seguridad ese fin: es el que ha adoptado nuestro Gobierno el 4 de Diciembre cerrando a las procedencias arjentinas todos los pasos de la cordillera i todos los puertos de mar.

Puede afirmarse con toda certidumbre que mientras no sea bur. lada esta medida el cólera no entrará a Chile. Por una tortuna escepcional la topografía de nuestro territorio nos da posibilidad para aislarnos: Chile es de por sí una especie de isla a la que no se puede penetrar sino por cierto número de puertos. Por eso nos es dado realizar fácilmente una incomunicacion que para la jeneralidlad de las naciones seria imposible.

Someter a cuarentena los buques que proceden de puertos infestados no es una medilla de eficacia completa, ni que pueda dar jamás todas las garantías de seguridad que hai derecho a exijir en asuntos de tanta entidad.

En este sentido es mui justificado el descrédito en que va cayendo el sistema cuarentenario; la cuarentena, si no hai en realilad peligro es una ruina i si lo hai, de poco o nada sirve.

Creemos que solo en los casos de afecciones dudosas sobrevenidas a bordo de los buques que arriban a nuestros puertos i en jeneral en todas las naves cuyos puertos de procedencia ofrezcan un estarlo sanitario sospechoso, es en los que conviene imponer la cucrentena de observacion establecida por nuestro reglamento de sanidad marítima de fecha 18 de octubre de 1878.

En cuanto a las embarcaciones, viajeros, ganados, mercaderías, procedentes de lugares ciertamente infestados, no puede vacilarse en escojer medios: hai uno que se impone ciegamente, el de cortar en el acto tode comunicácion, de le manera mas rigorosa, con uquellos puntos.

Contra esta medida violenta como contra las cuarentenas se levantan dos clases de objeciones: $10^{\circ}$ la de los médicos que niegan la contajiosidad del cólera; $2{ }^{\circ}$ la de los que solo miran por los intereses del comercio. A los primeros basta ohservarles que sea o 
no sea contajioso el cólera, comuníquese o no del hombre al hombre, el hecho innegable es que jamás ha pasado de un lugar a otro sin que sea el hombre quien lo ha llevado, así como tambien que en varios casos ha bastado el aislamiento completo para mantener sano i salvo un pueblo vecino de otros que la epidemia arrasa. Recuérdese la salvacion de las islas de Sicilia, Chipre i Curazao i la de Grecia en todas las epidemias con escepcion de la que tuvo lugar durante la guerra de Crimea, en la cual le comunicó el cólera el ejército frances. Ispahan logró en 1821 evitar el cólera cerrando sus puertas a las caravanas, i Creta, en 1865, aislándose estrictamente. A los que quieren subordinarlo torlo a los intereses mercantiles, bastará observarles que los gobiernos no tienen derecho para ponerse a estimar en dinero la vida i ni siquiera la salud de los hombres. Un distinguido hijienista arjentino ha dicho: «La clausura de los puertos por motivos sanitarios es un alto ejemplo de moralidad, de virtud i humanidad.»-(Dr. Mallo.)

Se haria necesario que la autoridad, informándose exactamente de los progresos que hace en el estranjero la cpidemia, cuidara de hacer oportunamente declaracion de los puertos i paises con los cuales debiéramos cortar relaciones. Con esto se obtendria, entre otras, la ventaja, mui humanitaria por cierto, de evitar que salgan de los sitios infestados navegantes o viajeros espuestos a encontrar todas las puertas cerradas.

La determinacion de los puertos condenados podria hacerse por medio de ajentes chilenos que serian instalados en los puntas que puedan amenazarnos. Una comision pasajera de esta clase, encargada a médicos compatriotas, daria beneficios análogos a los obtenidos por la Europa de la «Comision Sanitaria Internacional»establecida en Constantinopla i las rejiones próximas, visitando constantemente los progresos de la peste en Mesopotamia.

La incomunicacion debe cumplir con todas las condiciones necesarias para evitar cualquier caso de infraccion. Debe estar basada en el conocimiento de la marcha de la enfermedad i no debe cesar sino con el fin de la epidemia; mas no por esto cesará la vijjilancia si este fin coincide con la entrada del invierno, porque al volver la primavera podria reaparecer el mal.

No puede negarse que en teoría hai otro sistema de aislamiento no tan rigoroso ni estremado i que sin embargo se ajusta a la nocion científica que ya poseemos sobre el modo de propagacion del cólera: es una especie de cuarentena en que se combina el aislamiento con la olwervacion. Para realizarlo, en nuestro caso por. 
ejemplo, deberíamos colocar en un punto del paso de Uspallata una guardia que detuviera a todos los viajeros i objetos que con. ducen i una comision de facultativos que examinase el estado sanitario de los viajeros e infeccioso de sus equipajes. Los individuos no sospechosos seguirian en el acto su viaje; los sospechosos permanecerian en observacion durante siete dias en el mismo sitio; los enfermos serian aislados $\mathrm{i}$ asistidos alli mismo. Por este sistema se conciliarian ciertamente los intereses sanitarios i los mercantiles; pero habria tan considerables dificultades para su perfecta aplicacion práctica que seria una temeridad confiar en él.

No mencionaríamos la práctica tan corriente i tan vulgarizada de las fumigaciones de los viajeros i de las balijas, si simplemente fuera ella inútil; la mencionaremos para condenarla ccn enerjía porque sobre ser inútil es peligrosa, desde que, inspirando una confianza injustificada, induce a recibir como libres de contajio objetos i personas infestadas. Supongamos un individuo que traiga en el cutis o en la ropa materias coléricas; la desinfeccion que tuviera poder suficiente para matar el jérmen de enfermedad mataria primero al individuo. Supongamos, lo que rarísima vez ocurre, una balija infestada del mismo modo; un desinfectante eficaz seria el que penetrase a traves de los cierros i por entre los pliegues del papel $i$ esto no puede realizarse sino con el vapor a alta presion, el cual es en la práctica casi inaplicable i podria malograr la correspondencia, o bien con el calentamiento a una alta temperatura, lo que exijiria aparatos de alguna delicadeza.

Por otra parte, la fumigacion i libre tránsito de la correspondencia hace ilusoria toda incomunicacion absoluta; la balija tiene que ser conducida por un balijero, i esto es peligroso aun sin contar con el abuso a que puede dar lugar.

cómo mpedir su desarroglo si zLega a peNetrar en CHILe KL CÓLERA

Las medidas que en tal circunstancia deberian adoptarse son de dos categorías bien distintus: medidas de hijiene pública, cuya planteacion corresponde a la autoridad administrativa i medidas de hijiene privala, cuya observancia es del resorte de cada individuo en particular.

$$
\text { Reglus de hijiene pública. }
$$

La primera que debe darse es la de mantener la incomunicacion absoluta por mar i tierra con los lugares estranjeros infestados. 
No porque ya hubiera penetrado a nuestro territorio la enfermedad habríamos de suspender la incomunicacion, supuesto que cada nucvo individuo enfermo que despues siguiera llegando constituiria un nuevo foco de propagacion.

Seria absolutamente necesario en el acto de presentarse un caso establecer para con el lugar en que éste aparezca la misma incomunicacion que para con los lugares estranjeros infestados. Esta incomunicacion deberá cumplir con todas las condiciones arriba indicadas i aplicarse igualmente a toda clase de personas i de objetos: viajeros, correos, navíos, vehículos, ferrocarriles, ganados, mercaderías, equipajes, etc. No se permitirá otra comunicacion que aquella estrictamente indispensable para aportar socorros, i esa ha de efectuarse con toda precaucion.

No es de ménos necesidad la observancia del precepto siguiente:

En el pueblo mismo en que aparezca el cólera se deberán aislar perfectamente los primeros casos; ya trasportando al enfermo a un local adecuado, ya dejándolo en su domicilio, pero alejando a todas las personas de la casa $\mathrm{i}$ del vecindario que no sean necesarias para su cuidado.

Con el objeto de hacer posible la pronta aplicacion del aislamiento i demas precauciones, debe hacerse obligatoria la declaracion ante la autoridad de los casos que oeurran con carácter sospechoso o evidente de cólera. La autoridad hará entónces comprobar por medio de médicos competentes la naturalcza de la enfermedad $\mathrm{i}$, si ha habido defuncion, las causas de la muerte por medio de la autopsia.

Lo dicho tiene por objeto llegar al aislemiento de los coléricos. Este objeto és el primordial; en seguida viene otro que casi no le cede en importancia: el suneumiento o hijienisacion de torlo aquello que pueda servir para trasportar, para alojar o para propagar el jérmen del cólera.

En una palabra, la autoridad debe una vez que haya atendido al aislamiento atender al saneamiento. E insistimos en este punto para desvanecer un error que va abriéndose mucho camino: el de que primero está la hijienizacion que el aislamiento. No hai tal: el cólera es el producto de un jérmen, de una semilla especial; a donde no es llovada esta semilla es materialmente imposible que haya cólera. El pueblo mas salubre sufrirá del cólera si penetran coléricos en él; i jamás tendrá cólera el pueblo mas inmundo i miserable si nadie le lleva el jérmen. La salubrificacion de una ciudad sirve, pues, para que no cunda entre sus habitantes la epide- 
mia; pero nada mas que para eso; solo el aislamiento para con los sitios infestados es capaz de impedir que nazca la plaga.

Siendo a menudo repentina la aparicion del cólera, las medidas precautorias deben ser tomadas con anticipacion. La esperiencia ha enseñado que la rapidez con que toma cuerpo depende en no poca parte del grado de salubridad en que sorprende a las ciudades i a las personas. De aquí deriva la utilidad de los preceptos que tienen por objeto robar al jérmen del cólera sus elementos de vida, convirtiendo nuestras casas, ciudades i campos en terreno estéril para su jerminacion i desarrollo, en una palabra, salubrificando, hijienizando a las personas i a cuanto con ellas se relaciona.

A continuacion van los principales preceptos que se han dictado o ensayado por los principales hijienistas i los Gobiernos como medidas prévias:

Instituir un servicio médico hijiénico bien organizado. Este ha de estar revestido de ciesta autoridad propia; ha de tener unidad en su organizacion; sus ramiticaciones han de establecerse en todas las ciudades i en los campos mas poblados; el número de sus funcionarios ha de ser suficiente para que ningun punto habitado quede sustraido a la vijilancia hijiénica.

Salubrificar todas las poblaciones.

Preparar los medios de aislamiento.

Proveerse de los medios de desinfeccion.

Preparar de antemano en las ciudades amenazadas ambulancias para socorros inmediatos situándolas en varios puntos de la ciudad. En el cólerå es de grandísima importancia que el tratamiento facultativo empiece lo mas pronto posible.

Alistar asimismo en los hospitales departamentos bien aislados para asistir en los casos dę urjencia i separar en el acto a los enfermos del hospital que contraigan el cólera.

Construir hospitales-barracas en los afueras i aguas abajo de las ciudades con el destino esclusivo de asistir coléricos. Estos hospitales tendrán departamentos privados para los que quieran curarse por su cuenta. El material con que se les construya deberá ser de calidad tal que el fuego pueda destruirlos totalmente una vez pasada la epidemia.

Preparar coches i carros especiales para la traslacion de los enfesmos i de las ropas, camas i otros objetos infestados.

Preparar casas para alojar a las familias de los enfermos, las 
cuales deberán siempre abandonar a lo ménos por tres dias la casa en que alguien se enferme.

Tomar en arriendo con este objeto las casas que al principiar la epidemia estén desocupadas en la ciudad.

Conservar en estado de perfecto aseo los lugares públicos, calles, plazas, mataderos, mercados, colejios, prisiones, hospitales, etc., etc.

Redoblar la vijilancia sobre la calidad de los alimentos que se venden, sobre el aseo de los lugares públicos i privados i sobre el buen estado de los sistemas de desagüe, ordenando el desalojo inmediato de las habitaciones que se hallen en malas condiciones hijiénicas.

Someter a visitas sanitarias periódicas los establecimientos industriąles insalubres, como jabonerías, curtidurías, caballerizas, etc., obligando a los dueños a practicar los trabajos necesarios para el saneamiento.

Suprimir en absoluto todas las materias corruptibles que pue. den constituir focos de fermentacion i putrefaccion; si son secas, como las basuras, destruirlas por el fuego; si húmedas, como el cieno i las materias fecales, conducirlas a distancia de los lugares habitados.

Suprimir i evitar todo lo que pueda causar un estancamiento de aguas, como derrames, charcos, pantanos. lagunas, rios de poca corriente, etc.

Hacer obligatoria para los médicos-cirujanos, dueños de casa, jefes de taller, administradores de hotel, rectores de colejios, etc.' la declaracion inmediata ante la autoridad local de los casos que ocurran bajo su dependencia o que lleguen a su conocimiento; para hacerla debe fijarse un plazo que no exceda de doce horas.

No podemos resistir a la tentacion de citar un hecho que prueba que la influencia bienhechora de la hijienizacion de una ciudad es casi omnipotente: este es la inmunidad de que Roma gozó en la epidenia de 1885. Nunca ha habido ciudad mas amenazada por el cólera que la de Roma en ese año; en tanto que en Nápoles la epidemia se habia cebado con tal violencia que en un solo dia, el 10 de setiembre, hubo 474 defunciones i 966 casos nuevos, Roma que recibia diariamente a los fujitivos de Nápoles, gozaba de un estado de salubridad perfecta. ¿A qué se debió este milagro? No a una inmunidad natural de Roma porque en 1837 esta fué una de las ciudades mas asoladas por el cólena; sí a las cuerdas precauciones adoptadas con varios meses de anticipacion por su enér- 
jico síndico o intendente el duque de Torlonia: aprovechándose de la abundante i excelente provision de agua potable, mayor que la de cualquiera otra ciudad del mundo (300 litros por dia i por habitante), el síndico pudo aplicar la heróica medida de tapiar todos los pozos de Roma reemplazándolos por 130 nuevos conductos de la «aqua marcia»; al mismo tiempo ejerció una de las mas estrictas vijilancias sobre el aseo de las casas i los patios i aplicó con una severidad draconiana en las puertas de la ciudad las reglas de prohibicion o destruccion de todo artículo de consumo considerado como capaz de dañar a la salud.

Las reglas siguientes son las que debe plantear la autoridad siempre que el cólera se haya declarado en una localidad con el carácter de epidemia reinante.

Enviar a todos los enfermos al lazareto especial, esceptuando a aquellos que para quedar en sus casas cumplan con estas dos condiciones, aislamiento completo a no ser con respecto a los cuidadores i colocacion en la puerta de calle de un cartel que anuncie la enfermedad contajiosa. El permiso de curarse a domicilio debe ser concedido en los ménos casos posibles pues que sin traer ningun provecho positivo para el paciente presenta inconvenientes para la ciudad entera i sobre todo para las familias que vengan a ocupar mas tarde la casa.

Estadística levantada en la epidemia de Inglaterra en los años 1848 i 1849 por el doctor Sutherland probó que el 87 por $100 \mathrm{de}$ los casos ocurrian en casas donde habia habido íntes un colérico.

Hacer cerrar durante seis semanas la pieza en que sobrevenga la enfermedad despues de quemar en ella a puerta cerrada cierta cantidad de azufre o de súlfuro de carbono en la proporcion de 30 gramos por cada un metro cúbico de capacidad. Esperiencias mui recientes de Pasteur, Kaupp i otros manifiestan que para este objeto el mas eficaz de los desinfectantes es el ácido sulfuroso i el medio mas ćmodo de obtenerlo la combustion del súlfuro de carbono.

La dósis de este gas debe ser la que esperimentalmente se ha demostrado necesitarse para destruir la virulencia o inoculabilidad de los virus. Sternberg de Washington hizo ver que quemando 16 gramos de azufre por metro cúbico la vacuna desecada espuesta en el recinto pierde toda actividad. Vallin, esponiendo a los vapores de 20 gramos de azufre por metro cúbico el virus del muermo i de 25 a 30 gramos el virus tuberculoso, les ha hecho perder su inoculabilidad.

Una dósis excesiva tiene sus inconvenientes cuando ha de obrar 
sobre vestidos $\mathrm{u}$ otros tejidos, pues destruye su coloracion i altera mas profundamente su textura.

Para que este empleo del ácido sulfuroso sea eficaz es menester que la atmósfera de la habitacion se halle húmeda i esto se consigue rociando préviamente con agua parades i suelo.

Disponer que en los casos en que las ropas i camas de los coléricos no puedan ser llevadas a las estufas públicas se les someta a algunos de los siguientes tratamientos: cuando sea posible, quemarlos, cuando nó sumejirlos durante media hora en agua hirriente o mejor en lejia hirviente (cuya temperatura pasa de cien grados). Esto se entiende sin perjuicio de la desinfeccion inmediata que deberá practicarse en todos los objetos manchados.

Trasladar los cadáveres de coléricos lo mas pronto posible a una casa mortuoria, establecimiento donde se vijilarán para descubrir los casos de muerte aparente tan comunes en esta enfermedad. Envolverlos inmediatamente despues de la muerte en sábanas empapadas de una disolucion desinfectante.

Disponer la cremacion de los cadáveres i cuando esto no sea practicable inhumarlos sobre un lecho de materia desinfectante. En este último caso, el suelo en que sean sepultados los coléricos se debe condenar a no ser cavado, ni removido, ni edificado janás.

No reducir el plazo legal de 24 horas que debe trascurrir ántes de la inhumacion.

Emplear en el riego de las calles agua limpia i siempre que se pueda cargada de cloruro de calcio o hipocloritos alcalinos, sus. tancias que por su cualidad higroscópica impiden la desecacion del suelo i dan lugar a un desarrollo constante de cloro que en la atmósfera neutralizará las emanaciones morbíficas i en el suelo podrá impedir el desarrollo de los jérmenes que contiene el polvo de las calles.

Puede recomendarse tambien labar las calles con una cantidad abundante de agua valiéndose de las bombas de incendio como se ha practicado en Inglaterra.

Instituir en los diversos barrios comités de vijilancia que tendrán a su cargo el velar sobre ei cumplimiento de los reglamentos sanitarios, denunciar las insfracciones, distribuir desinfectantes i $\mathrm{i}$ en jeneral encargarse de la cjecucion de las disposiciones que dicte la autoridad contra la epilenia. Estos comités pueden formarse con vecinos respetables, naturaimente interesados en la salubridad de su barrio, entre otros con los maestros i maestras de escuela cuyos servicios de tales habrán sido suspendidos. 


\section{$-23-$}

Nombrar mélicos inspectores en número suficiente para hacer visitas cuotidianas en todas las casas de la ciudad llevando consigo todas las medicinas necesarias contra las diarreas premonitorias para que las administren en el acto. Esta medida ha dado espléndidos resultados en Inglaterra donde la administracion estableció el año 1849 un servicio de mas de cien médicos visitadores que bajo la vijilancia del consejo de sanidad de Lóndres iban de casa en casa informándose de la existencia de esta diarrea i dando las medicinas convenientes para cortarla. Sobre 130,000 enfermos tratados de esta inanera no hubo sino 250 casos completos de cólera aunque 6,000 a lo ménos toca $\$$ y ya el período característico de la enfermad.

Asimilar con los militares muertos en campaña para los efectos de las pensiones que gozan sus familias, a los individuos que durante una epidemia de cólera mueran por causa de esta enfermedad prestando sus servicios en alguna de las condiciones siguientes: médicos cirujanos, practicantes, enfermeros, hoticarios, empleados de hospital o de cementerio, hermanas de caridad, capellanes.

Aplicar rigorosamente a todos los infractores de las disposiciones sanitarias las penas determinadas por el artículo 318 del Có digo Penal.

Distribuir al pueblo instrucciones sobre los medios de precaverse de la enfermedad i de combatir sus primeros síntomas hasta la llegada del médico.

Dispersar las aglomeraciones de individuos que puedan constituirse un medio de propagacion de la enfermedad; como escuelas, grandes talleres, etc.

Prohibir las grandes reuniones de personas, como las que se verifican en calles, teatros, iglevias.

Hacer acampar fuera de la ciudad a todas las tropas que forman su guarnicion.

Preparar i distribuir gratuitamente materias desinfectantes, que lleven sobre el envase una indicacion sobre el modo de usarlas.

Establecer en lugares centrales hornos o estufas para fumigar $\mathrm{i}$ desinfectar con vapor de agua o ácido sulfuroso los vestidos, camas, etc., manchados.

$$
\text { Reglas de lijiene privada }
$$

El cólera es una enfermedad que cuando se hace epidémica ataca a una proporción mayor de personas que cualquiera otra i que producc la muerte en una tercera parte de los easos, a veces en la 
mitad i hasta en las nueve decimas partes de los atacados. Se manifiesta por los siguientes síntomas, aislados unas veces, otras reunidos: malestar jeneral, vértigos, dolores en los miembros, sudores frios, ansiedad en la boca del estómago, ruido de tripas, vómitos i diarrea (síntoma principal i característico), de abundancia variable, de color blanquecino, de consistencia mui líquida i que apénas mancha la ropa. En los casos graves se agregan supresion de orinas, enfriamiento jeneral con sensacion de calor interno, descomposicion del semblante, apagamiento de la voz, calambres dolorosos, enflaquecimiento rápido, coloracion azul de la piel i muerte.

En los casos mortales la duracion de la enfermedad es por término medio de 48 horas. En la mayoría de los casos, la enfermedad empieza por la diarrea que se ha llamado premonitoria, que es relativamente un síntoma benigno, susceptible de ser cortado fácilmente, con lo cual se evita la manifestacion del cólera grave o confirmado.

En Chile como en todas partes hai una enfermedad que es punto por punto igual al cólera en todo, salvo en su naturaleza, es decir, que se diferencia solo en estos dos caractéres: no nacer en la India; no propagarse del hombre enfermo al hombre sano. Esta enfermedad es la colerina, cólera nostras, indíjena o esporádico, lepidia de calambre, que se orijina por causa de las vicisitudes atmosféricas en las estaciones de transicion, principalmente la entrada del verano i a la cual favorecen los desarreglos de réjimen (limonadas, frutas ácidas, chicha, helados, ete.)

Como algunas veces las condiciones productoras de esta enfermedad concurren en varias personas simultáneamente, suele tomar el aspecto de epidemia i como ademas puede terminarse con la muerte, no es raro que dé motivo al vulgo para creer cuando se tiene al frente uno de estos casos que se trata del cólera asiático. Error contra el cual conviene estar prevenido.

Es bueno tener presente que el contacto por sí solo de un colérico no determina la enfermedad; que la respiracion del aire que exhala al enfermo tampoco contajia porque el principio morboso no es volátil; que todo el peligro está en la introduccion dentro de nuestro cuerpo por cualquier vía, pero sobre todo por la vía dijestiva, de las materias vomitadas o defecadas por un colérico, sea que se hallen todavía líquidas, sea solidificadas o secas por la natural evaporacion de su humedad.

Apesar de lo dicho, hai una circunstancia escepcional que hace posible la existencia momentánea de jérmenes de cólera en el aire: 


\section{$-25-$}

cuando mecánicamente son divididas en partículas pequeñísimas. Por ejemplo, cuando se sacude una alfombra sobre la cual existen materias vomitadas o defecadas de un colérico, éstas se dividen en partículas pulverulentas que flotan por algun tiempo en el aire i que pueden absorverse adheridas a los liquidos de la nariz, el pulmon o la boca.

Está averiguado que quien guarde con esmero los preceptos de la hijiene ordinaria, quien lleve una vida arreglada i sobretodo quien ataque debidamente los primeros síntomas (la diarrea que es el preludio del cólera) puede contar con salvarse.

El aseo de las personas i de las habitaciones, la respiracion de una atmósfera seca i pura, el alejamiento de los sitios húmedos, inundados i pantanosos, la supresion de todas las causas de putrefaccion, son reglas esenciales.

Miéntras que las clases acomodadas que ocupan habitaciones hijiénicas quedan jeneralmente indemnes durante las epidemias, el proletariado en sus viviendas reducidas, húmedas, oscuras i sucias paga un enorme contiñjente a la mortalidad.

Se ha reconocido que en una misma ciudad los barrios mas bajos i declives son invadidos de preferencia por la enfermedad, hecho que se esplica por razon de que todas las inmundicias de los barrios altos fluyen hácia las partes bajas de la ciudad i en ellas se acumulan $\mathrm{i}$ ofrecen condiciones favorables para la vejetacion de los microbios.

Las causas de putrefaccion que no puedan alejarse inmediatamente deberán ser neutralizadas con sustancias desinfectantes: agregando en las materias fecales i aguas sucias por ejemplo, la solucion doble de nitrito de soda i alumbre o la solucion al 5 por ciento de sulfato de cobre o de fierro, cloruro o sulfato de zinc, ácido fénico, cloruro o cal o soluciones al 1 por 1,000 de sublimado corrosivo, o permanganato de potasa. Para desinfectar las atmósferas sospechosas convendrá una lechada de hipoclorito de cal en proporcion de 1 por ciento, con la cual se harán aspersiones en el aire, se regará el suelo o se llenarán depósitos de boca ancha. Para el mismo objeto puede servir el vinagre o la esencia de trementina o la de eucalipto hirviéndolos, i el azufre o el súlfuro de carbono quemándolos.

Las personas sanas deben preferir a los lugares comunes el uso de las bacinillas en cuyo fondo debe haber corstantemente cierta cantidad de solucion desinfectante. Es bueno que cada persona 
tenga uno de estos muebles destinado esclusivamente para su propio uso.

El aseo de las personas tiene una importancia capital en cuanto se refiere al aseo de las manos. Nada es mas fácil que ensuciarse las manos con escrementos de coléricos cuando se vive en un pais donde existe la epidemia; esto puede pasar de infinitos modos, ya estrechando la mano de un amigo que viene de asistir a un enfermo, ya recibiendo una moneda o un billete que poco ántes ha estado en poder de un colérico, o de una lavandera, o de un sepulturero, ya sacándose los botines manchados casualmente en la calle con escrementos de un enfermo, ya fumando un cigarro manoseado, etc. De las manos pasa entónces al estómago con suma facilidad el jérmen venenoso: o bien al introducirse los dedos en la boca, o bien al comer un alimento que se ha tocado con las manos manchadas de esta suerte. Por esta vía penetra casi siempre al cuerpo la causa de la enfermedad i en consecuencia hai que tomar sérias precauciones para que semejante cosa no suceda: $10^{\circ}$ lavándose las manos mas a menudo que de ordinario con agua de fuente notoriamente pura o con agua previamente hervida; $2 .^{\circ}$ no poniéndose los dedos en la boca; i $3 .^{\circ}$ desinfectándose las manos cada vez. que se vaya a la mesa, si por algun motivo se ha tenido que hacer en la proximidad de escrementos de coléricos; esta desinfeccion se hará sumerjiendo por medio minuto las manos en una solucion débil de sublimado corrosivo.

En jeneral, para el aseo personal debe emplearse tambien agua recien hervida.

El lavado de la ropa durante una epidemia ha de hacerse en la propia casa i tambien con agua cocida.

Son perjudiciales todas las causas de debilitamiento, como fatigas exajeradas, trasnocharlas, excesos ile trabajo o de placer, baños mui prolongados.

Jeneralmente aparece el cólera de noche i en compañía de un resfriado; deben por tanto evitarse todas las causas de estos últimos: falta de abrigo, cambios de ropa imprudentes «vientos colados», impresion del frio nocturno, hebidas frias en gran cantidad, uso de helados, etc.

Llevar una faja abrigadora en el abdowen es por una razon análoga mui útil.

Los vasos en que se toman alimentos o bebidas frias deberán ser siempre lavados ántes con agua hirviente, o mejor colocados en una estufa u horno de temperatura superior a $100^{\circ} \mathrm{o}$ bien $80^{-}$ 
Ulamados, es decir, sometidos un instante al contacto de una llama de alcohol:

Siendo probablemente las bebidas el medio mas frecuente de introduccion del veneno, no deben beberse las aguas naturales sin someterlas previamente a una ebullicion prolongada, i si no se bebe esta agua ántes de las 24 horas de hervida se deberá repetir la ebullicion. Razon ha tenido un hijienista para sentar como axioma salvador este precepto: «el gran anticolérico es el caldero de agua, hirviendo sobre el fogon».

Es preferible no beber pura esta agua cocida sino en infusion con pan quemado, té, lúpulo u otras yerbas amargas.

Las aguas minerales naturales pueden beberse sin peligro, con tal que sean jenuinas.

Las aguas traidas por buenas cañerías de lugares distantes perfectamente inmunes podrán tambien beberse al natural con confianza, despues de someterlas a la filtracion ordinaria, o a la filtracion en el filtro Chamberland construido bajo la direccion de Pastenr i que priva al agua de todo organismo por pequeño que sea. Mas no por esto ha de creerse que un agua bien filtrada, un agua exenta de microbios, no es susceptible de comunicar el cólera, pues como ya dijimos no parece ser la presencia del microbio mismo la que causa la enfermedad, sino la presencia de una sustancia producida por el microbio i esta sustancia, diluida en el agua, bien podria pasar a través de los poros del filtro mas fino.

En materia de aguas de bebida las mas peligrosas son aquellas a las euales se han mezclado por las grietas i roturas de los conductos o por la infiltracion natural del suelo materias escrementicias; las mas susceptibles de ser así inficionadas son naturalmente las aguas de noria.

El réjimen alimenticio no debe ser alterado durante las epidemias por las personas que acostumbraban comer con juicio. Se procurará hacer comidas cortas. Esto quiere decir que entre los individuos de nuestras clases acomodadas mas serán los que tengan que restrinjir la racion diaria que aquelios que se. verán en el caso de aumentarla.

Se tratará a toda costa de evitar las indijestiones: en todas las epidemias de cólera se ha observado que la intemperaneia abre las puertas a la enfermedad. Las bebidas alcohólicas deben evitarse a no ser por los individuos que acostumbraban beber vino en las comidas.

Conviene abstenerse de los alimentos vejetales que se comen 
crudos, como las frutas i verduras. Conviene cocerlas para destruir los jérmenes que pudieran haber arrastrado del suelo o de la atmósfera adhiriéndoseles por la superficie. En jeneral, todo alimento sospechoso debe ser o destruido o cocido de nuevo.

Uno de los preceptos mas importantes en cuanto a la hijiene de la alimentacion es el de conservar sano i fuerte el estómago. Muchos motivos hai para creer que cuando los jugos dijestivos ácidos que forma este órgano, poseen todas las condiciones del estado normal o fisiolójico matan i dijieren los jérmenes del cólera al ponerse en su contacto. De manera que al llegar al intestino donde hallan líquidos alcalinos adecuados para su propagacion, estos microbios están ya completamente privados de vitalidad, inofensivos, inertes.

Qué importancia no tendrá entónces durante una epidemia colérica el mantener en buen estado las funciones del estómago i el fortificarlas cuando han decaido: ¿Cómo conseguirlo? Con la ayuda de pocas modificaciones en la dietética habitual, con la abs. tencion de toda grave infraccion hijiénica i en caso necesario con alguna sencilla medicina.

Otra precaucion no mui insignificante que ha de tomarse con la alimentacion en tiempo de cólera es la de cuidarse de las moscas Está en efecto averiguado que estos insectos contribuyen no poco a la difusion del cólera, lo mismo que a la de varias otras enfermedades infecciosas. Inmundos i glotones, pasan estos seres sin cesar de nuestros manjares mas esquisitos a la porquería mas asquerosa, i vice-versa, depositando en la una partículas de la otra; sobre el abdómen de moscas que acababan de posarse en una de. yeccion colérica se ha observado el bacilo vírgula. Los alimentos que se comen crudos i los que se dejan afiambrar son los mas espuestos a adquirir por este estraño procedimiento facultades venenosas; cúidese por consiguiente de no comer cosa cruda ni fiambre sino cuando hai certeza de que no ha sido tocada por las moscas.

Procúrese por lo mismo no tomar frutas crudas sin privarlas ántes de su superficie natural.

Las nueces. por ejemplo, las almendras i las avellanas, cuya cáscara se saca en la misma mesa, i que se comen en el acto; las peras las manzanas, los higos i los duraznos de cáscara integra, que se mondan tambien en la mesa i se comen en seguida; las sandías, los melones que se sirven apenas cortados; la lechuga, el apio i los rábanos que se comen despues de haberlos lavado bien con agua na- 
turalmente pura $\mathrm{i}$ hervida, etc., ninguno de estos alimentos podrá contener microbros colerijenos, i por lo tanto pueden hacer uso de ellos los que los dijieren bien.

Pero seria imprudente comer, por ejemplo, una tajada de sandía que ha estado espuesta al aire libre en el mercado o en la casa, o una pera podrida i con cáscara dañada, o una ensalada de lechuga no bien lavada, o lavada con una agua sospechosa, etc. Así podrá confiarse en que no están contaminadas por las moscas, portadoras de microbios coleríjenos, los pedazos de carne fria, o de queso, o de salchichon, etc., i las mismas frutas cortadas i mondadas que no han sido comidas inmediatanente, cuando se ha tenido la precaucion de tenerlo todo continumente conservado dentro de fambceras eficazmente protectoras.

Eś un lamentable error el de los que piensan resguardarse del cólera con las bebidas alcohólicas. Puede que en realidad les sirvar ellas parn matar el miedo; pero que eviten que el jérmen coleríjemo introducido en su cuerpo los perjudique, eso nó; por el contrario quizás habria motivo para pensar que el alcohol modifica la economía animal, de una manera que la hace mas susceptible a ser afectada por el ajente coleríjeno; en efecto, los esperimentadores no habian logrado hacer prender el cólera en los animales por mas que les inyectaban en la sangre i les hacian comer deyecciones de coléricos i familias enteras de microbios coléricos cultivados artificialmente; pues bien, Koch logró hacer prender el colera en los cuyes sin mas que inyectarles préviamente en el abdomen una cantidad de alcohol.

Puede que algunos borrachos pasen una epidemia sin enfermarse pero esto nada significa, pues que sin la bebida talvez no habrian tampoco contraido el cólera.

Evidentemente la adopcion de un número mayor o menor de estas medidas i su mas o ménos estricta aplicacion habrán de proporcionarse a la intensidad de la epidemia i tambien a las mayores o menores ocasiones de contajio a que el individuo se espone. No son los mismos, por ejemplo, los cuidados que ha de tener un hombre de oficina que los que ha de tener un enfermero de coléricos. Estos últimos han de observarlas todas con estrictez: para ellos aun es para quienes se ha dado el consejo de no emplear como agua para el aseo personal sino la que haya sido hervida $i$ adicionada de sublimado corrosivo o ácido fénico; el- consejo de no tomar alimeńto alguno sino en platos previamente sollamados, etc.

Otro precepto que puede ser de utilidad es el de abastecer la 
despensa, cuando amenaza el cólera, de todas aquellas provisiones de boca que son susceptibles de una conservacion prolongada: verbigracia, azúcar, fideos, arroz, charqui, harina, queso. Miéntras ménos objetos de fuera se introduzcan a la casa durante el reinado de una epidemia, ménos probabilidades habrá de qne penetre el enemigo.

\section{REGLAS DE HIJIENE PRIVADA EN CASO DE ENFERMEDAD}

Cuando se está bajo el dominio de una epidemia de cólera, cada vez que sobrevenga cualquier desarreglo de la dijestion como vómitos o diarrea, es indispensable hacerse ver por un médico, guardando cama miéntras tanto, procurando sudar con mucho abrigo $\mathrm{i}$ con una infusion caliente de té, sahuco o tilo i observando dieta absoluta, en otros términos, privándose de todo alimento.

Si el cólera verdadero se declara deberán tomarse con el enfermo las precauciones siguientes que van tanto en su interés como en el de las personas que lo rodean.

Las guardias o turnos de los enfermeros o cuidadores no deberán durar mas de doce horas.

Se harán desaparecer lo mas pronto posible de la pieza del enfermo las materias del vómito i las deposiciones. Antes de vaciarlas en las acequias, pozos o cauces de la casa serán perfectamente desinfectadas.

Las ropas manchadas con estas materias serán sumerjidas ántes de sacarlas de la pieza en una solucion desinfectante. Los vestidos de lana no susceptibles de lavado se enviarán a la estufa de desinfeccion o se destruirán por el fuego; lo mismo debe hacerse con las camas.

Convendrá colocar entre el colchon i las sábanas grandes hojas de periódicos o de papel alquitranado o de papel pergamino para evitar las manchas del colchon, papeles que despues serán quemados, regla aplicable sobre todo a los hospitales.

Las aguas sucias i los desperdicios de cocina serán mantenidos despues de la desinfeccion en tiestos tapados para ser entregados todas las mañanas a los carretones públicos.

Cuando se tiene un colérico, sea en una casa particular, sea a bordo de una nave, sea en un hospital, entónces es cuando toma toda su importancia la desinfeccion. Esta debe aplicarse a cuanta cosa haya estado en contacto con las materias evacuadas o vomitadas por el colérico, i a estas materias mismas. 
Como medios de desinfeccion que pueden ponerse en la mano de todo el mundo se recomiendan:

$1 .^{\circ}$ La destruccion por el fuego,

2. El agua i la lejía hirvientes,

$3 .^{\circ}$ El vapor de agua a $100^{\circ}$ de temperatura,

4. El ácido fénico,

$5 .^{\circ}$ El clormo de cal,

$60^{\circ} \mathrm{El}$ sulfato de fierro i el sulfato de cobre.

7. ${ }^{\circ} \mathrm{El}$ nitrito de soda;

Hai algunos otros desinfectantes (que tambien mencionamos en otra parte) pero tienen indicaciones especiales $\mathrm{i}$ algunos ademas cierto peligro por ser venenosos.

En jeneral, bastará con tener preparadas las siguientes soluciones en agua: debiles, con 2 por ciento de ácido fénico o 1 por ciento de cloruro de cal; fuertes, con 5 por ciento de cualquiera de estas mismas sustancias.

La aplicacion de estos medios se hará como sigue:

Para la desinfeccion de las personas: lavados i baños con una de las soluciones débiles;

Para la desinfeccion de la ropa blanca, los vestidos, la ropa de la cama, las frazadas i demas artículos análogos: a) la destruccion; b) el vapor que se hace pasar a traves de estos objetos durante una hora; c) la ebullicion durante 30 minutos; d) la sumersion por $\mathbf{2 4}$ horas en una de las soluciones débiles; e) la aireacion (al sereno) durante tres o cuatro semanas, pero solo en los casos en que ninguno de los otros inedios sea aplicable. Los objetos de cuero, como maletas, botas, etc., serán o destruidos o lavados repetidas veces con una de las soluciones débiles;

Los vómitos $\mathrm{i}$ las deposiciones serán mezclados con una de las soluciones fuertes. Las piezas de ropa, sábanas, frazadas, vestidos recien manchados, que no pueden ser sometidos al vapor inmediatamente, serán pronto sumerjidos en las mismas soluciones fuertes: permanecerán en ellas 4 horas;

En los hospitales de coléricos todas las paredes de las salas se lavarán con una de las soluciones débiles i despues se airearán, en seguida se lavarán i por último se pintarán de nuevo, separando en lo posible de las otras la sala sometida a la desinfección;

Las letrinas se desinfectarán a lo ménos dos veces al dia, vaciando en ellas soluciones fuertes en cantidad igual por lo ménos a la de las deyecciones recojidas desde la última desinfeccion;

Los vestidos del personal de los hospitales permanecerán siem- 
pre en el establecimiento i serán regularmente desinfectados. Para sus lavados el personal se servirá de algunas de las soluciones débiles ya indicadas o de la solucion de sublimado al 1 por 5000 .

De ordinario el pánico induce a los habitantes de las ciudades en que prende el cólera a buscar su salvacion en la fuga. Lamentable determinacion que los espone a arrastrar consigo el mal i a ser víctimas suyas en los campos o las pequeñas aldeas donde se carece de toda clase de recursos. El temor aumentado por la fuga misma, las fatigas del viaje, el cambio de réjimen, todo contribuye a exajerar la predisposicion a la enfermedad.

Muchas personas acostumbran proveerse de medicamentos aconsejados por médicos de mas o ménos gran reputacion para usarlos cuando comienzan a sentirse atacados. Reprobamos en absoluto esta práctica: no hai remedio alguno que sirva para todos los casos de cólera, ni para todos los estados de la enfermedad, ni para todas las diferentes condiciones personales del enfermo (sexo, edad, constitucion, temperamento, costumbres, etc.) Las recetas de láudano aconsejadas por los diarios políticos i por cartillas hijiénicas atolondradas tienen que producir forzosamente muchas desgracias. Cuando mas, lo que podria recomendarse al público en esta materia seria el guardar en su casa algunos de los principales medicamentos que pueden llegar a necesitarse como el láudano, el tanino, el éter, la creta, el alcohol; pero solo para emplearlos por indicacion del facultativo; i sin que tenga este abastecimiento previo otro objeto que el de ahorrar el tiempo que se pierde en enviar a la botica.

Concluiremos con una reflexion de carácter jeneral.

Todo buen ciudadano ha de considerar como un deber sagrado el de prestar a la administracion todo el ausilio de que sea capaz, en consejo, trabajo i dinero, para luchar contra el flajelo.

Todo buen ciudadano ha de procurar que el espíritu del pueblo se mantenga animado durante la calamidad, pues el abatimiento i la pérdida de la fuerza moral postra las fuerzas físicas i priva al cuerpo de la resistencia contra la enfermedad.

Téngase entendido finalmente que los remedios secretos que siempre se preconizan a porfía en los tiempos de epidemia son inútiles, cuando no perjudiciales. Hasta ahora no se conoce específico alguno que sea preventivo del cólera, i verdaderamente si alguno llegara a descubrirse hai que convenir en que inmediatamente seria puesto en conocimiento del mundo entero, pues por grande que se suponga el egoismo humano es imposible concebir la existencia 
de un individuo capaz de reservarse para lucro propio un secreto que vendria a evitar tantas desgracias.

El resultado final de toda la esposicion que precede se resume en las siguientes proposiciones, que son todas ellas la espresion de verdad indiscutible:

Si el cólera se halla en los pueblos vecinos ipuede evitarse que entre a Chile.-Sí.

¿Cómo?-Aislándonos.

Si el cólera ha llegado a penetrar en Chile ies posible impedir que se propague?-Sí.

¿Cómo?-Dando aviso sin demora de los primeros casos que ocurran para que la autoridad aisle al enfermo i destruya sus productos contajiosos.

$\mathrm{Si}$ el cólera ha llegado a convertirse en epidemia ipuede uno evitar su ataque?-Sí.

¿Cómo?-Absteniéndose de tragar, tocar i respirar las materias procedentes del cuerpo de los coléricos.

Hé aquí conclusiones del carácter mas tranquilizador que pudiéramos desear. Deben ser creidas ciegamente porque están fundadas en la ciencia. Mas para que la enseñanza que de ellas se deriva sea eficaz deben ser aplicadas con estas dos condiciones:

Serenidad i prevision. 


\section{LOS VERSOS DEL CÓLERA ${ }^{19}$}

Pedro Villegas fue un poeta popular, autor de un conjunto de pliegos pertenecientes a la denominada Lira Popular. Los impresos eran vendidos por "canillitas" o por los mismos poetas en distintos puntos de la ciudad. sabemos que los pliegos de Pedro Villegas "se venden al pie de la estatua de O'Higgins". Entre sus versos destacan los que abordan temáticas sociales como la injusticia, la pobreza y la desigualdad.

Una de las grandes epidemias del siglo XIX en Chile fue la del cólera; a fines de 1886 se detectaron los primeros casos cerca de San Felipe y ya a inicios de 1888 se había propagado por todo el país. Una de las estrategias impulsadas por el gobierno para hacer frente a esta crisis fue la creación, en 1887, de un Comité Ejecutivo en Santiago y, a fines de ese mismo año, a través de un Decreto Supremo, de la Comisión Directiva del Servicio Sanitario del Cólera. Podemos acercarnos a la historia de las enfermedades y epidemias a través de acciones como estas, que quedan registradas en los documentos oficiales, sin embargo, son pocas las huellas que nos permiten acercarnos a las perspectivas y experiencias de la ciudadanía.

Es por esto que el documento que aquí presentamos, perteneciente a la Colección Lira Popular del Archivo Central Andrés Bello, posee gran valor, pues va más allá de la perspectiva médica y de la autoridad, lo que nos acerca a parte de las experiencias que los/as ciudadanos/as comunes vivieron ante esta enfermedad. El "pueta” Pedro Villegas plasmó en este pliego titulado "Los versos del cólera" las sensaciones de miedo a la muerte y la angustia e incertidumbre que provocó la llegada de la enfermedad a Chile. También se refiere a las formas de contagio, los lugares en el mundo donde la epidemia ya se había expandido y expresa preocupación por las consecuencias económicas que la situación podría tener en los sectores más pobres.

19. Villegas, Pedro. Los versos del cólera, ca. 1866-1930. Colección Lira Popular, Archivo Central Andrés Bello. Disponible en: https://bibliotecadigital.uchile.cl/discovery/delivery/56UDC_ INST:56UDC_INST/12175539760003936 


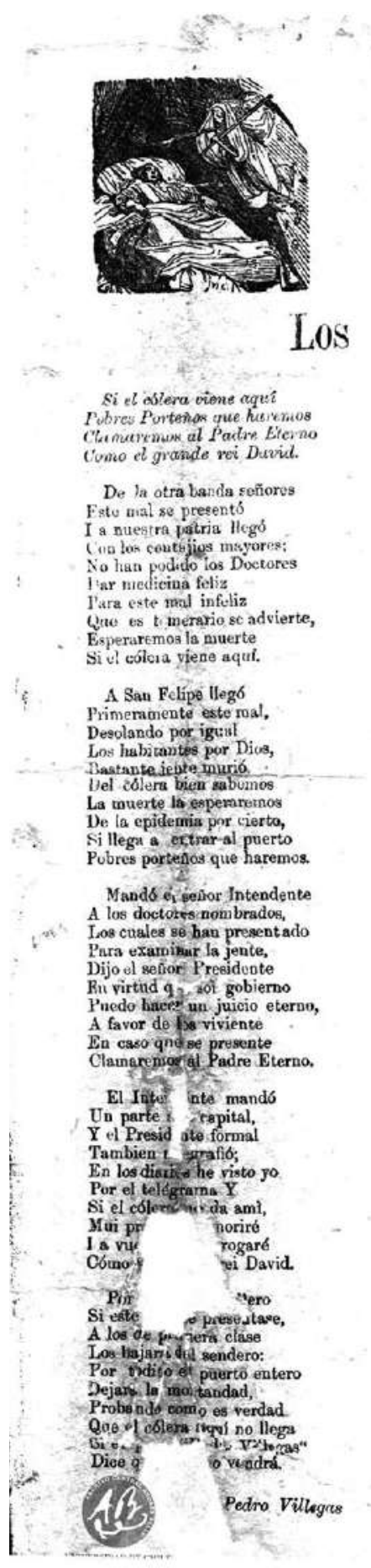

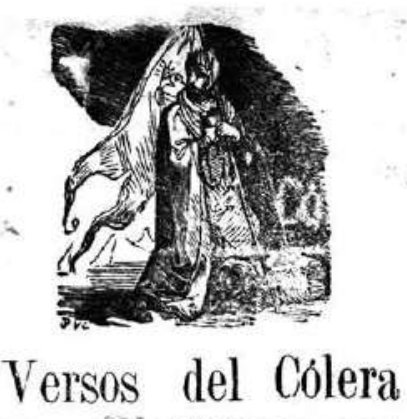

El colenten la Arjentina Fitce doble operierion,

$I$ si a meentro thite viene Arreinarde la acion.

Pobres fruteros que haremos Si signie mal el negucio,

la carabina de Anibro-io. Con el ticnpo racarumos. Fn trabajar no pentemos Poryue fesá moyor ruina, En Maipo, dicen las chinas ('ue crte mal quiere entrar;

Jorcued to han oido mentar

El cólera en la Arjentina.

Bit este puerto sereno Nu se conversa otra cosa,

Que el cólera está en Mlendoza, Kncima de los chilenos. Los porti'los estan llenes

De vuestra gus, dia en razon

Conversa la poblacion,

Que e-e mal, es como un aire Y il cólen en Buenos Aires Hace doble operacion.

Fn Córdoha jente muere

Del collera por mi Dios; Un aduanista murió Yor comer frutas infiere, Itueren homlires i mnjeres be ere mal que al corazon, Que triste lumentacion Para lns enyanos gerá $\mathrm{Y}$ aqni tamliea llegar ŝ Arruiando la vacion.

Anteriormente vendia Pam medio mantenerme, Y hoi dia no hallo qne bacerme Para poder pasar el dia Ln jente me compraria Prro si plata no tiene ¿Con qué diablo se mantiene Para componer el rostro QQue haremos todos nosotros Si el cólers a Chile viene?

Por ńltimo, lns frnteros Si el negocio sigue malo, Tenilrán que morder el palo, Lo mismo que peon aûero Trabajando el dia entero Para gannrse la vida: Si el qne oficio no tenfa, Por el tiem yo tristemente Pura ganar enatro veintes Trabajará todo el dia.

Pedro Villegas.

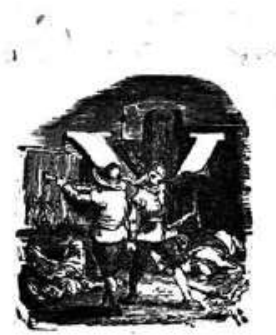

En la cuesta de Berboria En la citudal de Sadaria,

Heste el objeto Uejara Si me perara a Caforice.

La Grecia i ol Portugal Ciuco millones presenta, Y el poeta, cuarenta cuente Del Juyon en caso tal, Treoe millrnex cahal Hai ro la Colomhin, seria Bn el gran mar de Tiberia, Decian los stperiores Han de haber intechos cantores Eu la cuesta de Berberia.

Son doce las copilnleg Las que presenta la Expafia, La jente que la acompaña Son die ziocho mai cabales. La jer.grafin me vale Bu la ciudad de Samaria, Oyendo palabres diarias De enotores arbitrarios Habrán varios operarios En la ciudad de Sadaria.

Enciezisiete enmarcas Is Earopa está dividida, En graudes enpitanias Y el reino de Dinamarca Casi todo el mitudo abarea La mer, es cosa mui clara Yo todo el mar navegara; $Y$ a si es por esta razon, Mle enbarcara para el Japon Hasta el objeto llegara.

Haj cuatrocientos millones De habitantes en la gran Cbins, $\mathrm{Ni}$ la Europa que tau fina Le igusls en sus estenciones, Tieve tantas poblaciones: Pero se vé una miseria En la cindad cantiveria. Por eno que yo me fundo Fnese a rrecorrer el mundo Y me pasara a Caferia.

Todita la España entera

Titone dieziocho millones, Doans grandes poblaciones La Galicia es la primers Guipnscoa segunden

Por el tanto les avisos,

El andar sea preciso

Por el camiun de los Ander,

Donde habrá pierto mas grande Que el puerto de Valparaiso. 


\section{ELEMENTOS DE HIJIENE POPULAR ${ }^{20}$}

Ernestina Pérez (1865-1951) se graduó de Bachiller en Humanidades en 1883 y de Bachiller en Medicina y Farmacia en 1885. Recibió su título de médico cirujano de la Universidad de Chile el 10 de enero de 1887, siete días después que la doctora Eloísa Díaz.

En su tesis manuscrita, conservada por el Museo Nacional de Medicina dependiente de la Facultad de Medicina de la Universidad de Chile, propone que la higiene pública permite prevenir enfermedades y mejorar la calidad de vida por medio de hábitos (alimento, ejercicio, limpieza del cuerpo, crianza de niños, descanso y buen dormir, condiciones de la vivienda, vestido). El núcleo de su propuesta está en el régimen alimenticio, pues la doctora Pérez explica que la alimentación, en particular la carestía de la carne, tiene directa relación con la mortalidad y los nacimientos. Pérez nos proporciona valiosa y rica información sobre la dieta de inquilinos y artesanos, como también sobre la infancia, a la que dedica un capítulo completo.

Sus estudios de ginecología, al igual que los de Eloísa Díaz, siguen siendo fundamentales y pioneros por su mirada integral del ciclo de vida de las mujeres y el impacto del embarazo. Sin duda, en su tesis están los cimientos de sus caminos posteriores, en los que se dedicó a las mujeres, las amas de leche, las embarazadas y las trabajadoras afectadas por la tisis. En este texto, la doctora Pérez dice claramente que nadie se preocupa del momento posterior al parto, el "desembarazo", lo que causa gran parte de las muertes tanto de las madres como de los recién nacidos. Estos aspectos siguen siendo un pendiente en nuestra política pública actual, solo véase el debate por el postnatal en los últimos diez años y el llamado postnatal de emergencia en el contexto del Covid-19.

El mismo año en que presenta su tesis, 1887, ayudó a combatir la epidemia de cólera que se produjo en Valparaíso, por lo que fue nombrada "ciudadana ilustre" de esa ciudad. Ese año también ganó una beca financiada por el Estado para perfeccionarse en el extranjero. Ya en Berlín debió enfrentarse con un decreto imperial que prohibía a las mujeres realizar estudios científicos, pero finalmente pudo continuar y fue la primera mujer americana en estudiar en la Universidad Federico Guillermo, actual Universidad de Berlín. Así nos lo relata la historiadora Luisa Zanelli López en Mujeres chilenas de letras.

20. Pérez Barahona, Ernestina. [Manuscrito] Tesis (médico cirujano), Universidad de Chile, 1887. Museo Nacional de Medicina Enrique Laval, Universidad de Chile, Disponible en: https://bibliotecadigital.uchile.cl/discovery/delivery/56UDC_INST:56UDC_INST/ 12170203640003936 
REVISTA ANALES

Séptima Serie. No 16/2019

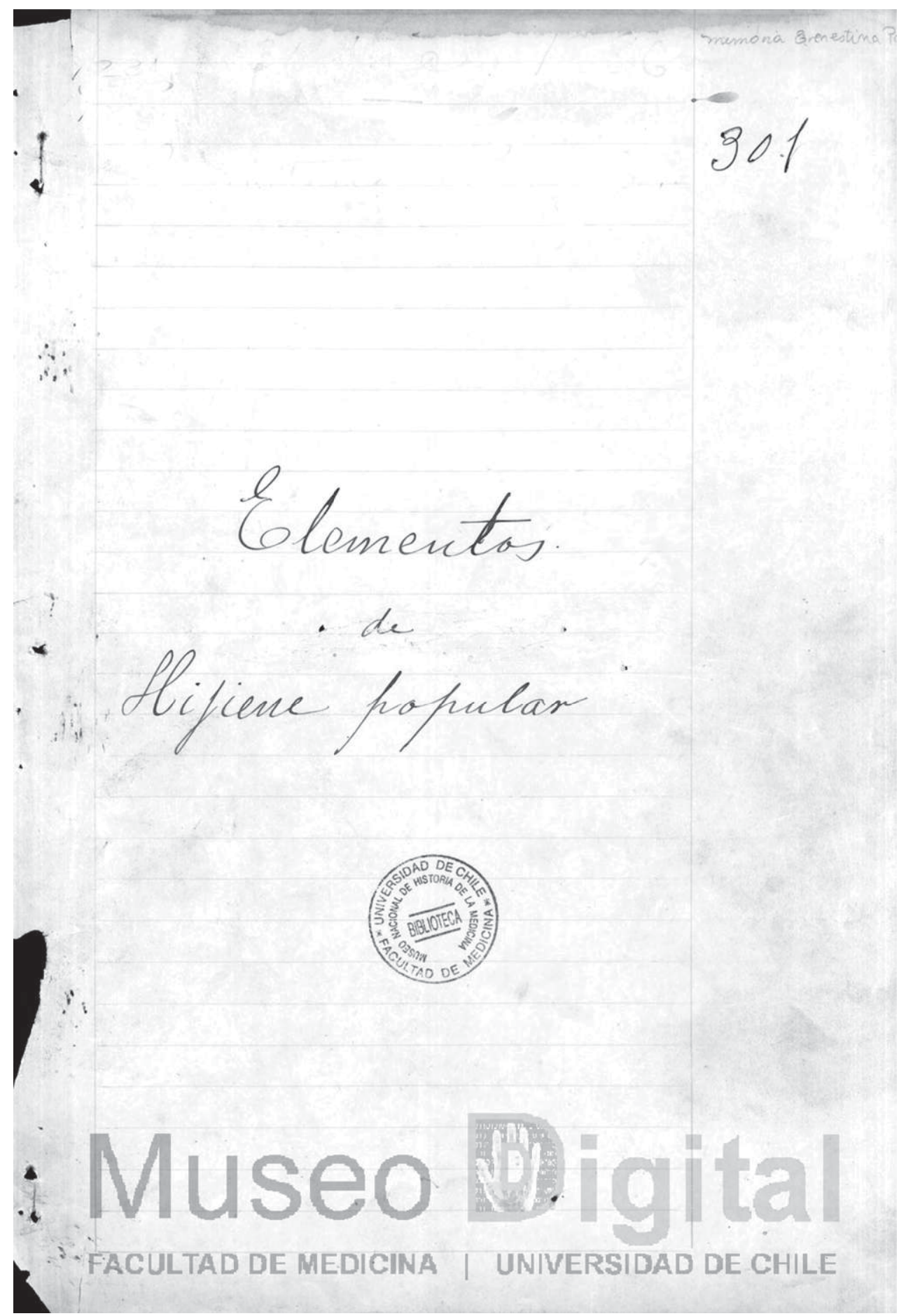

513 


$$
\begin{aligned}
& \text { Primesa parte. } \\
& \text { Papitulo primero }
\end{aligned}
$$

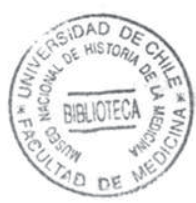

Definieion de higiene = de llama higiene ala eiencia que for medio de re glaso preceptos, noveneña la manera coneo debenoscanservas ba dabul if polangas. la vida.

Divisians de la higiene $=$ Puands $\mathrm{Le}$ elliea al individus en fastientas, el llanca frivada o doncetiea. heso. enandoduo endeñangas de refieren a las hanbre. que vivero en tocicesat, cano lao habtanted de ma cindad, colefir, enartel

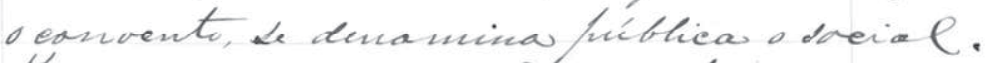
Infortaneia, utilidad de la hifienes. En un fais eano Chile, en que las enas vulfares novianes de enta importaute eicncias dou desconesilas, tanto forel funclo, coms for la pente unas onéros acomotada, la neeceidad de un conocila Le hace mas im heriasao, evando obscroamos

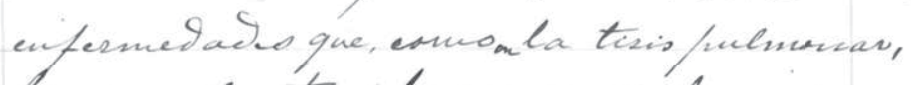
la viruela ete, la equsa de la enarme mostalidad de los hártudsos, afeeciaces

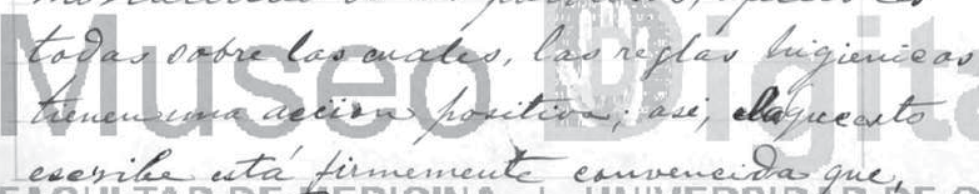
FACULTAD DEA FEICINA I UNIVERSIDAD BE CHILE 


\section{$-2$}

Wu, enando estos eanocismientes so hularieur ijte aprovecher dus ventafas, la froblacian

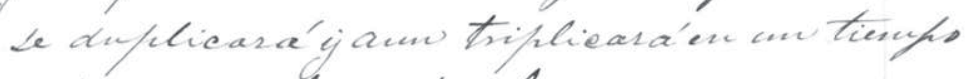
selativamente earto, la fencracian que oc levante dera' fueste i vijarada. De enta manesa questasia resulle $l$ impartante iroblena higienice del amento de la hoblacion de linle. Ivea, fued, a mestos gabermantes nelar for la caluet del inablo, hasiendo oblifataria la enseiranga de la hifiene an tatarlas exevelar de ufúrticas, sabre tiv en las de mujeres. Dor otra haste vemas en ol fuelloque, leo hereviar netailieas, es decir aquellas que trabafan tade la demana idercandan el donnigs, que cancen; duesmendiasianente a horas detesminalas, que no ocembriaginete,

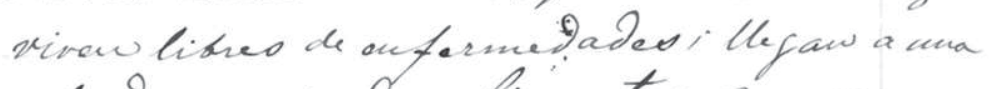
edad avanga ofu, binestar que no

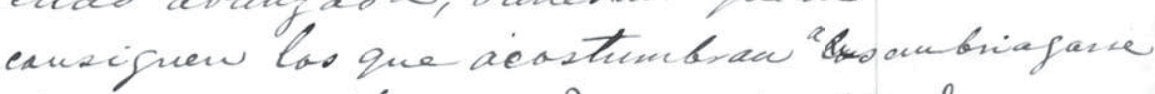
ydamingos, Húnes, a Dormir desabigabs isn enalus quiesa haite, que excens anedia nothe cancid o 0 inifertar, ifurtencule eandinentadao equ a fó, eamo le thandio amollat, unalai a de hata te, runafedas

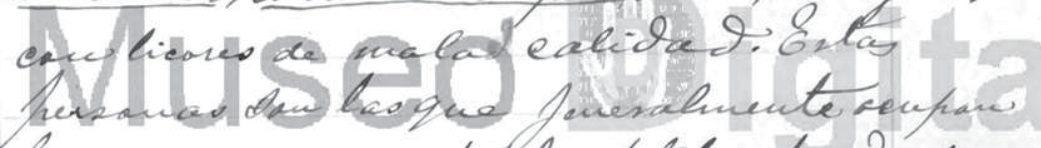

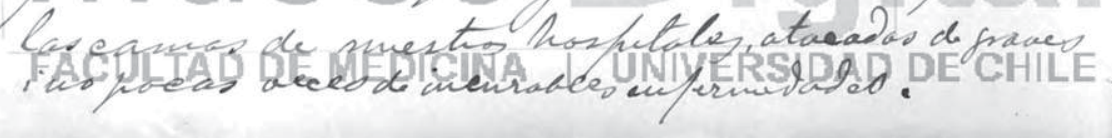




$$
\begin{aligned}
& \text { Dapitulo Legundo } \\
& \text { De la Alimentaoion } \\
& \text { Se Hama alimectaciou, }
\end{aligned}
$$

a las snstaveias que intrad reidasen d a fravale lijestivo, dirsar hava duministras al enurfio del intinduo, los materiales necesanios frara se renoracian, eseciminto.

Divisian, Cos alineutes hue der der aminales, eamo la carne de racas, el queso; sofetales,

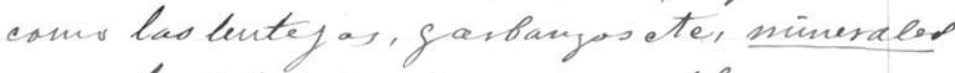

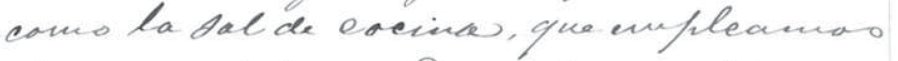
diariamente hara enidinentar meetras eane Das.

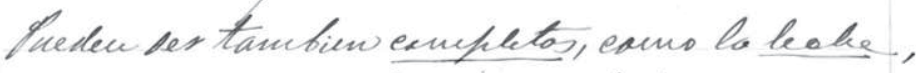
quess elatinento inico dusante los frimesos meres do la vida del hourbe; ineanplets exms la fraca, clayúear te, ean las enabs nopostianus vivis mucho timpe, Dimfres que hicieramos de ectas Dustaneiar, na alinentacian esehriva.

Número ingularidad de las emilas, Entre cada canila debe netias intervalos de eines a bis horas, que sol tim fes neersario hara que termine la difestions. Hesta ryla

dete tenerla eala mo hara daber enaules eanidas pueve haeer al dia. Entre nos atros. se came feneralmente thes a ceept: I desaymun,

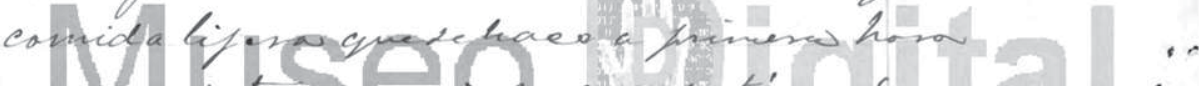

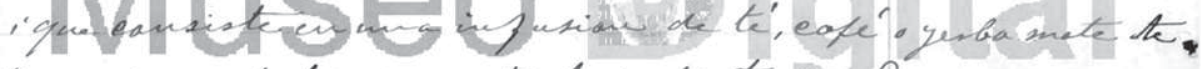

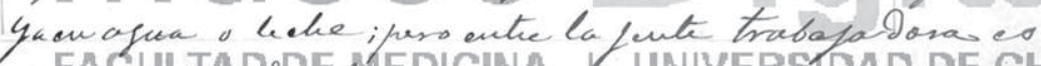

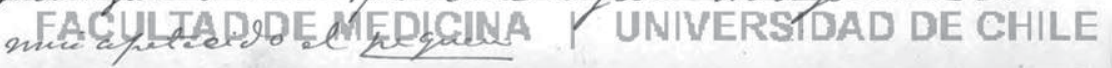




\section{$1 /$}

Sero tingase prescute quela dofrie Dadexaferada, a paste

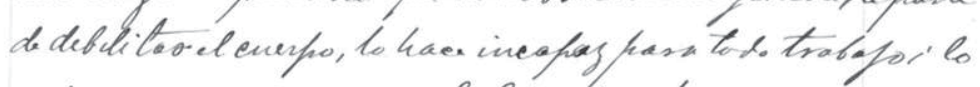

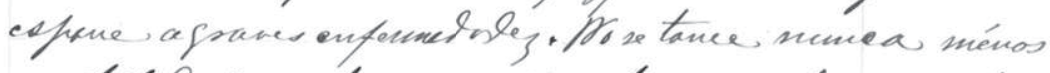
eantidad de onstancian alimentieices que las que el timperancuts indiridurl exije hana mufelir loo reafuction, attigucianes.

Alimontacion foneral del queblo Ohilewo Electudis de la alintentaciaw denn fueblo, som froblema hifienies impostantivims, de las dustaneias de Cus enales hase hes

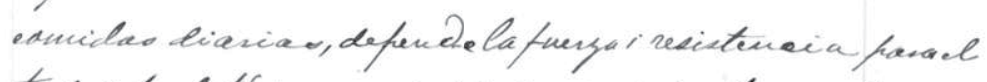
traba fo tautefisico eans intelectral; asi anter nosohas de puede deves dir exaforacions gue la alinentasion

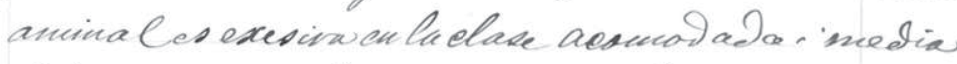
delas ciudaded, la feste úfind ila del eanfo, condune

- hora earne a equsenuneice de la carestia, hos enyo motion no finede hacer uso abudachte de me lumento de

nepracian tau infrostante.

Los llamasos inquiliess delas hariendas, tiencen una

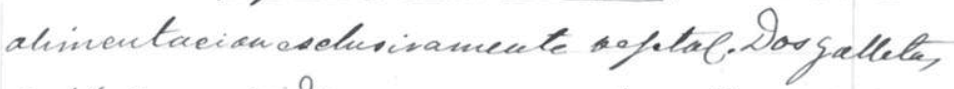

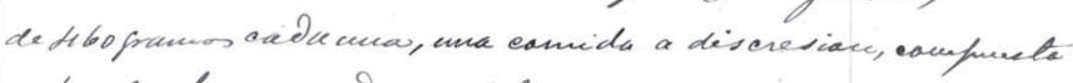

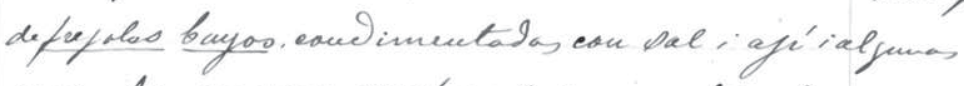
acoes doe ogregan un ferco do prasa, atces bo que forma not camidas diarias.

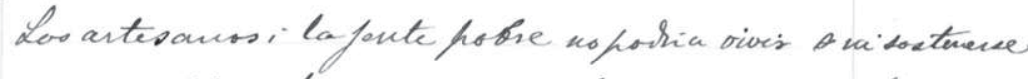

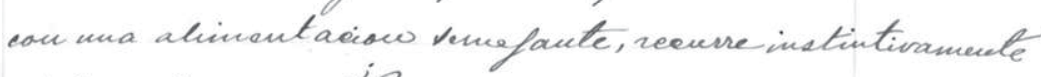

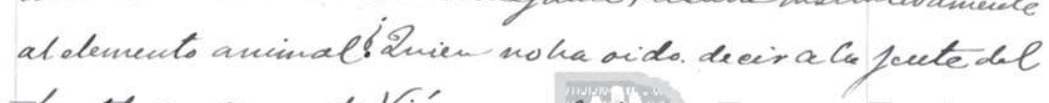

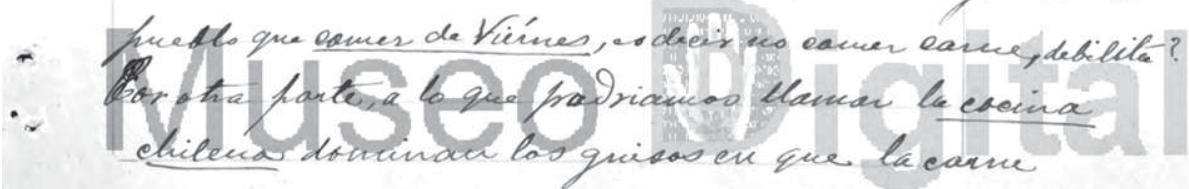
FACULTAD DE MEDICINA | UNIVERSIDAD DE CHILE 


\section{2}

utsa eano frincipal eleneulo; ase; medto hofulas heceherol guiso diasias en tastas las casas maso mínos fudiente), la earbanata,

el charquican, el raldiniau, te. Lo mismo pasa ean el hequar, desaynus hofular que es exifmeeto do Dustaneias vefetale, id la neepor clase de earue. Enter lasdifarentes elases de alimerctos refetates turmos has diferente, lased do fan, bs frefoles lad hapodi los safialle te.

Está porado estadestie aneulé que la earestia de la carue, idemadatinueutas de privera neceridat, influpew de una manera diñecta en anmento de la mostalidatidisminuciou de loo naeimieutos. Loea.fures, a nustros qobernautes, nuevian los incorvenientes que sesultare decua alimentarian dafectussa. La carne, etemento de la fuerza, uns enalidades mutritiras de peudew, de tue eanfrasiecion. eolor, as; las eanus blane as, dau mas fáciles hara diferirlas que las rofas, eeefto la de eleaneho que a hesar de eer flanea so mi mutretiva j hers mu indifesta, Po a to Ias las hersonas les es indiferente, al uss de las sames, a losque se erhiegan a

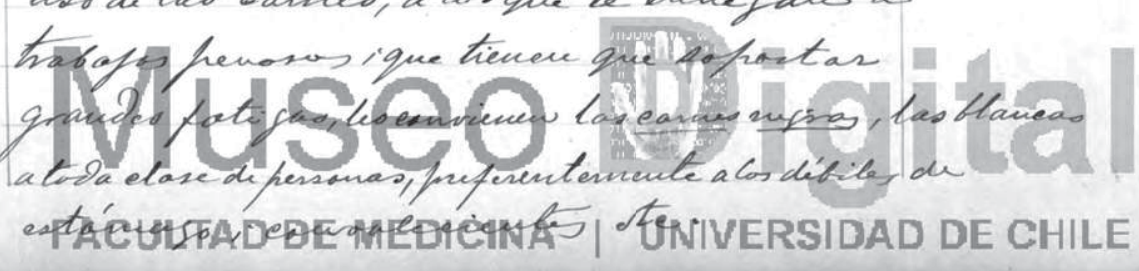




\section{$84+2 x$}

dosmiv, debe obsemase toboslosdias la hrádica dignente: abris bien las purts iventares de loo

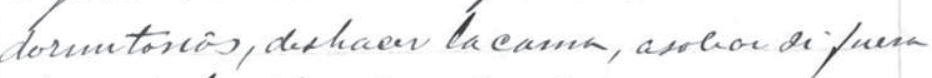
horitce la rofia ponula al cire, are se cansigue que dal gave las manacianes de questabace infre qua ta que tiudent avieiar claice.

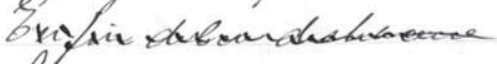

Lacocina es la fiera nas descuidada de la casa, esta'diluata al lats o dobe le acequia, os le mas

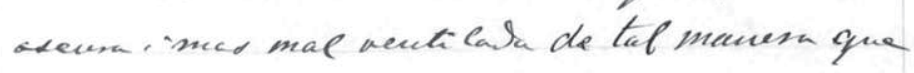
la pobre everiesn a neas de utas en una atróáfere

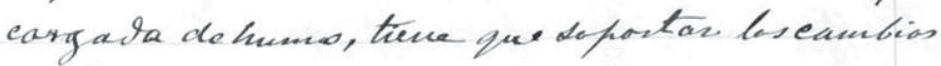
equlimas de temperatura, que le veasianam

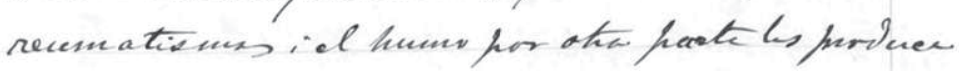
sar la larga un enverenamianto esónieo, de atu. el color amanithut, la falta de apelite que fanalinente trencu.

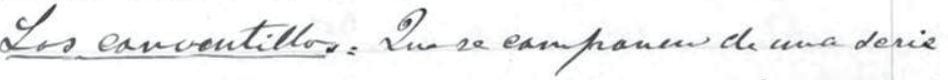
devarts paratelos, en les cuates no se ha equsuctad

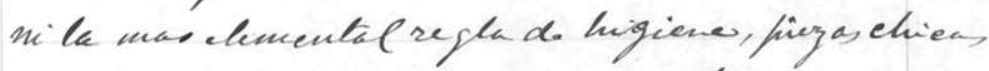
oreuras, mal auctilatas, mudes berenas dande Re eanstruyen los eanuntills dar Herados ean basura. Otras inmuntiaias. Dada ectas eandicianes, la aglomaracian de pente qua vive in ellos; hace que sean mi nial rans,

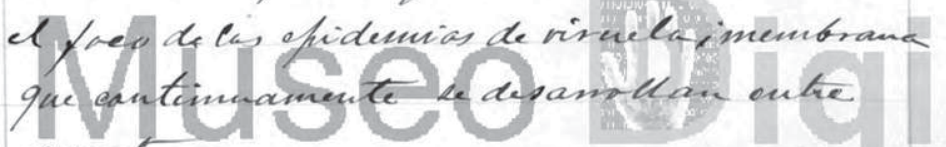
notoliose

FACULTAD DE MEDICINA | UNIVERSIDAD DE CHILE 


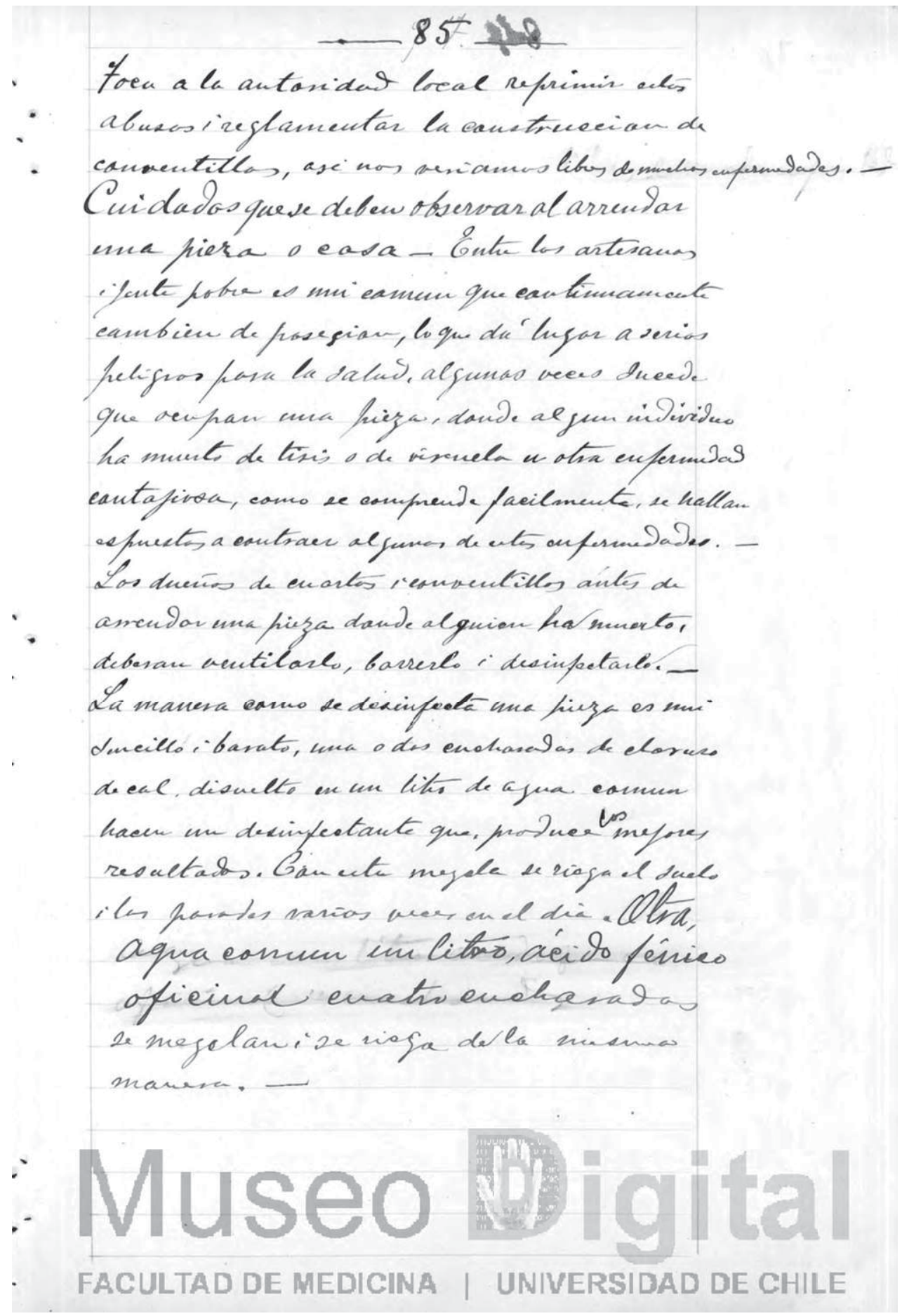




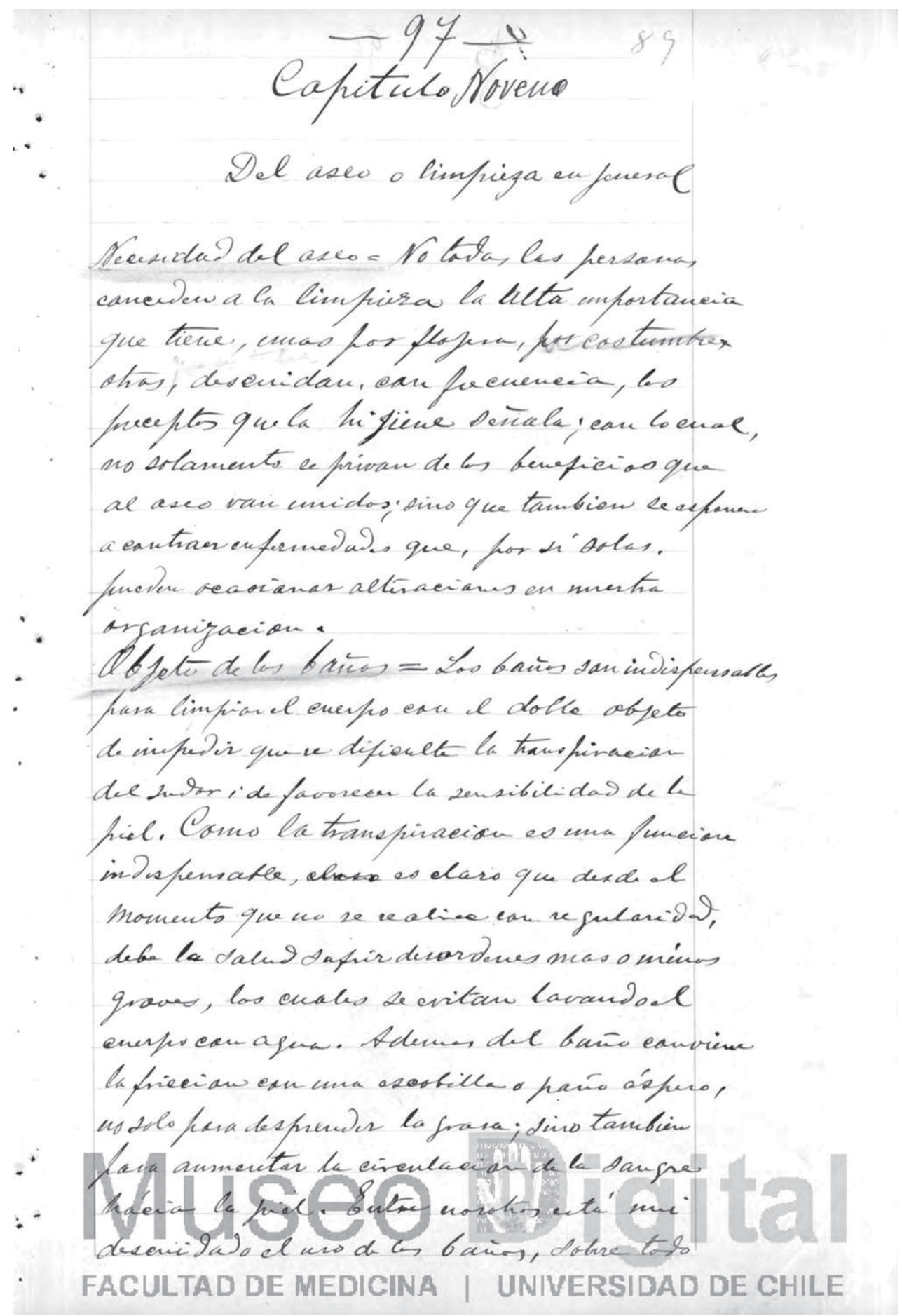




\section{8}

en las sindades ofu no due maritinas, trude

hou'una ver ladera difienetad hava que de fuete

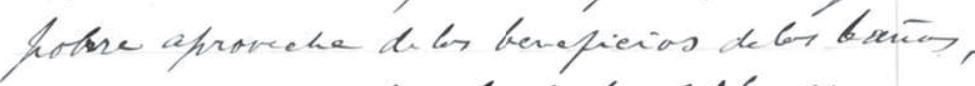

winos naso ois a la fente def fureber qua

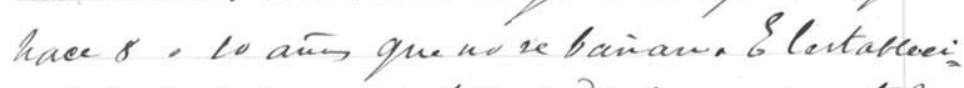

minte de faim grotuitos aindis hemsabe en torda

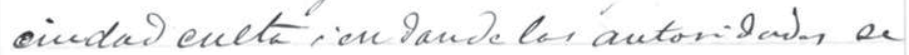

interesaw for. I bienestor del huebor

A mefor hos hova bainese es for la manaua

on ayjmas ; peso enando la hersane so ditiles mi.

envemiante lo hagata nestis dia ma tushoms

decpues del almueso.

bo felignow bairesse en pariss eiremontaneias:

immetiatamentedeefues de osmes.

Cuando resta'subauid de una mavera notable;

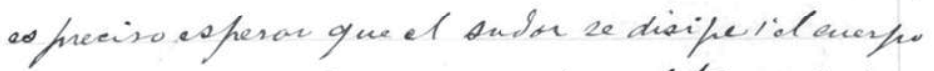

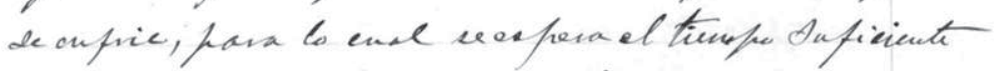
Ademas del larads diasio de la eara, de las mavors,

os mi itit hacerse friceineses al fueko, can un have

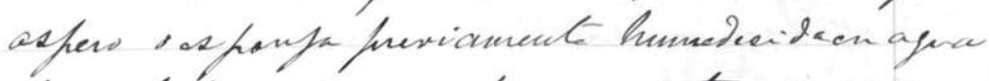
fria, la hosa mes opostunas al timpes de brantane. Las hessonas que tienere cuta buena eastime be

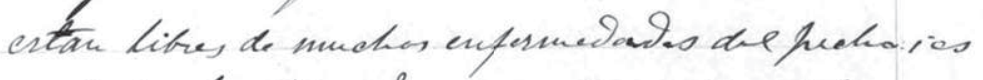
un infrostaule medis hara prevenise de la

tivi frumunar -

Mefluencia de los bavios un la Aatud do nim

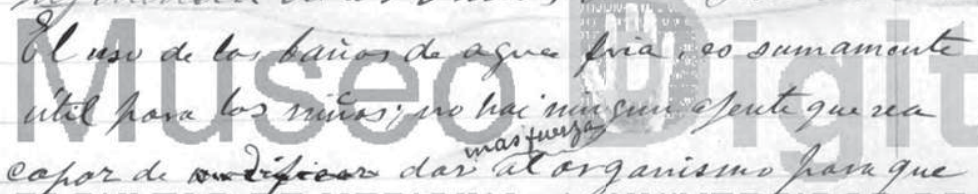

PACULTAD DE MEDICINA | UNIVERSIDAD DE CHILE 
REVISTA ANALES

Séptima Serie. No 16/2019

99

vaiste a bos infersinus refuetions; equvienes

$\therefore$ acostunbrar al niño desde sn mas tierna celad a los bañas fines.

Para acostumbrarle se frimeifia a Cavarles ean aqua las parter, que entare sofuertas al dire, eano dar las manos, la equa. 'A friés;

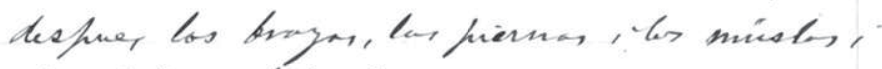

Los ciltimns to d d enups.

ostor lociones se haran muahos vaces for tia

evanto al niño as hequeño fos tines que Gs

orines park de beserencentis que a quedan atheridos al enerpo fno Duzem crevorss:

griens que san tax dolonosse

De la bace. I laser de la bren, as mu-

imfortante hava mantanes denerfeon

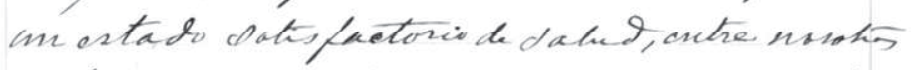
esta' mi descridada enter regla hijienieas, la

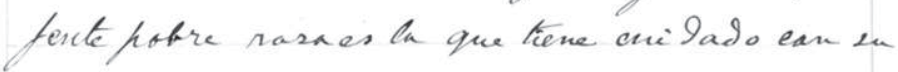
dutadares, de ento resalt que mi járas la

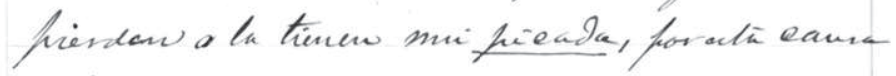
questa cutre los dientes fortienles de cannis a que formentan i.je justuen áeidos que ayuitan la destruevian de cos que frectar actar buenos, dando al aticutes un olor fitido, "desagrad atee. Daraute ha farouters pres ande en fulta fare hacer una buene dijostim, frodge la farsy

- belostamage dufle a los diculsij hers enando

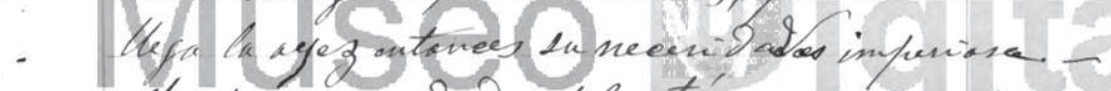
Hudas anfunisades del estomago que nesistow FACULTAD DE MEDICINA | UNTVERSIDAD DE CHILE

523 


\section{0}

atos tratamiente dan radicalucede eusada,

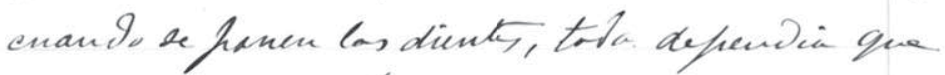
no se mascaba biow.

Lod dientes deben excobillare ma vey for tia, diendo la mainana, d tim fro de acortase la hosa mas a hroposto- Ce usasu'un cepitto

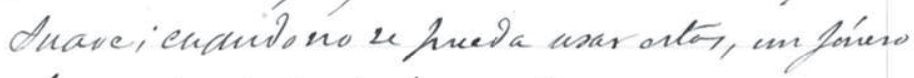
duave Anfle herfectamente. Las fortras, hasts, licases que un unar hasad aseo de los diante, de labaen, noprevardebon des cieilo, etcot forque avidestruyan el dieute den muetra fadikid.

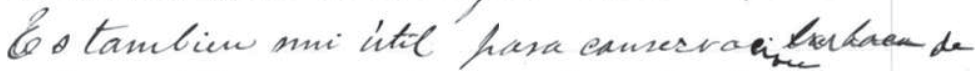

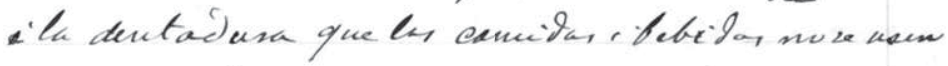
micalicutar-

Eo mifaeil perdes uns mavios dinden, cuando se bs ase hou eoctor, amaneas objelis, destafias

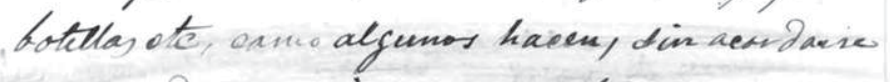

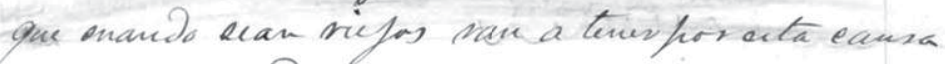
mas de una indifertion. La manera eque deke dacarse la cuncida que

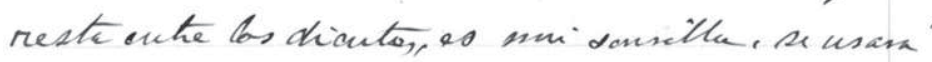
una pluma de ave, bos itthy de metal eamo a gajas,

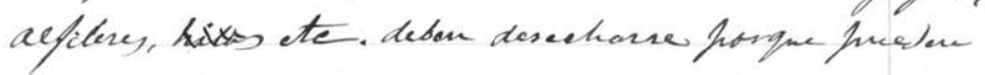
dectries el esmalle exn on dungar, reasianas la pieadura.

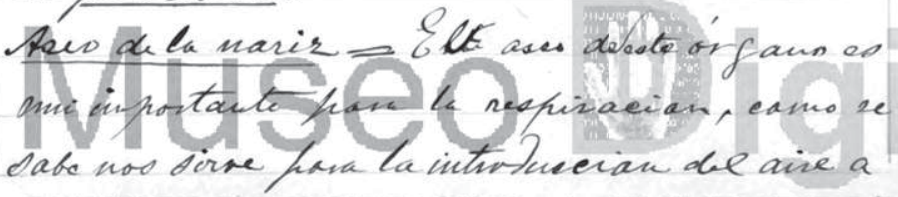
FACULTAD DE MEDICINA | UNIVERSIDADDE CHILE 


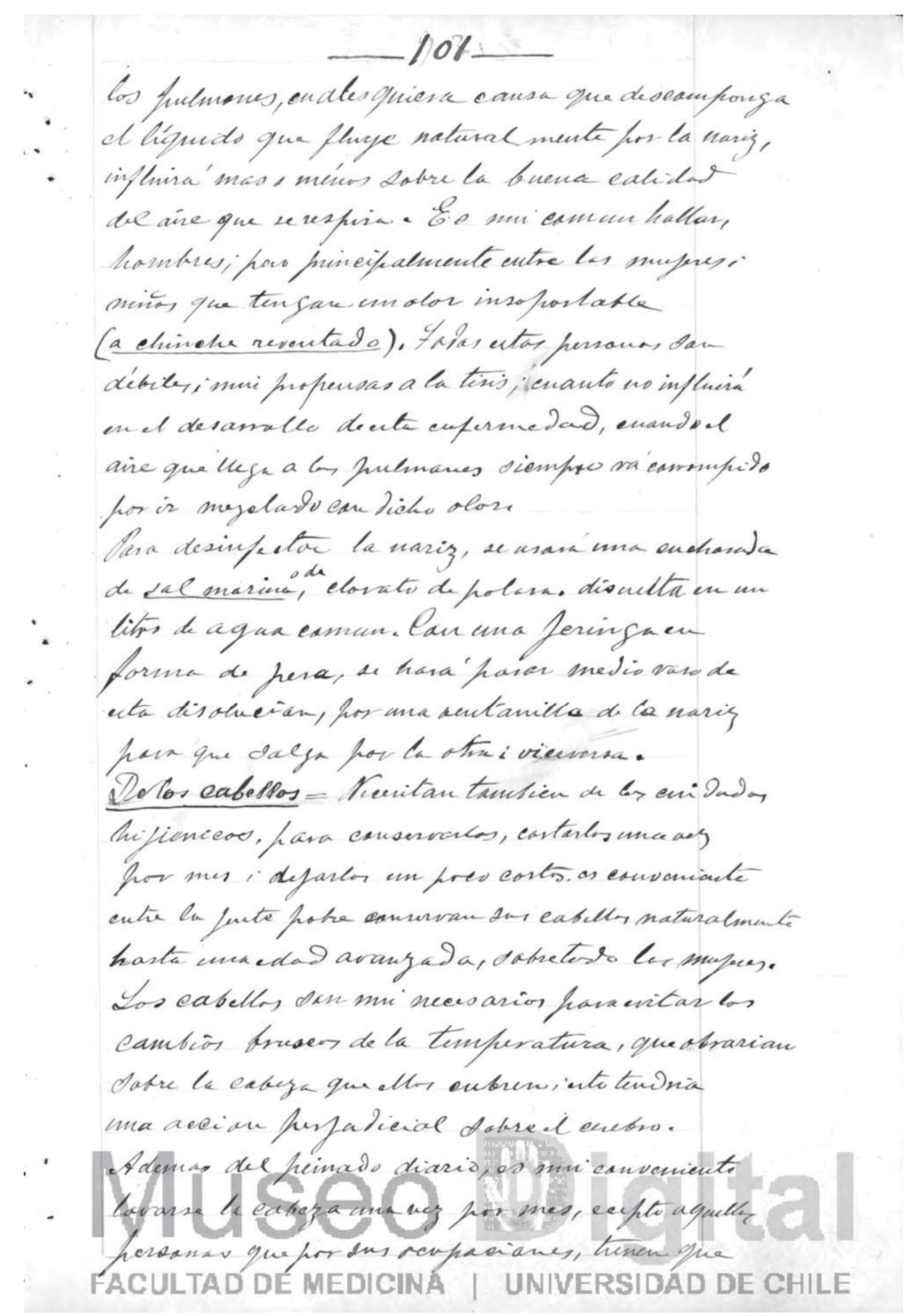




\section{$-102$}

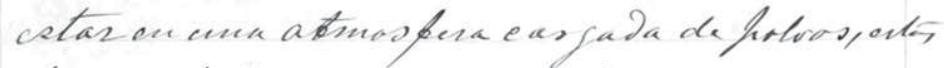

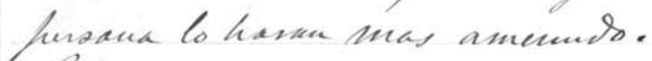

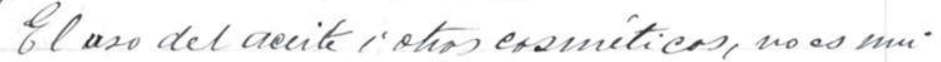

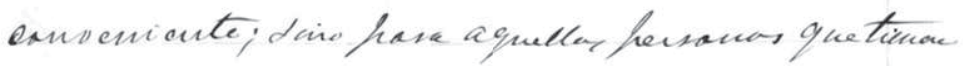

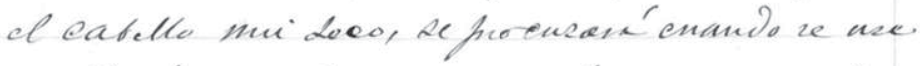

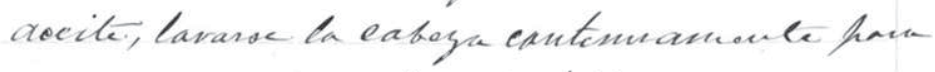

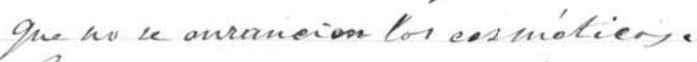

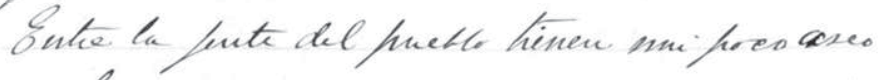

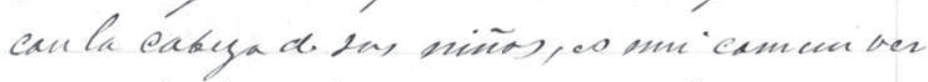

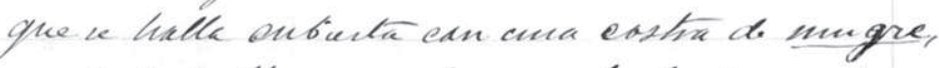

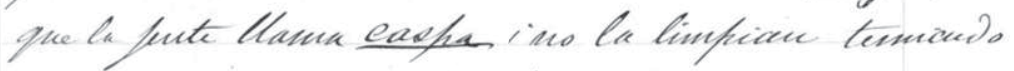

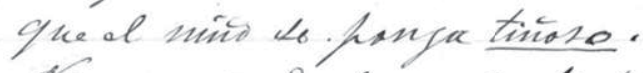

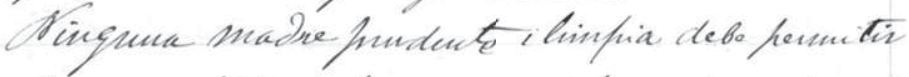

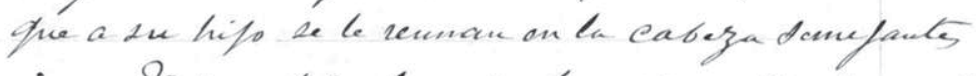

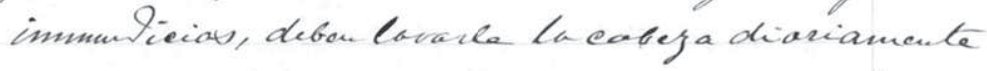

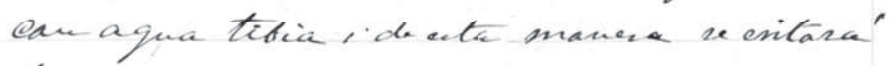

la astomeravin.

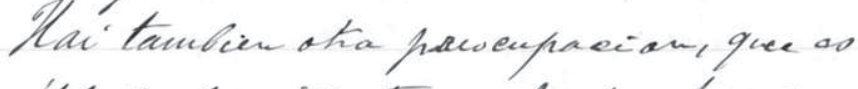

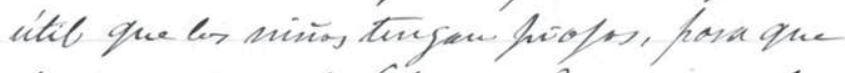

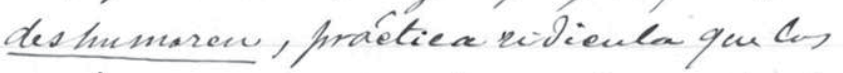
madieg deber evitar hor medis de la kingirya.

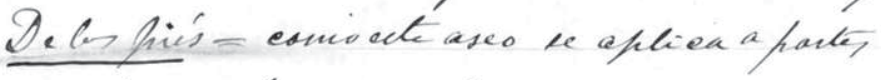

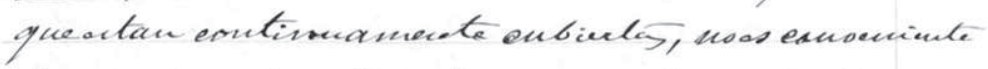

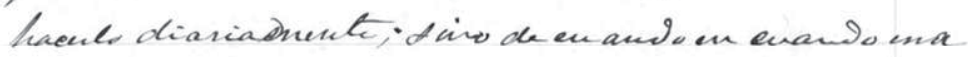

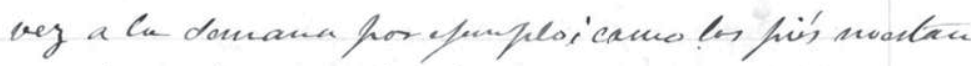
acortuntiabs a recibir ta infresiow del frio

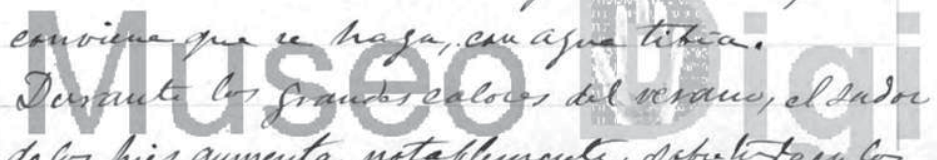

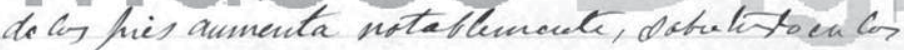

FACULTAD DE MEDICINA | UNIVERSIDAD DE CHILE 
REVISTA ANALES

Séptima Serie. No 16/2019

$103+1$

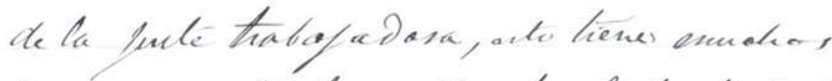

$\therefore$ inconvenienter hara ders, hasta las infide

trabajor, aun autar. Sucerte que ol dndes

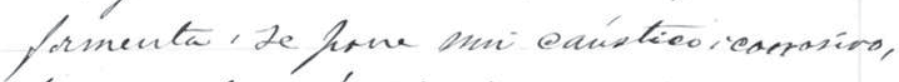

ls enees loo friés iproduea griels que san

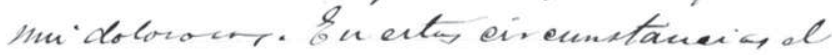

larato de les hiés diasiameute, se haves

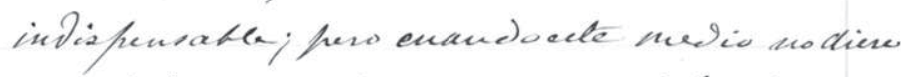

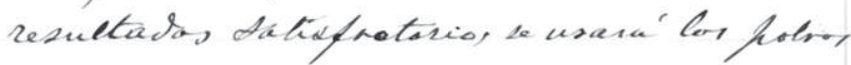

Aignents.

ench freedictada unu enotrasaba

ethuntre aufutis is is

taleo dofaneia is is

Aaido dacieilies media enoharadita

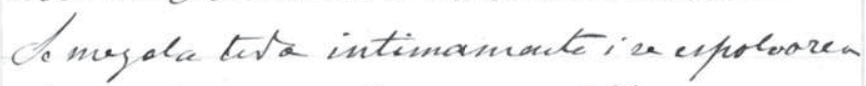

al eagoss can metir enchar itta do a to megela

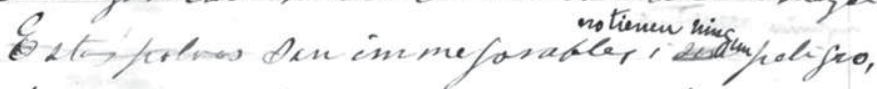

havequitor el mal obe do be fies, daw de ordunanga en el cfercito prusiano.

Delos Cosméticos $=$ Man surtanciar que

abrar sobre la cubiula entánea, ernal obfet

de earseroas ens endidades, remestias las

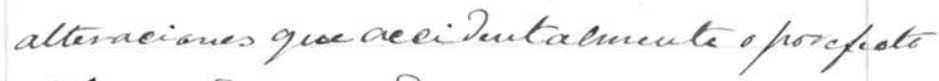
dela edad se provujean.

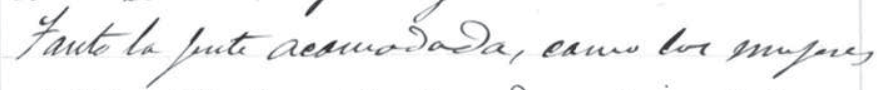

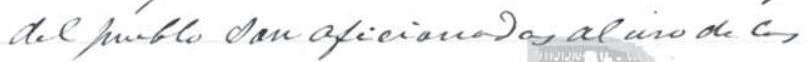

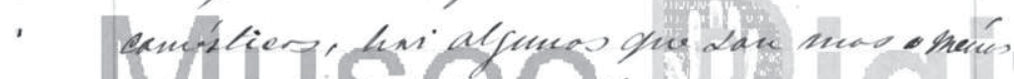

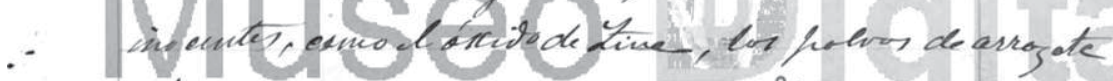

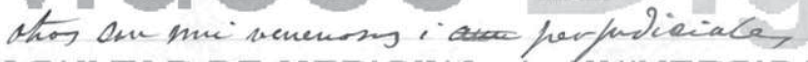

FACULTAD DE MEDICINA UNIVERSIDAD DE CHILE

527 


\section{4}

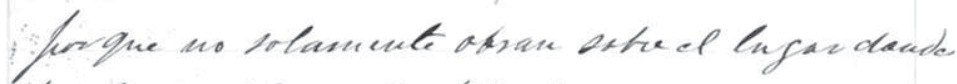

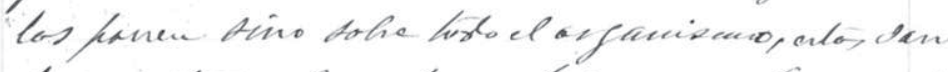

losque tiven hos bave $d$ mesounio (agogue)

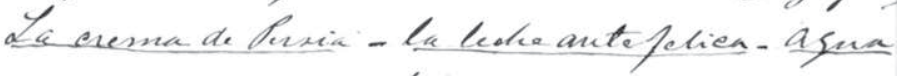

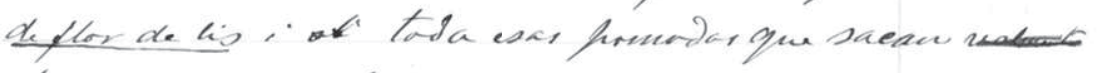

las munches de la casa.

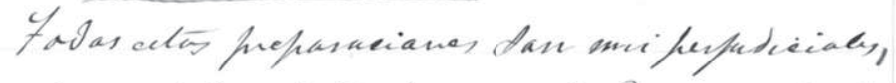

ademer de los afeator fenerabs, froducen mue olos

A la boen, inovoean la eaida de las diucles.

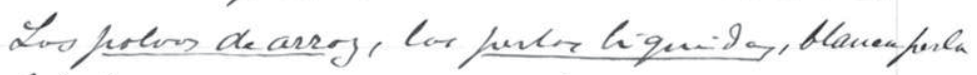

(óxigo. carbanato de zine), las cameliaras, d

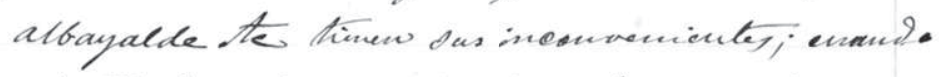

ectos folvos dar pueds botre la cara, puoulo

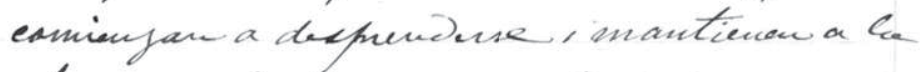

forsana vosterse de una atinósfora do foloos

que pruede es nurs a ménes nocion segun

Lea en frocedeneia, datulas setis

muferes ectan hrofunses a la teses.

Laesperioneia de bestas las tienfers hafurvess

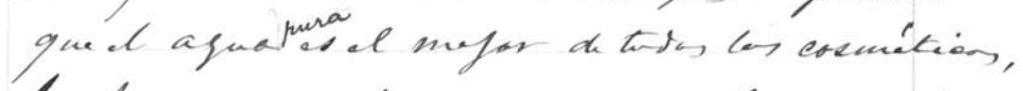

las fursanas que la usan eruservan el sentlante,

din arrugas. havla una odat. que no spesiguen

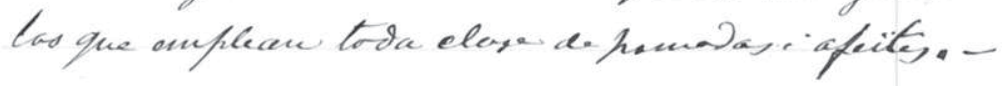
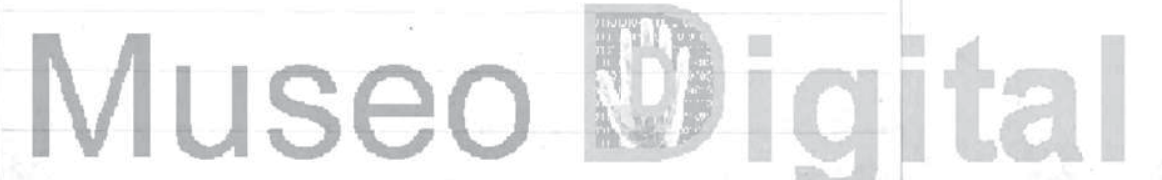

FACULTAD DE MEDICINA | UNIVERSIDAD DE CHILE 


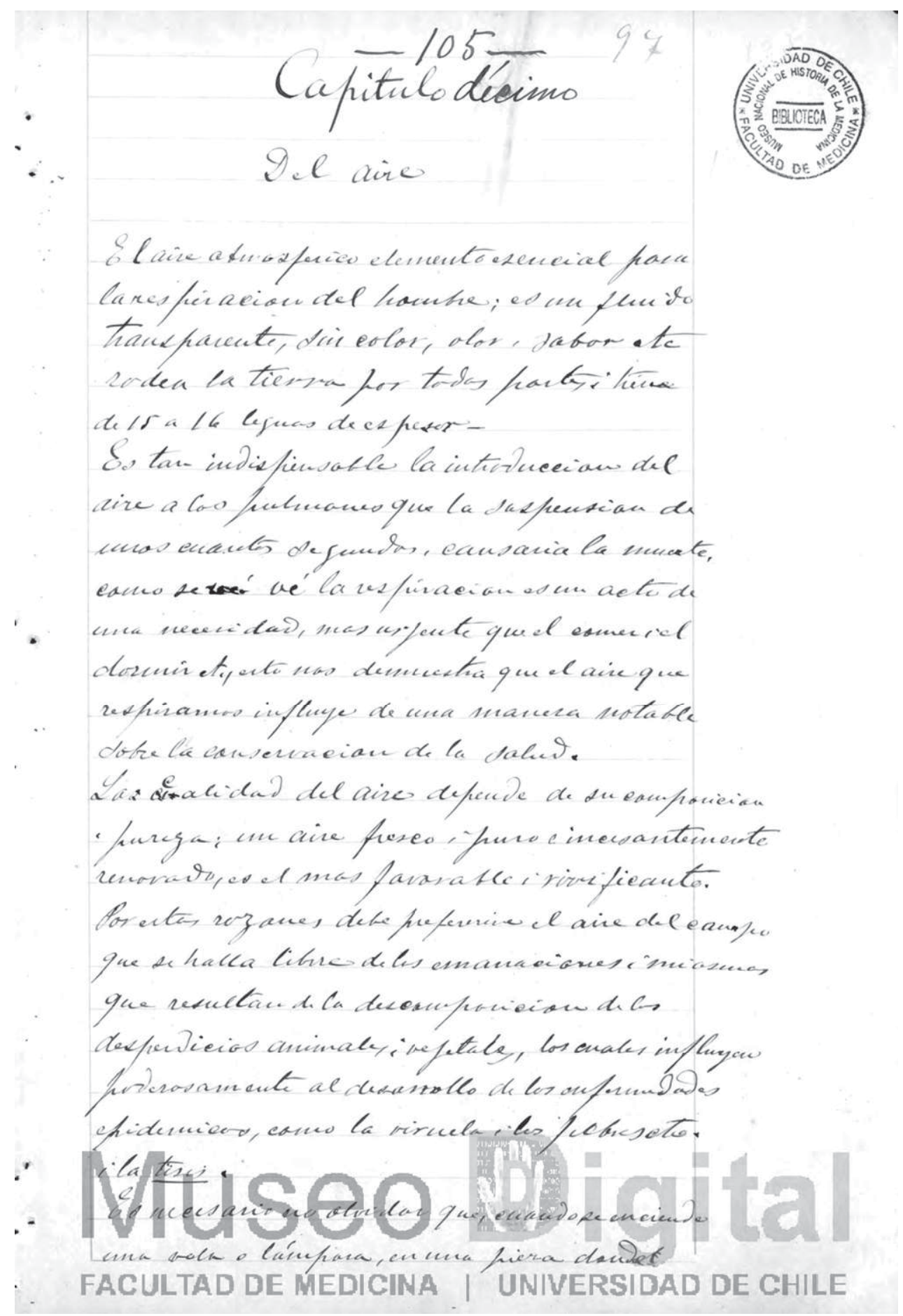


DOSSIER HISTÓRICO

$\therefore \quad$ Cafitule déécims enarto

De las desembarazatas

Thejinew de las desernbaragalas = Los enid ados que se debe frovi i as a una desembarajala, de nefierew a la habitaciour, a la carna, a los alimentro bebidas, infresianes morales te. En meste queter hai mucho quo innovas aute respecto.

La cama. dube star eolveala on una fiora bostante offreiosa, ventelada ino m cm

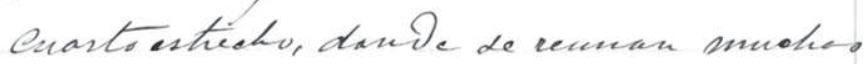
hersana 6.

Loserfs de la carna deberanetor mu limefios \&l aire dibe der renorato contimanente; hero dese mantonere in inatemperatusa morasa.

La comit as, entre mostés necuiter una déria reforma, duante los frimeros dias $a$ bs du' calds de gallina, apenes dize bes hermite eamer pans. Lavegla as que lata mifer que desémbarace dete alimentane biew, bumos biftede, qallina asala, lede, tucerro fosates for aque, francte. Bum vino.

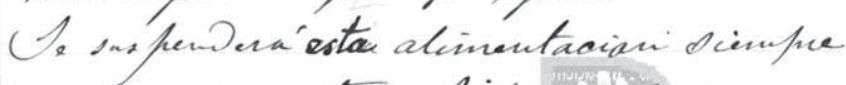

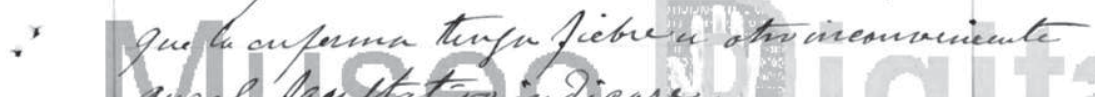

$\therefore$ Yued facutater indicase.

Betivos. E lagur fura terciala can un buen vino

- FCULTAD DE MEDICINA | UNIVERSIDAD DE CHILE

530 
de Gillan,eo mideonerviente, onto no lo tomará

mi fir sciro quitato el hialo.

Mmpresines movales $=8 \mathrm{~d}$ min infortante

manterer a la cuforena on la mayou tranguiles as

mosal, nocantales bo ducesos del dia equose

Acostumbre: critar loo lasfas canversacianeo

que la fate gans

Pow lo que numea de reamendara'bostantes

no permitir las viailas de anifas, veciuas'

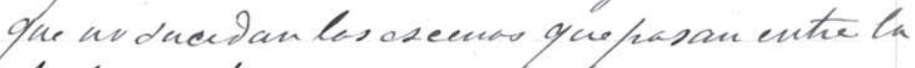

foute del huetlo, una vey que dabou quela

fulama ha desonbajalo, van a felieitarla,

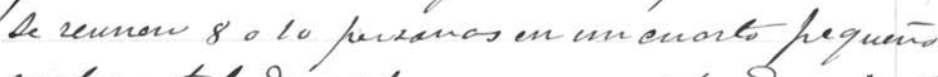

mal voutalas". have moger abuntaniento

cimaw la fucerta hava que no la de cive a la

enforna, fuman, exwaryan de tora, de orte

manera le dan a concer sucesos of ue fuceden

to dar ma noaida a onvenenoia

de la impresion.

Aa rearla, es una nformet at mifuligarea."

santafiona, que tione for mineifuc sauza he

desosmprivion del aives asi ar que la linfiega

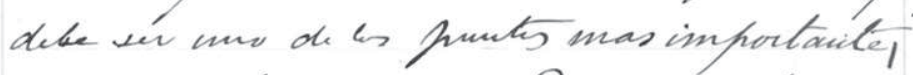

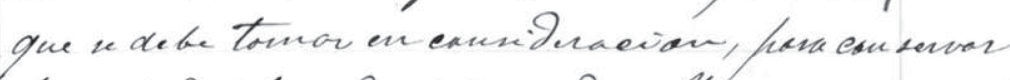

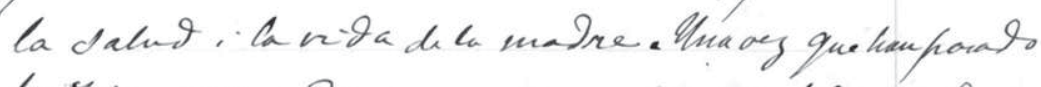

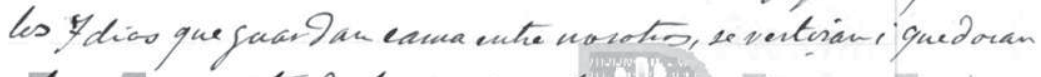

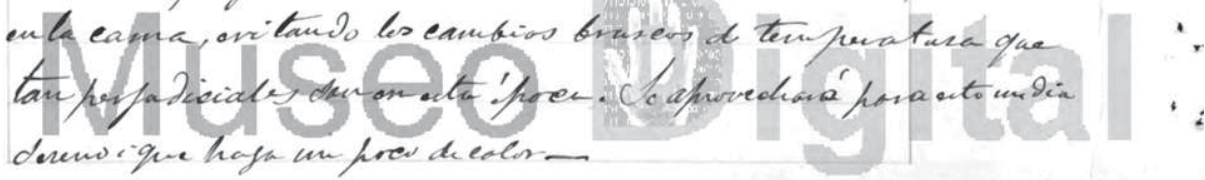

FACULTAD DE MEDICINA | UNIVERSIDAD DE CHILE 


\section{Capitulo decimo quinto De la tisis}

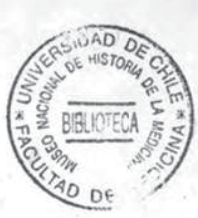

La tivis pulmonar = bo una de las enfounctorles maseamungen Chilo, de lal manera que mas de un of for eciento do bo que mucrew dan tíxieoo.

Es mas camun cu las eirdades, dande hai aglomeraciande foucter de neffira ine acice infure, de came mal det, que on lis campos.

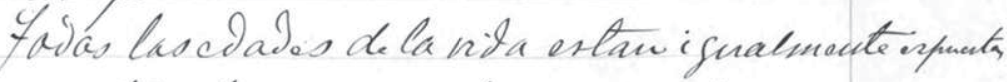
Acantraerla; perven la fureculut, e. excosivanente eamin, es mi rara en los niños miñoses de un año ich lines de bo años fram adeloute. La pente hohe idobetists las muferes dar las que jagan mayos tribut acita temile oufumed 9 .

Algunvo oficiod ipreferianes prodinfancer a

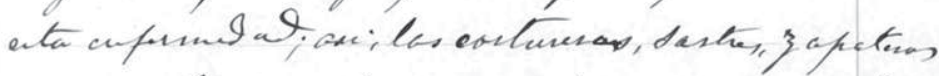
que para trala for frasan eand enerfu inclinalo, los vordedovesde conban, de eal, lana, los fanaderss.

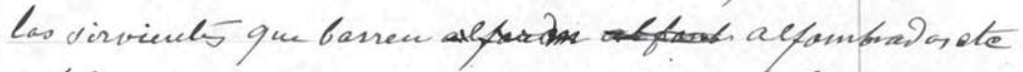
itodos aymelos que uxpiran un aive earfadoce

\section{$\therefore$ kocho.}




\section{2}

la enformetal Lamata exufades

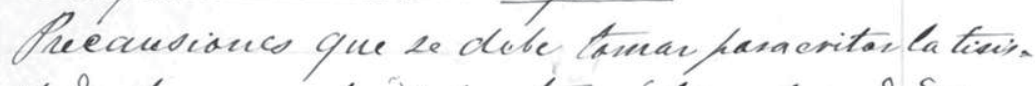

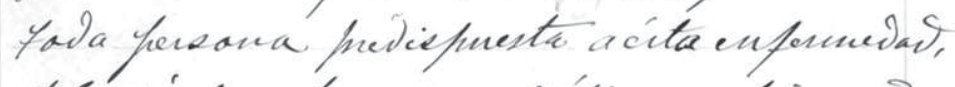

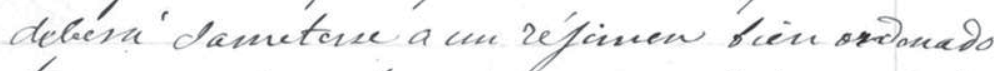

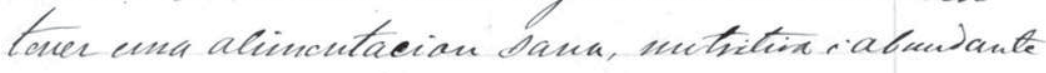

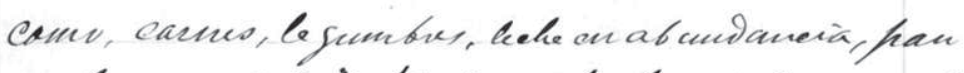

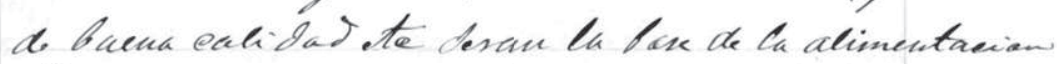

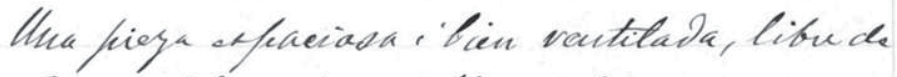

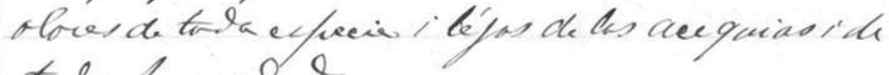
tada humetas.

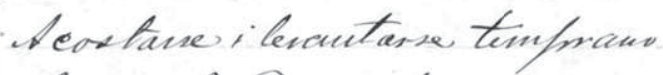

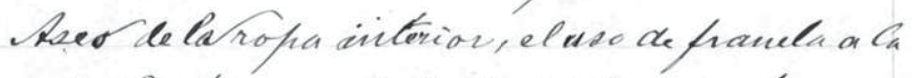

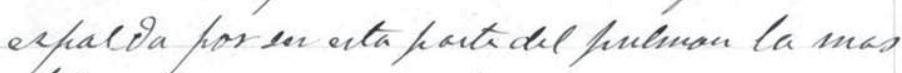
Laiel han ser atacada.

2 a cama, nui limpia.

Los haveas al camplos, a los quints de vereed a las

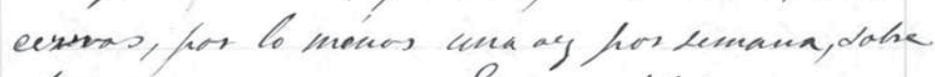

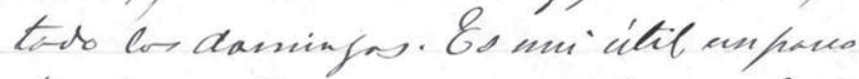

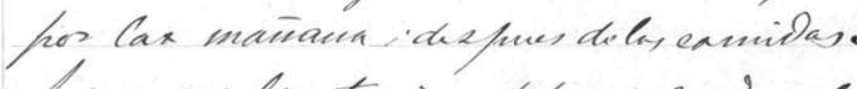
Legun en la entaciour deceran grasuar eas

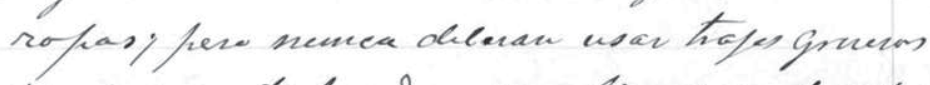
iesusivamente fesados; snas bien dedem habitanse a dofortar las in timprevies.

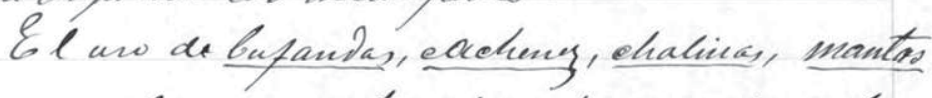

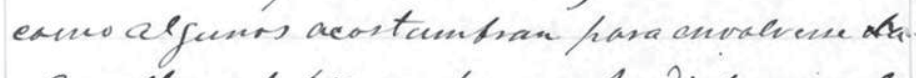

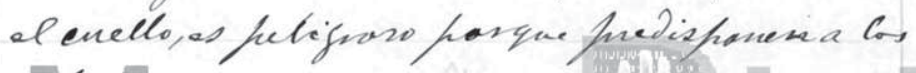

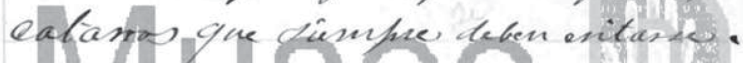

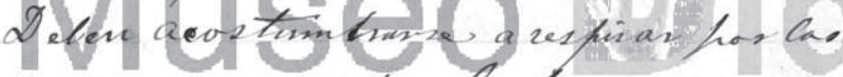

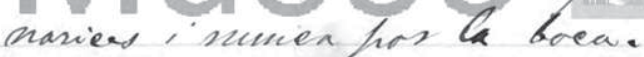

FACULTAD DE MEDICINA | UNIVERSIDAD DE CHILE 


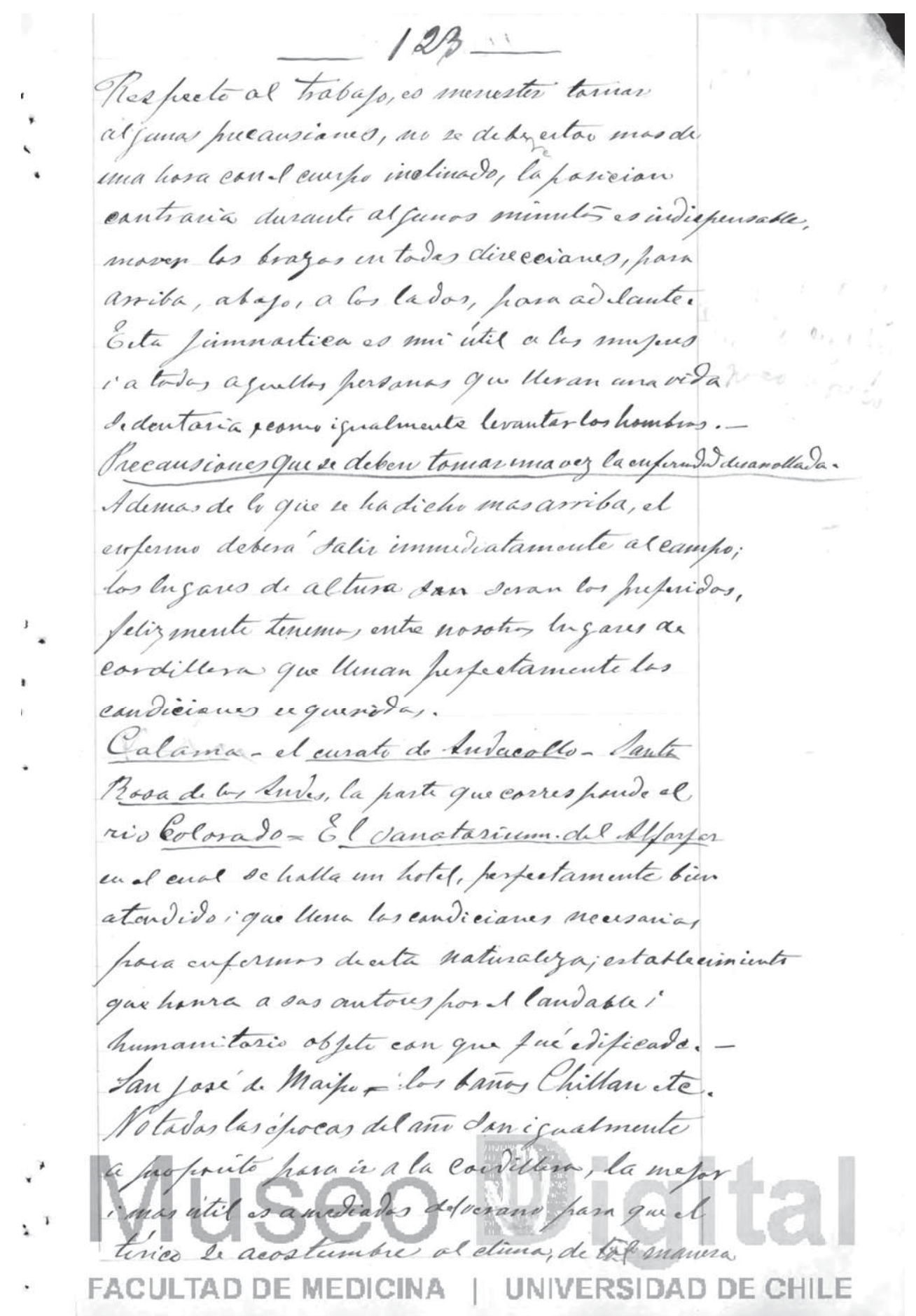




$$
124
$$

que enando tlefuer el invienes, ya aite' aesotumbanto

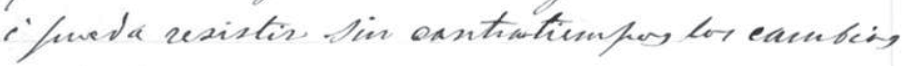

de temperatura.

Hai una frecearsian, que es noevsari tamas in

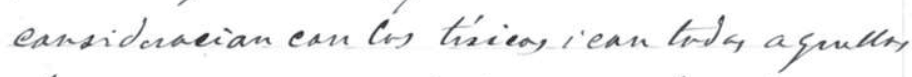

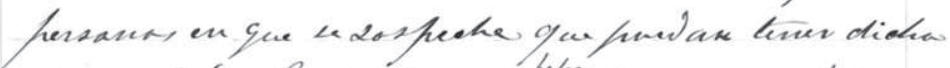

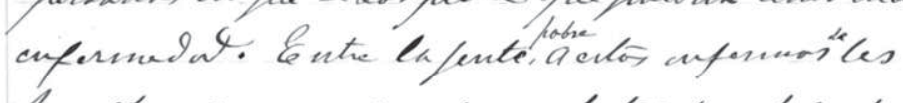

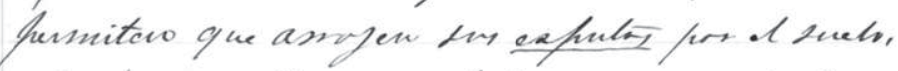
ihasedes, din fifaree enol hiliges que eato tiene. hasa las persanes que habitas o habitaran mes

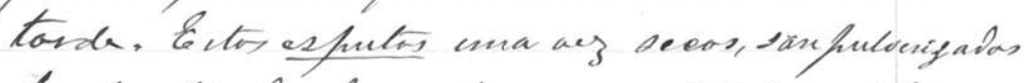

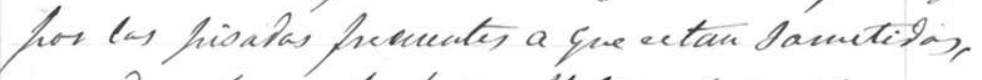
evando ze basne la fiery a, lltavendaize, irasan ean ente a loo finlmanes, is la fursana que reeike la demilla de la tisis esta' dekilitada fou hrov timfos deafues sera' un verladere tisices.

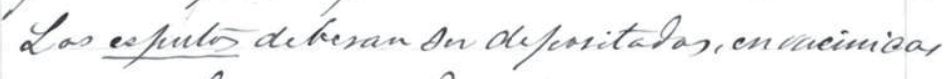
voenpilesas, enande se trate de assofacesse

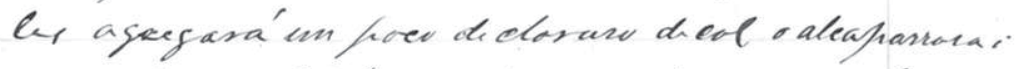
a fua hirviute hasa destrui decta menera la profueted cantafixiad Cos exputs.

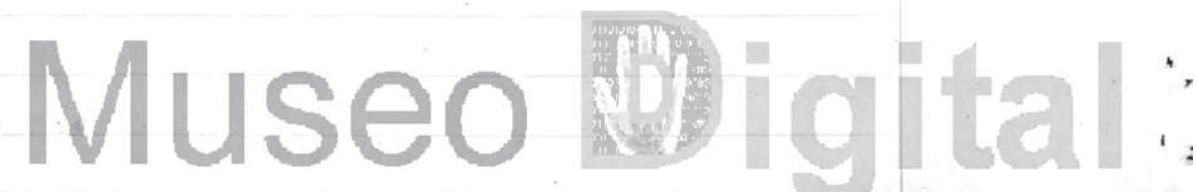

FACULTAD DE MEDICINA | UNIVERSIDAD DE CHILE . 
Cafitulodéeino-de plii.$$
\text { Higines moral }
$$

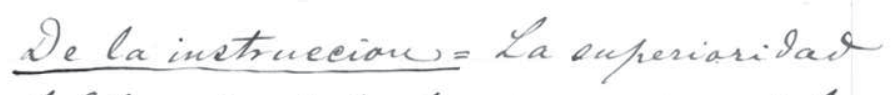
del hambre sabre los dencas seres de la reasiou, defrende de on sran desandelo cesebral. Me debe efercitas cute órgano - tender incesantenente a a grandar el eírenlo de sus ideas. Giste bullo resutads seconsigue hor metio de la instruceion,

- Lestudio deberá des oiempre mosterado ies necesaris inturuprafinlo enando la fatiga eamienee.

La enetura del es hinctu desarralla tasas mestras facultades, la menaria, el juieis, Inaciozinio te, cleva el alma; desanalla los bellas dentimientay, annoble ev al casagan idirife mestras accianes en la via dal bien. Nos hace bunos, iltile, iquesidas da mesters demefartegi estresher los lazso can que ectaw milas los appososiles hace dar ma bueves - Oncacions a sus hijas. In fin la eneturs delesfiritu es la frente de ma inuetitud

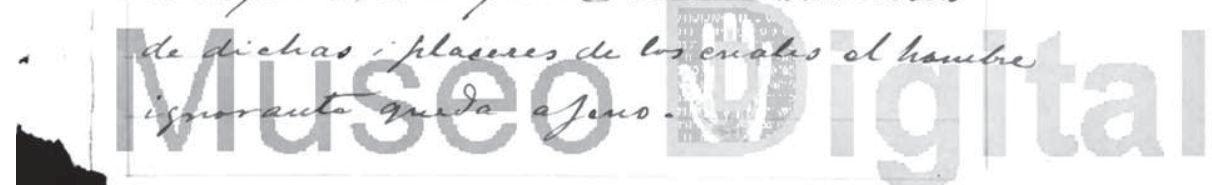

FACULTAD DE MEDICINA | UNIVERSIDAD DE CHILE 


\section{8}

Dela leetura ielecian de mu hibro $=$ El qusto for la hetura se va' desamallausto de. una manera notable en el jueves, ragan for la cual. co necesaris indieas un mesis que sirva frara la direceian ordenada de taw infrostante asmets.

Mnchos industriales alhagatos for la eepeetation de la fanancia, wo hefi lan en remitio a las cavas, entregae de novelas do hacrtilla, ilustratas ean láminas de mudros eoloses hara Clamar ari la atemsinew de los incautasi en feneral dichos hibras cavi. tabas timen los mismas asfumcutos, las deserifeianes dan lasgas, cansastas, cano que les canriene que la novela dalga can el mayor númers de entregas. Ladecciou de me buen libros mini infortante

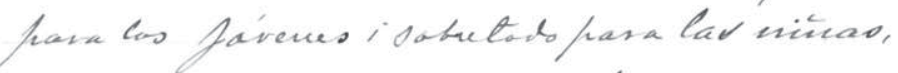
nodebran daveles el finimer bibro que se presente, las faver dearaw vijilar ean enid ado frovque al no haveuls asci, esfanew a kns hijos a que Re llenew la eabeja can ideas estravagante. ce ha visto que, in ess fraices donde ce aesstumbere laketura de atw olase de abras, 20 ha eanutids esimenes en un toto pemefante, a los referilas and libso, un libis quseritigne fas costumber

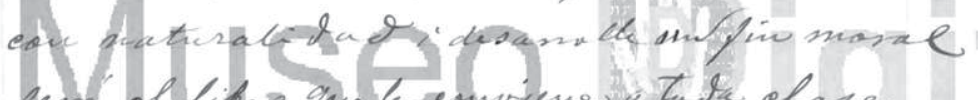

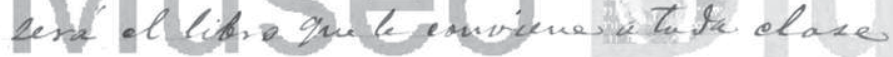
de herpeciso. UNIVERSIDAD DE CHIL 


\section{A tarocinothen} ahorros tienew nna influencias direola cobre la salubilat fúblicas, so dabe horitivanente que la misesia ammenta la mortalilas, las institueiaues de aleosos dan feneralmente hara vecidir las pequeñas econamias de la fente frodre, frava habdiarlas a pensar en el dia de mañana, tar desenidado ente nosotios, de enta manera en eass de enferme dat, se eantará ean secursas fara contrarestar las fenurias en las momoutas deseasey que inindabecmente inflnyen tauts dabu lo finies, moral del individus.- Par otrafiate la fusena que ve habitua a eeonanisas tiene ase guraso du fiarvenir, di. tados mestes asterauss eamprendiesan la infhencias, al fastisto que ze fue de dacar de ma libretes de la eafa de ahormos, enes no habria curo dolo que no 2 a presusasia a haver depóvilos. Mpongare que mantesans fuera drepedilo de an talles, si habia cernomipads ten Dria reenssos fara manteres a en familia, naila tursian que onfrir, on al eass eventravio a enantas frivacienes no los asfoustria, no be quotaria otro matio que neourie a las casas de ejureia Dande

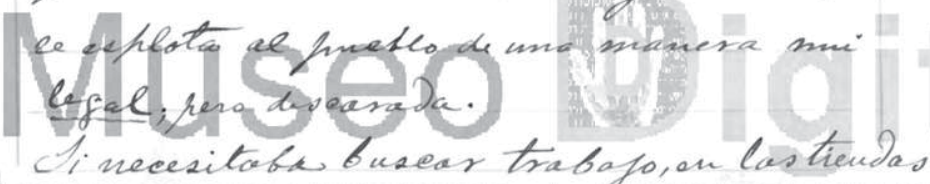
FACULTAD DE MEDICINA | UNIVERSIDAD DE CHILE 
lexifirancartas de reeamentacian que

aresitew oa honarabilidasjique recamendacien

Deria Dupesiar a una likrota de la eafa de.

ahorros que, ademas de upusentas una duma

de diness, daba maidew de la mosali las

de la fussona a que pertancecia. Go inivida

que l que ahora, ticne bucuas eastumbres,

en ma falakia, es una hersana de euya

moralidad no le puede Indas.-

El quego $=$ La hasion del hogs haverde

del deseo de hacuse vies, din queses trabafar,

es tar dañosa have la daluct; eamo hesfudieial

lacala dreiedad.

Entre wosto ha lle pado a ur ma verdaclesa

hlagia, desde d vies hasta el ulltine pobre be

eanfelaceren haeer a fuesta, los mos

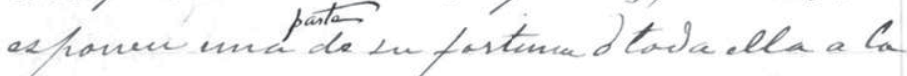

lijerega de me eaballo, los atasel trabajo

de ma semana a la hinta de ma earta,

duce Diendo muchas veces que for ectas eausas,

lar familias quedan div nemeas hana

stender a las necesidades mas wyentes. -

Las sesultadas dobre la salud dan notalles,

la sobrexitaciow nerviasa en que se mantiene

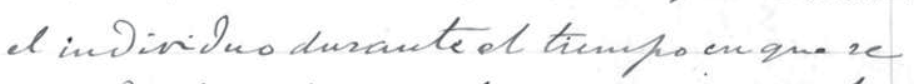

deeide la afmecta, basta fava defar hullas

que ofurna ventadena earra detilitant

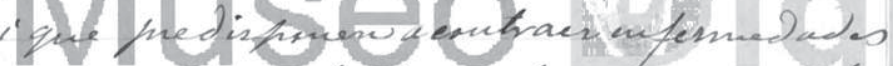

del earagni, la tisi, lawefer mematurate.

FACULTAD DE MEDICIŃA | UNIVERSIDAD DE CंRTLE 


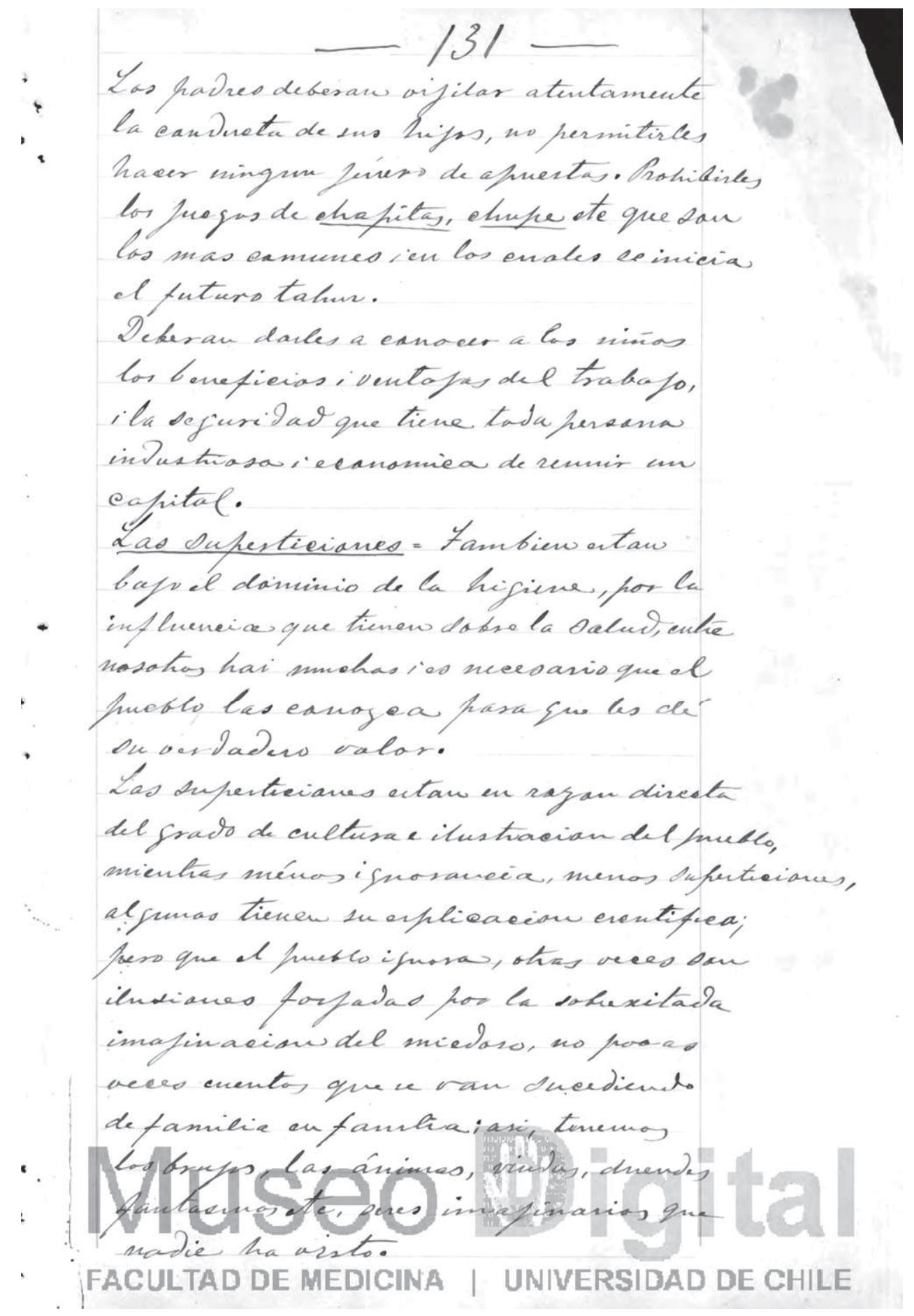


Gleobcols = Lon lanchas machas que

en la eforea del celo yumbaw de una manese

especial; peso quecs eamun a los sosdares,

eicateognieras que sherve rira' que las enjes

Gritan dele misma masto.

Cabila la eansa de ecta dufuntierions, no

tiene sagon de zer la evencia que, el

edoedo se came los escuprop proveriendo

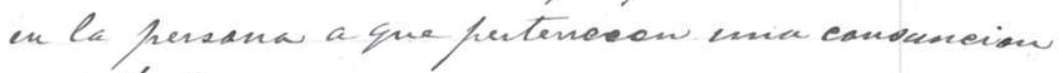

montal.

Gl bacilises = animal imafinasis que has.

jute que ene que modnoe la mute fres la

minala.

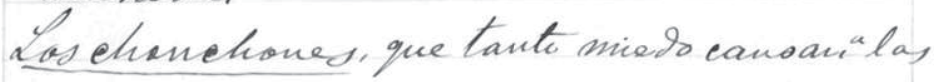

foutes del eanjer, no dins aves acuaticasoge

enigraw de un ingar otro dusante la nadee,

sobiet do las de huav; como gritan de enausto

en onanto de aquiel arifow deceta dnfuctecian

tan estendideren al pueds.

Laseandelilles = Man faces que timen la

hofietas de encenderse es hontaneanente

el eanta.ts del aire, resultaw de la desernefosicion

de los Ineisos, for acta equen sur tan esmunes

en los cementerias desfones de las Ltuvias,

Canco la ky es mi tinue, sesultaque,

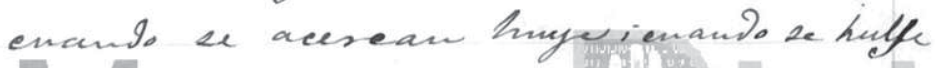

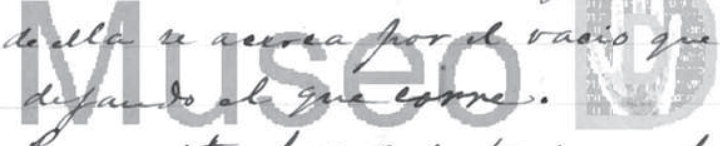

Para evitas las enperticiouss los hadres.

FACULTAD DE MEDICINA | UNIVERSIDAD DE CHILE 


\section{$-133$}

- us deberaw hesmitis que a ano hifastes metan miesto cand enca oll diakle te, nique

- les refieraw enentos un que las fifautos, enanoste, hagan algun hopel. Parque atas namaciones se fravau de tal manera en la acia ingfinacian del mino, frava us bomase famás. Paseos eamifesties = Entre mestra fonte hobre rara es la fanilia que re

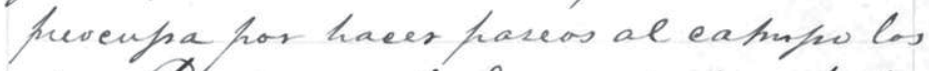
diar Domings, diendo que dichs entretenimionto a suas de res higivieo tiene muehas acutafas que debieraw afmovechar la pente trabafadora iciabretas

- Los vinas. Casno Datemas, seefirar maise huso, es de una necesidad imperiaon fiara tada elace de hersanos. totol munto equece ls eambias que se experimenta en el arganismo del que acostumbra a dabir al eampro; dindo el aire suas huss, time ma influencia esfecial sobre el estámags, fror exta ragow .l apelito se ammonta, is halla a fratable la exnida que al dia antisiar causaba avessions. Los huemanes inglueveiatas for al aire hurv ibalsámies de cos eamfos de hace 


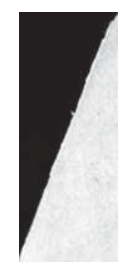

\section{4}

trabafadare hieusw outos hasea, tensian t vent la de oritar los atras ventajas. la de evitar los comprominas que le hacen los amigas de is a semolar a la chingana, forque llegando oansalos - l sueño los obligaria a veoferse tinframo; de manera que, al dia dignente se lesantasia mi de mañana fara entegasse meramente a Ins acu fratianeo. Los benefieias sesian inmenses, tauto Rava la talu Pieamo hor la exomonia gue pradueisia el no haser "dan Limes".

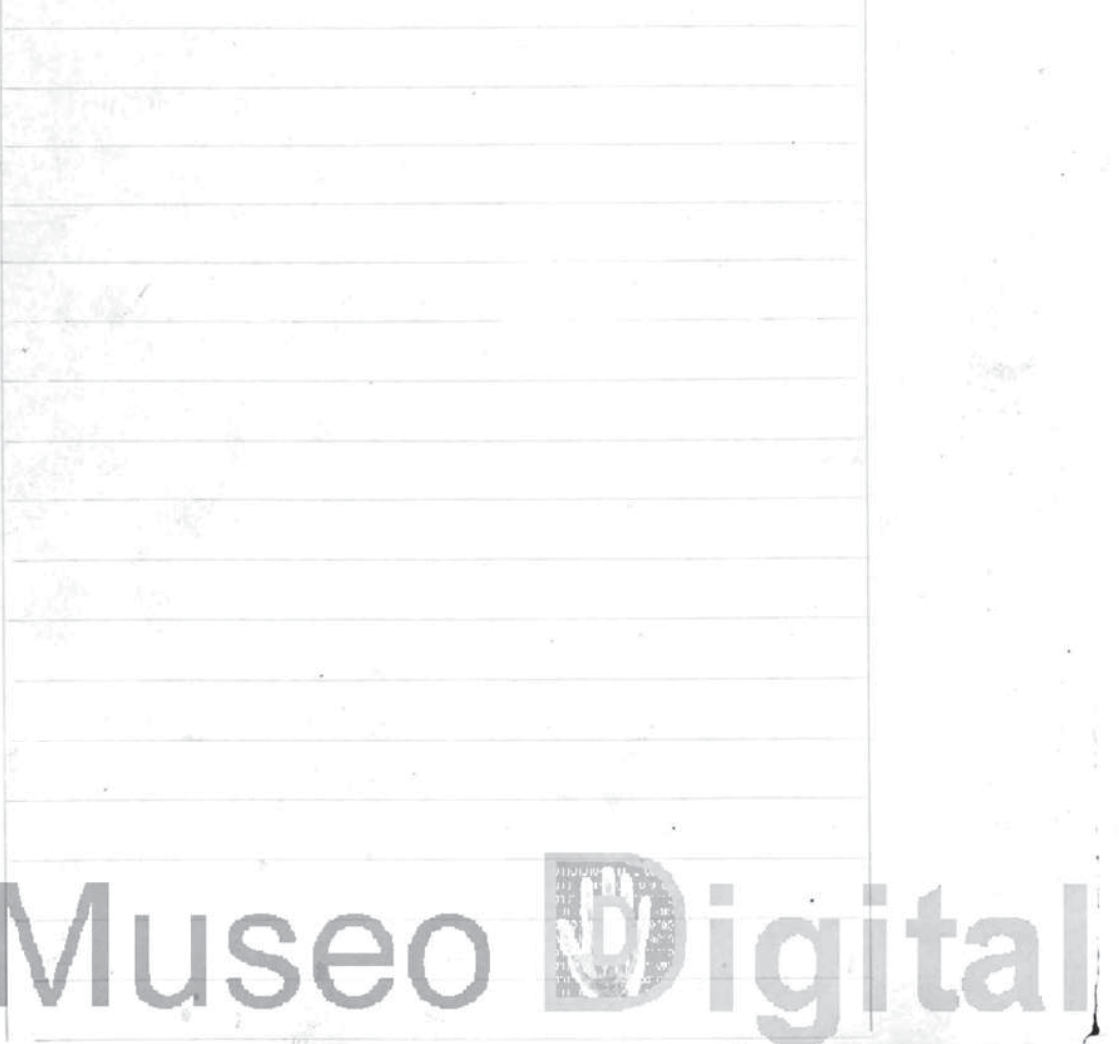

FACULTAD DE MEDICINA | UNIVERSIDAD DE CHILG 


\section{MEMORIA DE LA JUNTA CENTRAL DE VACUNA CORRESPONDIENTE A $1888^{21}$}

En 1883 se había creado la Junta Central de Vacuna, institución a cargo de organizar y propagar la vacunación en Chile, pero solo en 1887 el presidente José Manuel Balmaceda (1840-1891) promulgó la Ley de Vacunación Obligatoria de Viruela en el contexto de una epidemia de cólera que afectaba a la nación. Un año después de ese hito de la historia de la salud pública, la Junta Central de Vacuna publicó este documento en el que se daba cuenta de su organización y forma de trabajo.

De acuerdo con sus estadísticas, la aplicación de la vacuna de viruela mostraba resultados positivos y auspiciosos, pues, en una década, los datos de mortalidad por esa enfermedad habían decrecido en más de un 85 por ciento. Destacaron el rol cumplido por el Registro Civil para la construcción de estadísticas confiables y reconocieron que aún existían obstáculos para alcanzar a una parte de la población que seguía vulnerable ante la enfermedad.

Se trata de un documento que nos presenta el desarrollo de una concepción de la medicina en la cual el foco está puesto en la población y no en los individuos. Gracias a ella se realizaron acciones de carácter colectivo, ya no por medio de la caridad, sino que a través de una institucionalidad que tenía intenciones preventivas. Es una muestra de los cambios de mirada acerca de las enfermedades durante el siglo XIX.

21. Junta Central de Vacuna. Memoria de la Junta Central de Vacuna correspondiente a 1888, Santiago, Imprenta Nacional, 1889. Biblioteca Nacional de Chile. Disponible en: http://www. memoriachilena.gob.cl/602/w3-article-349027.html 


\section{E M O R I A}

\section{DBL \\ PRESIDENTE DE LA JUNTA DE.VACUNA}

Santiago, 4 de .Marzo de 1889.

SeÑ́or Ministro:

El servicio de vacuna tiene hoy la organización que le dió el Reglamento General del ramo dictado por supremo decreto de 19 de Marzo de 1883. Sea que la falta de una ley que organice este servicio haga que no todos conozcan su oŕganización, ó que no hayan fijado la atención para notar los benéficos resultados que ha producido, es lo cierto que, aún en el seno mismo del Congreso, se ha notado que no es conocida la forma en que se atiende este importante ramo de la salubridad pública.

Esta circunstancia y el interés general que todos tienen por este servicio, y para que su conocimiento preste la ventaja de ser estimado en su verdadero valor y estudiado para que se introduzcan acertadamente las mejoras que se estimen útiles, se ha creído conveniente dar una idea general, aunque suscinta, de la manera como está organizado el servicio de vacuna en Chile, buscando en la publicidad de esta memoria, que es costumbre insertar en 
la del Ministerio de US., el conocimiento autorizado de las ventajas de su organización actual.

El servicio de vacuna depende directamente del Ministerio del Interior, y su atención está confiada, en la dirección general, á la Junta Central de Santiago, de la que dependen las juntas particulares establecidas en los departamentos de la República.

La Junta Central, además de la dirección general del servicio, tiene la especial del departamento de Santiago, y está regida por un presidente y ocho vocales que desempeñan su cometido sin remuneración alguna.

Tiene, además, para la atención profesional del servicio, dos médicos, uno encargado del vacunatorio, y el otro de la inspección del éxito que se obtenga en las vacunaciones y del constante examen de la bondad del virus que se inocula.

En la parte administrativa tiene una secretaría con la dotación de empleados necesaria para el examen de los trabajos de los vacunadores, de las cuentas que rinden los médicos, d̂̀ la formación de la estadística general de vacuna y despacho de las órdenes é instrucciones que es necesario enviar á las juntas departamentales de toda la República.

Mantiene acopio suficiente de virus conservado de brazo á brazo, cuyo cultivo depende de ella exclusivamente; y recibe y propaga el fluído animal que, desde el mes de Septiembre de 1888, le proporciona la Sociedad Nacional de Agricultura, á quien el Supremo Gobierno confió la dirección y cultivo del vacunatorio animal que posee hoy el país, y que no trepidamos en colocar á la altura del más célebre vacunatorio de Europa, el de Nancy, en Suiza. El inteligente veterinario señor Besnard nada tiene que envidiar á las más reputadas celebridades del viejo mundo, y 
el resultado obtenido, como se demostrará más adelante, ha sido espléndido y con garantías tales que su establecimiento será una de las fechas más interesantes de su historia.

Las juntas departamentales son regidas por los intendentes y gobernadores, quienes las presiden, y se forman con dos municipales elegidos por la corporación, con un vecino nombrado por S. E. el Presidente de la República, y con un médico que reune á este carácter el de secretario y tesorero de la misma junta.

Tanto la Central de Santiago como las departamentales tienen el número de vacunadores necesario para la atención del servicio.

Los vacunadores son preparadoś en su aprendizage por el médico de sala de Santiago, adquieren la práctica en el vacunatorio y rinden su examen ante un miembro de la Facultad de Medicina, el médico de sala é inspector de vacuna, el presidente y secretario de la Junta Central. Rendida la prueba teórica y práctica, son nombrados vacunadores únicamente los que han merecido aprobación en una y otra.

Los vacunatorios, ó sea oficinas de vacuna, establecidos en cada departamento de la República, tienen por objeto vacunar en ellos á las personas que lo solicitan, y se anuncian en carteles fijados en lugares públicos de cada departamento los días y horas en que funcionan; y las personas que ocurren á vacunarse en ellos dejan anotado en las listas su domicilio para que, sin molestia alguna del vacunado, pueda comprobarse el éxito de la operación.

Los vacunatorios permanecen abiertos el tiempo necesario para atender los servicios que en ellos se solicitan, en Santiago y Valparaíso diariamente, y en las demás ciudades de la República día por medio, dos veces, ó una por semana, según sea la población y la determinación que haga cada junta departamental; pero el grueso de las vacu- 
naciones que se practican son todas á domicilio, como lo dispone el artículo 32 del reglamento.

Apenas habrá un punto en que la Junta Central haya consagrado mayor atención que hacer practicar las vacunaciones á domicilio. Conocemos el carácter indolente de nuestro pueblo y las resistencias que muchos tienen para recibir la vacuna. Las víctimas de la viruela que caen en los lazaretos son de personas no vacunadas; é interrogadas muchas de ellas por qué no lo han 'hecho, dan uniformemente por respuesta: «por dejación》.

Las importantes instrucciones dictadas en 1884 y 85, y repetidas comunicaciones reclamando su cumplimiento, muestran que las vacunaciones siempre se han practicado á domicilio, no sólo en las poblaciones urbanas sino también en la parte rural de cada departamento. En áquellos en que ocurre mayor número de personas á los vacunatorios, siempre se ha aumentado el número de vacunadores, para que nunca falte quien diariamente recorra la ciudad de casa en casa; y los mismos que atienden los vacunatorios deben practicar vacunaciones en la forma indicada en la mañana y tarde de cada día.

Otra prùeba de que el sistema indicado es el que se sigue, es la certificación que debe cerrar el trabajo de cada día del vacunador, firmada por los vecinos que presencian la vacunación, y certificada la autenticidad de esta firma , por los jueces de subdelegación ó distrito de cada lugar.

Comprende bien US. la necesidad de nuestra exposición y la extrañeza que nos ha causado cuando se ha pedido que las vacunaciones se hagan á domicilio, siendo ésta la forma establecida desde el comienzo del servicio; $y$ la instrucción dada á los vacunadores y reclamada por esta Junta, como consta de las anotaciones que figuran, entre otras, aún en el respaldo de las listas.

Este es el único medio también para vencer-las dificul tades anotadas anteriormente para la propagación de la vacuna. 
Dada una idea general de la organización del servicio, corresponde manifestar ahora el fruto alcanzado en 1888.

Nuestra primera palabra al dar cuenta en el presente año de la marcha del servicio es de grata satisfacción, presentando al Supremo Gobierno en su desarrollo y adelantamiento siempre creciente y que augura felices resulta. dos en el porvenir.

Cuando en el año de 1887 echábamos una mirada general sobre la influencia de la vacuna en el país, no pudimos sino felicitarnos por sus resultados. Á la par que el cólera diezmaba la población, la vacuna desterraba la viruela, y la vacunación extraordinaria hecha con seriedad fué de indiscutible provecho.

Las víctimas de la viruela en 1887 fueron 1,147 en toda la República, y de éstas 22 correspondieron á Santiago. Toda persona desapasionada pudo ver entonces que el implacable cnemigo dejaba sus reales, abandonando el campo que le era propicio, porque debe reconocerse que la viruela es endémica en el país.

El estudio estadístico que aparece en la Memoria de 1887, hecho ese año, fué altamente consolador, y todo Chile dió por bien emp̀leados los caudales invertidos en la vacuna, á cuya influencia, sin duda alguna, se debió el resultado obtenido.

Hoy nuevamente hacemos un estudio general del servicio, si cabe con mayor satisfacción, pues en 1888 la viruela no ha hecho sino 341 víctimas en la República, y de estas sólo 2 en la provincia de Santiago. La disminución que se advierte y la estadística que hoy presentamos como dato exacto y comprobado en el cuadro número 1 reviste la seriedad de un documento público, pues se ha tomado de las oficinas del Registro Civil, dejando en nuestro archivo las listas nominales de la República, que pue- 
den ser examinadas por quien desee comprobar la verdad de nuestro aserto.

Jamás en Chile se ha presentado un número más reducido de defunciones por viruela.

Para comprobar este hecho bastará repetir aquí el dato que hacíamos constar en la Memoria dèl año anterior.

DEFUNCIONES POR VIRUELA EN TODA LA REPÚBLICA

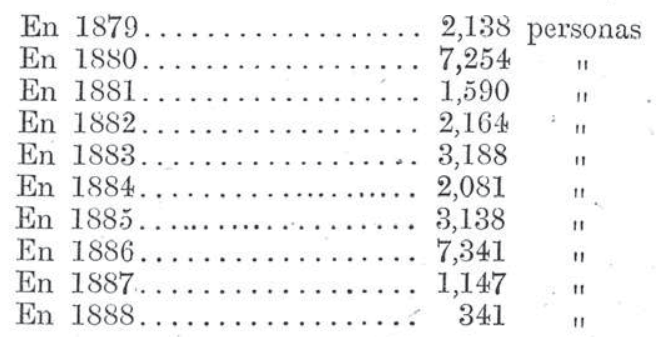

DEFUNCIONES POZ VIRUELA EN SANTIAGO

En $1879 \ldots \ldots \ldots \ldots \ldots \ldots . \ldots 82$ personas

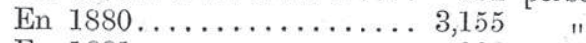

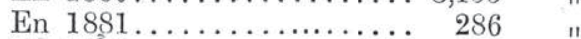

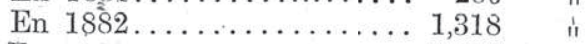

En $1883 \ldots \ldots \ldots \ldots \ldots \ldots$ 1,533 "

En $1884 \ldots \ldots \ldots \ldots \ldots \ldots \ldots \ldots \ldots \ldots \ldots$ 1,

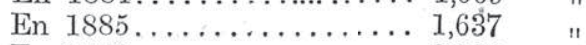

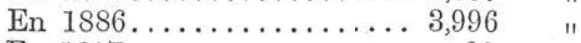

En $18,7 \ldots \ldots \ldots \ldots \ldots \ldots .22 \quad$ "

En $1888 \ldots \ldots \ldots \ldots \ldots \ldots$ 2 -

Este dato es más estimable aún si se atiende á que los datos estadísticos que presentamos desde el establecimiento del Registro Civil, esto es, desde el año 1884, son más generales que los que antes se recogían únicamente de las estadísticas de los hospitales y lazaretos.

Al Registro ocurre hoy todo Chile, y por eso el dato es completo.

Pero hemos dicho que damos este dato con especial sa- 
tisfacción, y ésta nace de dos causas: $1 .^{\text {a }}$, que la disminución del número de defunciones por viruela, que ha hecho menos víctimas que ninguna otra enfermedad en el país, persuade de la influencia de la vacuna; y $2 .{ }^{a}$ porque, sin negar la influencia que aún tiene la vacunación de 1887, la ventaja que se advierte en el presente año se ha obtenido únicamente con el servicio ordinario establecido, y por consiguiente, con gasto bien limitado.

\section{III}

Es indudable que á pesar de las ventajas con que día á día se presenta la vacuna, disminuyendo en parte las resistencias, se interpone en su camino, especialmente, la indolencia del bajo pueblo, en el cual la viruela hace mayor número de víctimas. Agregada á esta causa la falta de aseo y de higiene en sus hábitos, hace indispensable preocuparse de un modo especial de la vacunación del pueblo, que forma la mayoría de la nación.

Desde años anteriores esta Junta se ha ocupado de la atención preferente de esta parte del servicio.

Con la vacunación extraordinaria se obtuvo, entre otros bienes, el de llevar la persuación por medio de individuos particulares que no aparecían ante los pobres como agentes oficiales, y podrían ver que el único móvil que los llevaba era ofrecerles un inestimable bien.

Creemos que la parte no vacunada en Chile la forman los adultos de la clase pobre, especialmente los hombres, que son ordinariamente las víctimas de la viruela. Esto nace, á nuestro juicio, en parte, de que no han sido vacunados en su primera edad, única época en que por falta de fuerzas no emplean su tiempo en el trabajo necesario para su sostén: de aquí la importancia del servicio de los recién nacidos, decretado por el Supremo Gobierno y pedido por esta Junta; medida que ha ganado inmensamente con el decreto dictado por el Ministerio de Justicia, 
obligando á los oficiales delR egistro Civil á enviar el día. primero de cada mes al Presidente de la Junta Departamental de Vacuna respectiva, una lista de los nacimientos inscritos en su registro durante el mes anterior, indicando en ella el domicilio de cada uno de los nacidos.

Esta medida facilitará mucho el servicio, no pudiendo aún estimarse sus resultados de una manera exacta, pues se ha establecido en Octubre, según circular del Inspector del Registro Civil; y la vacunación, para obrar en conformidad con las indicaciones del cuerpo médico de Santiago y práctica constante, debe venir tres meses después.

Con todo, en las copias tomadas anteriormente de los libros del Registro Civil y en las pasadas por estos funcionarios, en cumplimiento del decreto antes citado, se advierte gran vaguedad en la fijación del domicilio, no sólo de la parte rural sino también de la urbana. En Chillán, por ejemplo, no están numeradas las casas y las calles tienen una extensión hasta de veinte cuadras; y para encontrar el vacunador al recién nacido necesita recorrerla toda por ambas aceras, còn pérdida de considerable tiempo y penosa fatiga del vacunífero que le acompaña.

En la parte rural ordinariamente se indica como domicilio el número ó nombre de la subdelegación, y siendo éstas muy extensas, muchas de ellas de veinte ó más leguas, no es casi posible encontrar al recién nacido si no se agrega en la fijación del domicilio el nombre del lugar, hacienda ó establecimiento. De esta manera, aunque sean extensos los lugares, los dueños ó administradores pueden dar noticia del lugar preciso del domicilio de sus inquilinos 6 dependientes.

Además, podría introducirse una mejora para la atención de este servicio. El nombre que los padres dan á sus hijos es ordinariamente desconocido, hasta que con los años rolan en la sociedad que forman parte. En un lugar, por ejemplo, todos los comarcanos conocerán á Pedro 
González, antiguo domiciliario de él, y nadie ó muy pocos á Ángel González, su hijo, recién nacido, á quien sus cortos años aún no le permiten tomar parte en las faenas, punto de reunión y de relaciones en los campos. Convendría entonces agregar á las nóminas de los recién nacidos el nombre del padre ó madre de cada uno de ellos.

Esta Junta Central cree que, por grande que sea el trabajo y numerosos los inconvenientes que se presenten para la atención de los recién nacidos, debe procurarse vencerlos tomando en cuenta las ventajas que está llamada á producir.

Las medidas indicadas no introducen variación alguna en el registro y pueden con celo y esmero llenarse, pues se reducen á una determinación clara del domicilio, que el ocurrente siempre conoce, y á agregar en las nóminas un nombre que aparece en el registro.

\section{IV}

Como se ha manifestado antes, las vacunaciones en 1888 han sido únicamente producidas por el servicio ordinario; no es exträño entonces que su número seà menor al del año anterior; pero, como todos los datos de este género suministrados por la Junta Central de Vacuna, desde tiempo atrás, merecen fe; porque, como en los años anteriores, se ha comprobado su veracidad dándose por bien empleadas las cantidades gastadas con este objeto; además de las comprobaciones hechas por el inspector del ramo y otros empleados del servicio.

Cuando se ha sorprendido alguna falsificación se ha solicitado en el acto del Supremo Gobierno la destitución del vacunador y pasado los antecedentes á los juzgados del crimen respectivos, para su castigo.

Tales medidas, como comprende bien US., son por demás ejemplares y evitan que tan doloroso suceso se repita.

Además, difícilmente puede ocurrir una falsifica ción sin 
que sea descubierta, no solo por la vigilancia de los médicos del ramo, de quienes dependen inmediatamente los vacunadores, sino por la fiscalización que se establece entre los trabajos de éstos y las cuentas de aquéllos; siendo, además, necesario convenir que tradicionalmente en esta Junta Central se ha tenido diligente empeño en procurar que los vacunadores sean dignos y honrados, no admitiéndose ninguno en calidad de aspirante sin que lo acrediten buenas recomendaciones de personas honorables, como lo dispone el reglamento.

Excusado será advertir que en los casos raros de falsificaciones en las listas, esos datos se han eliminado del resumen general que se acompaña á esta memoria bajo el número 2.

\section{V}

Bajo el número 3 se acompaña un cuadro que contiene las vacunaciones hechas con virus animal; y notará US. su escaso número.

El virus animal nos ha sido suministrado por la Sociedad Nacional de Agricultura por primera vez el 28 de Septiembre de 1888, y después periódicamente en la cantidad y envase pedidos por esta Junta.

Inmediatamente del primer envío se repartió á las juntas departamentales de la República para comprobar su bondad y producción, pudiendo manifestar á US. que sus resultados fueron satisfactorios.

Con el segundo envío se ordenó un estudio comparativo del virus animal con el de brazo á brazo que cultiva esta Junta; uno y otro conservados para que el estudio se hiciera bajo idénticas condiciones.

El resultado de este estudio ha probado la bondad de uno y otro virus, $y$, en consecuencia, la conveniencia de mantenerlos para poder satisfacer de este modo los deseos de todos. 
En la tercera remesa se hizo un nuevo estudio en tres transmisiones comparadas de virus animal y humanizado, para notar el vigor de uno y otro y la mayor ó menor facilidad para su degeneración.

Este estudio, como los anteriores, produjo brillantes resultados, teniendo en nuestro archivo las observaciones hechas por la mayor parte de los médicos de vacuna de la República.

Podemos, pues, asegurar que la calidad y vigor del virus animal cultivado en el vacunatorio establecido en la Quinta Normal de Agricultura, es espléndido, y que, mediante su cultivo, puede hoy satisfacerse en Chile, con provecho, las necesidades aún del más exigente.

Ventaja tan inestimable, que importa un progreso notable en el país, nos ha obligado í enviar circulares á las naciones americanas, ofreciendo el indicado virus; $y$, desde luego, puedo anunciar á US. que se ha hecho una remesa al Golierno de Bolivia.

- Estas ventajas destruirán también las resistencias á la vacuna de aquellos que no estimaban el virus de brazo á brazo suficientemente garantido.

En el campo de la opinión cada uno tiene sus ideas, é importa gran conveniencia para un servicio que lo debe todo á la confianza con que se le recibe, poder satisfacer aún al más exigente.

El estudio comparado de que damos cuenta, de los efectos del virus de brazo á brazo y del animal, muestra á la vez que es indiscutible la bondad de uno y otro.

Renovado el virus existente en el país con el animal proporcionado por la Sociedad Nacional de Agricultura, se mantiene hoy en cada Junta Departamental tanto el virus de brazo á brazo como acopio suficiente del animal para que se emplee uno y otro á voluntarl del vacunado.

En el cuadro núm. 4 aparece el número de tubos capilares con virus de brazo á brazo repartidos durante el año, y en el núm. 5 el de placas y pomos de virus animal, que 
es la forma más conveniente para conservarlo y en la que hay menos desperdicio.

\section{VI}

Se ha manifestado antes que en la atención del servicio en el año de que damos cuenta se han invertido las sumas que el presupuesto señala para el servicio ordinario.

Corresponde ahora manifestar el detalle de esa inversión, el que encontrará US. en los cuadros núms. 6 y 7.

En el primero, aparece el balance formado de las juntas departamentales, según las cuentas rendidas á la Junta Central; y en el segundo, el balance de los fondos invertidos por esta Junta Central.

Pronto podrá presentarse al tribunal correspondiente la cuenta general de vacuna del año 1887, que está completamente terminada, y sólo se aguarda para rendirla el finiquito de la cuenta anterior.

Se deja sentir la necesidad de aclarar la disposición que contiene el núm. $60^{\circ}$ del artículo 40 del Reglamento sobre reñdición de cuentas de las juntas departamentales.

Es indudable que la fiscalización de la Junta Central es indispensable en este delicado ramo del servicio.

Únicamente por este medio se pueden evitar gastos inútiles y escrupulosidad en los necesarios.

Es conveniente entonces dejar establecido que las juntas departamentales únicamente pueden invertir las sumas necesarias, con arreglo á las instrucciones de esta Junta, en pago de vacuníferos y útiles de escritorio; y que todos los demás gastos deben previamente ser autorizados por la Junta Central para calificar su utilidad, y que no se comprometan las entradas futuras de cada junta, pudiendo llegar el caso, sin esta medida, que un departamento, por adquisición de muebles y útiles para una oficina, llegue á carecer de los fondos necesarios para la atención del servicio. 
Esta medida, agregada á la obligación de las departamentales de rendir euenta trimestralmente á la Central, como se ha practicado hasta hoy, hará mantener la economía que se advierte en la inversión de los fondos de vacuna.

Además, siendo las juntas departamentales quienes reciben y administran los fondos, es necesario que cada una de ellas, después de ser aprobada por la Central la inversión legal de los que administra, rinda directamente cuenta documentada al Tribunal Superior de Cuentas para cancelar su responsabilidad.

No divisamos objeto alguno en que la Junta Central forme y rinda la cuenta particular de cada departamental; desempeñando, en términos rigorosos, el de papel de amanuense de sus subordinados, sin que tenga la responsabilidad de los fondos de esas juntas desde que ni los recibe ni los administra.

Esta resolución se armonizaría perfectamente con las reglas de contabilidad establecidas en la República que por la ley de 20 de Enero de 1883 obliga á las tesorerías á rendir cuenta legal de entradas y salidas á la Dirección de Contabilidad Jeneral y la documentada á la Contaduría Mayor, hoy Tribunal Superior de Cuentas. Garantida con la primera la inversión legal de los fondos que consulta el presupuesto, se comprueba con documentación de la segunda la efectividad de los gastos, y el fallo del Tribunal cancela ó afecta la responsabilidad del administrador de dichos fondos.

El temperamento que se indica respecto de las juntas departamentales de vacuna, establecería en este ramo del servicio á la Junta Central con el rol de la contabilidad general que es natural le corresponda por la dirección superior del servicio que le está confiado, y al Tribunal Superior de Cuentas el conocimiento y resolución que le corresponde en todas las de la República.

Esta disposición, por otra parte, eliminaría de la Junta 
Central una parte del trabajo que le dejaría disponible mayor tiempo en las multiplicadas atenciones que le corresponden.

\section{VII}

Según el artículo 29 del Reglamento, los vacunadores, además de sus sueldos, gozan de viáticos para atender con ellos á los gastos de la visita rural, es decir, transporte, alimentación y alojamiento del vacunador y vacunífero. El Reglamento acuerda también viáticos á los inspectores del ramo. El cuadro núm. 8 manifiesta los viáticos pagados á los vacunadores é inspectores del ramo durante el año 1888.

\section{VIII}

Es en gran manera interesante la visita que se practica en las juntas departamentales; por este medio se extirpan mil malas prácticas que de otro modo no llegarían á conocímiento de la Junta Central. Además, cuando se presentan dificultades sobre cuentas ó alguna cuestión entre los empleados del servicio, tenemos con el inspector un órgano desapasionado que informe al respecto, y las resoluciones que se libran por la Junta tienen una garantía más de acierto.

En el año que expira se ha practicado una visita general de inspección en toda la República, y por este medio tenemos conocimiento de que en general el servicio tiene una marcha regular y correcta, pudiendo presentar á US. el personal de sus empleados en el cuadro núm. 9.

Por la visita de inspección practicada se ha notado que las oficinas de vacuna prestan escaso servicio, ya porque muchas estín mal situadas, otras porque sus edificios son poco apropiados, y en casi todas porque, en razón de su ubicación, no pueden ser vigiladas convenientemente por 
los presidentes de las juntas departamentales, que son los Intendentes y Gobernadores.

El servicio de vacuna es de los servicios públicos más interesantes. Combatir la viruela, endémica en el país, impone una necesidad que obliga á los encargados de la vacuna á calificar de necesaria la atención de este ramo del servicio público.

No hay una sola voz en la República que manifieste lo contrario, y son por demás justificados los desvelos del Supremo Gobierno para la conveniente atención, persuadido de su importancia.

Después de estos antecedentes, aparece como urgente necesidad dotar al servicio de vacuna de oficinas, en los edificios públicos que se construyen, uniendo á los demás servicios el que á nuestro juicio tiene mayor importancia.

Situadas las oficinas en las casas consistoriales, que siempre tienen una ubicación central, ganarían en prestigio y buen orden, y, sobre todo, se establecería una vigilancia tan fácil como conveniente para producir los benéficos resultados que todos anhelamos.

De esta manera se economizaría también, por lo ménos, una tercera parte de la asignación fiscal destinada á la atención del servicio, y todos verían con gusto llenos los vacunatorios, hoy desiertos, porque en muchas partes no es posible llegar á una oficina que no tiene á veces la decencia necesaria.

Un servicio como el de vacuna, que encuentra resistencias, debe presentarse fácil y cómodo para no aumentar el retraimiento.

Juzgamos, pues, esta medida indispensable para el mejoramiento del servicio que se nos ha confiado.

\section{IX}

Para preparar á los vacunadores que atienden el servivicio en los departamentos, se ha formado bajo la direc- 
jión del médico de sala varios cursos con resultados satisfactorios. Asimismo, como en el año anterior, se ha hecho un curso especial para los alumnos del superior de la Escuela Normal de Preceptores, cuya importancia no necesita manifestarse.

Todas las plazas de vacunadores se han llenado, y nos es grato consignar en esta memoria que en general su desempeño ha sido correcto, debido, sin duda, á las garantías que el Reglamento establece para que estos puestos se den á empleados dignos y honrados.

Los premios que el artículo 47 del Reglamento asigna á los vacunadores que han ejecutado un mayor número de vacunaciones, con relación á la población no vacunada, que hubieren alcanzado mayor eficacia en sus operaciones, y que hubieren probado más celo en el cumplimiento de sus deberes, se han discernido por el año de 1887 á los siguientes vacunadores:

\section{PRIMEROS PREMIOS}

A don Máximo A. Valdovinos, vacunador de San Felipe, y á don Juan Francisco Leiva, de Casablanca.

\section{SEGUNDOS PREMIOS}

A don Ismael Arancibia Lagos, vacunador de Loncomilla; á don Federico 2. ${ }^{\circ}$ Aguirre, de Lontué; y á don José Bernardino Álvarez, de Viçtoria.

Además se acordó dar una mención honrosa al vacunador de Vallenar, don Domingo A. Bravo.

Termino esta memoria manifestando á US. que esta Junta reconoce las facilidades dadas por ese Ministerio á la Junta Central para la conveniente atención del servicio. 


$$
-19-
$$

Debido á esta ventaja y al cumplimiento exacto del Reglamento, tenemos la satisfacción de manifestar á US. que nuestra tarea ha sido fácil y próspero su resultado, abrigando la esperanza de que este servicio tenga aún un porvenir más lisonjero en lo futuro.

Dios guarde á US.

\section{Rodolfo Hurtado.}

$\mathrm{Al}$ señor Ministro del Interior. 


\section{LOS CHILENOS CAUTIVOS VENDIDOS POR DAZA: MÁS DETALLES DE LOS CAUTIVOS: LA INFLUENZA: UN PROMETIMIENTO ${ }^{22}$}

La histórica enfermedad conocida como influenza o "gripe española", con características de pandemia por su propagación mundial, ha azotado nuestro país en varias ocasiones. Tenemos noticias de brotes de gran impacto para los años 1737, 1880-1889, 1918 y 1933. Algunos autores consideran que el evento de 1918 podría ser la pandemia más importante del siglo XX.

El presente documento, de autoría desconocida, pertenece a la Lira Popular, y en él podemos observar cómo se vivió esta enfermedad entre los sectores populares. A lo largo de los versos se describen los dolorosos síntomas, la incertidumbre de no tener una cura, la rapidez del contagio entre todas las clases sociales y la cercanía de la muerte.

Se denomina como Lira Popular a un conjunto heterogéneo de pliegos sueltos de gran formato que circulaban en los principales centros urbanos de Chile a fines del siglo XIX e inicios del XX. En estos, los y las poetas populares plasmaban tensiones sociales, costumbres, sentimientos, hábitos y conductas populares del periodo. Estas características hacen que la pieza que presentamos posea gran valor, pues permite conocer cómo se percibieron las enfermedades entre los ciudadanos comunes, particularmente, las pandemias.

22. Los chilenos cautivos vendidos por Daza: más detalles de los cautivos: la influenza: un prometimiento, ca. 1866-1930. Colección Lira Popular, Archivo Central Andrés Bello. Disponible en: https:// bibliotecadigital.uchile.cl/. 


\section{LOS CHILENOS CAUTIVOS VENDIDOS P0R DAZA}

\section{LOS CIILLEIOS CAUTIVOS IENDIDOS POR DAZA}

Daza fús aquel anatema Que a los Chilenos vendio, Oue no quede sin castig. 1 euico que los compró.

Fueron de aquel batallon Segrundo de livea hallaron I en Tarapacá pelearon I alcanzaron opinion: Ramirez con intencion Su valor sirvió de poema; Habian oido el problema I Arica llegaron presos, El autor de estos execsos Daza fué aquil anatema.

Para el Beni i sus rejiones Llevaron a los valientes, Como esclavos obedientes I cargados de prisiones, Alli oian mil valdones A Ohile por que venció, 1. el cobarde, recibió De todos el precio igual, Eso lo hizo el Jeneral

Que a los Chilenos vendió. Los hacian trabajar Como que estaban vendidos, Sin -er de nawie at ndidos I esto era sin descanzar: Todo era un tierno llorar I el trato como enemigo, I burlados como digo Salieudo de tolas dindss, Ese boliviano i judas Que no quede sin castigo.

El dia de carnaval

Luis Araya i Valenzuela, Embriagado el centinela Se fugaron fué casual, Serca de un año campal Fué sn marcha i le tocó, Que un reptil lo enrenenó Desesperado se advierte, Responderá por su muert El cuico que los compró.

Al fin nuestro Presidente Ya sabe que los cautivos, Son sus hijos activos

I legados del valiente: Han puesto su pecho al frente Por darle a la Patria houor Al escuchar el clamor Como de esclavo vendido Diez años hau padecido Por Daza el inquicidor.

MAS DETALLES DE LOS CAUTIVOS El elamor de los eantivos A Santiago no ha llegado Telegratió al consulado.

Penoso es el argumento De aquellos veintiun guerreros; Com i fieron prisioneros I vendidos al momenta; Tienen de padecimiento Diez aũos cunsecutivos Qnedus difzinueve vivos I entr flos una mujer: Una cars dio a saber El clazor de los cautivos.

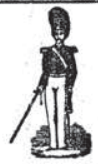

De los pies a la cintura Han estado encadenados Por los indios custodiados Durmiendo en la tierra dura: En tan penosa clausura I en $\tan$ miserable estado, Suspirando acougojado Dijo, uno entre su delirio, Este penoso susyiro

A Santiago no a llegado.

Una vez un misionero A uno de elles confesó Dijo el pobre, padre yo Ya me conozco que muero Bn verdad la muerte esper Que dé fin a mi existencia, Agusauado en presencia I de hambre vol a morir, Así Jos manitó pedir Lo que supo su Exelencia.

Juan Valenzıela llegó A la $\mathrm{Pa}$ cual peregrino Con un año de camiuo I su escena la cont $\delta$; Su narracion esplicó

Con frecnencia al encargado, Siendo de ello cerciorado I con orden evidente; Así el Señor Presidente Telegrafió al consulado.

Al fin Daza el jeneral Tirano entre los tiranos Vendiste nuestros hermanos De nuestra Patria natál; Esa mancha esa señal Te quitó honra i razon, Por ese negro borron

Has salpicado tu pecho,

I ese deraire le has hecho Al padre de mi nacion.

\section{LA INFLUENZA}

Quen puso nombre a la inflnenza Entermo decia un huaso,
Mas bien que le hubieran puesto El terrible garrotaso.

Los doctores no han podido Darle con la contra al mal; Por que esto es en jeneral Que a todos ha coinbatido: I en la costa es comprendido Que halla la jeote indefenza. DÐallá llegó el que mas piensa Al medicamento diario, Le preguntó al boticario Quien puso nombre a la influenza.

Tengo un dolor de cintura Se quejaba un dependiente. Creo que es el accidente

Que me viene una amargura; Ormo una descompostura De cuerpo tambien al paso. De la cabeza hasta un brazo Tengo un dolor como digo, Yo estoi lo mismo mi amigo Enfermo decia un huaso.
Una señora mayor

Padecía de este mal,

I un doctor del hospital

Diciendole con amor

Usted va a sanar con esto;

El facultatiyo presto

La anciana a decir se aplica,

Protector de la botica

Mas bien que le hubieran puesto.

Tres o cuatro en una casa

Suelen estarse quejando,

Clemoi sal deokin tomando

I el fiebre que los abrazã;

Cortadores de la plaza

Caen de a sais de un porrazo,

I un peoncito de los huaso

Al protomédico decia:

Señor mas bien le venía

Bl terrible garrotaso.

Señores estan muriendo

Pobre tambien como ricos

Grandes jovenes i chicos

Del mąl estan padeciendo;

I al parecer va cundiendo.

Se ignora si ha de durar

I si quieren aplacar

$\mathrm{Hu}$ repetido una voz

El encounendarse a Dios

$E^{\prime}$ 's lo mejor del pensar. UN PROMETIMIENTO

Si supfera que eras diosa Te malara bacer un templo. Dentro de mi pensumiento.

Mitolojico poder

Tuvo Euterpe diosa bella

quien le dsi mi querel

Amo vuestro pareer.

Como a Elena griega hermosa,

I si tu pensar repose

Como lo hacen ninfas tantas.

Fuera a ridirme a tus play
Si supiera que eras diosa.

A Minerva sabia pido

Que me obstrve mis ela

Aqui reras los ardores

Que mi pecho a consentido,

Palas en otro sentido

En amar puso un ejemplo,

Como a Vesta contemplo

I si fuera salomon.

Deidad que a Bolona i Dia

A imitado to hormosura;

I praeba que A mirarte a to ventana Dia i noche me asomara. Para que mi contestara Como Galatea el leal I al ser de estirpe tan rea Como diosa te adorara.

Raquel artigua matrona

I tu eres visaria dama: Mi deber gustoso esclama Que mereces la eorona; Como cińo la borgoña Aplandiendo su contento, De Andrómacs vuestren to Tu caracter sellaré Dentro de mi pensamiento.

Al fin como dualicana Os comparo tu belleza; De la triufanta palian Tu costancia amerisana Tienes de Menemoeina; Tu faz siempre me domina I de tu emblema señalan, Lo cierto es qne no te ig uala Ni Flora ni Proserpina. 


\section{ORGANIZACIÓN DE LOS SERVICIOS MUNICIPALES DE HIGIENE ${ }^{23}$}

El doctor Alejandro del Río Soto-Aguilar (1867-1939) estudió en el Instituto Nacional y en la Universidad de Chile, y se tituló de médico cirujano en 1889. Fue ayudante de Patología General y Anatomía Patológica en la Escuela de Medicina (1887-1888). Una vez titulado, realizó estudios de higiene pública en Europa, donde permaneció cuatro años. Estuvo en el Instituto de Higiene de Alemania y representó a Chile en los Congresos Científicos de Roma y Budapest. En 1897 fue nombrado profesor de Higiene en la Escuela Médica y, simultáneamente, director del Instituto de Higiene. Participó en el control de las epidemias de tifus y peste bubónica de 1903. Entre las instituciones que erigió se encuentran la Escuela de Enfermería, en el Hospital Arriarán (1902), la primera de su género en Sudamérica. Se le considera el fundador de la medicina social chilena, pues instituyó la Asistencia Pública de Santiago en 1911, la que dirigió por 18 años. También fue el creador de la carrera de médico sanitario, del Consejo de Protección a la Infancia y el Consejo Superior de Enfermería.

El texto que se presenta es un proyecto para organizar los servicios de higiene a nivel Municipal y en el cual se aboga por la promulgación del Código Sanitario de 1918. En él señala que un médico por su propio título no es un higienista, que para ello se requiere otros estudios que permitan saber cómo controlar y prevenir las enfermedades contagiosas y las epidemias. A él se debe la unificación de los Servicios Sanitarios del Estado y Municipalidades. Fue el primer Ministro de Higiene, Asistencia, Previsión Social y Trabajo (1924), cargo que solo ejerció por tres meses, debido al golpe de estado que efectuó Carlos Ibáñez al gobierno de Alessandri Palma. En 1925, retomó el cargo, pero como Director General de Sanidad.

A su muerte (5 febrero 1939), la Asistencia Pública, primer servicio de urgencia permanente en Chile, ubicada en un terreno de propiedad original de los jesuitas, en la calle San Francisco, esquina de Alonso Ovalle, fue honrada con su nombre.

23. Del Río, Alejandro. Organización de los servicios municipales de higiene, [Chile], s.f. Disponible en: https://bibliotecadigital.uchile.cl/discovery/delivery/56UDC_INST:56UDC_INST/12170 530860003936 


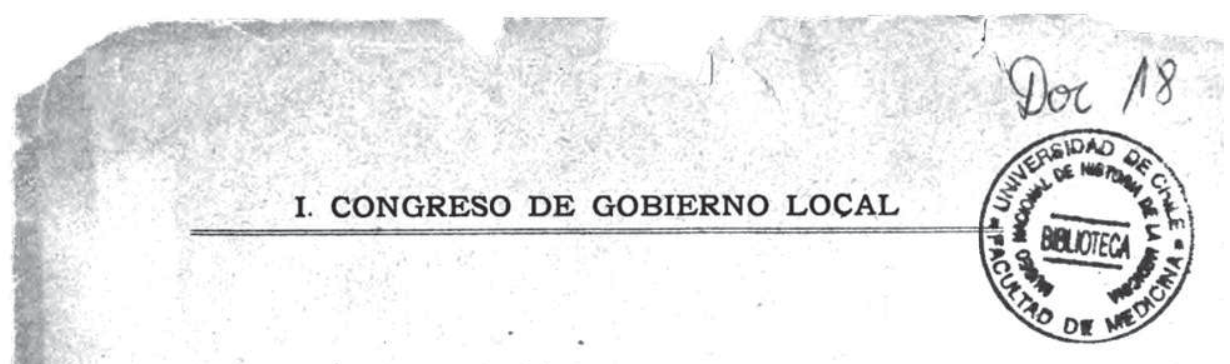

\title{
ORGANIZACION
}

DE LOS

\section{Servicios Municipales de Higiene}

\author{
por el Dr.
}

\author{
ALEJANDRO DEL RÍO \\ Ex-profesor de Higiene y Bacteriologia de la Escuela de Medicina, \\ Ex-director del Instituto de Higiene, \\ Miembro del Consejo Superior de Higiene y Administrador de la Asistencia Páblica de Santiago,
}

\section{SEÑORE:}

Los conocimientos definitivamente adquiridos en orden á la conservación de la salud y á la prevención de las enfermedades, particularmente de aquellas de carácter contagioso y epidémico, crea á las autoridades locales la obligación ineludible de buscar solución práctica, á la vez que efectiva y económica, á los problemas sanitarios.

La acción sanitaria es esencialmente previsora y requiere ser organizada en vista de un rendimiento positivo en hechos prácticos y ser todavía disciplinada por el ejercicio euotidiano de sus medios de acción. Es una ilusión que conduce á lamentables fracasos y al derroche inútil de dinero ereer que es posible improvisar en circunstancias dadas servicios y personal sanitario. Las ingentes sumas que consultan año á año el presupuesto nacional ó leyes es. peciales para combatir enfermedades epidémicas, si bien sirven para satisfacer necesidades de carácter humanitario, tienen escasa ó nula acción sobre el estado sanitario del país.

Deseo insistir particularmente en la afirmación de que es imposible improvisar un personal sanitario debidamente preparado.

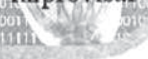




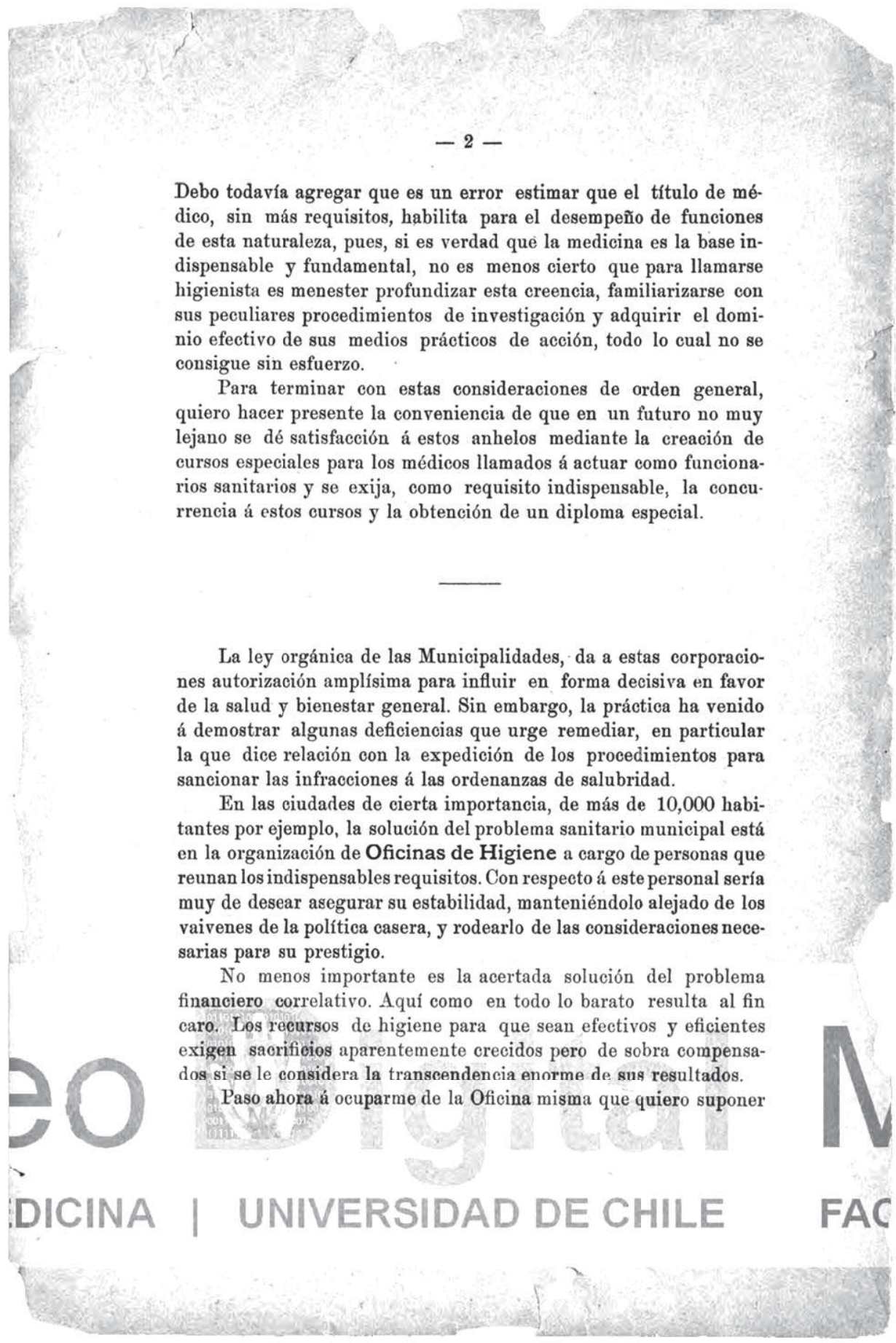




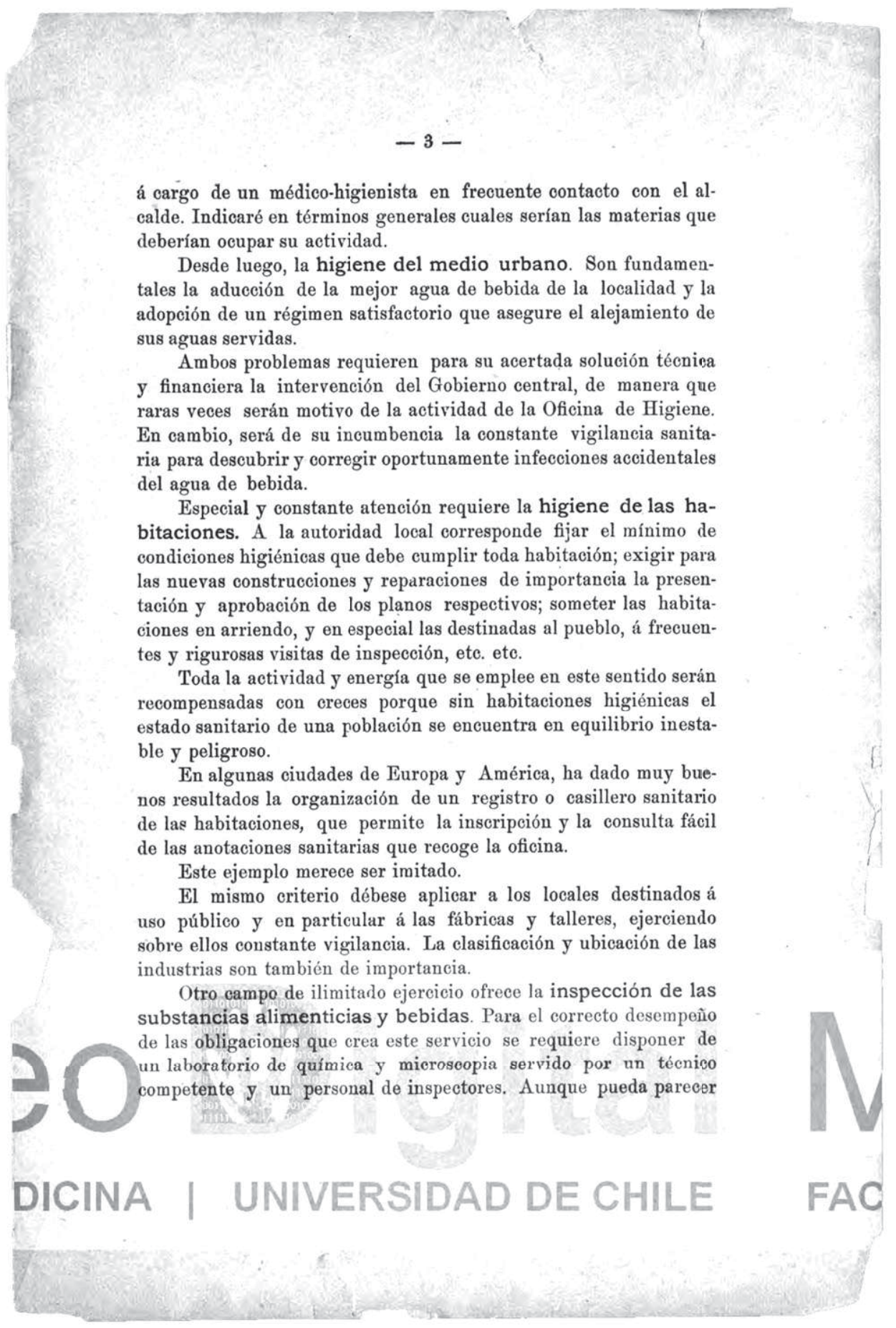




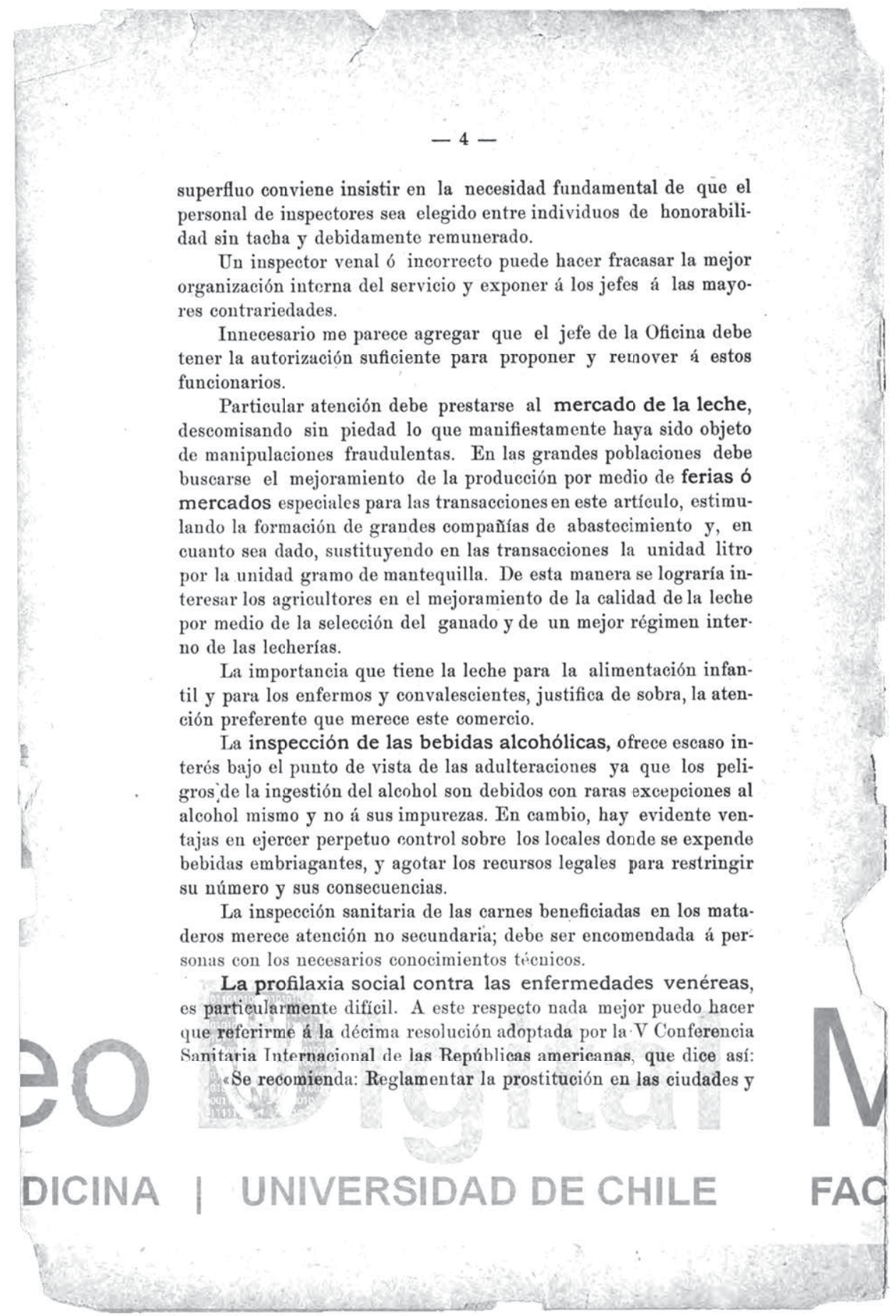




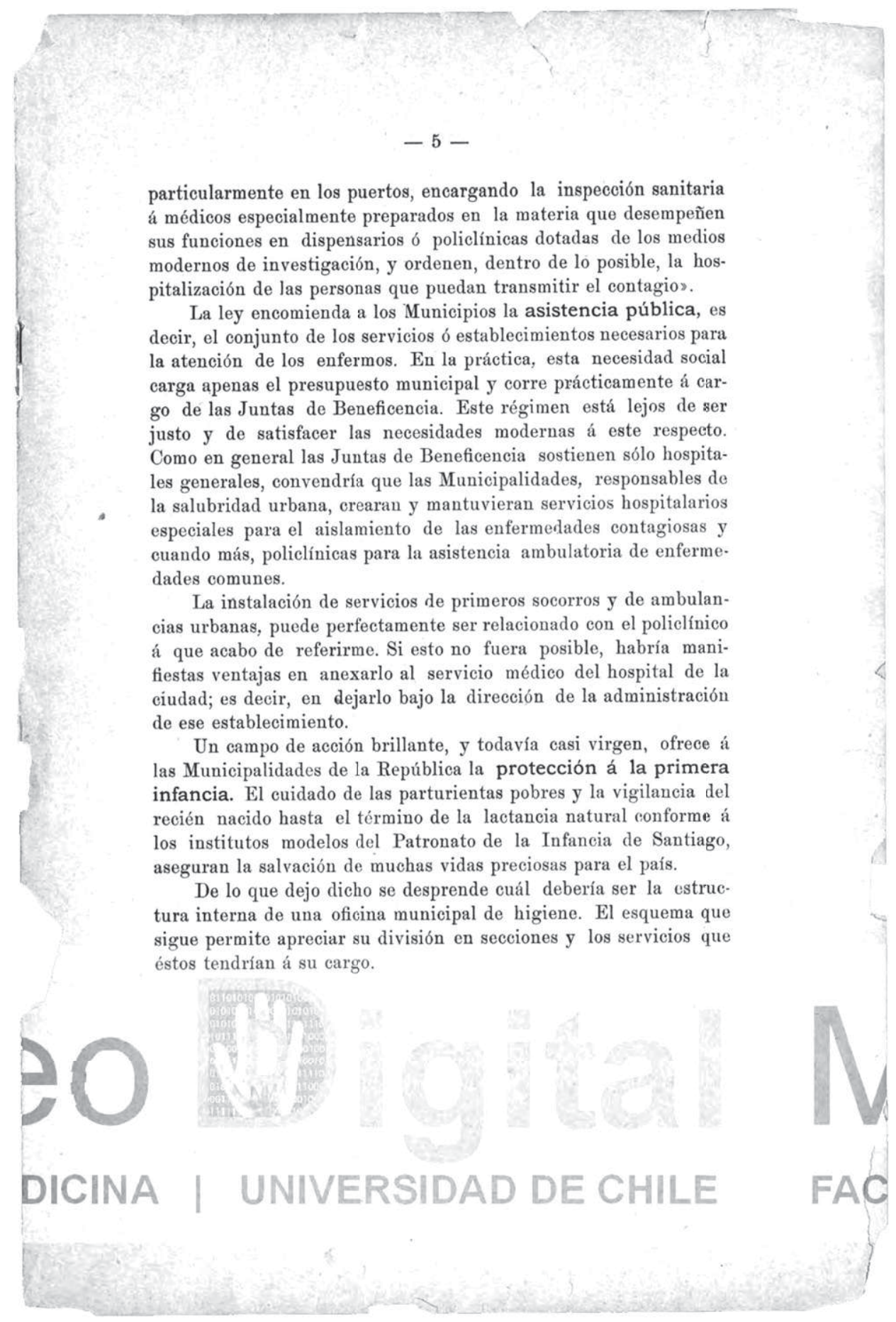




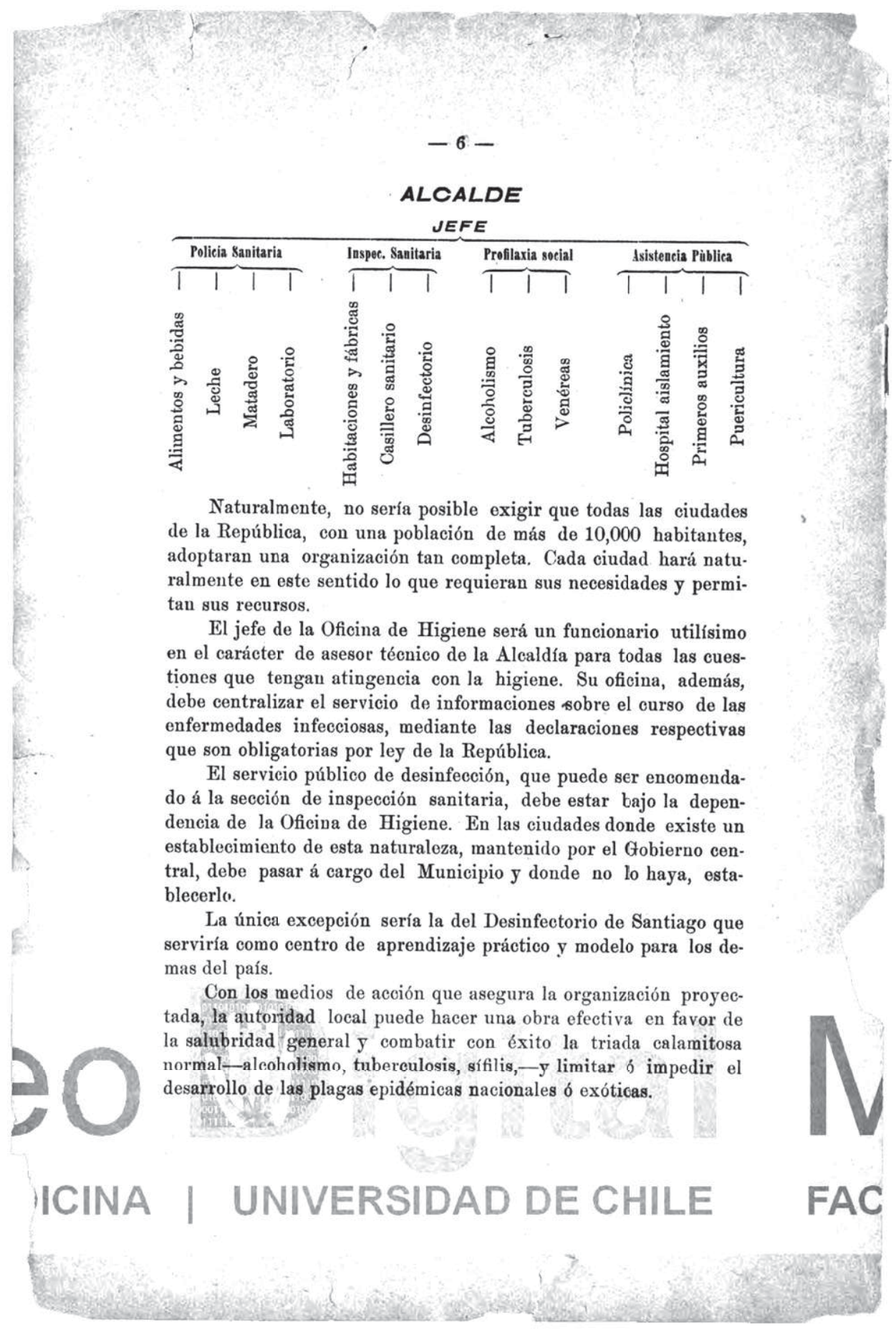




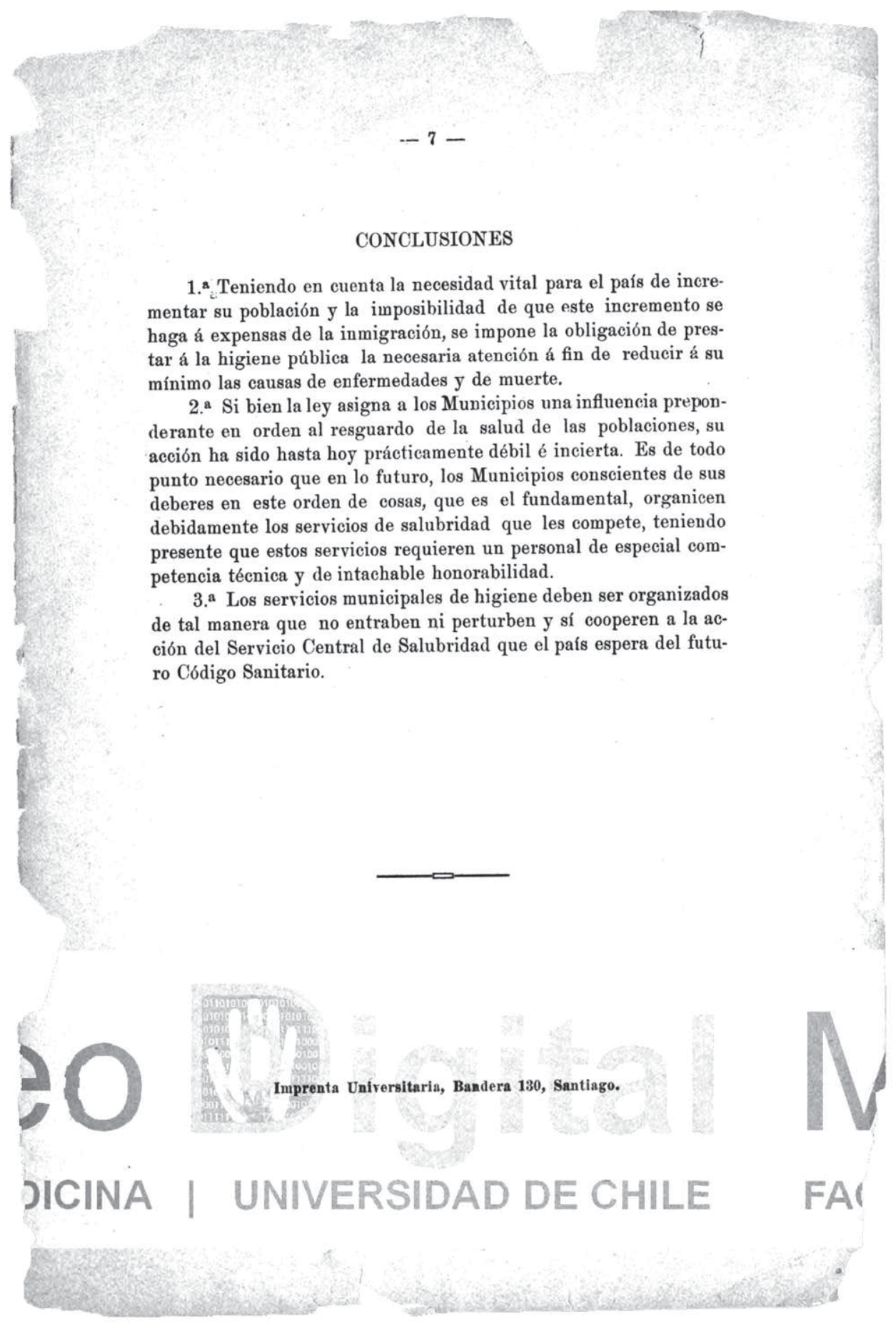




\section{CÓDIGO SANITARIO: LEY N³.385 CONFORME AL DIARIO OFICIAL DE FECHA 22 DE JUNIO DE $1918^{24}$}

Existe cierto consenso en considerar a la Ley $\mathrm{N}^{\circ} 3.385$ como un hito de la historia social y de la salud en Chile, así como el triunfo de una generación de políticos y médicos que, desde la década de 1880, impulsaron el liderazgo estatal en materias de salud pública. Como toda ley, por sí sola no resolvió todos los problemas que abordaba. En la década de 1920, el texto fue objeto de un intento de reforma en tiempos en que Alejandro del Río era el ministro de Higiene y Asistencia Social. Se redactó un nuevo texto en 1925, pero no prosperó el cambio que, hacia 1927, fue evaluado como distante de las costumbres del país. Se generó un nuevo Código Sanitario en el año 1931, diseñado por el renombrado salubrista austriaco Rodolfo Krauss, que rigió hasta 1968, cuando el gobierno del presidente Eduardo Frei Montalva promulgó un nuevo Código, que volvía deber del Estado la protección en materia de salud y bienestar del pueblo.

El centenario del Código Sanitario de 1918 lo relevó como el símbolo de una concepción de la salud pública afianzada en una estructura política, administrativa y científica, pues definió una autoridad central sanitaria, a cargo de la Dirección General de Sanidad, un Consejo Superior de Higiene, un Instituto de Higiene, una Inspección de Boticas, una Oficina Central de Vacunas, una Oficina Central de Desinfección, Servicios Sanitarios Regionales, Consejos Departamentales de Higiene y normas sobre el ejercicio de las profesiones de la salud, higiene alimentaria, animal e industrial, control de infecciones y estadística médica. El nuevo instrumento fue puesto a prueba en una coyuntura como la "gripe española" de 1918, cuya primera oleada se hizo sentir con fuerza en octubre de ese año.

Destacamos el capítulo segundo, titulado "De la policía sanitaria", que refiere a las enfermedades infecciosas como la viruela, la escarlatina, fiebre tifoidea y peste bubónica, y a las medidas que debían tomarse en caso de que ellas se transformaran en epidemias. Estas medidas consistían en el aislamiento de los enfermos y la desinfección, las que, quizás con pocas variantes, siguen siendo las de hoy, aunque en un contexto grave de ausencia de Estado y una concepción de la salud con cargo al individuo y no al colectivo.

24. Chile. Código Sanitario: Ley No3385 conforme al diario oficial de fecha 22 junio de 1918, Santiago, Impr. Central, 1918. Disponible en: http://www.memoriachilena.gob.cl/602/w3-article86318.html 


\section{LEY N.}

\section{CODIGO SAMITARIO}

Conforme al "Diario Oficial" de fecha 22 de Junio de 1918

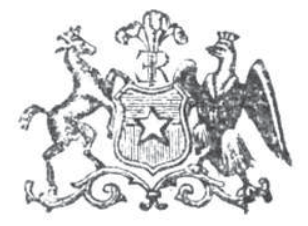

\section{SANTIAGO DE CHILE}

Imp. Central, Bandera 171 - Teatinos 74 - 76 1918 


\section{- $21-$}

la hijiene, como mataderos, mercados, hospitales u otras análogas, sin oir al Consejo Departamental, para lo cual le remitirán los planos, presupuestos y demas datos necesarios.

\section{LIBRO SEGUNDO \\ DE LA POLICLA SANITARIA \\ TÍTULO I}

DE LA PROFILÁxis DE LAS ENFERMEdAdES INFEGGiosas

Art. 52. Todo médico que asista a persona enferma de viruela, escarlatina, difsteria, fiebre tifoidea, tífus exantemático, fiebre amarilla, peste bubónica, cólera morbo, lepra o tracoma, declarará el hecho al jefe de la Oficina de Desinfeccion o a falta de él al gobernador del departamento, dentro de las veinticuatro horass ub-siguientes al diagnóstico cierto o probable de la enfermedad.

Si en caso de epidemia declarada por la autoridad sanitaria, careciere el enfermo de asistencia médica, corresponderá la misma obligacion al dueno de ta casa, o al jefe del establecimiento público o privado en que aquél se hallare.

La infraccion se penará con multa de cincuenta a doscientos pesos y la reincidencia con el doble.

Art. 53. El Presidente de la República, con audiencia del Consejo Superior, podrá hacer estensi- 


\section{$-22-$}

va a otras enfermedades infecciosas la obligacion de que trata el artículo anterior.

Art. 54. En los casos de las enfermedades a que se refieren los artículos anteriores, serán obligatorios el aislamiento del enfermo y la desinfeccion de los locales u objetos que, a juicio de la autoridad sanitaria, estuvieren contaminados.

Se aislará al enfermo en su domicilio, siempre que puedan cumplirse en éste las condiciones del reglamento.

En el caso contrario. se le llevará a un hospital o a otro establecimiento adecuado.

Se observará, con los mismos requisitos, a toda persona que haya tenido comunicacion con algun enfermo o venga de rejion infestada, $u$ ofrezca peligro de contajio. a juicio de la autoridad sanitaria.

La persona que impida el cumplimiento por la autoridad sanitaria de las disposiciones de este artículo, será penada con multa de cincuenta a doscientos pesos.

Art. 55. Las personas que se ocupen en la venta de muebles, ropás. libros u otros objetos usados, deberán hacerlos desinfectar en conformidad a le que determine el reglamento sanitario municipal.

La infeccion será penada con multa de cincuenta a doscientos pesos y la reincidencia con el doble.

Art. 56. Las desinfecciones serán pagadas conforme al arancel que determine el reglamento, y serán gratuitas para los pobres.

Art. 57. Recibirán la vacunacion anti-variólica todos los habitanles de la República en el primer 
año de la vida, y'la revacunacion en el décimo y en el vijésimo respectivamente.

Recibirán, asimismo, el virus anti-variólico, dentro del primer año, a contar desde el dia en que empiece a rejir este Código todas las personas que en esa fecha no hubieren sido vacunadas o revacunadas respectivamente.

Los que quieran eximirse de alguna de las disposiciones de los incisos anteriores deberán declararlo por escrito a la Oficina de Vacuna correspondiente, dentro de los primeros tres meses del respectivo plazo.

Tratándose de incapaces, las incumbencias a que se refieren este artículo scrán de 'cargo a sus representantes legales y, no habiéndolos, a las personas a quienes se haya deferido o que ejerzan de hecho el cuidado personal de los mismos.

Las contravenciones a los dos primeros incisos de este artículo se penarán con multa de diez a cincuenta pesos, sin perjuicio de la vacunacion o revacunacion.

Art. 58. La vacunacion será graluita, y se practicará a domicilio o en los locales que designe la Direccion Jeneral.

Art. 59. Cuando una parte del territorio se viere amagada o invadida por alguna epidemia y los servicios sanitarios municipales fueren insuficientes para detenerla o combatirla, podrá el Presidente de la República, con audiencia del Consejo Superior, designar a alguno de los funcionarios de la Direccion Jeneral para que se haga carco de 


\section{$-24-$}

los servicios jenerales o locales de salubridad en la rejion amagada o invadida.

El funcionario designado adoptará las medidas que juzgue oportunas al cumplimiento de su encargo. dentro de la atribuciones que confiere este Código a las autoridades sanitarias.

Durará en sus funciones por el tiempo que determine el Presidente de la República.

Los gastos que demande la organizacion y desempeño de este servicio serán de cuenta del Estado.

Art. 6o. El reglamento sanitario municipal señalará las medidas de inspeccion, aislamiento y vijilancia médica, referentes a las enfermedades contajiosas que en él se determinen.

Art. 6r. El Presidente de la República con audiencia del Consejo Superior, dictará los reglamentos necesarios para la ejecucion de las demas disposiciones de este título.

\section{TITULO II}

DEL EJERCICIO DE LA MEDICINA Y DE LAS DEMAS RAMAS DEL ARTE DE CURAR Y DE LAS PREPARACIONES DE SUSTANCIAN MEDICINALES

Art. 62. No podrá ejercerse la profesion de médico cirujano, farmacéutico, dentista o matrona, sin título legal.

Prohíbese ejercer conjuntamente las profesiones de médico cirujano y de farmacéution. 


\section{$-25-$}

Prohíbese, asimismo, a los médicos cirujanos ser propietarios de boticas o droguerías, o celebrar cualesquiera convenciones con farmacéuticos o dueños de boticas o droguerías para participar en las uitilidades.

La contravencion a cualquiera de las disposiciones de este artículo se penará con multa de ciento cincuenta a trescientos pesos, y la reincidencia con el doble.

Art. 63. Solo se permitirá despachar recetas o vender medicamentos en las boticas o droguerías.

Es (botica) el establecimiento destinado habitualmente al despacho de preparaciones majistrales 11 oficinales y (droguería) el destinado habitualmente a la venta de medicamentos simples, productos químicos, biolójicos o específicos.

Esceptúase del inciso primero la venta de los remedios de uso doméstico o inofensivo que determine el reglamento.

La contravencion al predicho inciso se penará con multa de ciento cincuenta a trescientos pesos y la reincidencia con el doble.

Art. 64. Prohíbese abrir botica o droguería sin permiso escrito del intendente o gobernador, quien para otorgarlo procederá conforme al reglamento.

Art. 65. Toda botica o droguería deberá ser rejentada por farmacéutico con título legal.

No será lícito a una misma persona rejentar mas de una botica o droguería .

Podra el Presidente de la República, con audiencia del Consejo Superior, reglamentar las con- 


\section{$-{ }_{2} 6-$}

diciones de idoneidad de los demas empleados que hayan de intervenir en el despacho de las recetas. Art. 66. Podrá el Presidente de la República, previo informe de la Direccion Jeneral, autorizar a una o mas personas para abrir botica o droguería en la localidad en que no la hubiere con farmacéutico titulado, bajo las condiciones de idoneidad que determine el reglamento.

Servirá solo esta autorizacion para la localidad que se hubiere designado al concederla; y caducará un año despues de que se establezca en la misma localidad una botica o droguería con rejente titulado.

Art. 67. El rejente y el propietario de botica o droguería serán responsables de la identidad. pureza y buen estado de los medicamentos.

El rejente y el propietario de botica serán tambien responsables de la fidelidad y exactitud en la preparacion de las recetas.

La contravencion a cualquiera de estas disposiciones se castigará con la pena establecida por el artículo 494 del Código Penal.

Si de la infraccion resultare daño a alguna persona, se aplicarán las penas establecidas por el artículo 3 I 5 del mismo Código.

Art. 68. Todo rejente de botica o droguería tendrá a su cargo la direccion técnica del establecimiento y vijilará personalmente el despacho de los medicamentos o recetas conforme al reglamento.

La infraccion se pruará con multa de ciento 


\section{$-37-$}

cincuenta a trescientos pesos y la reincidencia con el doble.

Lo dicho en este artículo no obsta a la responsabilidad de los demas empleados que hayan intervenido en el despacho de las recetas.

Art. 69. Sólo podrán espedir recetas, las personas que tengan título para ejercer una profesion u oficio relacionado con el arte de curar, conforme al reglamento.

Sólo con órden escrita de médico cirujano podrán espenderse los medicamentos que califique de peligrosos la Farmacopea Nacional.

Las sustancias peligrosas destinadas a usos industriales no podrán espenderse sino conforme a las disposiciones respectivas del reglamento,

La contravencion a cualquiera de estas disposiciones se castigará con arreglo al artículo $3 \mathrm{~s} / 4$ del Código Penal.

Art, 70. Prohibese la venta de cualesquiera preparaciones farmacéuticas, cuyas fórmulas no estén impresas en las envolturas inmediatas que las contengan, salvo que se trate de invenciones o procedimientos orijinales, caso en el cual deberán depositarse las fórmulas en la Direccion Jeneral, conforme a un reglamento que dictará el Presidente de la República, con audiencia del Consejo Superior,

La infraccion se castigará con la pérdida de las especies, sin perjuicio de las penas a que se refiere el artículo i 3 del Código Penal.

Art. 7I. Si no hubiere en un lugar mas que 


\section{$-{ }_{2} 8-$}

una botica, atenderá ella personalmente al público,

Si hubiere mas de una, señalará el intendente o gobernador el turno semanal a que hayan de sujetarse en las noches y en los dias feriados.

El turno en las noches se entenderá establecido sólo respecto de las recelas o medicamentos.

Art. 72. Ordenará el intendente o gobernador la clausura de toda botica o droguería en que se haya infrinjido alguna de las disposiciones de los artículos 64,65 y 7 1, y podrá conceder un plazo improrrogable de veinte dias para que se subsane el defecto si hubiere lugar a ello, sin perjuicio del derecho del interesado para ocurrir al juez, quien resolverá breve y sumariamente, oyendo a las partes,

Art, 73. Una comision compuesta del Director Jeneral, que la presidirá, de los profesores de farmaria y química analitica de la Universidad de Chile, respectivamente, de un farmacéutico designado por el Consejo Superior, y de los miembros de la inspeccion de boticas, revisará cala cinco años la Farmacopea Nacional, y dirijirá la edicion oficial de la misma.

Art. 74, Para instalarse o funcionar los institutos o laboratorios particulares dedicados a preparar vacunas, sueros u otros ajentes biológicos de an loga naturaleza y las fáb.icas de productos quimicos o farmacéuticos, se someterán al reg̣lamento que dicte el Presidente de la República, con audiencia del Consejo Superior, 


\section{$-29-$}

La contravencion se penará con muita de seiscientos pesos, sin perjuicio de la clausura del lnstitulo, laboratorio o lábrica.

Art, 75, El Presidente de la Riepública con informe del Consejo Superior dictará un reglamento de boticas y droguerías,

Podrá tambien con informe del mismo Consejo dictar reglas sobre los requisitos de Vejitimidad, pureza, innocuidad, envase y venta de las sustancias a que se refiere el artículo precedente.

\section{TÍTLLO III}

DE LA SALUBRIDAD DE LAS POBLACIONES

Art. 76. No podrán ejecutarse los trabajos de agua potable alcantarillas o desagues de las poblaciones sin que el Presidente de la República apruebe los planos y especificaciones, previo informe de la Direccion Jeneral de Obras Públicas y de la Direccion Jeneral de Sanidad.

Art. 77, El Presidente de la República previo informe del Consejo Superior y con acuerdo del Consejo de Estado reservará en las corrientes naturales de uso público las aguas necesarias para el abastecimiento de las poblaciones.

Con los mismos requisitos determirá los derímetros de proteccion correspondientes,

En estos casos se procederá, en conformidad al número 3 , ${ }^{\circ}$ del artículo 835 del Código Civil.

Art. 78. El Presidente de la República, previo 


\section{$-3 \mathrm{o}-$}

informe del Consejo Superior, y con acuerdo del Consejo de Estado, dictará una ordenarza jeneral para mantener la pureza de las aguas destinadas al abastecimiento de las poblaciones.

Art. 79. Los dueños de propiedades particulares están obligados a permitir sin indemnizacion alguna, las obras necesarias para la colocacion de las cañerías de agua potable y la construccion de las obras de alcantarillado que beneficien a sus respectivas propiedades.

Art. 8o. Las empresas de agua potable deberán proporcionar gratuitamente el agua necesaria para los eslablecimientos de beneficencia y para las escuelas o colejios de instruccion gratuita.

Art. 81. Terminada la construccion del alcantarillado público, o de alguna seccion del mismo, los propietarios deben hacer a sus espensas las instalaciones domiciliarias, y las conexiones de ellas con las cañerías matrices, previa la aprobacion de los planos y especificaciones por la Direccion del Alcantarillado, y dentro del plazo que scìale el reglamento.

No podrán ser utsakas las instalaciones sin que la direccion del servicio haya aprobado las obras, y aulorizado el desague,

Si lo fueren, omitiéndose alguno de estos requisitos, ordenará la Direccion que se interrumpan las coneviones a espensas de los infractores,

Deberán asimismo los propictarios cegar dentro de sus respectivos predios, y a sus espensas, los pozos, acequias o acueductos con que se hubiere 


\section{$-3 \mathrm{I}-$}

hecho anteriormente el servicio, en el plazo y con los requisitos que señale el reglamento.

La propiedad en que se infrinja alguna de las disposiciones de los incisos primero y tercero de este artículo, será claustirada por el intendente o gobernador; y sin perjuicio de mantenerse entre tanto la medida podrá el interesado ocurrir al juez, quien resolverá breve y sumariamente y en única instancia, oyendo a las partes.

Art. 82, El reglamento sanitario municipal establecerá las demas reglas concernientes a la salubridad de las poblaciones.

\section{TITULO IV}

DE LA SALUBRIDAD DE LOS EDIFICIOS

Art. 83. En ninguna poblacion podrá construirse ni reconstruirse total o parcialmente un edificio sin permiso escrito del alcalde quien no lo concederá sin haberse cerciorado de que los planos y especificaciones cumplen con los requisitos del reglamento sanitario.

La infraccion se penará con multa de ciento a doscientos pesos, sin perjuicio de la suspension administrativa de la obra hasta que se obtenga el permiso.

Art. 84. Al término de la obra, deberá cerciorarse el alcalde si se han cumplido las disposiciones sanitarias correspondientes y en caso contrario, será penado el infractor con multa de ciento a 


\section{$-3_{2}-$.}

d- scientos pesos y se ordenará la clausura del edificio hasta que se cumplan.

Art. 85. Si denegare el alcalde alguna de las solicitudes a que se refieren, respectivamente, los dos artículos anteriores, o. no las proveyere dentro de un plazo de quince dias, desde la presentacion de las mismas, podrá el interesado reclanar ante el juez de letras, quien resolverá breve y sumariamente, oyendo a las partes.

Art. 86. Podrí el alcalde, previo informe del jefe de la Oficina de Ilijiene, donde la hubiere, declarar inhabitable o insalubre un edificio, conforme al reglamento.

Art. 87. Calificado un edificio de inhabitable o insalubre por el alcalde, comunicará éste el hecho por escrito al dueño, remitiéndole copia del informe del jefe de la Oficina, si lo hubiere, e indicíndole el costo aproximado de la demolicion o de las reparaciones, y el plazo para llevar a efecto la obra, que no podrá exceder de noventa dias.

Art. 88. Si no se ejecutaren dentro del plazo señalado la demolicion o las reparaciones, lo comunicará el alcalde por escrito al juez de letras, acompañándole los antecedentes; y el juez citará, dentro del tercero dia, al dueño o a su mayordomo, y resolverá sin mas trámite.

Si no excediere de quinientos pesos el valor de la obra, conforme a la estimacion indicada en el artículo anterior, será inapelable el fallo.

Art. 89 . El edificio que hubiere sido judicialmente declar do inhabitable o insalubre, deberá 
clausurarse o demolerse dentro del término que indique la sentencia.

Si no se diere cumplimiento a lo prescrito en el inciso anterior, procederá la Alcaldía sin mas trámite a la clausura o demolicion.

Se ejecutará la demolicion con cargo al dueño; y podrá entablarse accion ejecutiva en su contra por el monto del presupuesto a que se refiere el artícu lo 87 .

Art. 9o. El edificio insalubre podrá ser rehabilitado por declaracion del alcalde, previo informe de la Direccion de Obras Vumicipales, que acredite el cumplimiento de las indicaciones hechas por la autoridad sanitaria .

Art. 9I. Si el propietario u ocupante se opusiere a la visita sanitaria, podrá el alcalde ocurrir al juez, quien señalará inapelablemente el dia y hora de la visita.

Art. 92. El Presidente de la República dictará, con audiencia del Consejo Superior, un reglamento sobre las condiciones sanitarias que deben tener los edificios destinados al uso público.

Art. 93 . El reglamento sanitario municipal determinará las condiciones hijiénicas que hayan de cumplir los demas edificios y las reglas a que deban someterse las municipalidades para llevarlas a efecto.

Art. 94. Quedan en vigor las disposiciones de la ley de 20 de lebrero de Igo6, sobre habitaciones para obreros; y en particular las concernierites a las atribuciones esclusivas de los consejos, 


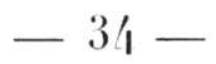

establecidos o que se establezcan en lo fuluro conforme a la misma les,

En consecuencia, las disposiciones de este título no se aplicarín respecto de las habilaciones para obreros. rejidas por la citada ley de so de febrero de 1 s,ot.

\section{TITULO V}

DE IA HIJENE ALIMENTICIA

Art. 95. Prohíbese la introduccion en el pais de sustancias alimenticias adulteradas o nocivas.

EI Presidente de la República, con informe del Consejo Superior, determinará las sustancias que deben incluirse en cada una de las calificaciones anteriores.

La infraccion se castigarí con la pérdida de las especies, sin perjuicio de las penas señaladas en el articulo 3 i 6 del Código Penal.

Arl. 96. El reglamento sanilario municipal determinará las condiciones de lejitimidad, pureza, innocuidad, envase y demas requisitos hijiénicos que deban cumplir Íos artículos alimenticios para ser entregados al consumo.

Sce castigarán las infracciones conforme al últ:mo inciso del artículo precedente.

Senalará, ademas, el reglamento las circunstancias en que deban los comerciantes suministrar las muestras alimenticias, $y$ las penas en que incurran los infractores. 


\section{$-35-$}

\section{TITULO VI}

DE LA HIJIENE INDUSTRIAL

Art. 97. No podrín instalarse dentro del recinto urbano de las poblaciones las industrias que el reglamento sanitario califique de peligrosas,. insalubres, o notablemente incómodas.

Art. 98. Determinará el reglamento las condiciones hijiénicas a que haya de sujetarse el trabajo, y especialmente el de las mujeres o menores de dieciocho años, en los establecimientos industriales.

Art. 99. El alcalde, previo informe del jefe de la Oficina de Hijíene, donde la hubiere, ordenará la clausura de todo establecimiento en que se hayan. infrinjido las disposiciones legales o reglamentarias; sin perjuicio del derecho del dueño para ocurrir al juez, quien resolverá breve y sumariamente, oyendo a las partes.

Art. ioo. El alcalde o el jefe de la Oficina de llijiene podrá ordenar visitas de inspeccion a todo establecimiento industrial.

Art. ior. El propielario o tenedor de un establecimiento que se opusiere a la visita sanitaria ordenada por autoridad competente, incurrirá en una multa de ciento cincuenta a trescientos pesos, que se doblará en caso de reincidencia.

\section{TÍTULO VII}

DE LA POLICIA SANITARIA MARITIMA Y DE LAS FRONTERAS Art. ro2. Toda nave que arribe a un puerto de la 
República, recibirá la visita de la autoridad sanitaria, ántes de ser admitida a libre plática.

El capitan de la nave, o el conductor de un tren que venga del estranjero, denunciará inmediatamente a la autoridad sanitaria todo caso de enfermedad infecciosa que haya ocurrido durante el viaje.

El capitan denunciará tanbien inmediatamente a la autoridad sanitaria todo caso de enfermedad infecciosa que ocurra en la nave durante su estadía en el puerto.

La contravencion será penada con multa de trescientos a seiscientos pesos, y la reincidencia con el doble.

Art. ro3. Si la nave o el tren estuviere infestado, o fuera sospechoso de estarlo, a juicio de la autoridad sanitaria, rejirán las disposiciones respectivas del reglamento.

Art. ı 4. La nave, cuyo estado sanitario se califique de peligroso por la autoridad competente, quedará sujeta a las precauciones especiales, que determine el reglamento.

Art. ı05. Se entenderán infestadas o sospechosas las rejiones de los paises que hayan sido declaradas tales por el Presidente de la República, prevịo informe del Consejo Superior, y las de los paises estranjeros que lo hayan sido por sus respectivos gobiernos.

Art. 106. Las medidas de profiláxis internacional en los puertos de la República consistirán en la espedicion de patentes o pasaportes de sanidad. en las visitas e inspecciones sanitarias de las naves 


\section{$-3_{7}-$}

o trenes, en el aislamiento de los enfermos, en la observacion o vijilancia médica de los pasajeros, en la desinfeccion de las naves o trenes y de las especies y en la destruccion de los animales infestados.

Art. 107. Las medidas de profiláxis a que se reficre el artículo anterior se sujetarán al reglamento de policía sanitaria marítima y de las fronteras.

Art. io8. Todo cónsul de la República que estuviere ejerciendo sus funciones en una localidad infestada de peste bubónica, cólera morbo, fiebre amarilla, comunicará teleǵráficamente al Gobierno la aparicion y el desarrollo de la epidemia.

Tratándose de un puerto que se halle en el caso del inciso anterior, comunicará tambien el cónsul telegráficamente al Gobierno la salida de cualquiera nave de ese puerto para Chile.

Art. Io9. Los emolumentos por servicios de sanidad marítima y de las fronteras, o por gastos de alojamiento obligatorio de pasajeros, seran delerminados por un arancel que dictará el Presidente de la República, previo informe del Consejo Sup orior.

Art. i ro. El Presidente de la República, con audiencia del Consejo Superior. dictará el reglamento de policía sanitaria marítima y de las fronteras.

Podra tambien, con audiencia del mismo Consejo, dictar reglas para impedir la entrada en el pais de personas que padezcan enfermedades crónicas contäjosas, o vicios orgánicos incurables. 


\section{$-38-$}

\section{TITULO VIII}

DE LA POLICIA SANITARIA DE LOS ANIMALES

Art. I I I. Prohíbese internar en el pais animales atacados de enfermededes contajiosas, o que ofrezcan sospechas de estarlo.

Podrá el Presidente de la República ordenar la clausura de los puertos marílimos o terrestres para asegurar el cumplimiento del inciso anterior.

Los animales internados en contravencion en el mismo inciso, serán devueltos al lugar de su oríjen: o sometidos al tratamiento sanitario correspondiente.

No siendo posible aplicar tales medidas, el jue\%, a solicitud del gobernador, y previa informacion snmaria, ordenará el sacrificio de los animales enfermos, a costa del propietario o tenedor, y sin derecho a indemnizacion.

Contra esta providencia no cabrá recurso alguno.

Art. I 12. El dueño o guardador de animales atacados por enfermedades contajiosas, o que of re\%can sospechas de estarlo, denunciará inmediatamente el hecho al gobernador del departamento. manteniéndolos miéntras tanto encerrados y aislados.

Todo ello bajo las sanciones que determinan los artículos 289, 290 y 29 I del Código Penal.

Art. 1 13. El Presidente de la República, previo informe del Consejo Superior, dictará un reglame to que determine la enfermedades a que se re- 


\section{$-3_{9}-$}

fieren los artículos anteriores, y las medidas de profiláxis relativas al aislamiento, desinfeccion y sacrificio de los animales enfermos, y destruccion de las especies contaminadas.

\section{TITULO IN}

DE LA POLICIA MORTUORIA

Art. 1 14. Habrá en cada territorio municipal un cementerio, a lo ménos.

Art. i I5. Solo podrá establecerse un cementerio o ensancharse uno establecido, con aulorizacion del Presidente de la República, previo informe del Consejo Superior; pero para denegar la autorizacion le será necesario, ademas, el acuerdo del Consejo de Estado.

Art. i 6 . Solo se permitirán las inhumaciones en los cementerios públicos, o en los privados o parroquiales que en la actualidad existan; o que autorice el Presidente de la República, conforme al artículo anterior; pero podrán sepultarse en las catedrales los cadáveres embalsamados de los obispos.

Art. I 7 . No se permitirán ninguna inhumacion ántes de las veinticuatro horas subsiguientes a la muerte.

Art. i i 8. No podrá ser conducido a ningun templo para los oficios relijiosos el cadáver de una persona que haya muerto de viruela. cólera-morbo, peste bubónica o tifus exantemático.

Art. i ig. Para transladar un cadáver de un lu- 


\section{$-40-$}

gar a otro de la República, será necesario permiso escrito de la autoridad administrativa del primero de esos lugares, conforme al reglamento.

Art. I 20. No se permitirá la exhumacion ántes de que el cadáver esté reducido a osamenta, y en ningun caso, ántes de los diez años subsiguientes a la inhumacion.

No está sujeta al inciso anterior la exhumacion que autorice al Presidente de la República, o que ordene la autoridad judicial.

Art. 12 I. Podrá ordenar el Presidente de la República la clausura de cualquier cementerio que se establezca sin el permiso competente. o que, a su juicio, ofrezca manifiesto peligro para la salud pública.

En el segundo de estos casos deberá proceder con el informe del Consejo Superior y con acuerdo del Consejo de Estado.

Art. 122. No se permitirán las sepultaciones sobre el nivel del suelo en los cementerios qne se establezcan en Io futuro.

Art. 123. El Presidente de la República, previo informe del Consejo Superior, dictará un reglamento para la ejecucion de las disposiciones de este título.

\section{TITULO X}

DE La estadístiga Mécica

Art. 124, La Oficina Central de Estadística co- 
municará mensualmente al director del Instituto de Hijiene los datos concernientes a los nacimientos, matrimonios y defunciones inscritas en sus libros durante el mes anterior.

Los estadísticos de los establecimientos de beneficencia pública o privados comunicarán tambien, el primero de cada mes, al director del Instituto, el resúmen de la estadística respectiva del mes anterior.

La contravencion será castigada con una multa de cincuenta a cien pesos, que se doblará en caso de reincidencia.

Art. 1 25. El director del Instituto podrá solicitar de las oficinas públicas las demas informaciones que estime útiles para completar la estadística médica.

El jefe de oficina que negare los datos sufrirá una multa de cincuenta a cien pesos, que se doblará en caso de reincidencia.

Art. I 26 . Un reglamento que dicte el Presidente de la República, previo informe del Consejo Superior, determinará, en lo demas, las condiciones de este servicio.

\section{TÍTULO XI}

\section{DISPOSICIONES JENERALES}

Art. I 27. Toda infraccion penal de la ley sanitaria se persiguirá de oficio y conferirá accion popular. 


\section{RECOPILACIÓN OFICIAL DE LEYES I DECRETOS RELACIONADOS CON EL MINISTERIO DE HIJIENE, ASISTENCIA I PREVISIÓN SOCIAL I TRABAJO ${ }^{25}$}

El abogado Moisés Poblete Troncoso realizó un importante y poco reconocido trabajo de recopilación de la legislación laboral chilena y latinoamericana entre los años 1920 y 1950. Fue director, entre 1920 y 1925, de la Oficina del Trabajo, y en tanto administrador público redactó el Código Laboral presentado al Congreso en 1921 por el gobierno de Arturo Alessandri. Además, cumplió una labor relevante en la Organización Internacional del Trabajo entre 1927 y 1937. Sus aportes al estudio del movimiento obrero en América Latina son cruciales, en particular su libro publicado en 1946, titulado El movimiento obrero latinoamericano, el que tuvo amplia influencia sobre investigaciones posteriores.

En 1924 se creó el Ministerio de Higiene, Asistencia y Previsión Social, que tenía por objetivo atender los graves problemas que vivía el país en materias de organización de la sanidad, la asistencia social, la organización del trabajo y la previsión social. El presente boletín fue emitido en mayo de 1927 por dicho ministerio, con el fin de divulgar entre las personas el quehacer de esta institución, sus subdivisiones, objetivos, y educar sobre la legislación sanitaria, social y laboral.

En este número destaca la cuenta de la Dirección General de Sanidad en torno a las tareas realizadas para contrarrestar la mortalidad infantil, la cantidad de vacunas inoculadas y las estadísticas de contagiados y fallecidos por enfermedades como la escarlatina, el tifus y la fiebre tifoidea. También observamos la preocupación de la Dirección General del Trabajo por reubicar a la enorme masa de obreros que quedaron cesantes tras la paralización de las salitreras. Esta Dirección también se preocupó de visitar las fábricas y otros establecimientos de trabajo para resguardar que se cumplieran las disposiciones de la legislación social, entre ellas, el Decreto de Ley N442 sobre Protección a la Maternidad Obrera del 20 de marzo de 1925. Era este un aspecto con el cual el recopilador tenía especial relación desde su tesis como abogado, dedicada a la Legislación sobre bijos ilegítimos (cuestión social) (Santiago, Imprenta El Progreso, 1912). Este decreto instauraba el periodo de pre y posnatal,

25. Ministerio de Hijiene, Asistencia, Previsión Social i Trabajo. Recopilación oficial de Leyes i Decretos relacionados con el Ministerio de Hijiene, Asistencia, Previsión Social i Trabajo, Santiago de Chile, Imprenta Santiago, 1925. Disponible en: http://www.memoriachilena.gob. $\mathrm{cl} / 602 / \mathrm{w} 3$-article-9289.html 
la protección del empleo, la lactancia materna y las salas cunas en toda fábrica o establecimiento con 20 o más mujeres empleadas.

El ministerio desapareció tras una reestructuración que derivó en la creación del Ministerio de Bienestar Social a fines de 1927. Ya estaba vigente la Constitución de 1925, que en el capítulo III, de las garantías constitucionales, asegura, en el artículo $14^{\circ}$, la protección al trabajo, la previsión social, la habitación y un mínimo bienestar a cada habitante. El deber del Estado era velar "por la salud pública y el bienestar higiénico del país". 
Ministerio de Hijiene, Asistencia, Prevision Social i Trabajo

Recopilacion oficial de leyes i decretos relacionados

$\operatorname{CON} \mathrm{EL}$

MINISTERIO DE HIJIENE, ASISTENCIA

I PREVISION SOCIALI TRABAJO

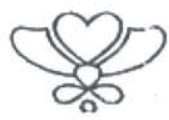

SANTIAGO DE CHILE

IMPRENTA SANTIAGO.-SAN ANTONIO 674 1925 


\section{INTRODUCCION}

La segunda etapa de la obra del Ministerio de Hijiene, Asistencia, Prevision Social i Trabajo, se caracteriza por la intensidad de los problemas sociales que hubo de abordar i resolver, dada la crísis que estos problemas vitales produjeran en la vida política del pais.

La accion administrativa del Ministerio se ha intensificado enormemente por esta misma causa, lo que hizo indispensable la sub-division de la SubSecretaria que atendía primitivamente la parte de Hijiene, Asistencia, Prevision Social i Trabajo, en los dos departamentos uno de Hijiene i Asistencia Social i otro de Prevision Social i Trabajo.

El problema de la vivienda insalubre, cara e insuficiente, hizo crísis en el primer mes del año.

Los arrendatarios se organizaron en todo el pais para pedir a los Poderes Públicos una solucion inmediata del problema de la carestía e insuficiencia de los alquileres.

El Gobiermo, sin desconocer el aspecto integral del problema de la habitacion económica, se vió en la ntcesidad de dictar una lei de emerjencia, relacionada con la carestía de las habitaciones, adoptando la misma pulítica seguida en Arjentina i en los paises europeos en casos semejantes.

Inmediatamente de dictada esta lei, el Ministerio 
hubo de encarar el problema fundamental, o sea, el fomento de la construccion de habitaciones baratas.

Después de un detenido estudio, i con la colaboracion de técnicos en la materia, se ha dictado la lei mas trascendeutal de carácter social que garantiza la inversion de grandes sumas de dinero en la edificacion de casas para obreros i empleados.

Junto con este problema se presentó el de la modificacion de la Lei de Empleados Particulares, solicitada por los empleados organizados en Chile que hicieron un activo movimiento de accion social.Esta lei fué estudiada detenidamente con los propios empleados que indicaron las reformas que estimaban convenientes i que fueron materia de un nuevo Decreto-lei que vino a acallar las protestas de los empleados.

Se ha dictado una lei que proteje a la maternidad obrera i que ha significado un paso trascendental en favor de la mujer asalariada.

Respecto de la accion de mejorar las condiciones de hijiene pública se dictó un importante Decretolei llamado de Defensa de la Raza que crea la Division de Hijiene Social con todos los organismos necesarios para el ataque control i curacion de las enfermedades sociales en la República.

Esta lei, es una de las importantes desde el punto de vista de Hijiene Pública de las que se han dictado en Chile.

Se dictó así mismo, una Lei que hace estensivo a las peluquerias el descanso dominical obligatorio.

Se ha dictado así mismo un Decreto-lei que com. plementa la Lei de Accidentes del Trabajo N. 4055 que adolecía de varias contradicciones i que hace mas viable su aplicacion.

Finalmente se dictó un reglamento especial de 
la Direccion Jeneral del trabajo que determina las obligaciones de este uuevo organisino.

Esta es en síntesis, la obra realizada por este Ministerio en este segundo período de su existencia. Ella ha correspoudido al Ministro, don José S. Salas, que con una comprension clara del problema social, con un estudio atento de los diversos factores en el terreno mismo de los hechos. i con una conviccion profunda de la necesidad de encararlos i resolverlos, ha llevado a feliz término la solucion de estos problemas latentes durante muchos años en la vida de la República.

Morses Poblete Troncoso. 


\section{Decreto-lei Núm. 442}

Santiago, 20 de Marzo de 1925.

La Junta de Gobierno, de acuerdo con el Consejo de Secretarios de Estado, ha acordado i dicta el siguiente:

\section{DeCRETO-LEI}

\section{De la Proteccion a la Maternidad Obrera}

Artículo $10^{\circ}$ Las obreras durante el período del embarazo, tendrán derecho a un descanso que comprenderá, cuarenta dias ántes del alumbramiento i veinte dias después.

Durante este período el patrono o empresario es. tará obligado, no obstante cualquiera estipulacion en contrario, a reservarle el puesto i a pagarle el $50 \%$ del salario.

Art. 2. ${ }^{\circ} \mathrm{El}$ patron no podrá, sin justa causa, des. pedir a la obrera embarazada.

No se entenderá que es justa causa el menor rendimiento de la obrera para el trabajo en razon del embarazo.

El estado de embarazo se entenderá comprobado por el certificado de cualquier médico o matrona o del médico de la Direccion General del Trabajo.

Art. 3. ${ }^{\circ}$ Toda fábrica, taller o establecimiento industrial o comercial que ocupe veinte o mas mujeres de cualquiera edad o estado civil, deberá dispo. ner de una sala,"acondicionada en la forma que señala el Reglamento respectivo, para recibir en las horas de trabajo a los hijos de las obreras durante el primer año de edad. 
Las disposiciones de este Decreto-lei se aplican a todas las fábricas, talleres o establecimientos indus. triales o comerciales, aunque pertenezcan a personas jurídicas o estén destinados a fines de beneficencia o pertenezcan a instituciones de derecho público.

Art. $4 .^{\circ}$ Las madres a que se refiere el artículo anterior tendrán derecho a disponer, para amaman. tar a sus hijos, dos porciones de tiempo, que en conjunto no excedan de una hora al dia.

El valor de este tiempo no podrá ser descontado del salario de la madre, cualquiera que sea la forma de remuneracion, i el derecho de usar de este tiempo con el objeto indicado, no podrá ser renunciado en forma alguna.

Art. $5 .^{\circ}$ Las fabricas que ocupen mujeres deberán entregar a cada obrera, una libreta, en que se contenga el texto de esta Lei; i deberá colocar carteles en los diversos talleres con las mismas disposiciones.

Art. 6. ${ }^{\circ}$ Cada infraccion de este Decreto-lei o a su Reglamento será penado con multa de cien a quinientos pesos, que depositarán en la Tesoreria Fiscal en una cuenta especial para formacion de un fondo destinado a socorrer la maternidad obrera, el que se distribuirá en la forma que ordene el Presidente de la República.

La reincidencia se castigará con multa de quinientos a mil pesos i dará derecho a pedir la clausura del establecimiento.

Art. 7. ${ }^{\circ}$ Los empleados de la Direccion General del Trabajo, tendrán derecho a visitar, cada vez que lo estimen conveniente, las fábricas i talleres que ocupen mujeres, i darán aviso al Director General de las incorrecciones que noten en la aplicacion de esta Lei o del Reglamento respectivo. 
Art. 8. ${ }^{\circ}$ Toda persona legalmente capaz que tu. viere conocimiento de la infraccion de cualquiera de las disposiciones de la presente Lei o de su Reglamento, podrá denunciarla ante la Direccion General del Trabajo, a fin de que esta proceda a la comprobacion respectiva.

Art. 9. ${ }^{\circ}$ Hecho el denuncio, el Director General del Trabajo deducirá por si o por apoderado, la acusacion correspondiente ante el Juez Letrado del Crímen que corresponda.

Art. 10. Para que el denunciado pueda deducir cualquiera clase de defensa, deberá préviamente consignar en la Tesoreria Fiscal, a la órden del Juez, el valor de la inulta indicado en la demanda.

Art. 11. Efectuado el comparendo, o en rebeldía del denunciado, el Jue\% dictará sentencia inmediatamente o a mas tardar dentro de las cuarenta i ocho horas siguientes.

Art. 12. Durante la secuela de estos juicios no habrá apelacion.

Todas las dilijencias o actuaciones gozarán de preferencia por parte de todos los funcionarios del órden judicial i tambien de todos los Tribunales.

Los denunciantes gozarán de privilejio de pobreza.

Art. 13. Toda persona que tuviere conocimiento de la infraccion de cualquiera de las disposiciones de la presente Lei o Reglamento, podrá denunciarla ante la autoridad competente, a fin de que ésta proceda a la comprobacion respectiva.

Las Policías prestarán toda su ayuda a la Direccion del Trabajo para el cumplimiento de las obligaciones que le impone este Decreto-Lei.

Art. 14. Se declara que esta Lei es de amplia proteccion a la maternidad i a la infancia. 
Art. 15. El Presidente de la República dictará un Reglamento para la aplicacion de la presente Lei.

Art. 16. Derógase la Lei $\mathrm{N} .{ }^{\circ} 3185$, de 13 de Febrero de 1917.

La presente Lei empezará a rejir sesenta dias después de su publicacion en el Diario Oficial.

Tómese razon, comuníquese, publíquese e insértese en el Boletin de las Leyes $i$ Decretos del Gobierno.-Emilio Bello C.-C. A. Ward.-Pedro P. Dartnell.-J. S. Salas. 


\section{¿EN QUÉ CONSISTE EL DESAYUNO ESCOLAR? ${ }^{26}$}

Tanto para resolver el problema sanitario como para ampliar la cobertura escolar, profesores y médicos comenzaron a plantear la urgencia de responder a las necesidades materiales de la población escolar en situación de pobreza. Varias obras filantrópicas crearon comedores escolares y en 1908 surgió la primera olla infantil, iniciativa que se multiplicaría y daría origen a la Sociedad de Ollas Infantiles. Eloísa Díaz estuvo entre las más activas promotoras del desayuno escolar, tal como Pedro Bannen lo fue en la creación de escuelas proletarias.

Al esfuerzo de las organizaciones filantrópicas se sumó el aporte estatal a través de un sistema de subvenciones, pero la Ley de Instrucción Primaria Obligatoria (1920) no aseguró el aporte esperado y solo creó juntas comunales de auxilio que financiaban parcialmente la distribución de alimentos (leche, ulpo, aceite de bacalao) y la organización de cantinas y comedores escolares. Con el Frente Popular se amplió la entrega de alimento, ropa y calzado, pero las necesidades estaban lejos de ser satisfechas.

En 1953 se creó una Junta Nacional de Auxilio Escolar, pero la entrega masiva de recursos se inició recién a partir de 1964, cuando el gobierno de Frei Montalva dio prioridad a la expansión de la cobertura escolar. Esta política alcanzó su punto culminante durante el gobierno de Salvador Allende, a través del programa de distribución a los escolares de medio litro de leche al día.

26. Consejo Nacional de Alimentación (Chile). ¿En qué consiste el desayuno escolar?, Santiago, Imprenta Cultura, 1939. Disponible en: http:/ /www.memoriachilena.gob.cl/602/w3-article-9371.html 
MINISTERIO DE SALUBRIDAD, PREVISION Y ASISTENCIA SOCIAL

CONSEJO NACIONAL DE ALIMENTACION

\title{
¿En qué consiste
}

el

desayuno escolar?

\author{
DIFUSIQN N.O 3 \\ GO DE CHILE \\ 1939
}




\section{INTRODUCCION}

El Desayuno Escolar está establecido desde muchos años en nuestra legislación, y en la práctica, se suele proporcionar a los niños "desnutridos" de Escuelas Primarias algún alimento que se conoce con ese nombre. En efecto, las Juntas de Auxilio Escolar, creadas por Decreto N. 5319 , del 31 de octubre de 1938, reciben fondos provenientes especialmente de aportes municipales y fiscales con el objeto de ser destinados a la realización del objeto, que aparece explícitamente expresado en el art. $1 .^{\circ}$ de su Reglamento, dictado por Decreto $N .^{\circ} 6.354$, de 31 de diciembre de 1929 .

"Las Juntas de Auxilio Escolar tienen por objeto " mantener el control y vigilancia de cumplimiento de la " obligación escolar dentro de su respectiva comuna, sin " perjuicio de la responsabilidad que incumbe a los funcio" narios del serricio; procurar la difusión de la educación " popular, $y$, de un modo preferente, promover y organizar "los servicios de asistencia escolar de los alumnos de las "Escuelas Públicas".

Estas Juntas han considerado, en general, que su labor debe consistir en proporcionar a los niños provenientes de hogares en estado de miseria, alimentación y vestido para que puedan asi concurrir a clases, y se ha designado con el nombre de Desayuno Escolar el alimento que a ellos se proporciona. 


\section{$-2-\quad$.}

Dada la poca cantidad de dinero de que disponen estas Juntas y el número de niños que aparecen como acreedores a recibir este Desayuno, su constitución ha estado siem pre determinada por aquel alimento que siendo más barato proporcione la sensación de haber comido bastante. Es así cómo la infusión de café de malta con azúcar, el "ulpo" cn agua con azúcar, el pan, etc., han constituido el menú mís frecuente de este desayuno.

Es obiio que aquellos alimentos que resultan más baratos para la Junta de Auxilio Escolar son también los que pueden adquirir con mayor facilidad un hogar pobre, o sea, son aquellos que constituyen el alimento de consumo habitual en sus casas. Un desayuno escolar así constituído no hace sino agregar una pequeña proporción de alimentos de exclusivo valor energético y nulo valor protector, como son los enumerados y no resuelve ningún defecto del régimen alimenticio del niño. 


\section{¿QUE SE PRETENDE CON EL DESAYUNO ESCOLAR?}

Para decidir en qué debe consistir un desayuno escolar, es necesario plantear primero qué se pretende obtener de él.

Nos parece evidente que la constitución de un Desayuno Escolar en forma oficial debe tener por objeto conseguir que al lado del desarrollo psíquico normal que se obtiene por medio de la Educación Primaria, los niños tengan un desarrollo físico también normal, que sćlo puede conseguirse por medio de una alimentación apropiada y de un ejercicio físico bien dirigido.

De aquí que el término de Desayuno Escolar resulte inapropiado, porque significa un alimento que se proporciona en las mañanas, siendo que para cumplir ese desideratum no tiene importancia la hora en que un alimento corrector se proporcione. La costumbre ha consagrado el término y no parece indispensable cambiarlo, y en caso de hacerlo corresponde a un lingüista encontrar el apropiado. Digamos así que el término Desayuno. Escolar es utilizado, en este artículo, como alimento proporcionado en la escuela y destinado a corregir deficiencias del régimen alimenticio habitual de los niños.

Si ha sido necesario establecer en el pais una Instrucción Primaria obligatoria, es porque una parte importante de los jefes de hogar no han tenido el interés o la cultura necesarios para hacer seguir a sus hijos estudios primarios. No habiendo una tendencia espontánea a la desaparición del analfabetismo, no se encontró otra vía para obtenerla, que hacer la instrucción obligatoria y poner la escuela al alcance de toda la población. Una disposición legal de este orden, que significa un gravamen superior a $\$ 150.000,000$ al año para la Caja Fiscal, se ha considerado ampliamente justificada, porque es una manera para mejorar nuestro índice de cultura.

Evidentemente, la elección del porcentaje de analfabetos como índice de cultura es arbitraria y justificada por el grado de precisión con que puede obtenerse el dato. Podría, es claro, utilizarse también otros elementos de la cultura, como datos índices. 
¿No serian, en efecto, excelentes termómetros del grado de cultura de un pais - para no indicar sino algunos- los indices de morbilidad y mortalidad y, entre los primeros, el estado de salud de los niños de edad escolar? Aparece evidente que sí, especialmente si se piensa que en la edad del crecimiento se adquieren las estructuras orgánicas definitivas del individuo, de manera que en el estado de salud del niño se traduce con gran fidelidad el estado de salud de la población, indice evidente del grado de cultura de un pueblo.

En nuestro pais, en que entre los escolares son extraordinariamente frecuentes las deficiencias del desarrollo estatural y ponderal, los trastornos del desarrollo esquelético, las caries dentarias y la susceptibilidad, para adquirir enfermedades infecto-contagiosas, resulta del todo justificable la realización de una acción tendiente a impedir que estos trastornos se produzcan y nos parece evidente que es a ese objeto a que debe estar destinada la parte física de la educación que dispone, como ya hemos dicho, de dos elementos fundamentales: la alimentación y el ejercicio físico. Nos preocupa in esta oportunidad el primer aspecto: la alimentación.

Así como el ejercicio físico, realizado sólo durante algunas horas del día, está destinado a obtener el desarrollo armónico de la musculatura, haciendo trabajar especialmente aquellos grupos que en los movimientos del niño en su vida normal no trabajan, y cuya falta de desarrollo determina una desarmonía en la evolución corporal, así también el desayuno escolar debe estar destinado a proporcionar al organismo aquellos elementos que el niño no recibe o recibe en cantidades insuficientes en la alimentación habitual. Porque es lógico partir de la base que el niño se alimenta así como se mueve: pero que se alimenta mal, así como se mueve mal.

De la misma manera que el educador físico debe estudiar los grupos musculares que requieren ser sometidos a ejercicio y cometería una torpeza si durante su hora de gimnasia se dedicara a hacer trabajar precisamente aquellos grupos musculares que el niño tiene desarrollados por su movimiento habitual, descuidando el ejercicio de los que no trabajan en condiciones ordinarias y que determinan así un desarrollo inarmónico; quien se preocupe del régimen alimenticio de los niños debe estudiar qué elementos faltan para hacer su dieta habitual completa y cometerá un error si utiliza el arma de corrección de que dispone, el desayuno escolar, para mantener una dieta incompleta o para acentuar sus defectos. 


\section{¿EN QUE DEBE CONSISTIR UN DESAYUNO ESCOLAR?}

Preguntarse, entonces, ¿en qué debe consistir un desayuno escolar?, es sinónimo de averiguar qué defectos tiene el régimen alimenticio habitual y qué manera hay de corregirlos.

Es sabido que los trastornos del desarrollo esquelético y las caries dentarias tienen por origen un defecto del metabolismo fósforo-cálcico producido por un aporte insuficiente o desequilibrado de estas sales y de vitamina $\mathrm{D}$.

Los defectos del crecimiento ponderal y la escasa resistencia contra enfermedades infecciosas, reconocen como causa fundamental un aporte insuficiente de determinados aminoácidos, o sea un valor biológico bajo de los prótidos de la dieta, al mismo tiempo que una carencia relativa de vitamina $A$, de complejo vitamínico $B$ y tal vez de vitamina $C$.

El análisis del régimen alimenticio comúnmente seguido por nuestros niños de clases populares demuestra que esos defectos alimenticios están ligados a una carencia relativa o absoluta de leche.

En efecto, la leche, como es sabido, contiene el fósforo y el calcio en cantidades, proporción y estado quimico apropiados para su máximo aprovechamiento; sus proteinas son de la mejor calidad, es decir, constituyen un aporte de todos los aminoácidos, y contiene la vitamina $A$ y el complejo vitamínico $B$ en cantidades importantes, así como la vitamina C, cuando no ha sido sometida a una ebullición prolongada.

Puede afirmarse, sin temor de incurrir en error, que si el régimen de nuestros niños incluyera medio litro de leche al día, dejaría de ser un régimen insuficiente y desaparecerían seguramente los trastornos que hemos mencionado como tan frecuentes. Esta afirmación vale también para los niños de hogares de condiciones más miserables, que viven de lo que reciben como donación, porque siempre los alimentos que asi reciben son alimentos energéticos, sin valor protector y sólo muy excepcionalmente incluyen la leche.

Un desayuno escolar, pues, que pretenda resolver las carencias alimenticias que el niño tiene en su alimentación habitual, o sea obtener que su régimen alimenticio se acerque lo más posible al perfecto para obtener un desarrollo normal, debe estar constituído por leche en una cantidad vecina de $1 / 2$ litro por niño y día. 


\section{¿COMO REALIZAR PRACTICAMENTE EL DESAYUNO?}

El problema tiene caracteres diversos en aquellos sitios en que es obligatoria la pasteurización de la leche y en aquellas en que no lo es. toria.

A.-En sitios en que la pasteurización de la leche es obliga-

Dar de golpe a un niño $1 / 2$ litro de leche sobrepasa la capacidad habitual del estómago de tolerarla y no resulta, pues, conveniente. La solución del problema consiste en dar dos tomas de $250 \mathrm{cc}$. cada vez, una en la mañana al llegar a la escuela, y otra en la tarde al abandonarla, o sea, que cada toma de leche constituya, respectivamente, el desayuno y las once.

Donde hay leche pasteurizada, nada más práctico que proporcionarla en la botella misma, que para ese objeto deberá ser de $250 \mathrm{cc}$., para ser tomada por el niño directamente sin ninguna manipulación previa, por medio de una pajita o un tubo de vidrio esterilizado.

Este método presenta diversas ventajas:

1) Seguridad.-La leche proveniente de una Central de Pasteurización que funciona ajustada a la técnica correcta es una leche segura; pero para que lo sea en el momento de ser tomada es necesario que no haya habido ninguna manipulación entre el momento de cerrar la botella en la Central y el del consumo. Cualquiera manipulación intermedia permite las adulteraciones que van ligadas siempre a una pérdida de valor nutritivo y frecuentemente a contaminaciones por gérmenes patógenos.

2) No existe la necesidad de ningena instalación en la escuela para prepararla ni de utensilios para servirla.

3) Evita el calentamiento posterior a la pasteurización que no hace sino hacerla perder propiedades nutritivas (destrucción de vitaminas, precipitación de fosfatos, etc.)

4) Realiza una enseñanza objetiva sobre la forma en que debe consumirse la leche para obtener todas las ventajas.

Se podrá argüir que la costumbre en el país es tomar la leche azucarada, y con adición de infusión de café o té o polvo de cacao y que, por consiguiente, la forma propuesta contraría esta costumbre. Es necesario considerar a este respecto, que esa costumbre es una mala costumbre que conviene desterrar y que la única manera de conseguirlo es enseñando las buenas costumbres durante la infancia. 

la leche.

B.-En los sitios en que no existe obligación de pasteurizar

En estos sitios el problema es mucho mayor, porque toda la responsabilidad sobre calidad de la leche que en el caso anterior se hace recaer sobre las Centrales de Pasteurización, debe tomarla el Director de la Escuela. cada casc:

Al tomar esta responsabilidad debe estudiar previamente, en

1) Al productor o a los productores que le proporcionen la leche. Debe observar las condiciones en que se realiza la ordeña y asegurarse que se hace con limpieza y buena técnica, que las vacas son sanas y bien alimentadas, y que las condiciones personales del dueño le aseguren que no realizará adulteraciones de la leche.

2) Las condiciones en que se hace el transporte desde el fundo hasta la Escuela.-Debe asegurarse que no dure mucho tiempo, que no se hace a la hora de calor y que el vehículo protege los tarros suficientemente del sol, etc.

Solamente cuando estas etapas de la explotación lechera se hagan en forma perfecta podrá tenerse la seguridad de contar con una leche de calidad suficiente para ser proporcionada sin temor a los niños.

En la Escuela deberá hacerse hervir durante dos minutos y darla inmediatamente a los niños. El ideal es que para cada toma (desayuno y once) se reciba leche recién ordeñada.

En la práctica, asegurarse que las condiciones de recolección y transporte de la leche son buenas, requiere preparación especial que seguramente no tiene cada Director de Escuela, de manera que puede decirse que siempre la leche que no ha sido reconocida y calificada por una Central de Pasteurización, puede ofrecer peligro de adulteración y contaminación.

En aquellas partes en que por las condiciones del clima u otras no puede obtenerse leche pasteurizada ni fresca será necesario usar leche reconstituída, ya sea a partir de leche condensada o de leche en polvo. La reconstitución de la leche debe hacerse en condiciones que no es del caso analizar en este artículo.

\section{¿PUEDE ESTABLECERSE UN DESAYUNO ESCOLAR DESDE LUEGO EN TODO EL PAIS?}

La respuesta es evidentemente negativa. En primer lugar porque toda acción nueva - ya que con respecto al antes denominado 
desayuno escolar ésta es acción nueva- requiere un tiempo de organización y de experiencia para poder ser generalizada.

Por otra parte, la producción de leche del país, que es actualmente baja, no permite de la noche a la mañana entregar la cantidad necesaria para un desayuno generalizado a medio millón de niños.

Su establecimiento debe, pues, ser paulatino y graduado en cada población de acuerdo con las posibilidades de producción de la región lechera que la sirva, de manera que vaya constituyendo simultáneamente un estímulo creciente para la producción local de leche, cuyo aumento beneficiará no sólo a los niños de las escuelas. sino que también a toda la población.

Así como debe ser gradual el establecimiento del desayuno escolar, lo debe ser también el de la pasteurización obligatoria. que hoy día se encuentra en vigencia en 6 ciudades del país y que lógicamente debe ser generalizada. Dada la enorme ventaja que para la seguridad de la leche así como para la facilidad de realización del desayuno tiene proporcionarlo sobre base de leche pasteurizada. la política correcta es, en nuestra opinión. la difusión simultánea de la obligación de pasteurizar con el establecimiento del desayuno escolar, en la forma aquí anunciada.

En la actualidad la población que recibe la leche pasteurizada es vecina de la cuarta parte de la población total del pais, de manera que iniciar el desayuno en esas ciudades. siempre, es claro de una manera paulatina, significará un gran paso en favor de la salud de una parte importante de nuestra población escolar. La generalización al resto del país se haría con el tiempo y siempre marchando de la mano con la pasteurización obligatoria que significa leche segura para los niños y para toda la población.

Imp. "CULTURA".- Argomedo 363 A.-Stgo. 
Aprov. - A. 26-1939 - S. 16/57 (10,000 Ejemplares)

Imp. "CULTURA", Argomedo 363 A.- 5-IX-39. Santiago de Chile 


\section{ESTRUCTURA DEL SERVICIO NACIONAL DE SALUD ${ }^{27}$}

El Boletín del Servicio Nacional de Salud era dirigido en 1955 por el doctor Abraham Horwitz (1910-2000), médico titulado en 1936 cuyo campo de trabajo fueron las enfermedades infecciosas: tuberculosis, sífilis, tifus exantemático, sarampión, entre otras que causaban más de dos tercios de las muertes de niñes y jóvenes. Las relaciones entre el medio ambiente, la vivienda, el agua, la salud de las personas y dichas enfermedades estaba asentada, en dicha época, en numerosas tesis médicas, y era el objetivo del sistema de salud su erradicación y prevención.

Después de una residencia en patología infecciosa y bacteriología en Detroit, Michigan, en 1942 concurrió a realizar estudios de Magíster en Salud Pública en la prestigiosa Universidad de Johns Hopkins de Baltimore, Maryland, título que recibió en 1944. De vuelta a Chile, se propuso organizar la Escuela de Salubridad en la Universidad de Chile con el apoyo de la Fundación Rockefeller. Abraham Horwitz fue, después del profesor Hernán Romero, su segundo director, entre 1945 y 1947.

En 1952, siendo Ministro de Salud Jorge Mardones Restat y durante la presidencia de González Videla, se aprobó la Ley N¹0.383, que dio origen al Servicio Nacional de Salud, organismo encargado de la protección de la salud para toda la población y del fomento y recuperación de la salud de los obreros, esposa e hijos hasta los 15 años. Para su creación se fusionaron la Dirección General de Beneficencia y Asistencia Social; el Servicio Médico de la Caja de Seguro Obrero, el Servicio Nacional de Salubridad, la Dirección General de Protección a la Infancia y a la Adolescencia; la sección técnica de Higiene y Seguridad Industrial de la Dirección General del Trabajo; los servicios médicos y sanitarios de las municipalidades y el Instituto Bacteriológico de Chile.

Fue una reforma de doce años de gestación y en ella participó el doctor Horwitz, quien fue convocado por sus pares y había ganado por concurso de antecedentes el puesto de subdirector normativo. Uno de los hechos interesantes que anota Horwitz en su visión del SNS fue la creación de los médicos generales de zona.

ElBoletín formaba parte sustantiva del sistema, pues proporcionaba información estadística, y su perfeccionamiento permitió medir de manera concreta las tasas de mortalidad infantil debido a un mejor registro generación de políticas necesarias para revertirlas. El texto muestra el giro de las políticas públicas hacia una visión desarrollista y la incidencia del modelo norteamericano en ellas.

27. "Estructura del Servicio Nacional de Salud". Boletín Servicio Nacional de Salud. Santiago, 1 (1):2-5, octubre de 1955. 


\section{SER V ICIO}

NACIONAL

DE SALUD

\section{:}

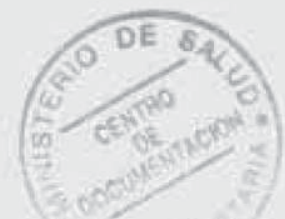

S A N T I A O - C H I L E

OCTUBHE DE I.95 


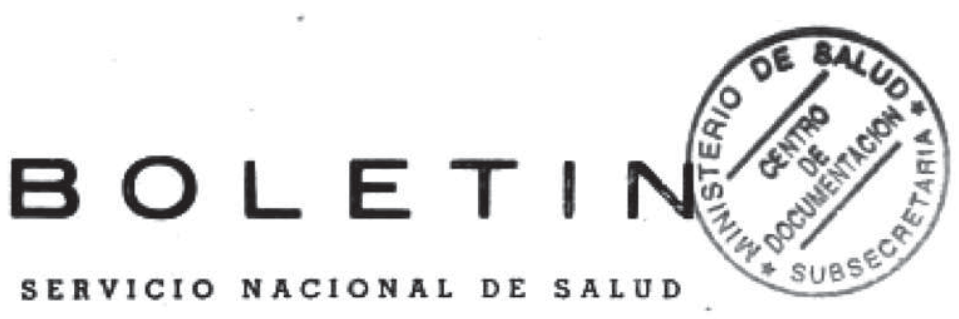

Director: Dr. ABRAHAM HORWITZ

Año I

SAWTIAGO DE CHIL. OCTUBEE DE 1955

$\mathbf{N}^{*} \mathbf{1}$

E D I T O R I L L

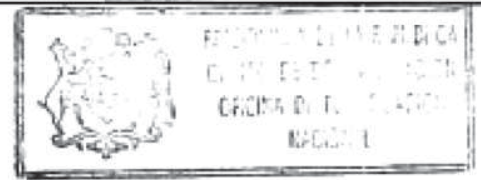

El cumplimiento de los objetivos del Servicio Nacional de Salud exige una permanente unidad de pensamiento y de acción de los funcionarios técnicos con los que tienen responsabilidades exclusivamente administrativas. Todas las acciones que el Servicio debe ejercer de acuerdo con la Ley. se concretan en la aplicación de una norma técnica por medio de un procedimiento administrativo,

La diversidad de tradiciones, de orientación y métodos de trabajo de las Instituciones que se fusionaron. confiere un rasgo de prinera jerarquist a la tarea de establecer esta unidad. Uno de los medios para conseguirla es el conocimiento cabal que cada funcionario debe poseer de los aspectos dominäntes de la vida administrativ'a del Servicio. La información periodica sobre estas materias facilitará la difusión de este conocimiento. Contribuira a poner en präctica la politica de descentralisación ejecutiva que fundamenta la acción del Servicio. Permitirá, por otra parte, la solución de los problemas derivados de la mayor responsabilidad administrativa asignada a los técricos.

La publicación del presente Boletin obedece a dicho propósito. Por su intermedio. la Dirección General pondrá a disposición del personal la información beisica sobre asuntos administrativos de interés general, incluyendo las grandes lineas de su politica en este campo y las normas y disposiciones relacionadas.

Por la trascendencia de los objetivos y acciones del Servicio. el exito de su gestión debe estar condicionado a la superación de antiguas preocupaciones derivadas de viejas rivalidades y saspicacias institucionales, Los remanentes de éstas deben ser substifuidos por un nuevo espiritu institucional que logre la identificación de los funcionarios con los fincs e ideales del Servicio. Se requiere una conciencia colectiua, un nuevo modo de pensar pata poner en práctica igual doctrina en cada una de las acciones y responder a las responsabilidades que tiene la Institución para el progreso del pais. 


\section{ESTRUCTURA DEL SERVICIO NACIONAL DE SALUD .}

\section{T T O D U C I O N}

10.- La Ley No 10.383, de 8 ace Agosto de 195\%, eré el Sorvicio Nacional de Salari mediante in isterración de olmanos de los más importanter of gavizmos medjcos, parativns y preventivos, que exintion en il pais. Como cansecuencin de etto el

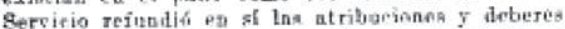
de dichos organismos, esuanados de las leyes y Deeretas Supremon que los regínn, a más de las oblizacinnos que espectfieamente le fijarob ta Lny $y$ su Fieglamento. Recibio tnmbira of patrimonis, recursos a flantas de perkanal de las instituciobes integrantes 5 su presopuesto fuć elevado en in euntin que se estimo indispensuble parn responilur - loz nuevas propíaitos estahlecidos en la Ley.

29- Lns oblizheiones del Serricio Nacional dr Snlud paeden eoscretorse en:

a) Proteccion $₹$ fomesto de ln salud de la pio. blación total del pain:

b) Ateneión mérlica completn $r$ grutuita nl ron. joxto de trabnjndores manusles $y$ a san familias, a Jos grupos de hajo nivel econberico $y$ s un impor tante proporción de au propio personal, lo que re. presenta ed 80 cobjonto aproximainmente of vors de la población. S6lo quedad al marges de eatos bescficios: los empleaços páblicos $y$ purtieulares. las Fuerzas Armades y los obroros dependientos de In Empress de los FF. CC. del Eatado, Marins Mercnnte $y$ otron que tienen orgnnismos propios de previsión y ssistercis. Ademks, los patrones, rem. tistas y otras personns de mitunción económica satisfactoris, bo nfecton a regimenes de Feguridnd. Be exceptén también de sus beneficios los acci. dontadon dol trabaja para evya ntención existe un Berricion sot fonmo.

39. - La orgagiractón del Bervicio, do acoordo con lo establecida en la Ley NP 10.383 contemplo los aiguientes prinejpóos fabdnmontales:

a) Autonomin técnica $y$ administratien.

b) Integración formal y fuscional ile Ins aceioaes y aervicios deatiandos s protecelon, reparación I fomento de la ralud.

e) Centralizacirn on el plantenmiento de la po. Utiles genersl del sorvleio, de sne liness de seción $y$ de las normes pare ln confeeción, ojecución $y$ oraluncían de los programas. d) Degrentratizarifin ejecutiva oben autonomis local en la concepeion 5 realización de los propramas, de penerdo con tis normas aprobalas por ln Dirdectión Getueral.

e) Terarquizncivin de los problemas $y$ orientación de los servieios lacin las mecioneg tofis productivus, realizndes a trasís de jrograman sistemátięar.

f. Relaciós jurraanonte con ln cumunidad orga. nizndo para procuover la activo participación de kata en la solución de sus problemas de salod.

g) Iscrearento de ln eapneidnd técnien $f$ administrativa del peraonal.

\section{E 8 TR प C T U A}

Ln Ley No 10.383 eré loa nireles superiotes del Servicio, Dỉnoceión Goneral y Consejo Nacional, y dotermin 6 in division del puin on Zonns de Snlud. E] Reglnmento completó ans linesa estrueturales egtobleciendo las Sob-Direcciones, General y Norma. tiva, los Departamentos Téczicos y Administrativor, el Cossojo Técnico y, eomo integrantes do In Zonne, los Centros de Salud $y$ los Servicios Espe. cializndos.

\section{1.- DIRECCION GBNERAI}

EA Director Genersl tiene a su cargo, de acuerdo con el Art. 69 de ln Ley, la direecion superior del Servicio. Para njereor in enenta con la totalidad do las atribaclones $\mathrm{y}$ obligaciones que tenian las Directores de lns Instituciones fusionsdas (Art. 72). La corresponde también proponer al Consojo Na. ciosal tollos squallos asuntos que son do su resolu. ción. Por filtimo represente jualicial y extra judicinlmente nl Bervicio, designa peraonal $y$ delogn deterninadns atribneiones, de neuerdo $n$ la Ley $y$ al Entatuto Adeninistrativo.

\section{2- CONBEJO mactonat}

Presidido por el Ministro do Salud Póblica y Previsión Socisl, está integralo por el Director Go neral de salud $y$ por representantes de lns dog ra. mas del Congresto Nacional, de la Pneultad do Me. dieins de la Universidad de Chile, det Consejo Ge. naral del Colegio Médieo, de las Asociacionen pntronnlea y obreras, del Servicio de Bcguro Bocinal $y$ de la Superiatendebeio de Provialón Soeis. 
Correspoade al Consejo Nacional, a propuena del Director General, uar su nprobación a lou jurc. supuestos y plantas del Bervicio $y$ a sus modifica. ciones; denignar $y$ renover ol persosal de mus alto jernfeín; aprobar los Reglamentos internos: su. pervigilar el manejo do los fondos; celebrar coa. tratos de prestacioaps de servicios y controlar fow otros organismos, eatatales $y$ particulares, qioe des. arrollan netividaites relucionadas eon la xalud.

\section{3.- SUB-DIRECOION GENERAL}

Tiene como funeión primordial, de acuerito eon

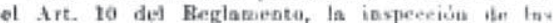
Zonas de Salud. Dehe nues, mantener lat relarienes entre th Direcrión ifol Serviein y low orgunieneng ejeeutivos, y vigilur las anciones y ateneiones ordensudas por la lov, a tracés de las Jefaturns Zonn.

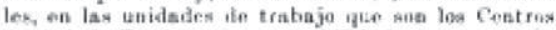
de salud. Fo de wi responsabilidud, como eomple-

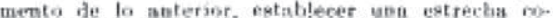
rrelarión de lns actividades de los Departamentes Administrativos en las distintas eaferns de aeciob.

\section{4.- SUB-DIRECCION NORMATIVA}

Ln Sul-Direfeción Normativn tiene funilumentalmeate a su eargo of cytudio de los problemas de sahud del pais $y$ de las scciones tendientes a solucionarlas Debe, por lo tanto, elaborar log programas geaerales del Servicio y las sormas de acción; asesorur a los organismos ejecutivos es Is eorrectr apliención de las normas $y$ en el desarfodlo de los programas, $y$, por b́ltimo estublecet un risteas de medicín de rendimientos, que permita obtener períb́licamente in información indis. pensuble pnra un correcto eoutrol de las acciones.

\section{5. - CONSENO TEONICO}

Está presidido por el Director Gederal e integrailo por las Sub-Directores, tos Jefes te Departamentos Técaicos y los Jefes de sub-Departamentos y Secciones Técnicas que determine el Director General (Art. 25 del Feglamento). Bi Consejo Téçico, como su nambre lo indien, está encargrado de estudiar la politien y las linean de aceión del Bervicio. Espeeislmento dehe dar su opinión al Director Genersl, sobre los Reglanestos $y$ sobre la normalización de las funciones del Servicio y los programns y pressapuestos de los Departamentox Técniess y de las Zonses de Salud.

\section{6.- DEPARTAMENTOS TECNTOOS}

a) Higieno Ambiental- $\mathrm{E}_{8}$ el eneargado del eatudio $y$ confectión de las-normas de control reJacionadas con ln disminveión de los riesgos de enfermar $y$ de morir, derivados del ambiente natural $y$ de ln convivencia. Lo integras los SubDepartasnentos de:

Ingenieria Sanitaria;

Higiene y Seguridad Industrinl y Medicina del Trabajo;

Insectos y Roedorea;

Viviends; $y$
Proteceion y Coatrol de Alimentor

b) Epdidemiologia.- Se oeapa de-los problemas do falud que afectan a grabdes masas de la población. Eatśs formado por los Hub-Departamea. tos de:

Enfurinedades Transmivibles Agudas $y$ Sanidad Internacional:-

Euferaedades Parssitarias:

Tubsreulogis:

Enfermeladea Ventreas: $y$

Entermmades Crouicas of Akridentes

Existe, ademâr, una Asesoria Ternion de Zoonusis.

c) Protnectón Materno-Infantil ; Fomento de la Balud.- Le correxpodito normaltzar y sapervigihr las actirifades tequienter a la promoción de la oalud $y$, en eonsecentecia, su acción se dirige prineipalmente a la defebra del niîo $y$ a los problemas de la flumestación en el plana ancional.

Tieve los siguientea Sab-Departsmentos:

Proteceion Materna e Intantil;

Alimentariba:

Higienu Mental y Alcoholismo

d) Atención Médica- Tiese bajo su responas. bilidad especifica la norenalizacion de las sceiooes de feparación de ls solud Ello involacra el eatudin de los problemas y al dietado de las normas solıre curación $y$ rehabilitsción del individuo enfermo $\%$ In integración de estas acciones con lna funciones de protección $\Sigma$ foecesto de la sslud.

Lod Bab-Departamentos que lo forman 400 :

Eatudio, planifieación $y$ bahilitacióa de establecimientos:

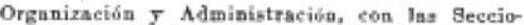
nes: "Mtebehóa Cerrada" 5 "Consultorios Externos"';

Invalidez $y$ Rebobilitació

Beneficios de la Ley No 10.383; 5

Asistencin Socinl Privada.

o) Servicios Tuenicos Generales- En este Departsmento so rebnem las lamadns "funcjones do serviejo" que son actividades genorales y coma: bes a todas las eatrueturns y qoe están fntimamente relacionadas con las acciones de fomerte, protecejón $y$ reparación de la salud.

Está integrado por los siguientes Sub.Departav montos:

Bioestadistica;

Educnción Sanitarin;

Enfermeria;

Bervicio Bacial

Belección $y$ Adiestramiento del Personal; $\subsetneq$

Profexiones Mfdieas.

f) Odontologia_- Son sus funciones especificas el estulio y aormalixación de lns acciones tendientes a ln protección, fomento $z$ reparación de is salud dental, coordiníndolns con las otras acciones de salud. Debe preocuparte ademís del perfeccionamiento técnico del personal $y$ de la investigacióa de las problemas de salud dentnl en el pafs.

En la aetualidad este Departamento consta do don secclosen: "Proteceión $y$ fomento Dental" $y$ "Reparación Dental"". 
ig) Departamento Quimico-Farmsedutico,- Son funeiones del Departainente Quimico-Farmacévtieo el eatudio $y$ adopción de la norinas y procedimien. tos que regulas in atención quimica farancóutica en todos sus appectos y niveles leatro del Bervicio. bo que ineluye el absatecimiento, distribucí́s y con trol te los prodectos quínicos $y$ mediciasles, dro gas, crtupefacieates, conterial saf!tario, artículos do laboratorio, ete. Ademís !n supervigilanein de esta atenciones en lat otros organismos de salud, públi. cas 5 privalas y ell ol comercio libre.

h) Departamento de Iaboratorios- HI Departamesto ato Lahorutorine tiene casno objetixo primordial propender al perfeceiomaniento del raliajo ite Ins Inloratorios del pais. The acuerito con este objo tivo fos sus funciones prineijales las siguienten:

a) Dar norzuas tendientes a regular y uniforman of tratin jo de los lahoratorjos, esute ile diaguón. tico cosao de salud publiea.

b) Proponer su elasifiención y las efeaciunes, $\mathrm{ft}$. siones, nodificneiones y sapresiones the los Lohora. torios existentes.

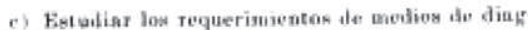
nóstien $x$ thena materisl necesario.

d) Itat normas terniess a los laturaterinod par tieulares y matatales no dependientes del Hervuio que dexnrrolitan aetividades en relación cos la salud publirn 5 supervigilar su cumplimiento.

liatar funciobes se han encargado ul Instituto Pacterioligaro the Chile, el que parn estos efectos depeade de in subdirección Norenntiva.

\section{7.- PUNCION ADMTNISTRATIVA}

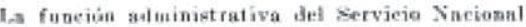
de Salud ba sido edearzada a Depurtamentos, Soecinneg y Ofiejuns que dependen directabiente do ha

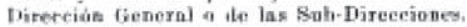

Estí en orraniznción In Secretaria Geueral, ent carzads de correlneionnr todns Ins actividades arleninistratjeas, s objeto de ohtener la meyor eficiencia en sus respectivos campos the heriós $y$ un funcionamiento nraboico en el ruaptimiente de sus taress especificax. En ln actualidal fo organizaciona ndministrativa eompreade las niguirotes eatracturas ba. shers:

\section{- a) Departamento de Fibanass y Presupuestos.-} Depende ite la Dirección General $z$ sus prineipales funcioses pueden sintetizarse en lo sigaiente:

19) Organización téentiea de lax costabilidades;

20) Inuplunisciön te métndos $y$ formularios parn el cerrecto funcionamiente ile ellus:

3o) Inejeceibn silnimistrativa $y$ contable;

so) Casfecrbon de los jresopaentos y revirión furt. matiente de ellos;

b 59) Contripl de top fondas.

Fara el cunplimiento de estas - funciones ne hn a) dudo, n la Otivion in siguiente estraetura:-

c Tosuréria' Alenviral;

Bubdepartamento do Costistilidab.
Sabdepartamento de. Presupuestos; Subilepartamento de Insperción,

b) Departamento Jurialeo,- Tambien depende de la Direceión General y sus principnles funciones ton Las riguientes:

19) Anesorar a la Dirección General y al Conse. jo Nacional eb la eorrecta interpretación de Ias Leyes, Deeretom $x$ Beglamentos qua tienes atingencin con el Servicio: en In aplicación Alel Ratatuto Administrativo 5 iemás leyes que lo rigon $y$ en la confeccion de los reglamentos internos.

bo) Rovisar los stuenrios ndminist rativos;

30) Racurgarse do ln defensa julicial te los intereses del Rervicio; $\mathrm{y}$

40) Fedactar loa actoo y contraton patrimoniales coll otras entidades 0 con particularen, a base de una alecunda información.

Eslax funciones se cumplen n traved de la siguiente eatruetura:

Aecrion Alministrativa

Seceión Judieinl; $\mathrm{y}$

Secribin Biones.

1) Departamento de Arquitectura- Està enear gario del ustadio téenieo $\mathrm{y}$ realiznciún de toilus In. construceignes del Serviuto $x$ de las reparnoiones es las existestes. Tieve además el pontrol del eatada , conservaciôn de los edifieios y tada otra acción in

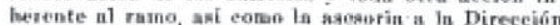
y n] fonsejo en lor problemas do su ineumhencia.

Canstn de des Secriones:

Esturio; $y$

Construeciones.

d) Seceión Registro del Personal, - Tient it st cargo las labores yue ne relneionan en los problemas itel porposal. vnle decir, est purargada de:

a) Canfeccionsin ifirectameste, $D$ agegarar a lase Zonas en la redaceión de loa Deeretos de designa. ciones, truslartos, comisiones, foriados, lieencias, per. misos $\mathrm{y}$ kancionex:

b) Confeccionar los Decretos de recosncimiento de trieains, quinquenios, asignnciones 5 ateor bene fieios Jognles;

c) Llevar las hojas de vida del personal

d) Hecer In tranitacińn de Ins jubilarjones $y$ demis beaeficios do la previnióa:

1) Fxtender certificadna the servicios:

f) Ronlizar el enensillnmiento del perannal; y

g) Efectuar los trúmites eorrespondienter a los cuneursos de ingreto $\boldsymbol{y}$ de sarenan, a las ealificaejones, wite.

Para of eumplimiento de estas futeionea se ba dado la niguiente estructurn:

a) Sub-Bectión Profesionales. Funtionarios <L tey 10.22a) y Funvionurios paramódicos:

b) Persosal administrativo (y'ptólesionales no in. cluides en la Ley 10.283: 
c) Persobal auxiliar $y$ de servieio:

d) Rol del Permonn1:

e) Previgiobn social.

e) Contral de Abagtecimiento.- Tyene por fin lidad ntender el aproviationamiento general de todos to establecimientor que integran ol Servicio, para In ousl adquiere los elementon o mediante importaciones directas o eompras en plazi o elaborn en *

Se lo ha indo la aiguiente estruetara:
it) Servieioa fitaernles:
I) Almaceses;
r) Elaboracién:
d) Proilucriōa

\section{8.- ESTRUCTURA LOCAL}

E] Servicio Nacjonal de Balud cumple con las fuscionen que la Lay lo encomendó, a traves de Ins Zonas de sulud y de los rentros de sialud.

a) Zonas de salud- La división det pais on Zonas olvedece a la necesilind de desecutrulizar la función ditectiva $y$ estat becha de acuerdo con determinnates guográficas $y$ de poblacieis, respetanilo In arganización administrutiva de la Repáblica.

Las Zonas de Sulud tienen ana estruitura hasica que inclaye la asosorin ic expertos ell las funcisuck

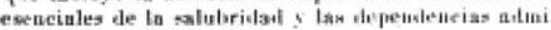
nistratisa: indiapensables.

Las .Tetes do Zonas son usesornilos pur un fonse

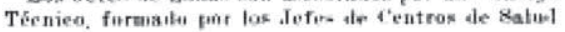

mals importantes de las respectivan jurisdieciones. Además, ge ennsulta la partieiparion de ln comuni dal, a traves de tonsejos Asesnres ile Zona forma. dis por perwonas representativas ite los tiverans grupon y artivialaden rokiunoles.

b) Centros de Balad-fomstitusen ta unifad rje eutiva bifsien del Servicin $F$ patisn encargales itu realixar las arrinnes peadientes a ln promacion. re puravioun y consetvarión de ln snled. Thependen de la Jefatura de Zona correspontiente $y$ seúnen, baju

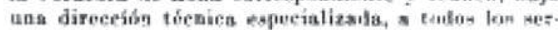
varios axistencisles y de suleri púhlicu, en un distrito a región determinada. Su delimitneión se deterisina de acuerils ran caracterintucas hin-deranera.

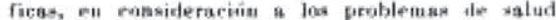
jirevalentes, a las earucteristicus econimiras 5 de

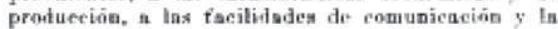

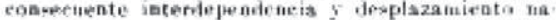
tural ide las personas.

Existen Centros te salud de divergon tifeos, sezún sea la importancin de los problemas de raluil, In tensidal de la pohlacida, los pecorsos de que se disponga y mras caracteriaticay regiongles.

Las accioses del Centro de sialud te realizan on Ins establecimientus bel Sercicio, en los hugares y on lns aitín públicos $y$ privados, como earuelas. locales mociales. esce eb forma de proyectarse a la comunilad en generul.

Las estrueturns, tunto nacionales eomo rtgionales que bemos teseussio, corresponites al espiritu $y=$ los propussitos del Legialaidor $y$ se aulaptau a la eta. fu actanl ale consolidación del Bercicio. Representat una concepeión emiuentemente funcional que responde a los problems hasicas de la Medicina individual $y$ colectivn idel pais $y$ n sus posibilidatses te soltación.

Existe una relación directa entre los fenomenos que condicionan la salud y el bienestar y los que determinan las formas económicas y culturales de vida de las poblaciones. Las condiciones de vida de una población dependen del estadz económico, el que puede medirse por el rolumen de la producción de sus principtles actividades. Una producción baja da origen a salarios insuficientes y éstos determinan a su vez pobreza que se refleja en alimentación deficiente, en hacinamiento, en vivienda no higienica. en incultura. Esta serie de factores son determinantes y coadyuvantes de la enfermedad. la caal. por cso mismo, da lagar a menor energia y capacidad del hombre, con lo que se cierra' el circulo al generarse nuevamente una producción baja. 


\section{A 32 AÑOS DE LA MUERTE DEL PRIMER DIAGNOSTICADO CON VIH: EDMUNDO RODRÍGUEZ, EL INICIO DE UNA HISTORIA $^{28}$}

Este extracto de "Sida en Chile. Historias fragmentadas", de Amelia Donoso y Víctor Hugo Robles, publicado por Fundación Savia y Siempreviva Ediciones, firmado en The Clinic en el año 2016 por Víctor Hugo Robles, es un relato periodístico de la respuesta de la sociedad civil a la pandemia del VIH/Sida en Chile, que apareció en agosto de 1984, en plena dictadura cívico-militar. Su punto de partida es la muerte de Edmundo Rodríguez, profesor homosexual de Maipú, quien falleció a causa del Sida un 22 de agosto de 1984, lo que provocó impacto en la opinión pública. El titular del diario La Tercera dice: "el cáncer gay". La metáfora de la contaminación y el miedo a ella unen al Sida con el largo miedo a las enfermedades infecciosas. Como señaló Susan Sontag, esta nueva enfermedad reactivó los prejuicios morales asociados a las epidemias catastróficas y la puso al lado de las pestes, aunque reforzó su mitología con la imaginería sobre los virus "implacables, insidiosos e infinitamente pacientes” (Sontag, La enfermedad y sus metáforas, 1996, p. 149).

Víctor Hugo Robles (1969) es periodista y activista homosexual, también conocido como "El Che de los gays". En los años noventa integró el Movimiento de Liberación Homosexual, Movilh, y condujo "Triángulo abierto", primer programa radial de homosexuales y lesbianas en Chile transmitido por Radio Tierra. Desde 1996 realiza acciones de impacto público que cruzan las demandas del movimiento homosexual con la instalación y la performance. En abril de 2008 publicó Bandera bueca. Historia del movimiento homosexual de Chile. En 2019 la Radio Universidad de Chile retomó la senda de "Triángulo abierto" con el programa "Siempre viva en vivo", bajo la conducción de Robles, quien indicó que en él

se dará cabida a las voces comúnmente silenciadas por los medios de comunicación tradicionales. Las temáticas de la diversidad sexual, de las personas que vivimos con VIH, son tratadas con un lenguaje estigmatizante y discriminador por esos medios. Lo que hará "Siempre viva en vivo" es darles voz directa a estas personas, para que sean ellas quienes expresen su sentir, vivencias y testimonios ${ }^{29}$.

28. Robles, Víctor Hugo. A 32 años de la muerte del primer diagnosticado con VIH: Edmundo Rodríguez, el inicio de una historia, The Clinic, 2016. Disponible en: https://www.theclinic.cl/2016/08/22/32anos-vih-edmundo-rodriguez/

29. "Llega a Radio y Diario Universidad de Chile el único programa sobre diversidad sexual y VIH”. Diario Uchile, 16 de mayo de 2019. 

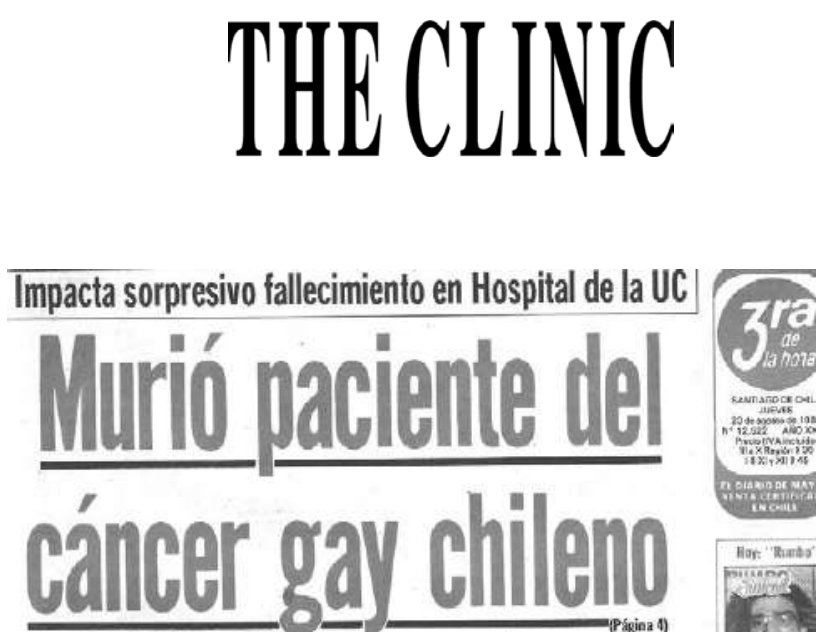

A 32 años de la muerte del primer diagnosticado con VIH:

Edmundo Rodríguez, el inicio de una historia

La situación de salud de Edmundo Rodríguez fue públicamente conocida, por primera vez, a principios de julio de 1984. Mientras, en una antigua casona de Ñuñoa, Salvador Plaza, pareja de Edmundo Rodríguez, lloraba la pérdida de su compañero de vida y encomendaba a un cómplice amigo de parranda la compra sigilosa de los periódicos del 23 de agosto que informaban del triste deceso de su castigado amor. Salvador respiró profundo, recordó las risas y besos compartidos, miró los titulares, leyó las palabras "sodomita", "homosexual" y "muerto de SIDA", pero ninguna de ellas hacía sentido con la inolvidable historia de amor que habían construido con Edmundo. 
“MURIÓ PACIENTE DEL CÁNCER GAY CHILENO”, tituló en portada el diario La Tercera, el jueves 23 de agosto de 1984, abriendo los fuegos de la realidad del SIDA en Chile. Era la sensacionalista e impactante información relativa a la muerte de Edmundo Rodríguez Ramírez, el primer chileno diagnosticado de VIH y muerto a causa del SIDA. "MURIÓ PACIENTE DE LA ENFERMEDAD RARA", dijo por su parte el diario Las Últimas Noticias. "En la madrugada de ayer falleció el primer paciente chileno afectado por el Síndrome de Inmunodeficiencia Adquirida (SIDA), que permanecía internado en el Hospital Clínico de la Universidad Católica. En forma extraoficial se informó que el enfermo, un sodomita de 38 años de edad, había sido dado de alta provisoriamente en los últimos días y que un agravamiento en su estado obligó a sus familiares a reinternarlo en el centro hospitalario", informó el diario La Tercera en páginas interiores. La situación de salud de Edmundo Rodríguez fue públicamente conocida, por primera vez, a principios de julio de 1984, cuando fue presentada por los médicos tratantes, doctores Fernando Figueroa y Guillermo Acuña, en las Primeras Jornadas Médicas del capitalino Hospital Paula Jara Quemada. "Habitualmente, por razones de ética, el Hospital Clínico de la Universidad Católica de Chile resguarda la información referente al diagnóstico, estado y evolución de las enfermedades que afecta a sus pacientes. Los casos clínicos de interés científico son presentados en las tribunas adecuadas para provecho de la comunidad", justificaba el día de la muerte de Edmundo Rodríguez una declaración oficial firmada por el director del Hospital Clínico de la UC, doctor Joaquín Montero Labbé. "La dirección del Hospital Clínico de la Universidad Católica apela a la conciencia ética de los periodistas, que bien saben valorar el secreto profesional y a la comprensión de los medios de difusión en torno a este tipo de problemas", remataba el comunicado de la UC en afán ético. Mientras, en una antigua casona de Ñunoa, Salvador Plaza, pareja de Edmundo Rodríguez, lloraba la pérdida de su compañero de vida y encomendaba a un cómplice amigo de parranda la compra sigilosa de los periódicos del 23 de agosto que informaban del triste deceso de su castigado amor. Salvador respiró profundo, recordó las risas y besos compartidos, miró los titulares, leyó las palabras "sodomita", "homosexual" y "muerto de SIDA", pero ninguna de ellas hacía sentido con la inolvidable historia de amor que habían construido con Edmundo. Una historia de amor y complicidad que impulsó a Salvador a recorrer decididamente el sinuoso camino de la aceptación sexual en años de compleja liberación afectiva. "Yo nací en un tiempo equivocado, nadie sabía de mi sexualidad, lo pasaba pésimo, a veces me visitan 
amigos, pero no se hablaba nunca del tema. Yo provengo de una familia tradicional católica con un padre alcohólico que decía que prefería tener un hijo muerto que un hijo maricón", reconoce Salvador con angustiante e inolvidable dolor infantil. "Yo pensaba que era el único homosexual en el mundo, nací en una época equivocada, entonces mi tranca fue enorme. Afortunadamente, a los 38 años, comencé mi aceptación cuando leí una carta que apareció en el diario El Mercurio, donde un padre relata el penoso suicidio de su hijo homosexual. Esa carta es histórica para mí porque impulsó mi aceptación definitiva. Lo pasé muy mal, pero fui feliz cuando conocí a Edmundo", admite Salvador, relatando emocionado y detenidamente su particular historia de amor. "Tenía una amiga lesbiana de nombre Paulina que me ayudó a conocer a otros amigos. Yo estaba apegado a la Paulina, porque me sentía extraño en el ambiente gay, era un cabro chico con 38 años. Un cabro que tenía mucho miedo. Un día fui al departamento de mi amiga, que vivía con su madre y ahí apareció Edmundo. Estuvimos saliendo como amigos durante dos meses. Edmundo era profesor de castellano, me escribía cartas en letra imprenta sin firmarlas. Él había asumido su sexualidad pero en todo el tiempo que estuvimos juntos, yo nunca conocí su casa, ni él nunca conoció la mía. Me enamoré de Edmundo e incluso compré un departamento en Carlos Antúnez con Marchant Pereira para vernos más tranquilamente", recuerda, agregando: "Era un lugar magnífico, nuestro espacio de encuentro. Un día fuimos a Horcón como amigos y pasó lo que tenía que pasar. Edmundo me dijo que no porque había pasado eso íbamos a ser pareja, rayando así la cancha, pero a los dos meses me trajo una planta enorme de regalo en un taxi desde Maipú, demostrándome así su amor. Ya no se habló más del tema y poco a poco se comenzaron a dar las cosas. Después todo era obvio, no había que hablar mucho, estábamos enamorados". Salvador evoca cada momento de su relación con Edmundo, particularmente los días en que su pareja estuvo internada en el Hospital Clínico de la Universidad Católica, transformándose en el "conejillo de indias" de médicos, enfermeras y periodistas. "Para ustedes, el que yo pueda tener VIH o SIDA es importante porque lo van a publicar, pero cuídense, porque mi madre se operó del corazón y si dan la noticia, se la van a llevar a ella, a mí y también a mi pareja que es bipolar", fue la advertencia que habría realizado Edmundo Rodríguez al cuerpo médico de la UC, según rememora Salvador Plaza. "Recuerdo que cuando Edmundo enfermó, yo era casi la única persona que podía entrar para hablar con él. Me decía que el médico le había dicho, antes de los exámenes de confirmación, que él podía tener AIDS. Yo le reclamé al médico, porque no 
podía decirle eso. Edmundo tenía síntomas de Sarcoma de Kaposi y eso lo complicaba mucho, particularmente las manchas en la cara. Se ponía brisquei para taparlas. Yo creo que Edmundo se contagió con un brasilero que conoció en el centro de Santiago. En ese tiempo se hablaba del SIDA, pero nadie se preocupaba, no se usaban medidas de prevención, pese a todo yo nunca me contagié", señala Salvador. Gustavo Hermosilla, activista del VIH/SIDA y conocido de Edmundo Rodríguez en los inicios de lo que sería posteriormente la Corporación Chilena de Prevención del SIDA, recuerda su figura y asumida sexualidad. "Edmundo era muy simpático, conchudo, alegre. Tenía una vida asumida, amaba a su pareja y se juntaban en el mismo círculo que me reunía yo. Íbamos a los mismos lugares de encuentro homosexual, al Clavel, al Delfín, al Bokara", rememora Gustavo. "Recuerdo que yo fui a ver a Edmundo al Hospital de la Católica pero estaba aislado. Mucho antes me había encontrado con él en el centro y me dijo que se iba a morir, pero yo le respondía que no le creía. Me decía que se quería comprar cosas lindas, porque se iba a morir. Lo acompañé muchas veces antes que entrara a la UC. Al hospital fuimos varios a verlo y algo me decía que no pasaba nada si lo besaba. Lo saludé y estuvimos conversando poco tiempo antes de que falleciera", recuerda hoy con tristeza Gustavo Hermosilla. El decreto de Pinochet El primer antecedente en la legislación chilena en materias de normas relacionadas con enfermedades de transmisión sexual es el Decreto Supremo No 362, del 28 de septiembre de 1983, que trata sobre el reglamento de ETS (Enfermedades de Transmisión Sexual) y cuyo artículo $\mathrm{N}^{\circ} 2$ define que "son enfermedades de transmisión sexual para los efectos del siguiente reglamento, la sífilis, la gonorrea, el linfogranuloma venéreo, el chancro blando y la uretritis nogonocócica”. Un año después, el 10 de septiembre de 1984, se promulga el Decreto N²94, que modifica el No 362 que es el que aprueba el Reglamento sobre Enfermedades de Transmisión Sexual, y que incorpora al Art. $\mathrm{N}^{\circ} 2$, a continuación de la expresión "el linfogranuloma venéreo", la siguiente frase "el síndrome de inmunodeficiencia adquirida (SIDA)". Desde ese minuto el SIDA era asumido como enfermedad en el sistema de salud pública. La modificación de septiembre del año 1984 coincide con la muerte a causa del VIH/SIDA, un mes antes, del primer paciente en el Hospital Clínico de la Universidad Católica, el primer caso conocido públicamente en Chile. La primera "notificación oficial" Presentado en las Primeras Jornadas Médicas del Hospital Paula Jara Quemada, en Santiago, la situación de salud de Edmundo Rodríguez era desconocida e intrigante para los profesionales locales, aunque públicamente la autoridad sanitaria declaraba 
que la "inmunodeficiencia estaba bajo control" en nuestro país. "Esto es un caso aislado, somos un país decente, eso no va a llegar aquî", decía el Ministro de Salud de la época, asegura haber escuchado Gustavo Hermosilla de la boca de las autoridades sanitarias. Desde antes de 1983, las ETS, Enfermedades de Transmisión Sexual, eran controladas en el sistema público de Salud en Chile y a partir de 1984 se incorpora al sistema de salud el denominado: Síndrome de Inmunodeficiencia Adquirida, SIDA. "Existen en Chile los medios y elementos para efectuar el diagnóstico de esta patología. La autoridad sanitaria ha abordado el hecho en forma conjunta con los médicos tratantes del paciente", establecía un comunicado público emitido por la autoridad sanitaria competente. El Ministro de Salud de la época, doctor Winston Chinchón, informaba a la prensa que su cartera había constituido una comisión especial integrada por diversos profesionales, particularmente aquellos dedicados a las llamadas "enfermedades de transmisión sexual”. Respecto del SIDA y puntualmente de Edmundo Rodríguez, cuya identidad no había sido revelada por completo por la prensa, se hablaba del paciente "Edmundo R.R.", Chinchón reconoció que "se desconoce mucho sobre esta enfermedad, pero en ningún caso es un problema de salud pública", decía. Así, entre la desinformación generalizada y la desidia de las autoridades cívico militares de la época, aislado en una sala de un hospital privado de Santiago y mientras la Iglesia Católica ocupaba sendos espacios en la prensa local rechazando categóricamente las bulladas apariciones de la Virgen en Villa Alemana, Edmundo Rodríguez reconocía ser la primera persona viviendo con VIH/SIDA en Chile, sometiéndose a diversos exámenes, sumado a las "notificaciones oficiales" de su "desconocida" y "extraña" enfermedad, batiéndose día tras día entre la vida y la muerte. Según los informes médicos publicados extraoficialmente por la prensa, Edmundo Rodríguez inició las manifestaciones de su enfermedad un año antes de su hospitalización. Se señalaba que presentaba diarrea alta y desarrollaba una mala absorción con lesiones cutáneas que aparecían concomitantes con la diarrea. Estas lesiones eran caracterizadas por placas pardas-violáceas levantadas e indoloras que se localizaban fundamentalmente en la cara, tronco y brazos. Meses antes de su ingreso a la UC, desarrolló una fiebre intermitente que llegó hasta 39,5 grados y un compromiso severo del estado general con una baja de 15 kilos de peso. Posteriormente aparecería una capa violácea en el paladar duro, otra en el ojo y en el espacio rectal. Las pericias médicas registran que se le practicaron diversos exámenes, pero Edmundo, "el paciente" para el equipo médico, seguía evolucionando con fiebre persistente, diarrea frecuente y de volumen variable, 
llegando hasta 1800 c/c, razón por la cual se dispuso de alimentación por sondas. Al día 23 de su hospitalización, presentaba linfoadenopatías generalizadas, es decir, nodulaciones en secciones inguinales, cervicales y axilares. Finalmente, luego de variados exámenes de la más diversa índole, "se llegó al diagnóstico que el enfermo presentaba un defecto de inmunidad celular, con enfermedades oportunistas de tipo viral, micótico y parasitario y de desarrollo de Sarcoma de Kaposi cutáneo y de mucosa periganglionar". Expertos norteamericanos invitados a las Primeras Jornadas Médicas del Hospital Paula Jara Quemada, doctores Donald Louria y Purnendu Sen, pertenecientes a la Facultad de Medicina de New Jersey, destacaron que los principales factores de riesgo para adquirir elVIH/SIDA son "la homosexualidad, el abuso de drogas y las múltiples transfusiones sanguíneas". Respecto de la denominada "promiscuidad" entre hombres homosexuales, Donald Louria, señaló que "se han hecho estudios prospectivos a partir de un caso índice para ver cuántos se infectan. Estos estudios están actualmente en marcha, pero no se sabe hasta el momento cuáles son los resultados. Sin embargo, a pesar de que la promiscuidad se ha demostrado como importante, hemos visto que en casos que han llevado una homosexualidad monogámica por un período de 30 años, no se ha suscitado ningún síndrome", reconocía el experto. La peste rosa $\mathrm{La}$ desinformación general y una vida sexual activa entre homosexuales jóvenes sin prevención provocaron un aumento en el número de personas VIH positivas en Chile. "En los años ochenta había llegado la noticia desde EE.UU., pero era algo que la gente no pescaba mucho", dice Gustavo Hermosilla, agregando: "Los gays veían el SIDA como lejano, importado, por lo demás, no conocían a nadie. En esos años no se usaban condones. El condón no estaba presente en la vida sexual. La sexualidad era absolutamente libre y compulsiva. Existían muchos parques en Santiago, siendo el más visitado el parque Forestal. Recuerdo que cuando se construyó el Metro de Santiago por Providencia, era correr y abrazarse", dice Gustavo, lujurioso. "A nivel internacional estábamos recibiendo información de la llamada peste rosa y de que estaba muriendo gente en Brasil, EE.UU., Europa, entonces ahí como que se frenó el sexo, pero se frenó hasta cierto punto porque seguían existiendo los lugares donde se tenía sexo sin protección, a diestra y siniestra, como los saunas Catedral, Ñuñoa y Matte Pérez. El condón no se usaba, particularmente con el cafiche, a ellos les costaba excitarse con las locas, entonces, la loca no se atrevía a meterle un condón porque al cafiche se le iba a bajar el pico y ella no iba a perder la plata. Los cafiches estaban en otra, además que ellos creían que los homosexuales tenían 
otro gen biológico, entonces, como se decía que el SIDA solo atacaba a homosexuales, ellos como no eran homosexuales, no los iba a atacar. Ahora es para la risa, pero eso creían ellos", relata con antológica picardía Jorge Pavetti, testigo y protagonista de aquellos agitados años. "La homosexualidad se vivía más clandestinamente. Su expresión social se reducía a espacios privados protegidos, en casas de amigos o bien a lugares públicos puntuales que cumplían la función de guetos, discos, algunos pocos bares. Era casi imposible pensar en demostraciones de afecto en público", recuerda Víctor Parra, activista del VIH/ SIDA e integrante histórico de la Corporación Chilena de Prevención del SIDA en los años ochenta. "Edmundo asumía lo que tenía pero pidió que su familia no lo supiese y yo respeté esa decisión", afirma Salvador, agregando: "Cuando Edmundo falleció, yo no fui al funeral. Su familia no supo nunca nada de mí. El día que Edmundo murió, el 22 de agosto de 1984, su casa en Maipú estuvo rodeada de la televisión, la familia no podía salir ni a comprar, porque la televisión estaba ahí’, denuncia Salvador. Horas antes, después de que los familiares de Edmundo retiraran su cuerpo de la UC, una enorme nube de humo gris salía desde el estacionamiento del Hospital Clínico de la Universidad Católica. El colchón, la ropa y los utensilios usados por el primer muerto a causa del VIH/SIDA en Chile ardían como categórico síntoma del estigma, la desinformación, los prejuicios y la discriminación en nuestro país. "La muerte de Edmundo enciende la alarma, particularmente entre sus amigos. No pasó inadvertido porque salió publicado en los titulares de los diarios, imagínate, era el primer caso, onda llegó la peste rosa a Chile", recuerda Gustavo Hermosilla. "La información que se entregó era apocalíptica, terrible, imagínate cómo quedamos nosotros después de leer esos titulares, le prometíamos a todo el mundo que el poto no lo pasábamos nunca más. Nosotros pensábamos eso, pero el poto no", señala risueño Jorge Pavetti. "Para mí, Edmundo significó todo, sufrí demasiado y me cuestioné mucho, porque me asumí a los 38 y a los 42 estaba destruido. Tuve tres años para disfrutarlo, fue un amor compartido. Hasta el día de hoy la familia de Edmundo no ha asumido su historia", confidencia Salvador Plaza. "Edmundo quería que tiraran sus cenizas en el sur. Un día recuerdo que llamé a su casa y era el mismo día en que viajaban al sur para esparcir sus cenizas en el lugar indicado. El padre de Edmundo era retrógrado y no sacaba a la madre ni para los temblores, entonces, sospecho que Edmundo usó su muerte e inventó el viaje de sus cenizas al sur para sacar a su madre de último paseo", señala Salvador con dulzura, cerrando así un emocionante relato sobre la historia de amor con Edmundo Rodríguez Ramírez, una historia que guardó en estricto secreto durante más de 30 años, hasta hoy. 
* Extracto de "Sida en Chile. Historias Fragmentadas" de Amelia Donoso y Víctor Hugo Robles, publicado por Fundación Savia y Siempreviva Ediciones. Relato periodístico de la respuesta de la sociedad civil a la pandemia del VIH/ SIDA en Chile aparecida en agosto de 1984 en plena dictadura cívico - militar. "Sida en Chile, historias fragmentadas", tiene como punto de partida la muerte de Edmundo Rodríguez, profesor homosexual de Maipú, quien falleció a causa del SIDA un 22 de agosto de 1984 provocando impacto en la opinión pública. La historia reconstruye los primeros pasos de las organizaciones comunitarias que emergieron como respuestas a la pandemia destacando el trabajo pionero de la Corporación Chilena de Prevención del SIDA, el Centro de Apoyo a Personas Viviendo con VIH/SIDA y la Coordinadora Nacional de Personas Viviendo con VIH/SIDA VIVOPOSITIVO. Sus protagonistas relatan el devenir político de comunidades nacidas para enfrentar la muerte, la discriminación y el estigma social. 


\section{DECRETO CON FUERZA DE LEY 3/1981. FIJA NORMAS \\ PARA EL OTORGAMIENTO DE PRESTACIONES Y \\ BENEFICIOS DE SALUD POR INSTITUCIONES DE SALUD \\ PREVISIONAL ${ }^{30}$}

En la actual pandemia, las Isapres debieron ser obligadas a activar de manera automática la cobertura para hospitalizados por Covid-19 en julio de 2020, a cinco meses de haber sido declarada la catástrofe nacional, lo que implicaba que dicha enfermedad debía calificar como catastrófica.

El 27 de abril de 1981 se dictó el Decreto con Fuerza de Ley N³, que creó el sistema privado de salud que dio origen a las Instituciones de Salud Previsional (Isapres). Con este decreto, el sector privado pudo acceder, durante la dictadura cívico-militar, a la gestión y prestación de servicios de salud, lo que convirtió a las Isapres en las entidades calificadas para captar las cotizaciones de los contribuyentes. El discurso instalado por la fuerza fue que los privados podrían garantizar de mejor modo la salud, por medio de servicios y prestaciones generados por nuevas instituciones, diferentes al sistema público que, por esa característica, lo público, sería deficiente. Hoy, junto con las AFP, provocan el malestar ciudadano que demanda un cambio que se puede rastrear históricamente en los reclamos realizados ante la Superintendencia de Salud y las Cortes de Apelaciones por las constantes alzas a los precios de los planes de salud, la discriminación por género, por riesgo o por preexistencias. Como puede leerse en el decreto, el punto que se regula es un contrato entre privados que captura al cotizante de manera unilateral. La salud pasa a ser el punto menor de la tabla, y el primero, la regulación financiera.

30. Chile. Decreto con Fuerza de Ley 3/1981, de 19 de mayo, Fija normas para el otorgamiento de prestaciones y beneficios de salud, por instituciones de salud previsional. Ministerio de Salud, 1981. Disponible en: https:/ / www.leychile.cl/Navegar?idNorma $=3570$ 


\section{Biblioteca del Congreso Nacional de Chile Legislación chilena}

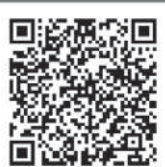

$\begin{array}{ll}\text { Tipo Norma } & \text { : Decreto con Fuerza de Ley } 3 \\ \text { Fecha Publicación } & : 19-05-1981 \\ \text { Fecha Promulgación } & : 27-04-1981 \\ & : \text { MINISTERIO DE SALUD } \\ \text { Organismo } & : \text { FIJA NORMAS PARA EL OTORGAMIENTO DE PRESTACIONES } \\ \text { Título } & \text { BENEFICIOS DE SALUD, POR INSTITUCIONES DE SALUD P } \\ & : \text { Última Versión De : 09-03-1990 } \\ \text { Tipo Versión } & : 09-03-1990 \\ \text { Inicio Vigencia } & : 09-03-1990 \\ \text { Derogación } & : 3570 \\ \text { Id Norma } & : 09-M A R-1990 \\ \text { Texto derogado } & : \text { https://www. leychile.cl/N? } i=3570 \& \mathrm{f}=1990-03-09 \& \mathrm{p}= \\ \text { URL } & \end{array}$

FIJA NORMAS PARA EL OTORGAMIENTO DE PRESTACIONES Y BENEFICIOS DE SALUD, POR INSTITUCIONES DE SALUD NOTA PREVISIONAL Santiago,

que sigue: 27 de Abril de 1981.- Hoy se decretó

D.F.L. N $\mathrm{N}^{\circ}$ - Visto: La facultad que me otorga el inciso final del artículo 84 del decreto ley $\mathrm{N}^{\circ} 3.500$ de 1980 , modificado por el decreto

Decreto con fuerza de ley:

NOTA:

El Art. 53 de la LEY 18933, publicada el

09.03 .1990 , derogó la presente norma a contar de la fecha dé vigencia de su Título II, la que es, de conformidad con su Art. 52, desde que se

publique el decreto con fuerza de ley que fije la planta y la dotación máxima de personal de la superintendencia. Dicha norma es el DFL 35 , Salud, publicado el 01.09.1990.

TITULO I

Normas Generales

Artículo $1^{\circ}$.- Las instituciones o entidades a que hace referencia el inciso $3^{\circ}$ del articulo $84^{\circ}$ del decreto ley $\mathrm{N}^{\circ} 3.500$ de 1980 , se denominarán, para el solo efecto de esta ley, "Instituciones de Salud Previsional", serán personas jurídicas regidas por las disposiciones legales o reglamentarias que les sean propias de acuerdo a su esta ley establece. Dichas instituciones sustituiran en el otorgamiento de las prestaciones y beneficios de salud a los Servicios de Salud $y$ al Fondo Nacional de Salud, sin perjuicio de lo dispuesto en los articulos $14^{\circ} \mathrm{y} 15^{\circ}$ de esta ley.

Estas instituciones serán fiscalizadas por el Fondo Nacional de Salud de acuerdo con las facultades que expresamente se le otorgan en el presente cuerpolegal, sin perjuicio de la fiscalizacion a que estan sujetas de

Artículo $2^{\circ}$.- Para los fines de esta ley se entenderá:

a) Las expresiones "Servicio" o "Fondo", por Fondo Nacional de salud. 


\section{Biblioteca del Congreso Nacional de Chile Legislación chilena}

b) La expresión "Institución" por Institución de Salud Previsional.

c) La expresión "Capital", por el capital mínimo establecido en el articulo $6^{\circ}$ de esta ley.

d) La expresión "Garantia", por la garantia

establecida en el artículo $7^{\circ}$ de esta ley.

e) La expresión "Administradora", por Administradora de Fondos de Pensiones.

f) Las expresiones "Cargas" y "Grupo Familiar", por las personas a que hace referencia el articulo $20^{\circ}$ de éta
ley.

g) La expresión "Registro", corresponde a la inscripción de una persona jurídica en el Fondo Nacional de Salud para poder operar como Institución de Salud Previsional.

h) La expresión "Cotización para Salud", corresponde a la cotización establecida en los articulos $84^{\circ}$ y $92^{\circ}$ del

TITULO II

De las Instituciones

Articulo $3^{\circ}$ - Las Instituciones deberán contemplar en su objeto social el otorgamiento de prestaciones y beneficios de salud, ya sea directamente o a travess del financiamiento de las mismas.

Las Instituciones no podrán, para el otorgamiento de los beneficios pactados, celebrar convenios con los Servicios de Salud creados en el decreto ley $\mathrm{N}^{\circ} 2.763 \mathrm{del}$ año 1979

Los Servicios de salud referidos en el inciso anterior $y$ los organismos adscritos al Sistema Nacional de Servicios de

Salud, no podrán registrarse en el Fondo, como
Instituciones de Salud Previsional.

Artículo $4^{\circ}$ - Las Instituciones, para poder captar la cotización establecida en los artículos $84^{\circ}$ y $92^{\circ}$ del decreto ley $\mathrm{N}^{\circ} 3.500$ de $1980, \mathrm{y}$ operar como tales, deberán cumplir con los requisitos establecidos en esta ley y icitar su registro al Fondo.

El Fondo Nacional de Salud calificará la solicitud de registro, para lo cual la interesada deberá proporcionar todos los antecedentes pertinentes que le fueren requeridos para acreditar su naturaleza juridica y dar cumplimiento a

El Fondo deberá pronunciarse sobre las solicitudes que se presenten en un plazo no superior a 30 días y podrá rechazar las que no cumplan con las exigencias precedentes dentro delar pod dentro del plazo de 30 dias contados desde la fecha de su instancia, siendo su resolución obligatoria para el Fondo.

Artículo $5^{\circ}$ :- Ninguna Entidad podrá arrogarse la registrada en

Tampoco podrá poner en su local u oficina plancha aviso que contenga expresiones que indiquen que se trata de una Institucion de salud previsional, ni podra hacer uso de membretes, carteles, titulos, formularios, recibos, circulares cualquier, the pape que contengan nombre u dedi palus que indiquen que los negocios a que se. dedican dichas personas son los de estas Instituciones. Les prensa u tales expresiones.

Las infracciones a este articulo se castigarán de acuerdo a la normativa vigente. El Fondo tendrá respecto de los presuntos infractores de esta ley, facultades de inspección.

Articulo $6^{\circ}$.- Las Instituciones deberán acreditar y 


\section{Biblioteca del Congreso Nacional de Chile Legislación chilena}

mantener un capital minimo equivalente a 2.000 Unidades de Fomento, que deberá encontrarse enterado en el momento de ser presentada la solicitud de registro al Fondo Nacional de Salud. Para estos efectos se considerarán también los fondos de reserva que tenga constituidos la Entidad.

TITULO III

De la garantía

Artículo $7^{\circ}$.- Para cautelar el cumplimiento de las obligaciones establecidas deberán constituir y mantener en el Fondo Nacional de Salud una garantía equivalente a un mes de cotizaciones percibidas, en la forma y condiciones uniformes y generales que este determine.

para mantener actualizada dicha garantía, la

Institución estará obligada a enterar en el Fondo Nacional de Salud dentro de los 20 primeros días de cada mes la diferencia entre el monto total de las cotizaciones percibidas en el mes anterior, y la garantía mantenida por la Institución, siempre y cuando la diferencia antes mencionada supere el $20 \%$ de esta última.

Cuando el monto de la cotización para un mes

determinado sea inferior al $80 \%$ de la garantía mantenida en dicho mes, la Institución podrá solicitar al Fondo la devolución de la parte de dicha garantía que exceda al monto de la cotización total percibida. El Fondo tendrá el de 20 dias para electuar la devolución a contar del momento en que la Institución haga la respectiva solicitud.

En todo caso la garantía nunca podrá ser inferior a 600 Unidades de Fomento y deberá constituirse al registro de la Institución.

fund Director del Fondo podrá mediante resolución fundada $y$ para su aplicación general rebajar la garantía haciendola equivalente a un porcentaje no inferior al 50 de la estipulada en el inciso porcentajé establecido sobre la cotización percibida en el mes anterior y el monto resultante, se comparará con la garantia existente la que deberá módificarse según la modalidad establecida en los incisos $2^{\circ}$ y $3^{\circ}$ de este artículo.

El minimo de 600 unidades de Fomento para la garantía, también podrá ser rebajado en la misma forma y proporción

La garantía deberá constituirse en dinero efectivo o en los instrumentos señalados en las letras a) y b) del caso el plazo de vencimiento de los instrumentos no podrá ser superior a go dias.

un 10 l Fondo podrá exigir mediante resolución, que hasta un $10 \%$ de la garantia se constituya en dinero efectivo Fomento para los efectos de su reajuste.

Artículo $8^{\circ}$ - El Fondo Nacional de Salud controlará que las Instituciones mantengan el capital mínimo exigido y cumplan con la garantía en las condiciones establecidas on el articulo anterior.

Articulo $9^{\circ}$ - La garantía será inembargable y el Fondo Nacional de Salud podrá hacerla efectiva total o

a) En el evento que la Institución en el caso del

dentro del plazo legal los valónes que por utilizacion del Sistema de Medicina Curativa procedan.

b) Para cubrir los beneficios mínimos establecidos en

el articulo $15^{\circ}$ de esta Ley, cuando la Institución 


\section{Biblioteca del Congreso Nacional de Chile Legislación chilena}

incurra en incumplimiento de lo resuelto por la Comisión de Medicina Preventiva e Invalidez.

c) En los casos de no pago dentro del plazo de las

multas que establece esta Ley.

En el evento que el Fondo haga uso de las atribuciones conferidas en el inciso anterior, la Institución estará obligada a completar la garantía de acuerdo con 10 dispuesto en el artículo $7^{\circ}$ de este cuerpo legal dentro de 10 días contados desde la fecha en que el Fondo le

comunique su resolución de giro. suficiente para la cancelación del registro de la Institución.

TITULO IV

De las cotizaciones

Artículo $10^{\circ}$ - Los trabajadores que opten por aportar su cotización para salud a alguna Institución, deberán suscribir un contrato de acuerdo a lo establecido en los artículos $14^{\circ}$ y siguientes de esta ley.

La Institución deberá comunicar al Fondo, según el procedimiento que éste establezca, la suscripción del contrato a lo menos con un mes de anticipación a la fecha que las partes convengan para que los beneficios pactados se hagan exigibles.

Tratandose de trabajadores dependientes, la

comunicación antes señalada también deberá efectuarse al empleador, a la Caja de Previsión respectiva y a la Administradora de Fondos de Pensiones correspondiente, con igual antelación.

En el caso de trabajadores independientes, la exigencia establecida en el inciso anterior, regirá solo en

relación con la Administradora de Fondos de Pensiones respectiva.

Artículo $11^{\circ}$ - La cotización para salud deberá ser descontada por el empleador y enterada por éste a la Administradora de Fondos de Pensiones a que se encuentre afiliado el cotizante, todo ello sujeto a lo establecido en el articulo 19. del decreto ley numero 3.500 de 1980 , con excepcion de 10 dispuesto en sus incisos sexto $y$ séptimo. penales, en su caso, serán cobrados por la Administradora y puestos a disposición de la Institución. El recargo del decrea decreto ley $N$. 50 de 1980 , será de beneficio de lá Administradora conjuntamente con las costas de cobranza. Las Administradoras deberan seguir las acciones para el cobro de las cotizaciones devengadas segun los incisos anteriores, aun cuando el cotizante se hubiere cambiado de la cotización para salud al Fondo Nacional de Salud.

Articulo $12^{\circ}$.- Recaudados por la Administradora de Fondos de Pensiones la cotización para salud y los intereses y reajustes que correspondieren, ésta los pondrá a disposición de la respectiva Institución, dentro de un plazo no superior a los 5 días.

El incumplimiento por parte de la Administradora de Fondos de pensiones de la obligación preceptuada en el inciso anterior, producirá los efectos establecidos en el inciso quinto del articulo Superintendencia de Administradoras de Fondos de pensiones Superintendencia de Administradoras de Fondos de pensiones Fondo Nacional de salua, el referido incumplimiento.

Las cotizaciones, sus intereses y reajustes, gozarán para su cobro del privilegio

Artículo $13^{\circ}$.- Si los cotizantes convinieren con la 


\section{Biblioteca del Congreso Nacional de Chile}

Institución pagos adicionales a la cotización legal para salud, este aporte convencional no gozará de la exención establecida en los articulos $22^{\circ}$ y $92^{\circ}$ del decreto ley $N^{\circ} 3.500$ de 1980, ni les serán aplicables las disposiciones de esta ley.

\section{TITULO $\mathrm{V}$}

De las prestaciones

Artículo $14^{\circ}$.- Para el otorgamiento de las

prestaciones y beneficios de salud, que regula esta ley, los trabajadores deberán suscribir un contrato con la Institución de Salud previsional que elijan.

En este contrato las partes podrán convenir libremente el otorgamiento, forma, modalidad y condiciones de las prestaciones y beneficios para la recuperación de la salud. En todo caso, cualesquiera fuere lo convenido, el cotizante y las personas señaladas en el artículo $20^{\circ}$ de esta ley, tendrán siempre la opción de atenderse por el Sistema de Medicina Curativa de la ley $\mathrm{N}^{\circ} 16.781$, caso en el cual, la Institución deberá pagar al Fondo la parte

Artículo $15^{\circ}$.- Para los efectos del otorgamiento de los beneficios relacionados con la Medicina Preventiva y regímenes de subsidios, las partes establecerán el sistema tendiente a proporcionarlos. Dichas prestaciones no podrán ser inferiores a las que reciba un beneficiario de la ley número 6.174, ni los subsidios por incapacidad laboral, inferiores a los que correspondan de acuerdo al régimen general de subsidios establecido en el DFL. numero 44 8, del Ministerio del Trabajo y Previsión Social. Comisión de Medicina Preventiva e Invalidez establecida en el artículo $210^{\circ}$ del decreto supremo número 281 de 1980 , del Ministerio de Salud Pública, correspondiente a su domicilio, cuando estime que lo obtenido es inferior a los minimos establecidos en el inciso anterior.

La Comisión de Medicina Preventiva e Invalidez conocerá del reclamo en única instancia y su resolución será obligatoria para las partes. El cumplimiento de ella por parte de la Insticion, debera efectuarse dentro del plazo, condiciones y modalidades que fije la resolución. el cotizante podra solicitar al Fondo que haga efectiva la en el artículo $9^{\circ}$ de esta ley.

Artículo $16^{\circ}$ - Sin perjuicio de 10 establecido en el inciso $1^{\circ}$ del articulo anterior, la Institución deberá descontar de los subsidios que pague el porcentaje que de acuerdo al decreta Iinanciar el Fondo de pensiones del cotizante y las pensiones de invalidez y sobrevivenoia.

Admi Institucion debera enterar estos descuentos en la Administradora respectiva, en los mismos plazos que fija decreto ley $\mathrm{N}^{\circ}$
cotizaciones.

Artículo $17^{\circ}$.- Las certificaciones médicas que sirvieren de antecedente al ejercicio de derechos o. beneficios legales, deberan ser visadas por el Servicio de Salud de la jurisaiccion. de trabajo del cotizante.

formularios que al efecto con Salud.

Artículo $18^{\circ}$.- Los contratos a que hace referencia el artículo $14^{\circ}$ de esta ley, deberán ser pactados por un plazo no inferior a 12 méses y no podrá desahuciarse 


\section{Biblioteca del Congreso Nacional de Chile}

unilateralmente por la Institución durante su vigencia, salvo incumplimiento por parte del cotizante de sus obligaciones contractuales. El cotizante podrá en todo tiempo y con una antelación no inferior a 30 días, desahuciar el contrato para lo cual bastará una comunicación a la Institución con copia al empleador, a la Administradora, Caja de Previsión correspondiente y a Fondo Nacional de Salud, quedando él y sus cargas afectos al régimen general de prestaciones y beneficios de salud que le correspondan en el Fondo. En este caso el empleador deberá remitir la cotización para salud a la Caja de Previsión respectiva mientras el cotizante no opte por una nueva Institución.

Cuando el cotizante haga uso de la facultad establecida en el inciso anterior y una vez cumplidos los requisitos y transcurrido el plazo establecido en él, la termínación surtirá plenos efectos a contar del primer día del mes siguiente a la fecha de término de dicho plazo.

En todo caso los contratos deberán ser siempre pactados por meses calendarios y se entenderá para todos los efectos de esta ley, que los beneficios contemplados para un mes estarán financiados por la cotización devengada en el mes inmediatamente anterior, todo ello independientemente de cuando la Institución perciba efectivamente la cotización. Se entenderá automáticamente prorrogado el contrato, en el evento que al día de su vencimiento el cotizante se encuentre en situación de incapacidad laboral, su vigencia se extenderá por el tiempo que dure la incapacidad y mientras no se declare la invalidez del cotizante; durante este periodo el cotizante no podrá desahuciar el contrato. Las Instituciones podrán en casos calificados solicitar ley $\mathrm{N}^{\circ} 3.500$, de 1980 , la declaración de invalidez del cotizante.

Artículo $19^{\circ}$.- Cuando el cotizante incurra en incumplimiento de las obligaciones contractuales, la Institucion podrá poner termino al contrato comunicando por escrito tal decision al cotizante, caso en el cual los beneficios minimos garantizados en los articulos $14^{\circ} \mathrm{y}$ 15 de esta ley, seguiran siendo cargo de la Institucion hasta el termino del mes siguiente a la fecha de su extincion on caso de que el cotizante se encuentre en dicha situación y
siempre que este plazo sea superior al antes indicado.

Articulo $20^{\circ}$.- Los contratos celebrados entre la Institución y el cotizante deberán considerar como sujeto porgas familiares por las cuales perciba asignación familiar.

Los beneficios del contrato se extenderán por el solo ministerio de la ley a todas las nuevas cargas que declare el cotizante y por las cuales perciba asignacion familiar. quienes

Artículo $21^{\circ}$. La Institución deberá otorgar al cotizante y grupo familiar un documento identificatorio, el cotizante y grupo familiar un documento identificatorio, exigidos al efecto por el Fondo.

Articulo $22^{\circ}$. El Fondo Nacional de Salud podrá vender ordenes de atención del Sistema de Medicina Curativa a los puedan ejercer la opción establecida en el inciso $3^{\circ} \mathrm{del}$ artículo $14^{\circ}$ de esta ley.

Artículo $23^{\circ}$.- Las Comisiones de Medicina Preventiva e Invalidez de los Servicios de Salud deberán resolver los reclamos que los cotizantes miembros de un grupo familiar les presenten, de acuerdo al derecho establecido en el 


\section{Biblioteca del Congreso Nacional de Chile}

inciso $2^{\circ}$ del articulo $15^{\circ}$ de la presente ley.

TITULO VI

De la Fiscalización y Sanciones

Articulo $24^{\circ}$.- Las Instituciones deberán mantener en sus oficinas y para información del público en general un extracto que proporcione los siguientes antecedentes:

1.- Razón social y representantes legales.

2.- Domicilio, agencias y sucursales.

3.- Fecha de su constitución y registro en el Fondo

4.- Capital y duración de la sociedad.

de - Balance general del último ejercicio y los estados de situacion que determine el Fondo.

6.- Monto de la garantía y formato tipo de los

contratos ofrecidos a los trabajadores.

La información referida deberá actualizarse

mensualmente dentro de los primeros 5 días de cada mes.

Copia de la información y actualización deberán ser
remitidas al Fondo.

Artículo $25^{\circ}$ - Sin perjuicio de 10 establecido en el articulo anterior las Instituciones deberán tener

actualizadas ante el Fondo, mes a mes, la información relativa al numero e identificación dé sus cotizantes y grupo familiar y monto de las cotizaciones percibidas; comunicarle las variaciones que de acuerdo a lo dispuesto en esta ley, experimenta la garantía del artículo $7^{\circ}$ y los antecedentes que se han tenido en vista para calcularla; su contabilidad deberá llevarse al día y estar a disposición del Fondo cuando éste asi lo exigiere y finalmente deberán proporcionarle todos los antecedentes $y$ documentacion pertinente que el servicio les requiera en ejercicio de sus facultades de fiscalización.

Artículo $26^{\circ}$ - El incumplimiento por parte de las Instituciones de las obligaciones que les impone esta ley o las instrucciones que imparta el Fondo, será sancionado con multa a benelicio liscal que aplicará el Fondo mediante resolucion fundada $y$ que no podra exceder de 100 Unidades de Fomento. En caso de reiteracion, el Fondo podra

De la multa podrá reclamarse ante la misma autoridad y dentro del plazo, forma y condiciones establecidas en el siguiente.

Artículo $27^{\circ}$.- El Fondo podrá mediante resolución fundada, cancelar el registro de una Institución en cualquiera de los siguientes casos:

a) Cuando su capital disminuya a una cantidad inferior a

b) Por incumplimiento a la obligación establecida en el artículo $7^{\circ}$ de esta ley.

) Por quiebra de la Institución.

obligaciones que emanan de los articulos $14^{\circ} \mathrm{y} 15^{\circ}$ de esta ley.

e) En caso de incumplimiento grave de las disposiciones legales y/o reglamentarias que le son propias de acuerdo a su naturaleza jurídica.

f) Por incumplimiento grave y reiterado de las obligaciones que le impone esta ley.

De la cancelación podrá reclamarse dentro del plazo de 5 días de comunicada, ante el Ministerio de Salud, el cual se pronunciará sobre ella en única instancia y sin forma de juicio en un lapso no superior a 15 día contados desde la fecha de recepción de la reclamación. En contra de la resolución del Ministerio, no procederá recurso alguno.

Artículo $28^{\circ}$.- Dispuesta la cancelación del registro 


\section{Biblioteca del Congreso Nacional de Chile}

de una Institución, el Director del Fondo Nacional de

Salud, podrá ordenar de inmediato y sin esperar que dicha

resolución se encuentre a firme, que las Administradoras de

Fondos de Pensiones que correspondan, suspendan los giros de

las cotizaciones a la Institución aféctada.

En el caso previsto anteriormente, si el reclamo

interpuesto por la Institución fuere ácogido, las

Administradoras de Fondos de pensiones deberán poner a

disposición de ella las cotizaciones a que se refiere el

inciso precedente, dentro del plazo de dos dias contados

desde la fecha de la comunicación que el Fondo les dirija al efecto.

Encontrándose a firme la resolución que cancela el

registro, las Administradoras de Fondos de Pensiones

correspondientes pondrán a disposición del Fondo Nacional

de Salud la cotización para salud y los cotizantes y cargas

continuarán afectos al régimen general de prestaciones y

beneficios que dicho Servicio administra, ello mientras no

se opte nuevamente por otra Institución de Salud
Previsional.

Artículo $29^{\circ}$ - Cancelado el registro, la garantía del articulo $7^{\circ}$, será liquidada dentro de un plazo no

superior a 180 días por el Fondo Nacional de Salud, para el cumplimiento de las obligaciones que a la fecha del cierre de registro tuviere la Institución con el Fondo Nacional de Salud o sus cotizantes y cargas.

El Fondo Nacional de Salud, una vez pagadas las multas que se le adeuden, solucionará las obligaciones referidas en el inciso anterior sólo hasta el monto cubierto por la garantía, debiendo en lo demás los afectados perseguir directamente a la Institución, gozando sus créditos de privilegio de la primera clase, de acuerdo a 10 establecido en el articulo 2.472 del codigo civil, el que se pagara inmediatamente después de los créditos del Fisco y

Para los efectos de la liquidación, se entenderá que la Institución por el solo hecho de su registro faculta al Fondo para incautarse, si lo estimare necesario, de toda la documentación relacionada con la institución $y$ sus cotizantes.

Si practicada la liquidación quedare un remanente en favor de la Institución, el Fondo tendrá el plazo de dos dias para el giro del saldo de la garantía en favor de esa

Artículo $30^{\circ}$.- Cuando una Institución solicite la cancelación de su registro, deberán sus representantes legales presentar en escritura publica una declaración jurada, en la cual se expresaran las causas que motivan la pendicntes la circunstancia de no existir obligaciones pendientes con el Fondo, los cotizantes yus cargas.

todo, el Fondo podrá requerir an

adicionales si 10 estimare pertinente, como también exigir publicaciones

Cumplido lo previsto en los incisos anteriores, el Fondo

cancelará el registro mediante resolución fundada de

Director $y$ tendra un plazo de 90 dias para devolver

esta ley.

Articulo $31^{\circ}$.- La presente ley entrará en vigencia el día primero del mes siguiente a la fecha de su publicación dia primero del mes

Deróganse todas ias normas que fueren contrarias o

incompatibles con su aplicación.

TITULO VII

Disposiciones transitorias

Artículo primero.- Facúltase al Director del Fondo 
Biblioteca del Congreso Nacional de Chile Legislación chilena

Nacional de Salud para que no obstante lo dispuesto en el artículo $4^{\circ}$ de esta ley, califique en forma discrecional eno de 3 años, contados desde la entrada en vigencia de esta ley, la procedencia de los registros que se le soliciten.

Tómese razón, comuníquese, publíquese e insértese

en la Recopilación oficial de la Contraloría General de la República.- AUGUSTO PINOCHET UGARTE, General de Ejército, Presidente de la República.- Hernán Rivera Calderón,

Contralmirante, Ministro de Salud.- Sergio de Castro del Trabajo y Previsión Social. del Trabajo y Previsión Social.

Lo que transcribo a Ud. para su conocimiento.- Saluda a Ud.- Hernán Büchi Buc, subsecretario de salud. 


\section{HISTORIA DE LA LEY N¹9.966. ESTABLECE UN RÉGIMEN DE GARANTÍAS DE SALUD (AUGE). MENSAJE DE S.E. EL PRESIDENTE DE LA REPÚBLICA CON EL QUE SE INICIA UN PROYECTO DE LEY QUE ESTABLECE UN RÉGIMEN DE GARANTÍAS EN SALUD, 22 DE MAYO DE 2002, MENSAJE EN SESIÓN 2, LEGISLATURA $347^{31}$}

El presidente Ricardo Lagos promulgó la llamada Ley Auge N¹9.966 en agosto del año 2004, a dos años del ingreso del proyecto. Se publicó en el Diario Oficial el 3 de septiembre de ese mismo año y se anunció que la población podría acceder efectivamente a la cobertura de 25 patologías. El plan de Garantías Explícitas en Salud (GES) o Auge intentó fortalecer el principio de la salud como un derecho humano fundamental y un bien público en el marco de Constitución de 1980, por lo que aseguraba la cobertura de beneficios garantizados por ley para las personas afiliadas a Fonasa y a las Isapres que habían sido creadas por el Decreto con Fuerza de Ley $\mathrm{N}^{0} 3$ del año 1981. Las garantías exigibles son de acceso (derecho por ley de la prestación de salud), oportunidad (tiempos máximos de espera para el otorgamiento de las prestaciones), protección financiera (la persona beneficiaria cancelará un porcentaje de la afiliación) y calidad (otorgamiento de las prestaciones por un prestador acreditado o certificado. Leyendo en negativo, se puede apreciar la tensión entre una política pública de salud asentada en una institucionalidad de salud igualmente pública como herencia del mundo pre golpe de Estado de 1973 y pre Constitución de 1980, y el neoliberalismo que transformó en prestaciones de servicios el derecho a la salud.

Efectivamente, el Plan Auge se puso en marcha en el año 2005 y a diez años de su implementación, la presidenta Michelle Bachelet, médica de profesión, destacó dos principales logros:

Hemos disminuido la brecha de mortalidad infantil entre los más pobres y los más ricos, entre los distintos quintiles. (Además) se ha bajado la tasa de

31. Biblioteca del Congreso, Historia de la Ley N. 19.966, Establece un régimen de Garantías de Salud. (AUGE). Mensaje de S.E. el Presidente de la República con el que se inicia un proyecto de ley que establece un régimen de garantías en salud, 22 de mayo de 2002, mensaje en Sesión 2, Legislatura 347. Santiago, 2018. Disponible en: https://www.bcn.cl/historiadelaley/fileadmin/file_ley/5682/ HLD_5682_749a0d2dec7072ac83d52ebf0f2ff393.pdf 
mortalidad por enfermedades cardiovasculares como el infarto cardíaco, por ejemplo. O sea, no es solo atención, sino que además se ha permitido que más gente viva y viva en buenas condiciones ${ }^{32}$.

El desafío del Auge está en el fortalecimiento del sistema público de salud, pues a esa fecha el Ministerio de Salud reportaba que el 65 por ciento de las atenciones se resolvieron en el nivel primario de atención (como CES, Cesfam y Sapu), mientras el 35 por ciento restante se ha realizado en hospitales. La disminución de las listas de espera para acceder a la cobertura se transformó en un indicador de gestión y un instrumento político relevante.

Al 2019, existen 85 patologías acogidas a esta ley, la que cubre accidentes graves, enfermedades del corazón y el cerebro, enfermedades crónicas, enfermedades de la visión, intervenciones quirúrgicas, parto, prematurez y enfermedades del recién nacido, salud del adulto mayor de 65 años, salud bucal, salud en personas menores de 15 años, salud mental, tratamiento de cánceres y tratamientos preventivos.

32. "Presidenta conmemora 10 años del Auge, sistema que registra 25 millones de problemas de salud resueltos". En: www.gob.cl, 30 de julio de 2015. 


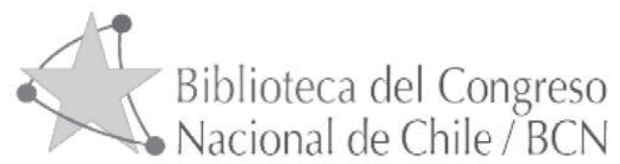

\section{Historia de la Ley $\mathbf{N}^{\circ} \mathbf{1 9 . 9 6 6}$}

Establece un régimen de Garantías de Salud. (AUGE) 
REVISTA ANALES

\section{Nota Explicativa}

Esta Historia de Ley ha sido construida por la Biblioteca del Congreso Nacional a partir de la información disponible en sus archivos.

Se han incluido los distintos documentos de la tramitación legislativa, ordenados conforme su ocurrencia en cada uno de los trámites del proceso de formación de la ley.

Se han omitido documentos de mera o simple tramitación, que no proporcionan información relevante para efectos de la Historia de Ley.

Para efectos de facilitar la revisión de la documentación de este archivo, se incorpora un índice.

Al final del archivo se incorpora el texto de la norma aprobado conforme a la tramitación incluida en esta historia de ley. 


\section{ÍNDICE}

1. Primer Trámite Constitucional: Cámara de Diputados

Biblioteca del Congreso Nacional de Chile - www.ben.cl/historiadelaley - documento generado el 09-Mayo-2018 
Mensaje

\section{Primer Trámite Constitucional: Cámara de Diputados}

\subsection{Mensaje}

Fecha 22 de mayo, 2002. Mensaje en Sesión 2. Legislatura 347.

MENSAJE DE S.E. EL PRESIDENTE DE LA REPUBLICA CON EL QUE SE INICIA UN PROYECTO DE LEY QUE ESTABLECE UN RÉGIMEN DE GARANTIAS EN SALUD.

SANTIAGO, 22 de mayo de 2002

MENSAJE N2 1-347/

A S.E. EL PRESIDENTE DE LA H. CAMARA DE DIPUTADOS.

Honorable Cámara de Diputados:

En uso de mis facultades constitucionales, vengo en proponer a esa $\mathrm{H}$. Corporación un proyecto de ley que tiene por objeto crear un Régimen de Garantías en Salud.

\section{I.ANTECEDENTES HISTÓRICOS.}

La salud es un producto de la vida en sociedad. Por ello, cada época y cada sociedad tienen su particular estado de salud, generado por la combinación de factores que hacen posible incrementar el bienestar y la calidad de vida de los ciudadanos.

La interacción de esos factores no ha sido históricamente dejada al azar, sino muy por el contrario, han sido políticas pro-activas de los gobiernos las que han permitido identificarlos, a fin de implementar acciones que permitan controlarlos.

En nuestro país en particular, fue la decidida acción del Estado la que permitió alcanzar los indicadores de salud de los que hoy disfrutamos. Por 10 mismo, debemos hacer un nuevo esfuerzo para satisfacer las necesidades crecientes que nuestra misma evolución ha generado.

ii. La década de los cincuenta.

Hace cincuenta años, Chile dio un gran salto con la creación del Servicio Nacional de Salud, que significó la ampliación del acceso a los beneficios sanitarios y el establecimiento de una estructura nacional que definió la responsabilidad del Estado en Salud Pública.

En ese momento, el pais supo definir sus prioridades sanitarias y ordenar sus recursos para proteger eficazmente la salud de la madre y el niño y controlar las enfermedades infecciosas. Como resultado de ello, hoy podemos exhibir las más bajas tasas de mortalidad infantil de la región y estamos cercanos a la eliminación efectiva de la tuberculosis, entre otros logros.

La solidez y fortaleza del Servicio Nacional de Salud no solo permitió mejorar la salud de la población, sino que generó una profunda vinculación entre el quehacer sanitario y el respaldo ciudadano.

iii. La década de los ochenta.

A partir de 1981, el sistema de salud y la cultura sanitaria se debilitaron. Ello obedeció, por una parte, a su fragmentación, resultado del traspaso de la atención primaria a los municipios; y, por otra, a su segmentación, producto de la creación de las Isapres.

Esta tendencia se agravó con la falta de inversión en infraestructura y equipamiento que padeció el sector público durante este periodo. El promedio anual de la inversión sectorial en la década de los ochenta fue apenas de 8.089 millones de pesos. 
Mensaje

\section{iv. La década de los noventa.}

En los años noventa se realizó un considerable esfuerzo de inversión para recuperar la disminuida capacidad productiva de la red pública, en particular la hospitalaria. Estos recursos se destinaron preferentemente a aquellas regiones y establecimientos que presentaban un mayor grado de deterioro de su infraestructura y una mayor vulnerabilidad médico social de su población beneficiaria. El promedio anual de inversión en los noventa fue de 46.729 millones de pesos, cifra seis veces mayor a la de la década anterior.

Al mismo tiempo, se incrementaron las remuneraciones de los trabajadores del sector y se completaron las dotaciones de profesionales, las que acusaban serios déficit.

v. La situación actual.

A pesar de estos ingentes esfuerzos en la última década, el modelo institucional actual ha alcanzado un límite en su capacidad de enfrentar las necesidades sanitarias de la población, lo que se expresa, de un lado, en la insatisfacción de los usuarios con el sistema de salud del país, tanto en el sector público, en que las personas beneficiarias del mismo solicitan una mejoria en la cobertura, en el trato y en la oportunidad, como en el sector privado, en que demandan una mayor protección de sus derechos. Por la otra, es importante reconocer que existen espacios para realizar importantes mejoras de gestión que aseguren que los esfuerzos futuros de inversión se traduzcan en más y mejores prestaciones para la población.

La sociedad chilena no puede seguir tolerando que cada año 700 mujeres mueran de cáncer al útero, cuando una intervención oportuna les podría haber salvado la vida.

Resulta también inaceptable que cada año mueran 2.000 mujeres de cáncer a la vesícula, enfermedad también prevenible y que 1.600 de ellas sean pobres y de baja instrucción.

Tampoco se puede permitir que muchas mujeres que desarrollan un tumor mamario deban esperar demasiado tiempo para la confirmación del diagnóstico y tratamiento correspondiente, lo que disminuye significativamente sus posibilidades de sobrevida.

No se puede, tampoco, permitir que un accidente de tránsito o una enfermedad grave constituyan una causa de empobrecimiento de la familia, como sucede hoy en día con muchos de los beneficiarios del sistema privado, cuyas coberturas financieras resultan insuficientes para solventar los gastos asociados a estas patologías de alto costo.

El dolor de tantas familias chilenas es la motivación para dar este nuevo gran impulso. La reforma al sistema de salud del país intenta responder a las necesidades y expectativas de la población, en un momento en el cual numerosos elementos aconsejan el rediseño de la institucionalidad vigente.

VI.VALORES Y PRINCIPIOS QUE INFORMAN LA REFORMA A LA SALUD.

Los pilares fundamentales sobre los cuales descansa la reforma a la salud que estamos impulsando, pueden resumirse en los siguientes:

vii. Derecho a la salud.

Para el Gobierno, la salud es un derecho de las personas.

Esto significa que toda persona residente en el territorio nacional, independiente de su edad, sexo, educación, etnia, preferencias sexuales o ingreso, debe contar con un mecanismo de protección social y con acceso universal a una atención de salud adecuada y oportuna para enfrentar situaciones de enfermedad, y a la existencia de condiciones saludables en su comunidad y trabajo, dentro de las capacidades y recursos del país.

Para resquardar el derecho a la salud, no basta con su declaración, sino que se hace necesario establecer garantías explícitas de acceso, oportunidad, calidad y protección financiera y generar los instrumentos para el efectivo ejercicio de éstas, dotando a los usuarios de las facultades y mecanismos para hacerlas exigibles.

viii. Equidad en salud. 
REVISTA ANALES

Mensaje

La equidad en salud es un imperativo moral que está en la raíz de la voluntad de reformar.

La reforma de salud propone reducir las desigualdades evitables e injustas, por la vía de otorgar mayores niveles de protección social y acceso universal a la atención de salud.

Hoy, en nuestro país, existen situaciones de desigualdad respecto de la salud de las personas, tanto en el acceso a los servicios como en los resultados observados en los indicadores nacionales, que se expresan, entre otros, en diferencias significativas en la esperanza de vida y en la discapacidad, estrechamente relacionadas con los niveles de instrucción, ingreso y ocupación de las personas.

La inequidad es producto de una forma de organización social que genera exclusión y marginación del progreso económico y social, que abarca muchas esferas de la vida de las personas. Sin embargo, es en el ámbito de la salud donde se expresa con singular dureza la disminución de la esperanza y calidad de vida de las personas y un aumento de la discapacidad y dependencia.

Por el contrario, la equidad es el resultado de una acción intencionada para identificar y disminuir los factores o condiciones que generan las desigualdades evitables y a ello tenemos que dedicar nuestros mayores esfuerzos.

Así, la mortalidad infantil ha mostrado un sostenido descenso en las tasas, desde 32 por 1.000 nacidos vivos en 1980 a 10 por 1.000 nacidos vivos en 1998 . Sin embargo, detrás de estas cifras se esconden grandes diferencias geográficas y por estrato socioeconómico, que resultan en brechas de equidad. Por ejemplo, un niño hijo de una madre sin instrucción, tiene un riesgo de morir en el primer año de vida 5 veces mayor que un hijo de una madre con instrucción; y se registran diferencias de hasta 15 veces en la mortalidad infantil de comunas urbanas de alto nivel socioeconómico con sus homónimas rurales y pobres.

ix. Solidaridad en salud.

Otro de los principios que inspiran la reforma es la solidaridad, entendida como el esfuerzo intencionado que hace la sociedad chilena para que los más vulnerables tengan iguales garantías que los más favorecidos.

Igualar garantías implica que los sanos solidarizan con los enfermos, los hombres con las mujeres, los jóvenes con las personas de edad avanzada y los ricos con los pobres.

x. Eficiencia en Uso de Recursos.

Para poder materializar los valores de equidad y solidaridad en salud, de forma que los ciudadanos puedan hacer efectivo su derecho a la misma, es condición necesaria alcanzar un alto nivel de eficiencia en el uso de los recursos que crecientemente se invertirán en el sector.

Es reconocido el esfuerzo de inversión fiscal que se ha realizado en la última década en el sistema de salud, destinado principalmente a recuperar la infraestructura pública, fortalecer la atención primaria y recuperar e poder adquisitivo de las remuneraciones del personal del sector.

Sin embargo, existe evidencia que este esfuerzo podría haberse reflejado de manera más significativa en la cantidad y calidad de las prestaciones otorgadas a la ciudadanía. Existe, por lo tanto, un espacio para lograr mayor eficiencia en el uso de los recursos, que se traduzca en una mejor atención médica y un mejor trato para la población.

Esta mayor eficiencia debe alcanzarse a través de mejoras de gestión, que involucran tanto los ámbitos de recursos humanos y financieros, donde es necesario terminar con problemas de administración de personal y de deuda, entre otros; como a los propios beneficiarios, en lo referente a una mejor focalización y uso de los subsidios en salud.

En consecuencia, el compromiso de lograr una mayor eficiencia en el uso de los recursos implica un esfuerzo tanto de prestadores como de usuarios, y va en directo beneficio de la salud de la población.

xi. Participación social en salud

La participación social en la formulación, puesta en marcha y evaluación de las políticas y programas sectoriales, 
Mensaje

constituye una dimensión importante de la vida cívica democrática.

Implica reconocer a las personas como usuarios y ciudadanos ante los cuales el sistema de salud debe dar cuenta de la calidad, efectividad y oportunidad de servicio, asi como del uso eficiente de los recursos.

Permite, asimismo, que los ciudadanos expresen sus preferencias y expectativas respecto al sistema de salud y las correspondientes políticas públicas.

La participación ciudadana debe comprenderse como un mecanismo de mejoramiento social de las actividades de salud.

La adecuada e informada participación de los usuarios, requiere transparencia para llevar a cabo el proceso y para conocer sus resultados. Ello asegurará la legitimación social de nuestro sistema de salud y la superación de la insatisfacción ciudadana que hemos registrado en los últimos años. Definir un modelo de participación adecuado a nuestra realidad e implementarlo, es propósito de la reforma a la salud.

Para un proceso de mejoramiento integral, profundo y eficiente del sistema de salud es necesario darle la mayor relevancia a la interlocución con los actores sociales involucrados, cómo se compromete su participación, y cómo se generan mecanismos para conocer y aprovechar sus aportes.

Nuestro compromiso con el derecho a la salud y los valores de equidad, solidaridad, eficiencia y participación es éticamente insoslayable y socialmente indispensable.

XII. FUNDAMENTOS SOCIALES Y SANITARIOS DE LA REFORMA A LA SALUD.

xiii. Expectativas de la población.

La población, cada vez mejor educada e informada de sus derechos, tiene expectativas crecientes respecto a los servicios de salud.

Hoy en día las personas exigen ser tratadas con dignidad, que se les informe respecto a sus alternativas terapéuticas y que se les otorgue la oportunidad de decidir respecto a su salud. También desean que se les atienda en forma oportuna y con una calidad de servicio adecuada y, sobretodo, que se le resuelva su problema.

xiv. Perfil epidemiológico y çambios demográficos.

Nuestro país vive un proceso de transformación del perfil de enfermedades que afectan a la población, como consecuencia del progresivo envejecimiento de ésta, del cambio en los hábitos de vida y de las condiciones de trabajo.

Esta transición forma parte de cambios sociales, económicos y culturales, insertos en un mundo globalizado.

Lo anterior significa que coexisten problemas de salud de diversa índole. Por una parte, enfermedades infecciosas y problemas derivados de malas condiciones de saneamiento ambiental propios de una sociedad en desarrollo; y por otra, enfermedades cardiovasculares, cánceres y traumatismos, que predominan en el patrón de mortalidad actual y que se asemejan al perfil epidemiológico de una sociedad desarrollada.

Los siguientes ejemplos confirman la necesidad de un manejo diferente al de hoy para alcanzar las metas sanitarias que el pais se ha propuesto.

$\mathrm{xV}$. Enfermedades cardiovasculares.

Las enfermedades cardiovasculares constituyen la primera causa de muerte en Chile $(27,1 \%$ del total de las defunciones en 1998).

La hipertensión arterial afectaria al 18\% de la población mayor de 20 años, esto es, más de 1.700 .000 personas, de las cuales sólo un $10 \%$ de ese total es diagnosticada y un porcentaje aun menor adhiere a programas de control (Encuesta de Calidad de Vida y Salud, MINSAL-INE 2000).

El adecuado control de la hipertensión arterial y otros factores de riesgo como el tabaquismo, la obesidad, el 
REVISTA ANALES

Mensaje

sedentarismo y una dieta inadecuada, permitirá reducir la prevalencia de estas enfermedades. De esta misma forma, el acceso a intervenciones clínicas eficaces también es fundamental para mejorar la sobrevida.

\section{xvi. Cáncer.}

Cada día mueren alrededor de 50 chilenos por cáncer y cada año se producen alrededor de 36.000 hospitalizaciones por ésta enfermedad y se estima que anualmente se diagnostican más de 30.000 nuevos casos de los cuales mueren más del $60 \%$

El cáncer ocupa el segundo lugar en las causas de muerte del país, con el $22 \%$ del total de las ocurridas el año 1998.

Tres de los cánceres que causan más muertes en las chilenas, cáncer de vesícula biliar, cáncer de mama y cáncer cervicouterino, tienen exámenes de detección precoz que permiten su prevención. Otros cánceres como los infantiles, incluyendo leucemia y linfoma, y el cáncer de testículo, tienen buen pronóstico con el diagnóstico precoz y el tratamiento oportuno.

xvii. Diabetes Mellitus.

En Chile, el 3,2\% de la población dice haber sido diagnosticado con esta enfermedad, porcentaje equivalente a más de 300.000 personas, según la Encuesta de Calidad de Vida y Salud MINSAL-INE 2000, en tanto se estima que una cifra similar padece la enfermedad pero no ha sido diagnosticada y por lo tanto, enfrenta un mayor riesgo de presentar complicaciones.

La diabetes representa la séptima causa de muerte en Chile, según datos del Ministerio de Salud de 1998 , principalmente por la enfermedad cardiovascular asociada a la misma. Es, asimismo, la principal causa de amputación por causa no traumática y también una de las principales causas de ceguera y de insuficiencia renal crónica.

Evitar que la diabetes derive en complicaciones graves requiere su detección precoz, control metabólico adecuado desarrollo de hábitos saludables, todo lo cual se puede llevar a cabo en la Atención Primaria.

xviii. Obsolescencia del modelo de atención de salud.

El nuevo perfil epidemiológico exige transformaciones y adaptaciones al actual modelo de atención, cuyo diseño fue concebido para una época con otras necesidades. Una expresión concreta de la limitada capacidad del sector público de atender a las nuevas demandas la representan las "listas de espera" de consultas de especialidades, que consignan que más de 200.000 personas esperan para ser atendidos por una especialista.

El modelo vigente es básicamente curativo y centrado en el hospital como la gran instancia de resolución de los problemas de salud. Hoy día este sistema se hace insuficiente para enfrentar los nuevos desafíos derivados de mejorar la salud de la población adulta y de tercera edad.

Por otra parte, los esfuerzos realizados para fortalecer el nivel primario de atención han sido limitados, lo que se manifiesta en la baja capacidad para resolver los problemas emergentes que éste exhibe en la actualidad.

El desafío de la reforma es desarrollar un modelo de atención que enfatice la promoción y la prevención y que se centre en la atención primaria y en la resolución ambulatoria e integral de la mayor parte de los problemas de salud.

Este modelo persigue maximizar el impacto sanitario de sus acciones mediante un uso racional de los recursos, estimulando aquellas intervenciones que tienen eficacia y efectividad cientificamente demostrada.

La modernización del modelo de atención implica también superar la actual fragmentación del sistema de salud, estableciendo los mecanismos e incentivos que aseguren una adecuada coordinación entre los distintos niveles de atención.

XIX. MATERIAS QUE SE DEBEN ABORDAR EN LA REFORMA A LA SALUD. 
Mensaje

Considerando estos hechos, valores y fundamentos, tenemos la convicción de la necesidad de llevar a cabo una reforma a la salud, la cual, necesariamente, es compleja, por cuanto se deben abordar un conjunto integral y coherente de materias, algunas de las cuales requerirán de nuevas leyes o de modificaciones a las actuales. Para que esta reforma logre su desafío, es necesario asegurar la integralidad de sus componentes.

xx. Definición de los Objetivos Nacionales de Salud.

La formulación de Objetivos Nacionales de Salud es un componente esencial de la reorientación de las políticas públicas en salud, ya que en el pasado fue precisamente la fijación de objetivos claros, medibles y practicables, lo que permitió los grandes avances en la salud de la población que se han señalado.

En el marco de la reforma, estos objetivos son el referente principal para establecer prioridades, definir estrategias y planificar las actividades necesarias para mejorar la salud de la población.

En este sentido, creemos que las metas que nos debemos plantear para la década 2000 - 2010, deben orientarse a:

a) Disminuir las desigualdades en salud.

b) Enfrentar los desafíos del envejecimiento de la población y de los cambios de la sociedad.

c) Proveer servicios acordes con las expectativas de la población.

d) Mejorar los logros sanitarios alcanzados.

xxi. El Sistema de Acceso Universal con Garantías Explícitas (AUGE).

El derecho a la salud, señalado como elemento esencial de la política de Gobierno, deberá ser garantizado a la población mediante un conjunto de disposiciones legales y reglamentarias que permitan el ejercicio del mismo, con respaldo de una institucionalidad adecuada.

Más adelante explicaremos en detalle esta materia, por cuanto el presente proyecto de ley, precisamente, aborda uno de los componentes del AUGE, que pretendemos instaurar en nuestro pais, y que dice relación con el Régimen de Garantías en Salud.

No obstante, es preciso, en todo caso, efectuar un par de reflexiones sobre la materia.

En efecto, un sistema de salud existe para proteger la salud de las personas y para, en el evento que ella sea afectada, remediar o paliar sus efectos negativos.

Desde esta perspectiva, es posible distinguir dos componentes. Un primer elemento está constituido por las acciones de salud pública. Un segundo elemento lo constituyen las prestaciones para hacer frente a un conjunto de enfermedades y condiciones de salud.

xxii. El componente de salud pública del Sistema de Acceso Universal con Garantías Explícitas (AUGE).

El primer componente es el conjunto sistemático de acciones de salud, consideradas "bienes de salud pública", destinadas a proteger la salud de las personas de los riesgos del ambiente y otros condicionantes, y a promover la creación de condiciones saludables en la vivienda, la ciudad y el trabajo y a la adopción de comportamientos colectivos e individuales que mantengan sana a la población.

Algunas acciones son de carácter colectivo o poblacional, como por ejemplo las acciones ambientales y la educación en salud, y otras son aplicadas a los individuos, por ejemplo las vacunas.

El componente de Salud Pública se financia actualmente mediante aporte fiscal y es elaborado, evaluado y administrado por el Ministerio de Salud.

Su ejecución está a cargo, en un ámbito sectorial o intersectorial, de instituciones públicas y privadas, en una relación de complementariedad. 
REVISTA ANALES

Mensaje

Para su formulación, se deben considerar los Objetivos Nacionales de Salud, el avance en el cumplimiento de los mismos, la evidencia sobre la efectividad de las intervenciones propuestas y la evolución de la situación sanitaria del país.

xxiii. El componente de salud de las personas del Sistema de Acceso Universal con Garantías Explícitas (AUGE).

Este segundo componente es el conjunto de enfermedades y condiciones de salud, priorizadas de acuerdo a la importancia sanitaria, efectividad del tratamiento, impacto financiero sobre las familias y las expectativas de las personas.

Para estas patologías, actualmente, se determinan acciones y prestaciones preventivas, curativas, de rehabilitación y paliativas, necesarias y efectivas para resolver integralmente los problemas de salud de las personas.

No obstante, se hace necesario introducir a este componente un conjunto de perfeccionamientos, de modo de asegurar efectivamente su funcionamiento.

Es así como se requiere de un Régimen de Garantías en Salud que establezca diferentes niveles de garantías, muchas de ellas explícitas en tiempos de espera, complejidad de la atención y cobertura financiera, exigibles por las personas y fiscalizadas por la autoridad de salud, que lo transformen en el instrumento esencial para asegurar el acceso equitativo y no discriminatorio al sistema de atención de salud.

Este componente debe ser obligatoriamente asegurado a los beneficiarios, tanto del Fondo Nacional de Salud como de las Instituciones de Salud Previsional, instituciones que deben ser responsables del cumplimiento de las garantías explicitadas.

En el caso del Fondo Nacional de Salud, si la oferta pública no fuera suficiente para satisfacer las necesidades de los pacientes, dicha institución deberá comprar aquellas prestaciones necesarias en el sector privado.

Asimismo, las Instituciones de Salud Previsional deberán entregar este componente sin discriminación de precios a todos sus beneficiarios. Esto permitirá desvincular el costo de los seguros del riesgo individual de enfermar. Asi, se materializará la solidaridad entre sanos y enfermos, jóvenes y viejos, hombres y mujeres.

xxiv. Nuevo modelo de atención.

Una tercera materia a abordar en el proceso de reforma que proponemos, dice relación con el modelo de atención.

Este modelo debe, en lo esencial, satisfacer las necesidades y expectativas del usuario y optimizar las intervenciones, en su eficiencia y eficacia.

El nuevo modelo de atención debe tener una fuerte orientación a la promoción de la salud, es decir, a la eliminación de factores de riesgo de enfermar por condicionantes ambientales y sociales y a la creación de condiciones materiales y modificaciones conductuales para una vida saludable; la prevención de las enfermedades mediante la pesquisa oportuna de factores de riesgo o el diagnóstico precoz de las enfermedades; la atención oportuna y permanente de las enfermedades en los niveles de complejidad más adecuados, procurando una eficaz integración al interior de las redes asistenciales, superando la fragmentación y descoordinación hoy existente.

Para ello, se impulsará una atención primaria altamente resolutiva, con capacidad para solucionar gran parte de las emergencias, donde existirán equipos de salud familiar y comunitaria "de cabecera", con una cantidad definida de familias a cargo, dotados de la tecnología y equipamiento necesario y trabajando coordinadamente con la atención de especialidad.

El segundo nivel de atención estará formado por establecimientos y hospitales que resolverán las derivaciones de primer nivel, privilegiando las actividades ambulatorias.

En el sistema público, cada vez que una persona sea hospitalizada tendrá un profesional asignado, que asumirá la responsabilidad de su cuidado, establecerá los contactos con familiares y con su equipo de salud de la atención primaria. 
Mensaje

\author{
xxv. Recursos Humanos.
}

Una cuarta materia que debemos abordar es la relativa a los recursos humanos.

En efecto, los trabajadores de la salud constituyen la pieza fundamental en que se apoya cualquier intento de reforma sectorial, tanto para el cambio en el modelo de atención como en el desarrollo de una orientación hacia el usuario.

Contar con un recurso humano comprometido, requiere de políticas que contemplen su permanente actualización, crecimiento profesional, remuneraciones acordes con sus responsabilidades y desempeño, y espacios de participación.

Tan importante como lo anterior, es dotar a los trabajadores del sector de un entorno laboral confortable y que incorpore los avances de la modernidad y que favorezca la constitución de equipos de trabajo, en que cada integrante pueda aportar su experiencia e ideas al proceso asistencial.

Un renovado compromiso de los trabajadores del sector, llevará a profundizar un modelo laboral participativo, flexible, innovador y que estimule la creatividad y la calidad del servicio a entregar. Para ello será necesario el desarrollo de una política de personal al interior del sector público que dé cuenta de las particularidades del sector salud, combinando los requerimientos de organización y gestión local con la mantención de un sistema global.

Se trata de definir objetivos comunes por establecimiento y equipos de trabajo coherentes con la red, la integración real de todos los estamentos en las diferentes instancias de participación, la adecuación de las dotaciones con los nuevos perfiles epidemiológicos, las necesidades de la población y las metas planteadas.

xxvi. Autoridad Sanitaria.

Una quinta materia que debe revisarse, dice relación con la autoridad sanitaria.

En efecto, para implementar la reforma y regular el funcionamiento de las instituciones públicas y privadas, se requiere de un Ministerio de Salud rector, con potestades regulatorias y fiscalizadoras, capaz de detectar nuevos problemas de salud, anticipando soluciones, y de controlar aquellos que ya hoy constituyen amenazas para la sociedad chilena.

Para lo anterior es clave la separación de funciones y una identificación precisa de los ámbitos de responsabilidad, de manera de reforzar el control de gestión y la rendición de cuentas ante la ciudadania.

Así, concentrar al Ministerio en las tareas de rectoría y regulación, implica desligarlo de obligaciones vinculadas a la gestión del sistema público, que hoy ocupan gran parte de su quehacer, tanto a nivel del financiamiento como de las atenciones de salud.

La Autoridad Sanitaria, en consecuencia, deberá velar para que todos los establecimientos asistenciales, tanto públicos como privados, estén acreditados en su capacidad de entregar una atención de calidad y sean complementarios para la mejor utilización de los recursos disponibles en el país.

xxvii. Financiamiento.

Un elemento crucial en el éxito de la reforma, lo constituye su financiamiento.

Para tal efecto, se propondrá la creación de un Fondo Solidario, para financiar las cotizaciones de los indigentes en el Fondo Nacional de Salud. Este Fondo Solidario se financiará con recursos fiscales que provendrán de reasignaciones, mejoras en la gestión y focalización, crecimiento de la economía, e impuestos a los males. Esto último, además de tener un objetivo de recaudación solidario, es eficiente al desincentivar el consumo de productos dañinos para la salud de la población.

Dentro de las mejoras en la gestión y focalización, debe resaltarse que el pago de los subsidios maternales se hará solidariamente, por la vía de las cotizaciones de salud de hombres y mujeres, sin alterar los beneficios a que hoy tienen derecho las mujeres trabajadoras y previniendo, asi, eventuales discriminaciones contra ellas. Se introduce, de este modo, un elemento de equidad, hoy ausente, entre beneficios y contribuciones. 
REVISTA ANALES

Mensaje

xxviii. Mejoramientos de gestión.

Finalmente, otra materia a abordar en la reforma a la salud que se busca, se refiere a las mejoras de gestión, lo que constituye una obligación moral del Estado, siendo su responsabilidad ante la ciudadanía asegurar el máximo de eficiencia en el uso de los recursos públicos.

La eficiencia es hoy, más que nunca, un imperativo ético, ya que mientras mejor se utilicen los recursos disponibles, mayor cobertura y calidad otorgaremos a la población. Esto es particularmente relevante en un contexto donde los recursos serán siempre escasos en relación a la magnitud de las necesidades. En este sentido. tenemos que insistir en la eficiencia y en la necesidad de rendición de cuenta por parte de los directivos del sistema público de salud.

Por ello, entre otras medidas, se requiere:

a)Que todos los incrementos de recursos que se destinen a los servicios de salud en los próximos años se efectúen de acuerdo a la demanda efectiva por prestaciones que éstos enfrenten.

b) Que los incrementos de remuneraciones al personal profesional, técnico y administrativo que se desempeña en los servicios públicos de salud se vincule a su desempeño, y que los incrementos en remuneraciones generales o bases sean atendidos exclusivamente a través de los reajustes generales de remuneraciones en el sector público.

c) Que, respetando la estabilidad, se incremente la flexibilidad en el manejo de los recursos humanos al interior de los servicios de salud, para lo que se requerirá de los jefes de servicios hacer pleno uso de sus facultades para la asignación de personal entre los hospitales y servicios clínicos de su dependencia, evitando la inamovilidad del personal de planta

d) Que se exija al personal el cumplimiento pleno de sus obligaciones funcionarias, desapareciendo el incumplimiento horario, asi como la atención de pacientes privados sin el respectivo convenio con el hospital. Asimismo, se requiere que el ausentismo entre el resto del personal se adecue a niveles normales.

e) Que se optimice el aprovechamiento de la capacidad profesional de los médicos en los hospitales públicos, descargándolos de funciones que pueden ser cumplidas por otros profesionales; así como el empleo de profesionales no médicos para procedimientos en los que sea factible la sustitución.

f)Que se promueva entre los directores de establecimientos el pleno uso de sus facultades administrativas identificando como clara prioridad la satisfacción de las necesidades de los usuarios.

g) Que se establezca un riguroso sistema de control de gestión. Para ello, deben considerarse metas sanitarias, administrativas y financieras. Con el pleno desarrollo del Programa de Prestaciones Valoradas como principa mecanismo de asignación de recursos dentro del sistema, no será justificable que los hospitales incurran en un sobreendeudamiento con proveedores.

h) Que se controle rigurosamente el fraude y el abuso en los subsidios de salud, el pago de prestaciones por pacientes no indigentes y el uso del sistema de medicina curativa de libre elección. Asimismo, se requiere revisar y reforzar la institucionalidad en la que se insertan estos servicios, de modo de generar incentivos a una fiscalización y cumplimiento efectivos.

\section{EL ITINERARIO LEGAL DE LA REFORMA}

Como vemos, la reforma a la salud nos exigirá a todos y cada uno de quienes ejercemos la función pública, de nuestro mayor esfuerzo y dedicación, para obtener un sistema acorde con las necesidades del país.

En este sentido, resulta útil destacar que ya en el año 2001 presentamos a consideración de ese $\mathrm{H}$. Congreso, un proyecto de ley denominado "De los Derechos y Deberes de las Personas en Salud", el cual pretende "empoderar" a las personas en su relación con el sistema de salud.

El segundo proyecto, que es el que en esta oportunidad presentamos, establece las bases para la aplicación de un instrumento que permita priorizar las actividades de salud, asignándoles garantías explícitas de acuerdo a su nivel de importancia para la salud de las personas y los objetivos sanitarios del país. 
Mensaje

El cumplimiento de las garantías establecidas, va a requerir una nueva institucionalidad sectorial que permita una formulación precisa de las políticas de salud, normas e instrumentos de fiscalización.

Las iniciativas legales que se enviarán próximamente al $\mathrm{H}$. Congreso Nacional, y que forman parte de una reforma integral, coherente e inseparable, serán las siguientes:

1.- Proyecto de ley sobre Autoridad Sanitaria, que fortalecerá las atribuciones del Ministerio de Salud y de sus organismos descentralizados, de manera de concentrarlos en funciones que les debieran ser propias.

2.- Proyecto de ley que introduce diversas modificaciones a la Ley $\mathrm{N}^{\circ} 18.993$, toda vez que la comunidad nacional, a través del Poder Legislativo, ha demandado en reiteradas oportunidades una mayor regulación en el ámbito de la salud privada, otorgando mayores facultades de fiscalización a la Superintendencia del ramo y comprometiendo a éstas en una mayor integralidad en las atenciones de salud que entregan.

3.- Iniciativas legales sobre Mejoras de Gestión, ya que urge contar con un sistema eficiente en el manejo de los recursos que sustente efectivamente la entrega de atención oportuna y de calidad a la población. Para este propósito, se encuentra en elaboración un conjunto de iniciativas legales que abarcarán los ámbitos de administración de recursos humanos, transferencias financieras a los servicios, uso de subsidios en salud, y focalización de beneficios en la población de menores recursos. 4.- Iniciativas legales sobre financiamiento, con el objeto de respaldar, de manera solidaria, las cotizaciones de los indigentes en el Fondo Nacional de Salud, y así asegurar su cobertura.

\section{CONTENIDO DEL PROYECTO.}

El presente proyecto de ley reafirma los valores sobre los cuales se construyó la estructura institucional de la salud pública chilena, adecuándola a los desafíos epidemiológicos y a las necesidades actuales de una población más informada, culta y exigente que hace 50 años, dotándola de derechos exigibles para hacer efectivas las garantías contenidas en esta incitativa legal, las que sin lugar a dudas contribuirán a alcanzar mejores niveles de salud.

Con este proyecto, estamos dando un paso trascendental en el camino para lograr las profundas transformaciones que permitirán que toda persona tenga, sin discriminaciones por capacidad de pago, género o edad, en un país que tiene limitaciones reales de recursos, una mejor salud y una atención de mayor calidad, más eficiente y oportuna.

xxxi. El Régimen de Garantías en Salud.

La presente iniciativa legal contempla los mecanismos legales necesarios para establecer e implementar el "Régimen de Garantías en Salud", que, en síntesis, implica dotar al Ministerio de Salud de las atribuciones para definir prioridades sanitarias y garantías explícitas.

Resulta importante destacar que las garantías que se explicitarán de acceso, oportunidad, calidad y cobertura financiera, deberán ser iguales para los beneficiarios del sistema público y privado de salud, dando así un paso importante en la disminución de las brechas de equidad que hoy caracterizan al sistema de salud chileno en su conjunto.

xxxii. Criterios para definir el Régimen.

La definición de prioridades deberá considerar, al menos, criterios de magnitud, trascendencia y gravedad de la situación sanitaria presente y futura del país; la efectividad de las acciones necesarias para su control disponibles en el país; la eficiencia de Fonasa e Isapres; el costo asociado a este proceso y su sustentabilidad financiera; así como los valores sociales y culturales pertinentes.

xxxiii. El Consejo Consultivo.

En este proceso de priorización, se ha estimado necesario que participe la sociedad en su conjunto. Para ello, se conforma un Consejo Consultivo encargado de esa tarea y que dé garantías de independencia e idoneidad y cuente con los mecanismos para recoger las inquietudes que al respecto pueda plantear la comunidad.

El Consejo Consultivo estará integrado por nueve profesionales, nombrados por el Presidente de la República, de 
REVISTA ANALES

Mensaje

conocida trayectoria en el campo de la medicina, la salud pública, la economía y disciplinas relacionadas.

La función principal del Consejo será asesorar al Ministro de Salud en todas las materias relacionadas con la evaluación y revisión del Régimen que se crea.

xxxiv. El Régimen de Garantías en Salud se establecerá en un decreto supremo.

Dada la constante evolución, tanto de las enfermedades y condiciones de salud, así como de los avances científicos, se ha estimado necesario que la definición de las patologías y de las prestaciones vinculadas con ellas, así como las garantías explicitas, sean definidas por decreto supremo.

Lo anterior, permitirá reaccionar oportuna y rápidamente ante situaciones nuevas que se presenten, dando la flexibilidad necesaria para tales fines.

xxxv. El Régimen se revisará periódicamente.

Las enfermedades, prestaciones y garantías deberán ser revisadas obligatoriamente cada tres años, período de tiempo suficiente, tanto para incorporar nuevas tecnologias, como para analizar la evolución epidemiológica de la población.

En todo caso, el proyecto permite que, en casos calificados, puedan hacerse revisiones antes de los tres años, para dar cuenta de imprevistos sanitarios que sean necesarios enfrentar.

xxxvi. Otorgamiento de las prestaciones y garantías.

Por otro lado, el proyecto establece que, tanto el Fondo Nacional de Salud como las Instituciones de Salud Previsional, estarán obligados a otorgar las prestaciones y garantias que se definan, a todos los beneficiarios de las leyes № 18.469 y № 18.933 .

Tal obligación, empero, no impide que el Fondo Nacional de Salud otorgue a sus beneficiarios otras prestaciones y beneficios complementarios, que proporcionen mayores niveles de calidad, oportunidad y protección financiera que los establecidos en el Régimen que se crea.

Lo mismo sucede en el caso de las Instituciones de Salud Previsional.

xxxvii. La exigibilidad y protección de los derechos y garantías del Régimen.

xxxviii. Los derechos y garantías que se establecen en el Régimen serán exigibles.

Como es fácil advertir, de nada vale contar con un Régimen de prestaciones adecuado, con garantías explícitas de acceso, calidad, oportunidad y protección financiera, si el ciudadano no tiene las herramientas para hacerlos exigibles.

A este respecto, el presente proyecto cambia el paradigma que, hasta el momento, existe en nuestro derecho.

En efecto, la Constitución Política de la República, a propósito del Recurso de Protección, dispone de un eficaz instrumento para que las personas que vean amenazados, perturbados o privados sus derechos y garantías, puedan obtener de la Justicia la protección debida.

No obstante, dicha acción constitucional solamente otorga amparo a los denominados derechos individuales, es decir, a aquellos derechos civiles y políticos en que es claro el deber de abstención del Estado y demás particulares respecto del ejercicio de los mismos. Así, por ejemplo, se ampara el derecho a la vida, a la igualdad ante la ley, a la libertad de trabajo, etc

Pero no se otorga igual tutela para los llamados derechos sociales, esto es, aquellos que suponen prestaciones por parte del Estado o de privados que otorgan un servicio público.

El presente proyecto de ley, entonces, explícitamente señala que las garantias que establezca el Régimen "serán constitutivas de derechos para los beneficiarios y su cumplimiento podrá ser exigido por éstos ante las autoridades e instancias que correspondan". 
Mensaje

\author{
xxxix. La fiscalización.
}

Es por ello que, para el caso de las Instituciones de Salud Previsional, se contempla expresamente que la fiscalización del Régimen de Garantias en Salud lo efectúe la Superintendencia de Isapres.

En el caso del Fondo Nacional de Salud, el proyecto contempla la creación de un servicio público encargado de la fiscalización del Régimen, denominado "Superintendencia de Garantías en Salud".

Dicha Superintendencia estará facultada, entre otras cosas, para interpretar administrativamente, en lo relativo al Régimen de Garantías en Salud, las leyes, reglamentos y demás normas que rigen al Fondo Nacional de Salud; impartir instrucciones de general aplicación y dictar órdenes para su aplicación y cumplimiento; velar porque el Fondo Nacional de Salud cumpla con las leyes y reglamentos que lo rigen y con las instrucciones que la Superintendencia emita, en todos los aspectos que digan relación con el Régimen de Garantías en Salud, sin perjuicio de las facultades que pudieren corresponder a otros organismos fiscalizadores; y para resolver los reclamos que presenten los beneficiarios de la Ley № 18.469 en contra del Fondo Nacional de Salud en relación al Régimen de Garantías en Salud.

La estructura organizacional, financiamiento y demás normas necesarias para el funcionamiento de la Superintendencia de Garantías en Salud, será materia de un decreto con fuerza de ley, razón por la cual el proyecto contempla que el $\mathrm{H}$. Congreso faculte al Presidente de la República al respecto.

\title{
xi. Adecuación de normas vigentes.
}

Dado que el presente proyecto crea un Régimen nuevo en el sistema de salud, ha sido necesario introducir una serie de modificaciones a las leyes № 18.469 y № 18.933 , de modo de adaptar estos cuerpos legales a la nueva realidad.

En este sentido, una de las modificaciones que se introduce a la Ley que rige al sistema privado de salud, se refiere a que el precio que las Isapres cobren por concepto del Régimen ce Garantías en Salud, deberá ser el mismo, sin que sea factible establecer diferencias por sexo y edad.

xii. Vigencia del primer Régimen de Garantías en Salud.

El proyecto dispone que el primer Régimen de Garantías en Salud deberá establecerse, a más tardar, el último día del tercer mes siguiente a la publicación del reglamento del Consejo Consultivo.

Lo anterior es así, toda vez que no es posible que el primer instrumento que se dicte, no haya sido sometido a la revisión del Consejo. Y dado que, para que éste sesione y adopte acuerdos, necesita del reglamento de funcionamiento del mismo, se ha establecido como hito para el cómputo de plazos precisamente dicho cuerpo normativo.

Publicado el decreto supremo en que conste el primer Régimen de Garantías en Salud, éste comenzará a regir el primer día del cuarto mes siguiente a dicha publicación.

Tal período es necesario para permitir que, tanto el Fondo Nacional de Salud, como las Instituciones de Salud Previsional, adecúen sus procedimientos y puedan garantizar el cumplimiento del mencionado Régimen.

En mérito de lo anteriormente expuesto, someto a vuestra consideración, el siguiente

\section{PROYECTO DE LEY:}

"TITULO I

\section{DEL RÉGIMEN DE GARANTIAS EN SALUD}

Párrafo $1^{\circ}$

\section{Disposiciones Generales}

Artículo $1^{\circ}$.- La presente ley tiene por objeto regular el Régimen de Garantías en Salud, en adelante, también, "el 
REVISTA ANALES

Mensaje

Régimen"

Dicho Régimen es parte integrante del Sistema de Acceso Universal con Garantías Explícitas, junto a las acciones de salud pública elaboradas por el Ministerio de Salud, conforme a la normativa vigente, y a las demás prestaciones a que tienen derecho los beneficiarios de las leyes $\mathrm{N}^{\circ} 18.469$ y $\mathrm{N}^{\circ} 18.933$.

Artículo $2^{\circ}$,-El Régimen es un instrumento de regulación sanitaria de carácter general y obligatorio, elaborado por el Ministerio de Salud, de acuerdo a los objetivos sanitarios, prioridades nacionales, necesidades de las personas y a los recursos de que disponga el país.

Artículo $3^{\circ}$.- El Régimen establecerá un conjunto priorizado de enfermedades y condiciones de salud y las prestaciones de salud asociadas a ellas, de carácter promocional, preventivo, curativo, de rehabilitación y paliativo, con garantías explícitas relativas a acceso y a niveles de oportunidad, protección financiera y calidad de las mismas, que el Fondo Nacional de Salud y las Instituciones de Salud Previsional deberán asegurar a sus respectivos beneficiarios.

Artículo $4^{\circ}$.- El Régimen consagrará el acceso a prestaciones de salud con determinados niveles de oportunidad protección financiera y calidad.

La oportunidad se definirá conforme a parámetros y criterios clínicos generalmente aceptados y factibles de cumplir.

Los estándares de calidad deberán tener en consideración la evidencia científica respecto de la eficacia o efectividad de las prestaciones y establecer las condiciones de entrega de éstas.

Para determinar la protección financiera, se deberá considerar, a lo menos, la condición socioeconómica del beneficiario, el tipo de enfermedad o condición de salud, su costo y su impacto sanitario.

Artículo $5^{\circ}$ - Para los efectos de esta ley, se entiende por:

a) Acceso: Derecho a recibir las prestaciones de salud, en la forma y condiciones que determine el Régimen de Garantías en Salud.

b) Calidad: Estándar que deben cumplir las prestaciones de salud y las condiciones de otorgamiento de las mismas, en la forma y condiciones que determine el Régimen de Garantías en Salud.

c) Oportunidad: Plazo máximo para la entrega de prestaciones de salud, en la forma y condiciones que determine el Régimen de Garantías en Salud.

d) Protección Financiera: Proporción en que el Fondo Nacional de Salud o la Institución de Salud Previsional, según corresponda, concurren al financiamiento de las prestaciones de salud, en la forma y condiciones que el Régimen de Garantías en Salud señale.

Dichas garantías serán constitutivas de derechos para los beneficiarios y su cumplimiento podrá ser exigido por éstos ante las autoridades e instancias que correspondan.

Párrafo $2^{\circ}$

De la Elaboración del Régimen de Garantías en Salud

Artículo $6^{\circ}$ - El Régimen será elaborado y revisado por el Ministerio de Salud, con la asesoría del Consejo Consultivo, y deberá ser aprobado por Decreto Supremo de dicho Ministerio, suscrito además por el Ministro de Hacienda.

Corresponderá al Ministerio de Salud, mediante resolución y en el marco de los recursos disponibles, fijar las normas técnicas y médicas de general aplicación que fueran necesarias para la debida ejecución y cumplimiento del Régimen.

Un Reglamento establecerá el procedimiento de elaboración del Régimen que considerará, a lo menos, las siguientes etapas: análisis técnico y económico; desarrollo de estudios; consulta a organismos competentes para 
Mensaje

recabar las propuestas, observaciones o consideraciones relativas a los aspectos técnicos, sanitarios y económicos del mismo, los que serán evaluados en la definición de la estructura, contenidos y sus garantias explicitas.

Artículo $7^{\circ}$.- El Ministerio de Salud elaborará la propuesta del Régimen, que someterá a la opinión del Consejo Consultivo, tomando en consideración la magnitud, trascendencia y gravedad de la situación sanitaria presente y futura del pais; la efectividad de las prestaciones necesarias para su control; la infraestructura, equipamiento y recursos humanos disponibles en el país; la eficiencia del Fondo Nacional de Salud y de las Instituciones de Salud Previsional; el costo asociado a este proceso y su sustentabilidad financiera, asi como los valores sociales y culturales involucrados en su definición.

Párrafo $3^{\circ}$

Del Consejo Consultivo del Régimen de Garantías en Salud

Artículo $8^{\circ}$.- Habrá un Consejo Consultivo del Régimen de Garantías en Salud, en adelante el Consejo, con carácter asesor y técnico. Su objetivo será asesorar al Ministro de Salud en todas las materias relacionadas con la evaluación y revisión de dicho Régimen.

Artículo $9^{\circ}$. - El Consejo estará compuesto de nueve miembros de reconocida idoneidad en el campo de la medicina, salud pública, economía y disciplinas relacionadas.

Dichos Consejeros serán nombrados por el Presidente de la República a propuesta del Ministro de Salud, por un período de seis años, prorrogables por una sola vez y no percibirán remuneración alguna por su desempeño.

Un Secretario Ejecutivo, nombrado por el Ministro de Salud, coordinará el funcionamiento del Consejo, realizando las labores que para tal efecto defina el Reglamento.

Artículo 10.- El Consejo, dentro del plazo que al efecto fije el reglamento, conforme a los objetivos sanitarios, prioridades nacionales y al marco presupuestario definido, emitirá una opinión fundada al Ministro de Salud sobre el Régimen propuesto.

Para cumplir con lo dispuesto en el inciso precedente, los Consejeros deberán contar con los estudios y antecedentes técnicos entregados por el Ministerio, el que los hará llegar con, a lo menos, sesenta días de anticipación a la fecha de su convocatoria.

Artículo 11. - Un Reglamento establecerá el funcionamiento del Consejo y el procedimiento a seguir para la evaluación del Régimen, que considerará, a lo menos, las siguientes materias: número mínimo de Consejeros necesarios para sesionar y adoptar acuerdos; procedimientos para dar cuenta pública de sus sesiones y de los criterios técnicos, científicos y sanitarios aplicados en su evaluación, y el plazo para evacuar el informe.

Párrafo $4^{\circ}$

De la Revisión del Régimen de Garantías en Salud

Artículo 12.- El Régimen deberá ser revisado cada tres años, contados desde la fecha de publicación del decreto respectivo que lo apruebe. No obstante lo anterior, en circunstancias calificadas, el Presidente de la República podrá disponer su revisión antes de cumplirse el plazo indicado, mediante la dictación de un Decreto Supremo fundado.

Las modificaciones al Régimen deberán entrar en vigencia no antes de sesenta días contados desde la fecha de publicación del decreto respectivo, sin perjuicio de que, en circunstancias calificadas y fundamentadas en éste, se pueda establecer un plazo inferior de vigencia.

\section{Párrafo $5^{\circ}$}

De la Obligatoriedad en el Otorgamiento del Régimen de Garantías en Saluc

Artículo 13.- El Régimen deberá ser otorgado obligatoriamente a los beneficiarios de la ley $\mathrm{N}^{\circ} 18.469$ y a los de las Isapres, por el Fondo Nacional de Salud y por las Instituciones de Salud Previsional, respectivamente. 
REVISTA ANALES

Mensaje

Artículo 14.- El Fondo Nacional de Salud podrá otorgar a los beneficiarios de la ley $\mathrm{N}^{\circ} 18.469$, otras prestaciones 0 beneficios complementarios que proporcionen mayores niveles de calidad, oportunidad y protección financiera, que los contemplados en el Régimen de Garantías en Salud.

Por su parte, las Instituciones de Salud Previsional podrán ofrecer a sus beneficiarios planes complementarios a Régimen de Garantias en Salud vigente, de conformidad a lo dispuesto en la letra a), del artículo 33 , de la Ley $\mathrm{N}^{\circ}$ 18.933. Dichos planes deberán especificar los beneficios complementarios ofrecidos y el precio adicional de éstos, si correspondiere.

TÍTULO॥

DE LA FISCALIZACIÓN DEL RÉGIMEN DE GARANTIAS EN SALUD

Párrafo $1^{\circ}$

De la Superintendencia de Garantías en Salud

Artículo 15.- Créase la Superintendencia de Garantias en Salud, en adelante "la Superintendencia", organismo funcionalmente descentralizado, dotado de personalidad jurídica y patrimonio propio, que se relacionará con el Presidente de la República a través del Ministerio de Salud.

Corresponderá a la Superintendencia fiscalizar y controlar al Fondo Nacional de Salud en el cumplimiento de Régimen de Garantías en Salud que se otorgue a los beneficiarios de la Ley № 18.469 .

Artículo 16. - Un funcionario nombrado por el Presidente de la República y de su exclusiva confianza, con el título de Superintendente, será el Jefe Superior de la Superintendencia, y tendrá la representación judicial y extrajudicial de la misma.

Artículo 17.- Serán funciones específicas de la Superintendencia, entre otras:

1.- Interpretar administrativamente, en lo relativo al Régimen de Garantías en Salud, las leyes, reglamentos y demás normas que rigen al Fondo Nacional de Salud; impartir instrucciones de general aplicación y dictar órdenes para su aplicación y cumplimiento.

2.- Velar porque el Fondo Nacional de Salud cumpla con las leyes y reglamentos que lo rigen y con las instrucciones que la Superintendencia emita, en todos los aspectos que digan relación con el Régimen de Garantías en Salud, sin perjuicio de las facultades que pudieren corresponder a otros organismos fiscalizadores.

3.- Resolver, en los términos a que se refiere el artículo 21 , los reclamos que presenten los beneficiarios de la Ley NN 18.469 en contra del Fondo Nacional de Salud en relación al Régimen de Garantías en Salud.

4.- Dictar las instrucciones de carácter general que permitan dar cumplimiento al Régimen de Garantías en Salud.

5.- Requerir de los organismos del Estado los informes que estime necesarios para el cumplimiento de sus funciones.

6.- Efectuar publicaciones informativas acerca de los beneficios que contempla el Régimen de Garantías en Salud. así como las medidas adoptadas respecto del Fondo Nacional de Salud para velar por el correcto funcionamiento de dicho Régimen.

7.- Imponer las sanciones que establezca la ley.

8.- Ordenar al Fondo Nacional de Salud la devolución de lo pagado en exceso por el beneficiario en el otorgamiento de prestaciones conforme lo dispuesto en el Régimen de Garantías en Salud.

9.- Las demás que le señalen las leyes.

Artículo 18.- Las órdenes que contengan la obligación de devolver sumas de dinero, así como las sanciones de pago de multa, constituirán título ejecutivo para todos los efectos legales, una vez que se hayan resuelto los recursos a que se refieren los artículos siguientes, o haya transcurrido el plazo para interponerlos. 
Mensaje

Artículo 19.- En contra de las resoluciones o instrucciones administrativas que dicte la Superintendencia, podrá deducirse recurso de reposición ante esa misma autoridad dentro del plazo de cinco días hábiles, contados desde la fecha de la notificación de la resolución o instrucción.

La Superintendencia deberá pronunciarse sobre el recurso, en el plazo de cinco días hábiles, desde que se interponga.

Artículo 20.- Resuelto por la Superintendencia el recurso de reposición, el afectado podrá reclamar de ella dentro del plazo de 15 días hábiles, contado desde la notificación de la medida, ante la Corte de Apelaciones que corresponda, la que deberá pronunciarse en cuenta sobre la admisibilidad del reclamo y si éste ha sido interpuesto dentro del término legal. Admitido el reclamo, la Corte dará traslado por quince días hábiles a la Superintendencia. Evacuado el traslado, la Corte ordenará traer los autos "en relación", agregándose la causa en forma extraordinaria a la tabla del día siguiente, previo sorteo de Sala cuando corresponda. Si el tribunal no decretare medidas para mejor resolver, dictará sentencia dentro del plazo de treinta días, y si las ordenare, en el plazo de diez días de evacuadas ellas.

Para reclamar contra resoluciones que impongan multas $u$ ordenen la devolución de sumas de dinero, debera consignarse, previamente, en la cuenta del tribunal, una cantidad igual al veinte por ciento del monto de dicha multa o devolución, que no podrá exceder de cinco unidades tributarias mensuales, conforme al valor de éstas a la fecha de la resolución reclamada, la que será aplicada en beneficio fiscal si se declara inadmisible o se rechaza el recurso. En los demás casos, la consignación será equivalente a cinco unidades tributarias mensuales, vigentes a la fecha de la resolución reclamada, destinándose también a beneficio fiscal, en caso de inadmisibilidad o rechazo del recurso.

La resolución que expida la Corte de Apelaciones será apelable en el plazo de cinco días, recurso del que conocerá en cuenta una Sala de la Corte Suprema, sin esperar la comparecencia de las partes, salvo que estime traer los autos "en relación".

La notificación de la interposición del recurso no suspende los efectos de lo ordenado por la Superintendencia, sin perjuicio de la facultad del tribunal para decretar una orden de no innovar. Las resoluciones que apliquen multa, u ordenen la devolución de sumas de dinero, sólo deberán cumplirse una vez ejecutoriada la sentencia respectiva.

El Superintendente podrá delegar para estos efectos la representación judicial de la Superintendencia. En este caso, las personas en quienes haya recaído tal delegación, prestarán declaraciones ante los tribunales a que se refiere este artículo, mediante informes escritos, los que constituirán presunciones legales acerca de los hechos por ellos personalmente constatados, sin perjuicio de la facultad del tribunal de citarlos a declarar personalmente como medida para mejor resolver.

La Superintendencia estará exenta de la obligación de efectuar consignaciones judiciales.

Artículo 21.- Toda persona beneficiaria de la Ley $\mathrm{N}^{\circ} 18.469$ podrá recurrir ante la Superintendencia frente a cualquier acto u omisión ilegal o arbitrario por parte de Fondo Nacional de Salud que, a su juicio, le provoque privación, perturbación o amenaza de los derechos consagrados en el Régimen de Garantías en Salud. El Superintendente actuará como árbitro arbitrador sin ulterior recurso, sin periuicio de que los beneficiarios puedan optar por recurrir a la Justicia Ordinaria.

El Superintendente, durante el procedimiento, deberá velar por que se respeten la igualdad de condiciones entre los involucrados; la voluntariedad para el beneficiario de retirarse del procedimiento en cualquier momento; la confidencialidad o reserva de todo lo escuchado o visto en el proceso, y la imparcialidad en relación con los participantes.

Sin perjuicio de la facultad del Superintendente de fijar, mediante resolución de general aplicación el procedimiento a seguir en los reclamos que se presenten, una vez que haya tomado conocimiento del reclamo presentado, deberá citar al afectado y a un representante de Fondo Nacional de Salud a una audiencia de conciliación, en la cual el Superintendente ayudará a las partes a buscar una solución a su conflicto obrando como amigable componedor. Las opiniones que emita no lo inhabilitan para seguir conociendo de la causa.

De todo lo obrado en la audiencia se levantará acta, la que, luego de ser leida por los asistentes, será firmada por ellos y por el Superintendente. En caso de existir acuerdo sobre todos o algunos de los puntos sometidos a la 
REVISTA ANALES

Mensaje

decisión del Superintendente, el acta consignará las especificaciones del arreglo, teniendo ésta el carácter de sentencia definitiva respecto del acuerdo.

Articulo 22.- Para el cumplimiento de sus funciones, el Superintendente podrá inspeccionar todas las operaciones, bienes, libros, cuentas, archivos y documentos, sea que obren en poder del Fondo Nacional de Salud o de terceros, y requerir de ellas o de sus jefes superiores, administradores, asesores o personal, los antecedentes y explicaciones que juzgue necesarios para su información. Igualmente, podrá solicitar la entrega de cualquier documento o libro o antecedente que sea necesario para fines de fiscalización, sin alterar el desenvolvimiento normal de las actividades del afectado. Salvo las excepciones autorizadas por la Superintendencia, todos los libros, archivos y documentos de las entidades y personas mencionadas, deberán estar permanentemente disponibles para su examen.

Además, podrá citar a declarar a los jefes superiores, representantes, administradores, asesores y dependientes sea del Fondo Nacional de Salud o de terceros, cuyo conocimiento estime necesario para el cumplimiento de sus funciones.

Artículo 23.- Será facultad de la Superintendencia instruir sumarios administrativos al personal del Fondo Nacional de Salud, en lo referente al cumplimiento del Régimen de Garantías en Salud, sin perjuicio de las facultades que sobre la misma materia tenga el Director de dicho organismo y la Contraloría General de la República.

Asimismo, la Superintendencia podrá aplicar al Director del Fondo Nacional de Salud, cuando éste no diere cumplimiento a las instrucciones o dictámenes por ella emitidos en uso de sus atribuciones legales, previa investigación de los hechos, las sanciones de amonestación, censura o multa. El monto de la multa fluctuará entre 1 a 5 unidades tributarias mensuales y podrá ser reiterada un vez cada 30 días, mientras se mantenga el incumplimiento. De dicha multa, responderá personalmente el infractor.

Párrafo $2^{\circ}$

De la Fiscalización del Régimen de Garantías en Salud a los Beneficiarios de la Ley № 18.933

Artículo 24.- El control y fiscalización del Régimen de Garantias en Salud que se otorga a los beneficiarios de la Ley $\mathrm{N}^{\circ} 18.933$, corresponderá a la Superintendencia de Instituciones de Salud Previsional.

TITULO III

DISPOSICIONES VARIAS

Artículo 25.- Introdúcense las siguientes modificaciones a la Ley $\mathrm{N}^{\circ} 18.469$ :

1.- En el artículo 80:

a) Sustitúyase, al final de la letra b), la expresión ", y" por un punto y coma (;)

b) Sustitúyase, en la letra c), el punto final (.) por la expresión "; y"

c) Agrégase, a continuación de la letra c), la siguiente letra d), nueva:

"d) Las prestaciones comprendidas en el Régimen de Garantias en Salud, en la forma y condiciones que dicho Régimen establezca.".

2.- En el artículo 11:

a) Sustitúyase el inciso primero por el siguiente:

"Las prestaciones comprendidas en el Régimen se otorgarán por los Servicios de Salud, los Establecimientos de Salud de Carácter Experimental, creados por los decretos con fuerza de ley $N^{\circ} 29,30$ y 31, de 2000, del Ministerio de Salud, y los Establecimientos Municipales de Atención Primaria de Salud, sin perjuicio de lo dispuesto en el Régimen de Garantías en Salud."

b) Reemplázase, en el inciso segundo, las palabras: "los Servicios de Salud" por "dichos organismos". 
Mensaje

c) Suprímase el inciso cuarto, pasando el actual inciso quinto a ser cuarto.

3.- Sustitúyase, en el inciso $3^{\circ} \mathrm{del}$ artículo 13, la frase "Estas prestaciones", por la oración: "Sin perjuicio de lo dispuesto en el Régimen de Garantías en Salud, estas prestaciones".

4.- En el artículo 25:

a) Sustitúyase, en el inciso primero, la frase "el Decreto con Fuerza de Ley $N^{\circ} 3$, de 1981, del Ministerio de Salud" por la siguiente: "la Ley $\mathrm{N}^{\circ} 18.933$ ".

b) Reemplázase el inciso segundo, por el siguiente:

"Dichas Instituciones estarán obligadas a otorgar, como mínimo, el Régimen de Garantías en Salud, sin perjuicio de las demás prestaciones y beneficios que se estipulen en los contratos que celebren con sus afiliados y de los que se establecen en la Ley $\mathrm{N}^{\circ} 18.933 . "$.

c) Derógase el inciso tercero.

5.- Agrégase, en el artículo 28, a continuación de la expresión "se indican", la siguiente frase, precedida por una coma (.): "sin perjuicio de las normas específicas que, al respecto, establezca el Régimen de Garantias en Salud."; pasando el punto seguido (.) a ser punto aparte, y el párrafo final a ser inciso segundo, nuevo.

Artículo 26.-Introdúcense las siguientes modificaciones a la Ley $\mathrm{N}^{\circ} 18.933$ :

1.- En el artículo $2^{2}$ :

a) Sustitúyase, al final de la letra g), la expresión ", y" por un punto y coma (:).

b) Sustitúyase, en la letra h), el punto final (.) por un punto y coma (;).

c) Agréganse, a continuación de la letra h), las siguientes letras i) y j), nuevas

"i) La expresión "plan convenido" o "plan" incluye el Régimen de Garantías en Salud a que se refiere el artículo 33 bis y el plan complementario establecido en la letra a) del artículo 33.

j) La expresión "prestadores" corresponde a cualquier persona natural, establecimiento o institución cuya actividad esté relacionada con la atención de salud, tales como: consulta, consultorio, hospital, clínica, centro médico, centro de diagnóstico terapéutico, centro de referencia de salud, laboratorio y otros de cualquier naturaleza, incluyendo ambulancias y otros vehículos adaptados para atención extrahospitalaria.".

2.- En el artículo $3^{\circ}$ :

a) Intercálase, en el numeral 9), a continuación del inciso primero, el siguiente inciso segundo, nuevo, pasando el actual a ser tercero:

"La misma facultad podrá ejercer la Superintendencia respecto de los convenios a que se refiere el inciso segundo de la letra a bis), del artículo 33, correspondiéndole especialmente velar porque éstos se ajusten a las obligaciones que establece la presente ley y aquellas que emanan de los contratos de salud previsional respectivos.".

b) Agrégase, a continuación del numeral 13), el siguiente numerando 14, nuevo:

"14) Requerir de los prestadores a que se refiere la letra a bis), del artículo 33, la información que acredite el cumplimiento de las normas sobre acceso, oportunidad y calidad de las prestaciones y beneficios de salud que se otorguen a los beneficiarios, sin perjuicio de las facultades que pudieren corresponder a otros organismos.".

3.- En el artículo 33:

a) Reemplázase la letra a), por la siguiente:

"a) Plan complementario al Régimen de Garantías en Salud a que se refiere el artículo 33 bis, si se hubiere 
REVISTA ANALES

Mensaje

pactado, incluyendo porcentajes de cobertura y valores sobre los cuales se aplicarán."

b) Intercálase, a continuación de la letra a), la siguiente letra a bis), nueva:

"a bis) La individualización de los prestadores contemplados, en cualquier forma en el contrato, con indicación precisa de las prestaciones y beneficios que se otorgarán a través de ellos y de los procedimientos y requisitos para acceder a los mismos

Los convenios entre las instituciones y los prestadores relativos a las condiciones definidas o pactadas para el otorgamiento de las prestaciones y beneficios bajo la modalidad a que se refiere el inciso anterior, deberán constar por escrito y mantenerse a disposición de la Superintendencia.".

c) Sustitúyase la letra c), por la siguiente:

"c) Mecanismos para el otorgamiento de todas las prestaciones y beneficios que norma esta ley y de aquellos que se estipulen en el contrato.".

d) Modificase la letra d) del siguiente modo:

i) Sustitúyase, en el inciso primero, la primera oración que termina con la palabra "anuales", por la siguiente "Precio del Régimen de Garantías en Salud a que se refiere el artículo 33 bis y precio del plan complementario acordado en conformidad a lo dispuesto en la letra a) de este artículo: la unidad en que se pactarán, señalándose que los precios expresados en dicha unidad sólo podrán variar una vez cumplidos los respectivos períodos anuales, sin perjuicio de lo dispuesto en el inciso tercero del artículo 38.".

ii) Intercálase, en el inciso segundo, a continuación de la frase "las Instituciones de Salud Previsional podrán vender planes", la palabra: "complementarios".

e) Sustitúyase, en las letras e), f) y g), la expresión "artículo 33 bis" por "artículo 33 ter", toda las veces que all aparece.

f) Reemplázase, en el inciso tercero, la oración que sigue a continuación del punto seguido, por la siguiente: "E precio del plan deberá pactarse en unidades de fomento o en moneda de curso legal en el país; tratándose de los contratos que se celebren con arreglo al artículo 39, el precio también podrá expresarse en el porcentaje equivalente a la cotización legal de salud.".

4.-Intercálase, a continuación del artículo 33, el siguiente artículo 33 bis, nuevo, pasando el actual a ser artículo 33 ter:

"Artículo 33 bis.- Sin perjuicio de lo dispuesto en el artículo anterior, las Instituciones de Salud Previsional estarán obligadas, respecto de sus beneficiarios, a otorgar el Régimen de Garantías en Salud.

Los procedimientos y mecanismos para el otorgamiento del referido Régimen, serán sometidos por las Isapres al conocimiento de la Superintendencia para su aprobación.

En todo caso, las modificaciones que se le introduzcan al Régimen de Garantías en Salud deberán entrar en vigencia, para todos los beneficiarios, en el plazo que establezca el decreto respectivo, no pudiendo supeditarse su aplicación al ejercicio de la facultad que se establece en el inciso tercero, del artículo 38

Al otorgamiento de los beneficios a que se refiere este artículo, no le será aplicable lo dispuesto en las letras e), f) y g) del artículo 33, salvo en cuanto a que podrá convenirse la exclusión de las prestaciones cubiertas por otras leyes, hasta el monto de lo cubierto.

El precio del Régimen de Garantías en Salud será el mismo para todos los beneficiarios de la Isapre, sin que pueda aplicarse para su determinación la relación de precios por sexo y edad prevista en el contrato. Para dicho efecto, las instituciones podrán contar con mecanismos de redistribución de los recursos provenientes de cotizaciones."

5.- En el artículo 38:

a) Modificase el inciso segundo del siguiente modo: 
Mensaje

i) Reemplázase la frase "una vez transcurrido un año de vigencia de beneficios contractuales" por la siguiente: "una vez transcurridos tres años de vigencia de beneficios contractuales.".

ii) Sustitúyase la palabra "primer" por la siguiente: "tercer".

iii) Reemplázase, en la última oración, la expresión "tiempo determinado" por la siguiente: "tiempo superior".

b) Sustitúyase, en el inciso tercero, la oración "Anualmente, en el mes de suscripción del contrato, las instituciones podrán revisar los contratos de salud que correspondan", por la que siguiente: "Una vez transcurridos tres años desde la suscripción del contrato, anualmente y en el mes de suscripción, las instituciones podrán revisar los contratos de salud que correspondan".

Artículo 27.- Sin perjuicio de lo establecido en el Régimen de Garantías en Salud, las prestaciones de saluo relativas a la atención médica curativa, establecidas en las siguientes normas legales, mantendrán su vigencia: ley № 6.174, de Medicina Preventiva, trabajadores acogidos a reposo preventivo; ley № 18.948; ley № 19.086; ley № 19.123; ley № 19.779; decreto ley № 1.757, de 1977; decreto ley № 1.772, de 1977; y decreto ley № 2.859, de 1979.

\section{DISPOSICIONES TRANSITORIAS}

Artículo primero.- Facúltase al Presidente de la República por el plazo de un año, contado desde la fecha de publicación de la presente ley, para regular, mediante uno o más decretos con fuerza de ley expedidos por intermedio del Ministerio de Salud, los que también deberán ser suscritos por el Ministro de Hacienda, la Superintendencia de Garantías en Salud, creada en la presente ley.

El Presidente de la República, en el ejercicio de las facultades que se le delegan, deberá dictar las normas necesarias para el adecuado funcionamiento del organismo a que se refiere el inciso anterior, para lo cual deberá, entre otras materias, regular lo relativo a:

1.- Responsabilidad del Jefe Superior del servicio y demás jefaturas por el ogro de los resultados y el eficiente empleo de los recursos.

2.- Establecimiento de niveles de dirección y gerencia adecuados a una eficiente gestión.

Sin perjuicio de la potestad del Jefe Superior para organizar internamente al servicio, se deberán establecer las bases de la organización del referido organismo, las que deberán consultar criterios de flexibilidad en su estructura y funcionamiento.

3.- Definición de las atribuciones que le corresponderán al Jefe Superior para el mejor cumplimiento de sus fines.

4.- Régimen de administración de personal aplicable a todos los trabajadares del organismo, el que podrá ser diferente en atención a los estamentos y las funciones involucrados, y fijación de las dotaciones correspondientes.

5.- Sistemas de remuneraciones aplicables a los trabajadores, los cuales deberán consultar en todo caso, incentivos económicos o de otra naturaleza asociados al desempeño individual y logro de metas por unidades de gestión e institucionales.

6.- Obtención y administración de recursos financieros, físicos y materiales, sujetándose en todo caso a las normas legales de aplicación general sobre la materia.

7.- Mecanismos de adquisiciones y administración de bienes y servicios.

8. Facultades de celebración de convenios relativos al objeto y naturaleza del organismo.

9.- Regulaciones para incorporar al servicio a que se refiere este artículo, sersonal y recursos provenientes de otras reparticiones públicas, incluidas las establecidas en el decreto ley № 2.763, de 1979.

10.- Facultades para ordenar la devolución, en todo o parte, de lo pagado por el otorgamiento de prestaciones, cuando éstas se hayan otorgado sin cumplir las garantías de acceso, oportunidad y calidad definidas por el Régimen de Garantias en Salud. 
REVISTA ANALES

Mensaje

El mayor gasto que represente la aplicación de este artículo se financiará con cargo al Presupuesto del Ministerio de Salud.

Artículo segundo.- El primer Régimen de Garantias en Salud deberá promulgarse, a más tardar, el último día del tercer mes siguiente a la publicación en el Diario Oficial, del reglamento del Consejo Consultivo del Régimen. Con todo, el reglamento del referido Consejo será publicado una vez que haya entrado en vigencia el decreto con fuerza de ley a que se refiere el artículo precedente.

El Régimen de que trata este artículo, comenzará a regir a contar del primer día del cuarto mes siguiente a su publicación.

Los contratos de salud previsional que se celebren con posterioridad a la entrada en vigencia del referido Régimen, deberán ajustarse a él. Los contratos celebrados con anterioridad, se ajustarán a sus disposiciones en sus respectivas anualidades.

Artículo tercero.- Sin perjuicio de lo dispuesto en el artículo $9^{\circ}$ de la presente ley, el Presidente de la República, a momento de designar los miembros del primer Consejo Consultivo del Régimen de Garantías en Salud, determinará cinco consejeros que permanecerán tres años en sus cargos.".

Dios guarde a V.E.

RICARDO LAGOS ESCOBAR

Presidente de la República

OSVALDO ARTAZA BARRIOS

Ministro de Salud

NICOLÁS EYZAGUIRRE GUZMÁN

Ministro de Hacienda 


\section{INFORME DE INFLUENZA. SEMANA 1 A 52 DE $2010^{33}$}

Quizás por su magnitud, el terremoto y maremoto del 27 de febrero de 2010 opaca en la memoria el brote de influenza que la OMS declaró como alerta pandémica. Ya en agosto de 2009 se decía que se esperaba que el virus de la influenza A(H1N1) se comportase "de ahora en adelante, como un virus estacional, que continuará circulando en los próximos años. En el periodo postpandémico se seguirán observando brotes localizados de distinta magnitud". La forma de presentar los informes, si los comparamos con las notas médicas del siglo XIX o las memorias de las instituciones de salud de principios del siglo XX, difiere notablemente. Por un lado, la cobertura de los datos a nivel país habla de una red de salud pública que aún mantiene el control de los mismos. De otro lado, se observa el uso de gráficas para apreciar visualmente la cantidad de casos y muertes con el objeto de tomar el pulso a la situación. Pueden considerarse dichos informes como una nueva forma de controlar el miedo o de producirlo, un tipo de reporte que hoy hacemos parte de nuestra cotidianeidad normalizando, en cierta forma, las noticias sobre el número de muertos, invisibles en sus historias, nombres y cuerpos bajo la forma del número.

Los ciclos descritos en este dossier acá vuelven a repetirse: catástrofe natural, epidemia, movimientos sociales, pues el año 2011 será recordado por las grandes protestas por la educación gratuita.

33. Ministerio de Salud de Chile, Informe de Influenza. Semana 1 a 52 de 2010. Disponible en: https:// www.minsal.cl/portal/url/item/be2362fd14216ef1e040010164011397.pdf 


\section{Informe de Influenza}

\section{Semana 1 a 52 de 2010}

El martes 10 de agosto, la Directora General de la Organización Mundial de la Salud, declaró que el mundo ya no estaba en fase 6 de alerta pandémica y que se pasaba al período postpandémico. Señaló también, que se espera que el virus de la influenza $A(H 1 N 1) 2009$ se comporte, de ahora en adelante, como un virus estacional, que continuará circulando en los próximos años. En el período postpandémico se seguirán observando brotes localizados de distinta magnitud.

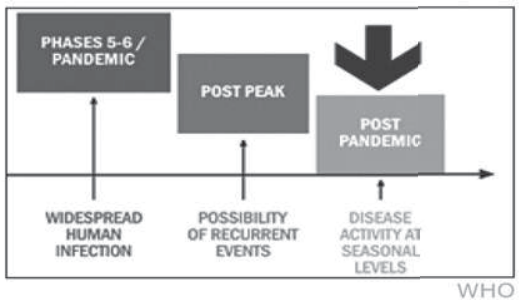

En Chile, se observó un aumento de las consultas respiratorias a partir de la semana 31, con una co-circulación de influenza A (H1N1) 2009 y H3N2; esta última, triplicando a la influenza pandémica. Asimismo, la influenza B comenzó a aumentar la semana 31, con una tendencia actual al descenso sostenido.

\section{Síntesis situación 2010}

La tasa acumulada de casos de ETI el año 2010 fue inferior a la del año 2009 (693 por $10^{5}$ habitantes y 1.050 por $10^{5}$ habitantes respectivamente). A diferencia del año anterior, el máximo se alcanzó la semana 37 (fines de septiembre), mientras que en 2009, el máximo fue en la semana 28. Un hecho similar se registró el 2002, donde el brote estacional se presentó en forma tardía, con un máximo en la semana 33, cuando circuló principalmente Influenza $A(H 1)$ e Influenza $B$, igual situación que el año 2010. En los centros centinela de influenza la positividad fue de 19,7\% para influenza, con un máximo la SE 35 (41\%).

El porcentaje de consultas por causas respiratorias en los servicios de urgencia alcanzó un máximo la semana 36 con un $43 \%$ de las consultas totales, debidas principalmente, a consultas por IRA alta e influenza. Desde la semana 37 se observa una disminución, llegando la semana $52^{1}$ a un 18\%. En relación a las hospitalizaciones por causas respiratorias se observó un máximo la semana 28 (29\%) asociada al aumento de Virus Respiratorio Sincial (VRS) y posteriormente un nuevo incremento en la semana 37 (31\%), que coincide con el aumento de Influenza.

Durante el año 2010 (SE 52) se confirmaron 310 casos de IRA grave por influenza H1N1 (2009) con una tasa de 1,8 por cien mil habitantes. Se observó un aumento en el número de casos desde la semana 26, llegando a un máximo en la semana 35. Además, en la semana 31 se observó un aumento de casos IRA grave por influenza A (H3N2), superando en la semana 33 el número de casos confirmados en relación a Influenza H1N1 (2009), alcanzando el máximo las semanas 35 y 36. Durante el año 2010 se confirmó un total de 868 casos de influenza A (H3N2). Se confirmaron 55 casos de IRA grave por influenza B. En el 57,3\% de los casos de IRA Grave, existió el antecedente de enfermedad de base

Respecto a los fallecidos, se registraron 81 defunciones asociadas a influenza: 21 por Influenza H1N1 (2009); 57 asociadas a influenza A (H3N2) y 3 defunciones asociadas a influenza B.

El 29,4\% de las muestras analizadas resultó positiva a algún virus: $51 \%$ VRS, 22\% influenza A (H3N2), 11,7\% parainfluenza; 3,4\% influenza B e influenza A(H1N1) 2009, sólo representa un 4\%.

\footnotetext{
${ }^{1}$ Información disponible al 5/1/2011
} 
1.- Tendencia e intensidad de la actividad de enfermedad respiratoria: Enfermedad Tipo Influenza (ETI) en centros centinelas ambulatorios.

Desde la semana epidemiológica 32 (que termina el 14 de agosto), se observa un incremento de casos de ETI, llegando a un máximo en la semana 37 ( tercera semana de septiembre): 80 casos por 100.000 habitantes con intensidad elevada. La tasa a la semana 52 es de 1,1 por 100.000 habitantes, cifra esperada para esta época del año. La tasa acumulada a nivel nacional fue de 693 por 100.000 habitantes, inferior en un 34,4\%, respecto a la tasa acumulada de 2009 (1.050 por 100.000 habitantes).

Durante el 2010, en los centros centinela ambulatorios se tomaron muestras a 1.607 casos de ETI notificados, confirmándose 268 casos de influenza A y 22 de Influenza B ( 19,7\% positividad para influenza). El máximo de positividad a influenza se observó la semana 35 (41\%).

El aumento estacional observado el 2010 se desplazó a los meses de agosto-septiembre. Una situación similar se registró el 2002, donde el brote estacional se presentó en forma tardía, con un máximo en la semana 33, cuando circuló principalmente Influenza A(H1) e Influenza B.
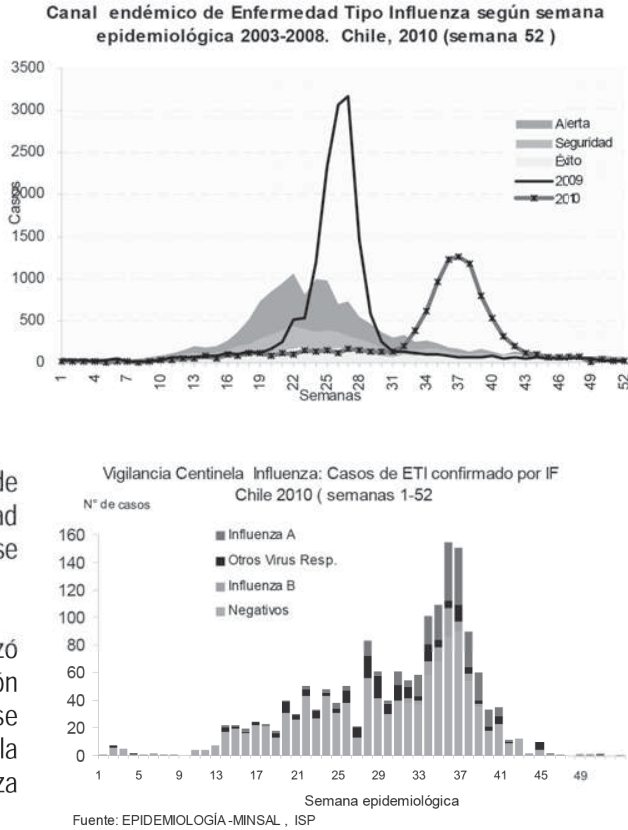

\section{2.- Monitoreo de Atenciones por Causas Respiratorias en Servicios de Urgencia Hospitalaria}

Según la información proporcionada por el DEIS - MINSAL, el porcentaje de consultas por causas respiratorias en los servicios de urgencia alcanzó un máximo en la semana 36 con un $43 \%$ de las consultas totales, debidas principalmente, a consultas por IRA alta e influenza. Desde la semana 37 se observa una disminución, llegando la semana $52^{2}$ a un $18 \%$.

En relación a las hospitalizaciones por causas respiratorias se observó un aumento con un máximo en la semana 28 $(28,8 \%)$ asociada al aumento de Virus Respiratorio Sincial (VRS) y posteriormente un nuevo incremento en la semana $37(30,7 \%)$, que coincide con el aumento de Influenza.

En los menores de 15 años, el máximo se alcanzó en la semana 37, con un 59,9\% del total de consultas, sin embargo, en la semana 28 alcanzo 55,6\% asociado a detección de VRS. En adultos, el valor máximo de las

\footnotetext{
${ }^{2}$ Información disponible al 5/1/2011
} 
consultas por causas respiratoria llegó sólo a un 30\%, en la semana 38. En ambos casos, es inferior al máximo observado en el 2009.
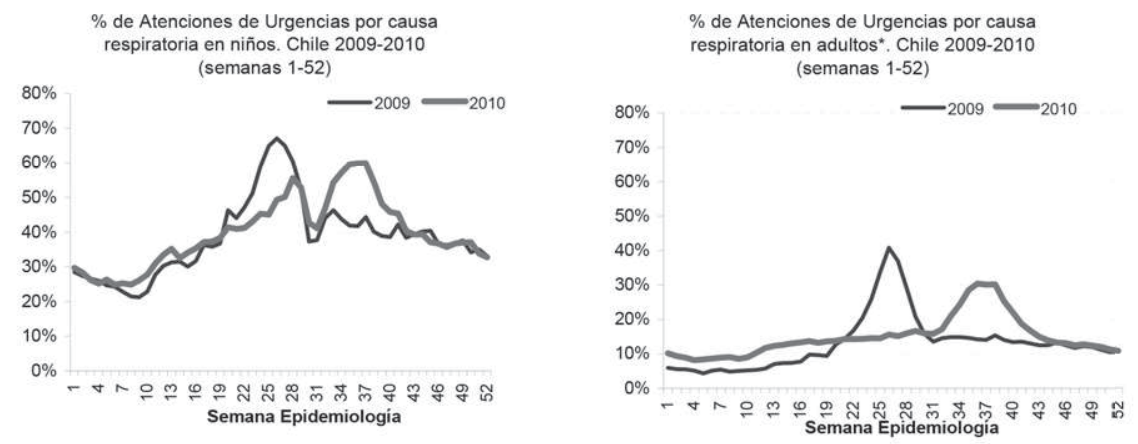

Según diagnóstico específico, en las atenciones por influenza el máximo se observó en la semana 36, con un 7\% del total de consultas. En los menores de 15 años , correspondió a un $9 \%$ en relación a los otros grupos de edad.

Posteriormente, disminuye en todas las edades llegando la semana 52, a 0,4\% del total de consultas de urgencia.

En relación a las consultas por neumonia, presentaron un incremento a partir de la semana 21, con un máximo discreto en la semana 28 (2,8\%). En los menores de 15 años, el máximo se observó la semana 28, con un 4,5\% del total de consultas, lo que coincide con la mayor circulación de Virus Respiratorio Sincial. Posteriormente se observa un aumento sostenido en el grupo de 65 y más años, que llega a un máximo en la semana 39 (8\%).
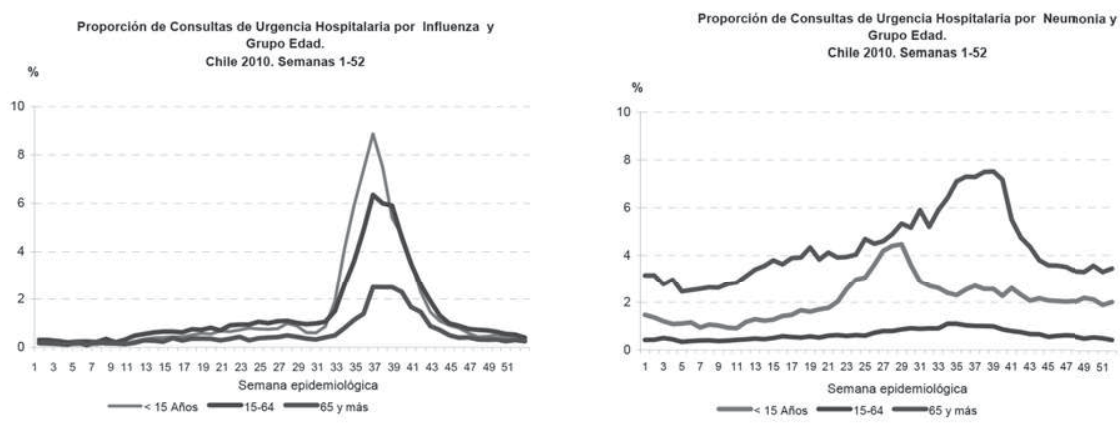


\section{3.- Casos de IRA Grave confirmados}

Durante el año 2010 (SE 52) se confirmaron 310 casos de IRA grave por influenza H1N1 (2009) en Chile (1,8 por cien mil habitantes). Se observó un aumento en el número de casos desde la semana 26, llegando a un máximo en la semana 35. La tasa más alta se presentó en la Región de Los Ríos (24 por cien mil), seguida de la Región de Aysén (6,7 por cien mil). En las Regiones de Tarapacá y Magallanes no se confirmaron casos de IRA grave por virus H1N1 (2009). Las mujeres presentaron igual tasa que los hombres (1,8 por cien mil habitantes). El mayor riesgo por edad lo presentan los menores de un año, seguido del grupo entre 1 a 4 años.

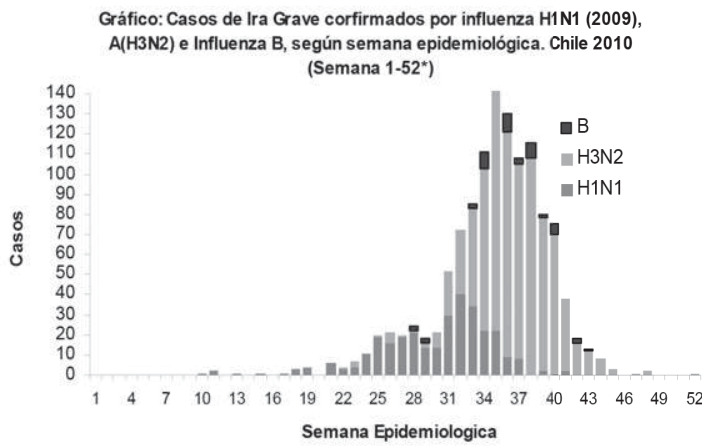

Además, en la semana 31 se observó un aumento de casos IRA grave por influenza A (H3N2), superando en la semana 33 el número de casos confirmados en relación a Influenza H1N1 (2009), alcanzando el máximo las semanas 35 y 36. Durante el año 2010 se confirmó un total de 868 casos de influenza A (H3N2) y la tasa más alta correspondió a la Región de Los Ríos $(25,1$ por cien mil habitantes) y Región Metropolitana (tasa 18,6 por cien mil). La tasa por edad muestra mayor riesgo en edades extremas: menores de 1 año y mayores de 60 años. Se confirmaron 55 casos de IRA grave por influenza B. Del total de IRAG, en el $57,3 \%$ de los casos existió el antecedente de enfermedad de base.

\section{4.- Casos fallecidos.}

A la semana 52 de 2010, se registraron 81 defunciones asociadas a influenza: 21 por Influenza H1N1 (2009); 57 asociadas a influenza A (H3N2) y 3 defunciones asociadas a influenza B.

El 65,4\% de los casos fallecidos por influenza correspondió a mayores de 60 años, y se observó mayor cantidad de casos asociados a Influenza A (H3N2). El 83,8\% de los casos fallecidos presentaban alguna enfermedad de base.

Distribución de casos de IRA Grave H1N1 (2009), Influenza A(H3N2) e Influenza B según grupos de edad. Chile, semanas 1- 52 de 2010

\begin{tabular}{|c|c|c|c|c|c|c|}
\hline Grupo de edad & $<1$ años & $\begin{array}{l}1-4 \\
\text { años }\end{array}$ & 5 - 14 años & $\begin{array}{c}15-29 \\
\text { años }\end{array}$ & $\begin{array}{c}30-59 \\
\text { años }\end{array}$ & $\begin{array}{l}60 \text { y } \\
\text { más } \\
\text { años }\end{array}$ \\
\hline$N^{0}$ de casos H1N1(2009) & 41 & 42 & 25 & 34 & 122 & 46 \\
\hline $\begin{array}{l}\text { Tasa por grupo de edad por } \\
100.000 \text { hbtes }\end{array}$ & 16,3 & 4,2 & 1,0 & 0,8 & 1,8 & 2,0 \\
\hline $\begin{array}{c}\mathrm{N}^{\circ} \text { de casos Influenza } \\
\mathrm{A}(\mathrm{H} 3 \mathrm{~N} 2)\end{array}$ & 143 & 148 & 63 & 36 & 118 & 360 \\
\hline $\begin{array}{c}\text { Tasa por grupo de edad por } \\
100.000 \text { hbtes }\end{array}$ & 56,7 & 14,9 & 2,5 & 0,8 & 1,7 & 14,7 \\
\hline NN de casos Influenza B & 8 & 14 & 12 & 6 & 6 & 9 \\
\hline $\begin{array}{c}\text { Tasa por grupo de edad por } \\
100.000 \text { hbtes }\end{array}$ & 3,2 & 1,4 & 0,5 & 0,1 & 0,1 & 0,4 \\
\hline
\end{tabular}




\section{5.- Circulación viral}

El año 2009, se procesó en la red de vigilancia un total de 51.408 muestras, de las cuales, el $34 \%$ tuvo un resultado positivo a algún virus respiratorio y de esas positivas, el 23\% correspondió a influenza pandémica. El año 2010, el 7,4\% de las muestras positivas han sido influenza A (H1N1) 2009 y el 12\% influenza A H3N2.

El año 2010 (a SE 52), se procesaron 34.431 muestras, de las cuales, el 29,4\% resultó positiva a algún virus respiratorio. El 51\% correspondió a VRS, 22\% influenza A (H3N2), 11,7\% parainfluenza. La influenza A(H1N1) 2009, sólo representa un $4 \%$ y la intluenza B, un 3,4\%.

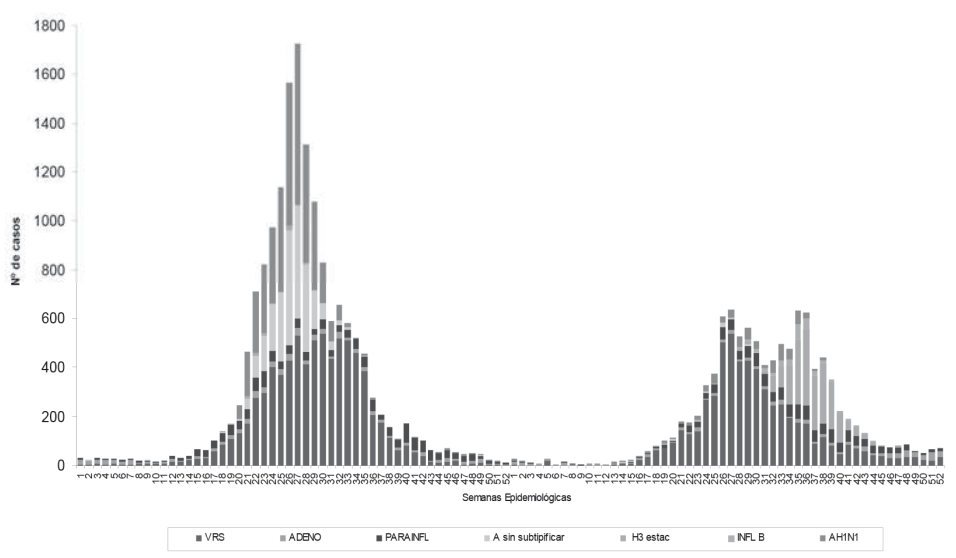

De acuerdo a grupos de edad, los más afectados por el VRS fueron los menores de 1 año, lo mismo que con el adenovirus. El virus influenza A H3N2 afectó especialmente al menor de 1 año, de 1 a 4 y de 65 y más, comportamiento similar a la influenza B. El virus de la influenza A H1N1 mostró una gradiente descendente por grupos de edad, afectando más a los menores de 1 año (tasa de 16 por cien mil hbte).

Tasa de circulación viral por grupos de edad. Chile, 2010.

\begin{tabular}{|lcccccc|}
\hline & Menor 1 año & 01_04_años & 05_14_años & 15_54_años & _55_64_años _65_y_mas \\
\hline VRS & 1401,5 & 149,0 & 4,4 & 0,3 & 1,1 & 1,6 \\
H3N2 & 44,5 & 19,4 & 3,2 & 1,2 & 3,3 & 13,0 \\
H1N1 & 16,0 & 5,8 & 2,3 & 2,0 & 1,9 & 1,3 \\
B & 17,6 & 6,5 & 4,7 & 0,6 & 0,5 & 2,9 \\
Parainfluenza & 279,6 & 37,0 & 2,7 & 0,2 & 0,5 & 1,4 \\
Adenovirus & 90,5 & 25,9 & 2,1 & 0,0 & 0,1 & 0,1 \\
\hline
\end{tabular}


MINISTERIO DE SALUD DE CHILE

La información reportada por la Red de Vigilancia Metropolitana de la Universidad Católica de Chile, de la Universidad del Desarrollo e Integramédica ${ }^{3}$, muestra que en la SE 52, el virus que prevalece es el adenovirus.

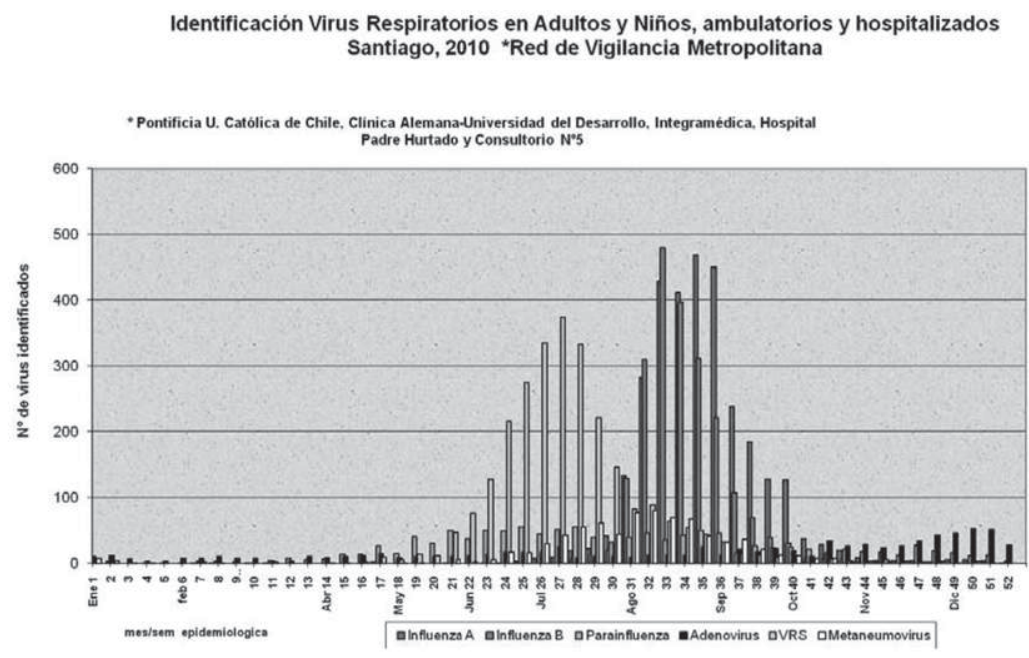

\section{Entrega de antivirales}

Hasta la semana 52 se ha entregado un total de 47.270 tratamientos antivirales ${ }^{4}: 27.254$ tratamientos Oseltamivir en cápsulas, 19.048 Oseltamivir jarabe y 968 tratamientos de Zanamivir.

Del total de tratamientos administrados, el $33 \%$ se ha entregado a menores de 5 años y el $30,2 \%$, a personas de 15 a 49 años. El 82,7\% (39.074) de los tratamientos se entregó en establecimientos del sector público.

En la SE 32 se incrementó la entrega de tratamientos antivirales, tanto en el sector público como en el privado, registrándose en la SE 38 el máximo de entrega de AV (6.303 tratamientos).

\footnotetext{
${ }^{3}$ http://virus.med.puc.cl/virus_respiratorios/bienvenida.html

${ }^{4}$ Segün la norma clínica vigente (www.pandemia.cl), el tratmiento antiviral es gratuito para las personas que cumplan con el cuadro clínico de Influenza y presenten condiciones de riesgo para enfermedad respiratoria.
} 


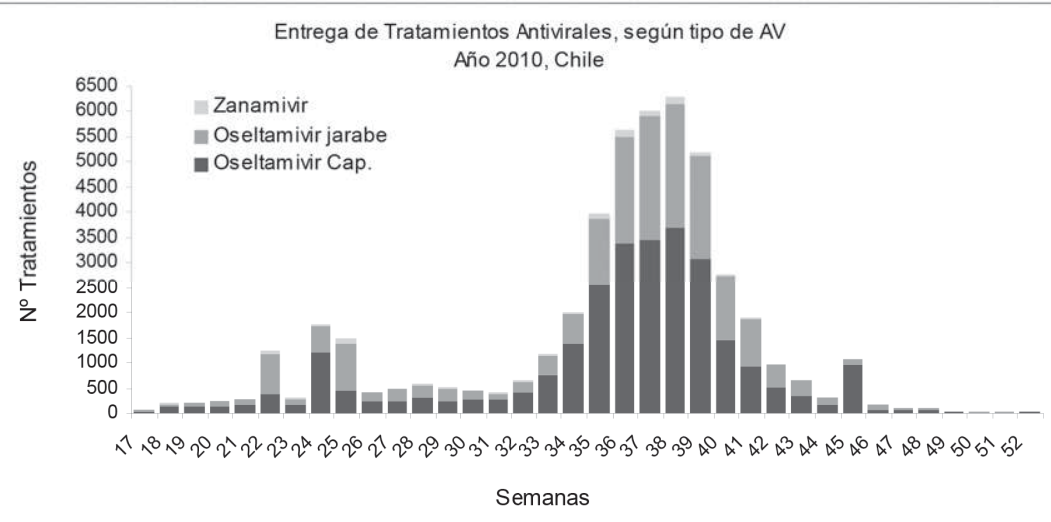

\section{6.- Situación Internacional}

El último informe disponible en la web de la OMS, corresponde a la actualización del día 04 de enero 2011. En América del Norte (Canadá y Estados Unidos), la actividad gripal se mantuvo baja; en Canadá, predominó la influenza A/H3, mientras que en Estados Unidos, ha habido co-circulación de la influenza A y B. En México, en la SE 49 , de todas las muestras analizadas, el porcentaje de muestras positivas para la influenza fue de $38 \%$. Desde la SE 30 ha predominado la Influenza $\mathrm{A} / \mathrm{H} 3$.

La actividad gripal en América Central y América del Sur continuó siendo baja. En la Región de las Américas hay cocirculación de virus de Influenza B y A/H3.

En Estados Unidos en la SE 51, la proporción de consultas por síndromes gripales superó la línea basal. La proporción de muertes atribuidas a neumonía e influenza se encontraba en el umbral epidémico y esta semana se reportó una muerte pediátrica asociada a gripe A/H3. Durante la SE 51 , el $21 \%$ de las muestras analizadas fueron positivas para la influenza: influenza A (40,2\%); influenza B $(30,5 \%)$ y A/H3 la influenza $(27,1 \%)$.

En Cuba, el VRS sigue predominando entre la SE 47-50. Entre los virus de la influenza, la gripe A/H3 fue el virus predominante. En República Dominicana, en la SE 50, de todas las muestras analizadas, el porcentaje de muestras positivas para el virus de la gripe fue de 11\%. Esta semana se detectaron VRS y adenovirus. En Costa Rica, a partir de la SE 42-51, el virus de la gripe predominante que circula es influenza tipo B. Un pequeño número de adenovirus y VRS siguió siendo detectado. En Honduras, en la SE 51, muy pocas muestras dieron positivo para virus respiratorios. En Bolivia, el virus de la gripe circulante, predominante fue $\mathrm{A} / \mathrm{H} 3$, especialmente en la parte oriental del país. En Paraguay, en la SE 51, el único virus respiratorio detectado fue A/H3, que ha predominado desde SE 41. La proporción de muestras positivas para la influenza mostró una tendencia ascendente desde la SE 42.

De acuerdo al informe de la Vigilancia Epidemiológica de Europa, en la semana 52/2010, 15 de los 25 países informaron una tendencia creciente de la actividad de influenza. El porcentaje de muestras centinelas que resultaron positivas para influenza en la SE 52, es de $46 \%$, indicando un aumento en la intensidad. Al combinar muestras positivas de centinelas y no centinelas, el $73 \%$ fueron tipo A y $27 \%$ tipo B. El $98 \%$ de la influenza A fue A(H1N1) 
MINISTERIO DE SALUD DE CHILE

2009. La semana 52, seis países informaron 56 IRAG, de las cuales, 22 fueron por virus A(H1N1) 2009. De las 613 IRAG reportadas desde la semana 40, 20 han fallecido.

Mapa de Intensidad Actividad Influenza SE 52

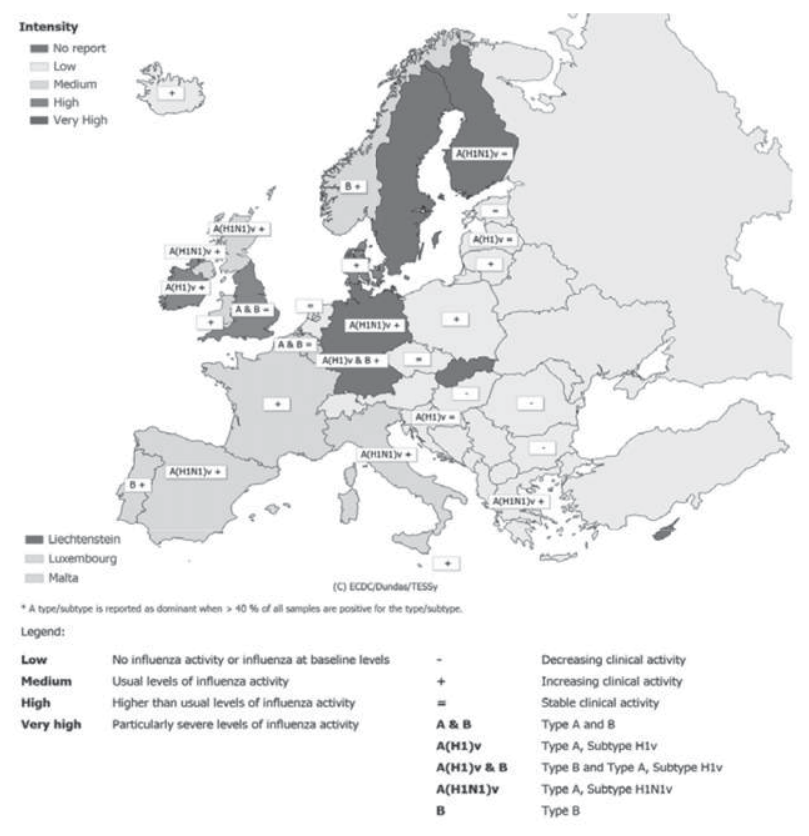




\section{Recomendaciones de la OMS a las autoridades nacionales durante el periodo post-pandémico}

Monitoreo de las enfermedades respiratorias

La OMS recomienda que durante el periodo post-pandémico la vigilancia comprenda lo siguiente:

- monitoreo de eventos inusuales tales como la aparición de conglomerados de morbilidad o mortalidad por enfermedades respiratorias graves;

- investigación de los casos, conglomerados o brotes graves o inusuales para acelerar la identificación de cambios importantes de la epidemiología o la gravedad de la gripe:

- mantenimiento de la vigilancia sistemática, en particular de las enfermedades de tipo gripal y los casos de infecciones respiratorias agudas graves;

- mantenimiento de la utilización de los canales de transmisión sistemática de datos tales como FlulD, FluNet, y EUROFlu, para transmitir datos obtenidos en la vigilancia sistemática de las enfermedades respiratorias;

- notificación inmediata a la OMS (incluida, cuando proceda, la notificación en virtud del Reglamento Sanitario Internacional) si se detectan algunos de los cambios siguientes:

- transmisión persistente de gripe H1N1 2009 resistente a los antivirales

- casos humanos de infección por cualquier virus gripal que no circule actualmente entre las poblaciones humanas

- todo cambio notable de la gravedad o de otra característica epidemiológica o clínica del virus H1N1 2009, en particular los cambios que afecten a la distribución por edades, las manifestaciones clínicas o la proporción de casos que exijan un tratamiento intensivo, o un aumento imprevisto del número de casos;

- monitoreo del virus H1N1 2009 para detectar cambios genéticos, antigénicos o funcionales importantes tales como los que determinan la sensibilidad a los fármacos antivirales.

\section{Vacunación}

La vacunación sigue siendo un arma importante para disminuir la morbilidad y mortalidad causadas por los virus gripales. La OMS recomienda decididamente la vacunación de las personas con alto riesgo en los países que disponen de vacunas antigripales.

El virus gripal H1N1, causante de la pandemia de 2009, sigue circulando en algunas partes del mundo y es responsable de brotes y de morbilidad en diversos grados. [n algunos países, se dispone de vacunas trivalentes[1] contra la gripe estacional que incluyen el virus II1N1 (2009). [n otros, sin embargo, no se dispone de vacuna contra la gripe estacional. La OMS opina que sigue siendo de interés para la salud pública el uso de vacunas monovalentes contra el H1N1 (donde se disponga de ellas) para inmunizar a las personas con riesgo de enfermar gravemente por causa de una infección gripal por H1N1, en especial donde no se dispone de vacuna trivalente contra la gripe estacional.

Las vacunas monovalentes contra la gripe por H1N1 se deberían utilizar según las directrices de las autoridades nacionales de reglamentación. La OMS seguirá solicitando consejo al Grupo de Expertos de Asesoramiento Estratégico (SAGE) según evolucione la situación.

\section{Manejo clínico}

Las personas que presuntamente hayan contraído la gripe deben recibir una atención clínica apropiada. A esos efectos, se encontrarán orientaciones en las directrices de la OMS para el manejo clínico, que se refieren tanto a la gripe estacional como a la pandémica. Se prevé que el virus H1N1 (2009) seguirá circulando durante algunos años en forma de virus estacional. Es probable que se registren casos graves entre las personas con alto riesgo, as como entre otras personas por lo demás en buen estado de salud. Sigue siendo importante que esos casos se detecten rápidamente y se traten de forma apropiada. Deben seguir aplicándose las directrices de la OMS para el uso de medicamentos antivirales, que se refieren a la gripe estacional y a la pandémica.

En los grupos de mayor riesgo de contraer una enfermedad grave por causa del virus pandémico H1N1 figuraban los niños pequeños, las mujeres embarazadas, y las personas con afecciones respiratorias u otras afecciones crónicas, en particular asma y diabetes. Los pacientes con gripe grave 0 cuyo estado clínico empiece a deteriorarse deberían ser tratados con oseltamivir lo antes posible Los pacientes con riesgo elevado de sufrir una gripe grave o complicada deberían ser tratados con oseltamivir o zanamivir lo antes posible. 


\section{Anexo 1: Canales endémicos de Enfermedad Tipo Influenza (ETI) en Consultorios Centinela Chile, 2009 semanas 1- 52 de 2010.}

Arica: Desde la semana 24 se observa una tendencia al alza, con variaciones posteriores y un máximo en la semana 31 (14,5/100.000). Entre las SE 34 y 39 se han detectado casos de influenza A y nuevamente en la semana 39 .

En el 2009, el máximo se alcanzó en la SE 28 (106/100.000 hab.).

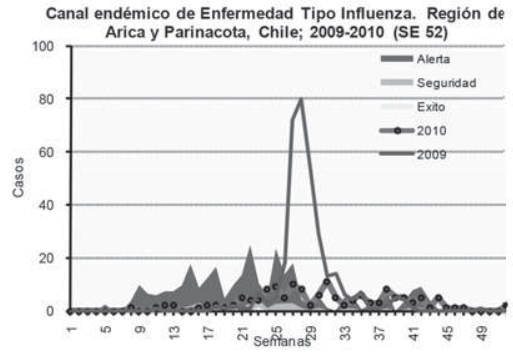

Tarapacá:. Desde la SE 19 se observa una discreta tendencia al aumento, con variaciones semanales. A partir de la SE 29 se observa un nuevo incremento que sobrepasa la zona de alerta, llegando a un máximo en la SE 35 (70,3/100.000). Desde la SE 31 se detectan casos de Influenza $A$, que se mantiene hasta la semana 40. En el 2009 la tasa máxima se alcanzó en la SE 26 (855/100.000 hab.)

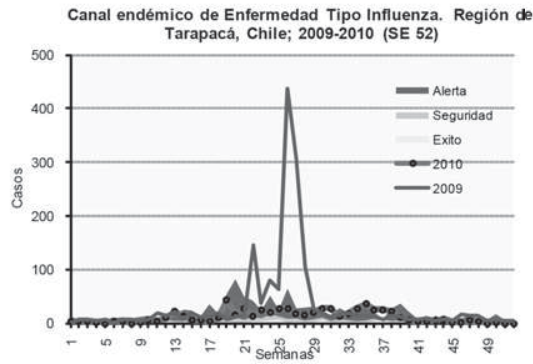

Antofagasta: Desde la SE 24 se registra un discreto aumento, (tasa 8,6/100.000 habitantes la SE 27), que luego disminuye. A partir de la SE 36, se observa un nuevo incremento que sobrepasa la zona de alerta, alcanzando una tasa de 19,3/100.000 habitantes (SE 37 y 38 ), posteriormente disminuye.

En el 2009, a tasa más alta se observó en la semana 27 (207/100.000 hab.).

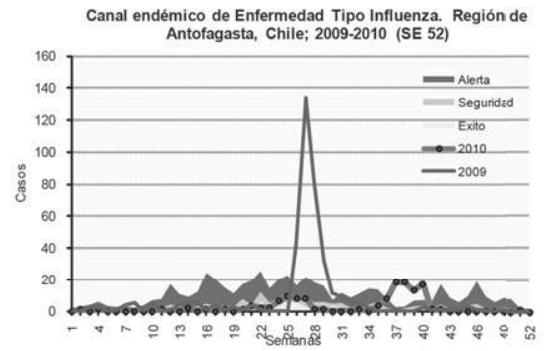


Atacama: Hasta la SE 35 se registraba solamente un caso aislado de ETI (semana 17). A partir de la SE 36 se detecta un aumento con una tasa de 12/100.000 habitantes, que disminuye posteriormente.

En el 2009, la tasa máxima fue en la SE 27 (128/100.000 hab.).

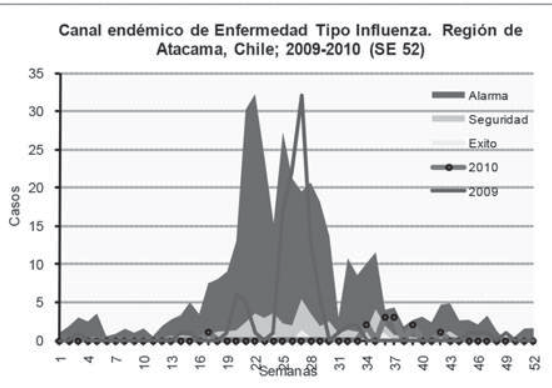
ico de Enfermedad Tipo Influenz
Atacama, Chile; 2009-2010 (SE 52

Canal endémico de Enfermedad Tipo Influenza. Región de

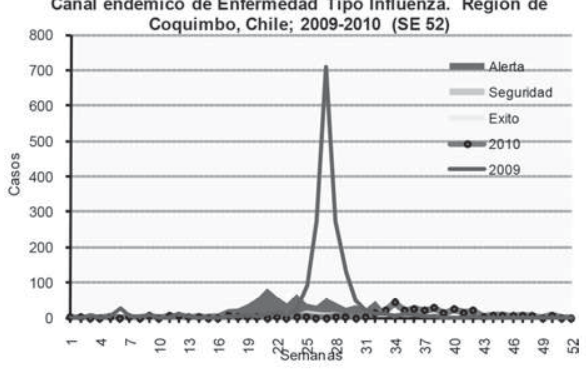

Coquimbo: Desde la SE 32 hay una tendencia al aumento llegando a un máximo la semana 34 (tasa de 54,6/100.000 habitantes), posteriormente disminuye.

En el 2009, se observó un máximo en la SE 27 (902/100.000 hab.)

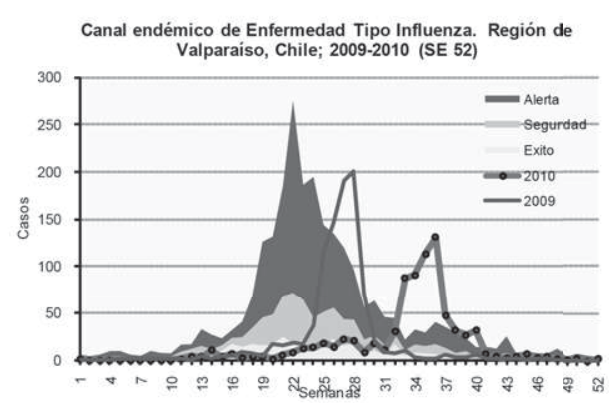

Valparaíso: Se observa una tendencia al alza desde la SE 32, alcanzando en la SE 36 un máximo con una tasa de 65,5/100.000 habitantes, sobrepasando la zona de alerta por 8 semanas. A partir de la SE 37, presenta un descenso significativo. Desde la SE 33 a la 38 se detectan casos de Influenza $A$ en los centinela.

En el 2009, el nivel más alto se registró en la semana 28 (110/100.000 hab.). 
O'Higgins: Hasta la SE 35 se han notificado casos esporádicos de ETI. En la SE 36 se observó un alza abrupta con un máximo de 64,8/100.000 habitantes, que posteriormente disminuye. Se mantiene por 9 semanas fuera del umbral en el canal endémico.

En el 2009, el máximo se alcanza en la SE 25 (173/100.000 hab.).

Maule: Desde la SE 31 se registra una tendencia al aumento alcanzando en la SE 38 una intensidad muy elevada (332/100.000 habitantes). Se mantiene por 9 semanas fuera del umbral en el canal endémico. Desde la semana 32 se detectan casos de Influenza A y B, lo que se mantiene a la semana 39 y 42 respectivamente. En el 2009, se alcanza el máximo la SE 27 (411/100.000 hab.).
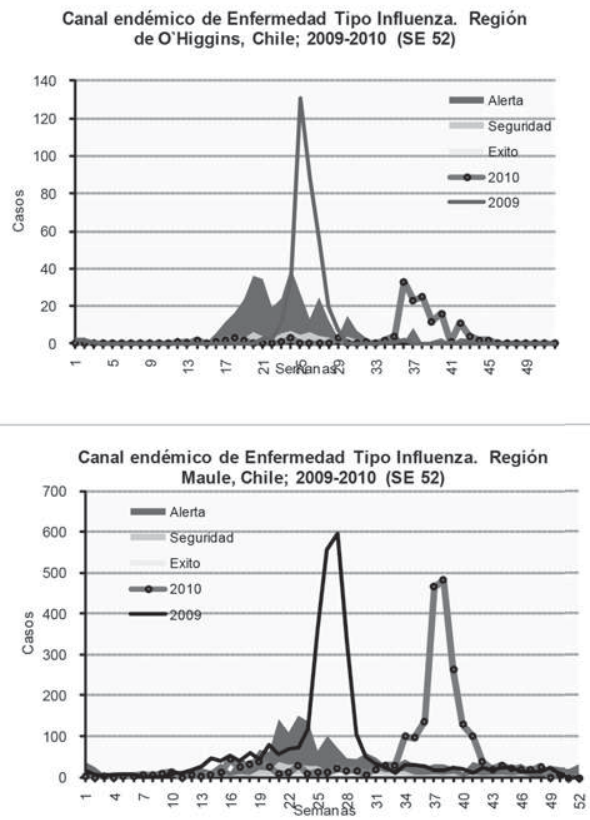

Bío Bío: Desde la SE 32 se observa un incremento sostenido, alcanzando una tasa máxima de $132 / 100.000$ en la SE 36, manteniéndose sobre la zona de alerta por 8 semanas. Desde la SE 32, en Concepción se detectan casos de Influenza $A$ y a partir de la semana 34 Influenza $B$; hasta la SE 40 y 41 se detectan casos de Influenza A y B, respectivamente. En el 2009, la vigilancia reflejó un máximo en la SE 25 (tasa de $118,7 / 100.000$ hab.).

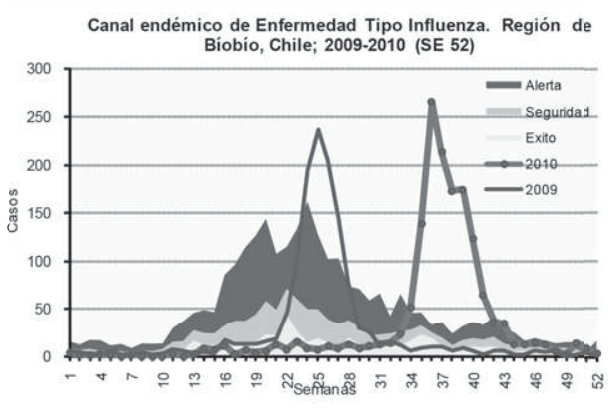


Araucanía: Desde la semana 32, se registra una tendencia al aumento, alcanzando un máximo la SE 35 (tasa 62,4/100.000 habitantes); manteniéndose en la zona de alerta por 8 semanas, posteriormente disminuye.

En el 2009, el máximo se alcanzó en la SE 25 (tasa 60/100.000 hab.).

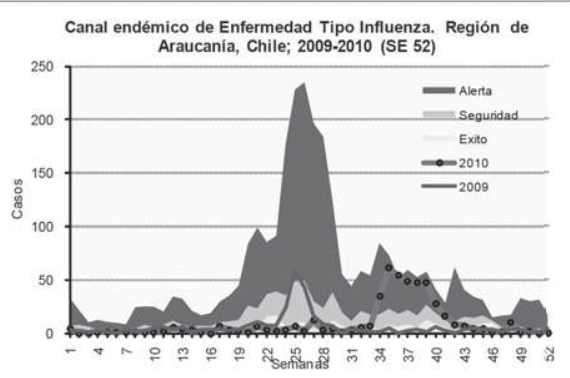

Canal endémico de Enfermedad Tipo Influenza. Región de Los Rios, Chile; 2009-2010 (SE 52)

aumento, con un valor máximo en la SE 30 (41,5/100.000). A partir de la SE 34 se observa nuevamente un abrupto aumento, con un máximo en la SE 36 (194/100.000 habitantes), que disminuye posteriormente. A partir de la semana 21 se detecta Influenza A y desde la semana 35 se observa un aumento de Influenza $A$ y $B$, que se mantiene hasta la semana 38. Se detectan casos aislados en la semana 45. En el 2009, el mayor número de casos ocurrió la SE 26 (tasa de 188/100.000 hab.).

Los Lagos: Desde la SE 23 se observa un aumento que supera desde la SE 28 la zona de alerta. El máximo se registra en la SE 36, (tasa 178,2/100.000 habitantes) y se mantiene con intensidad muy elevada hasta la semana 37, para bajar posteriormente. Desde la SE 13, se han confirmado casos de influenza H1N1 y a partir de la SE 34 influenza H3N2. Hasta la semana 41 se detecta casos de Influenza A.En el 2009, el mayor número de casos ocurrió la SE 24 (tasa de 206/100.000 hab.).

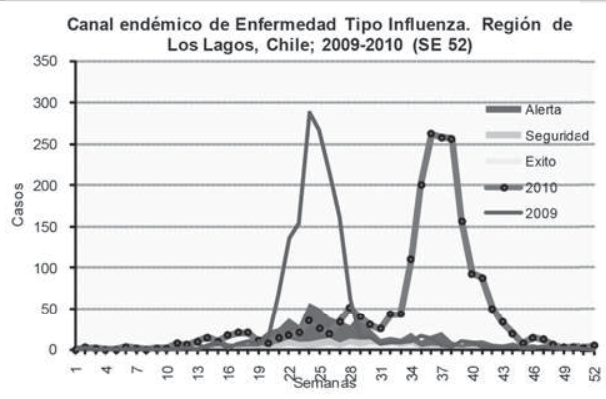


Aisén: Desde la SE 31 se registra una tendencia al alza llegando a un máximo la semana 39 (tasa de 90,5/100.000), sobrepasando la zona de alerta. Se registraron brotes de Influenza H1N1 en dos localidades rurales de la región. Entre las SE 33 y 40 se detectaron casos de Influenza A en el centinela ambulatorio.

En el 2009, el nivel máximo se observó en la semana 26 (162/100.000 hab.).

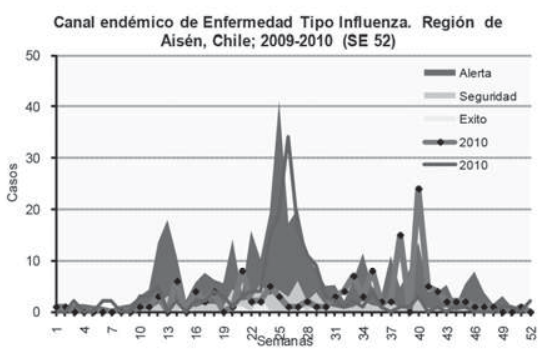

Magallanes: A partir de la SE 13 de 2010 se comienzan a presentar casos, registrándose en la semana 18 un máximo de 18,3/100.000 habitantes.

En el 2009 se observó el nivel más alto en la semana 26 (tasa de 771/100.000 hab.).

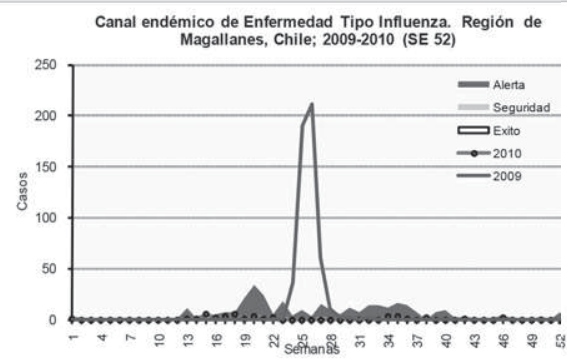

Metropolitana: A partir de la SE 21, se observa un discreto incremento, presentando en la SE 27 una tasa de 8,2/100.000 habitantes. Desde la SE 32 se observa un aumento significativo, alcanzando un máximo en la semana 36 (tasa 61/100.000 habitantes). Permanece en la zona de alerta por 8 semanas consecutivas, para luego disminuir. Desde la semana 32 se detecta un aumento en influenza A y en menor medida Influenza B. Se detectan caso de Influenza A hasta la semana 41 y B hasta la 36 .

En el 2009, la vigilancia de ETI en consultorios mostró el máximo la SE 25 (228/100.000 hab.).

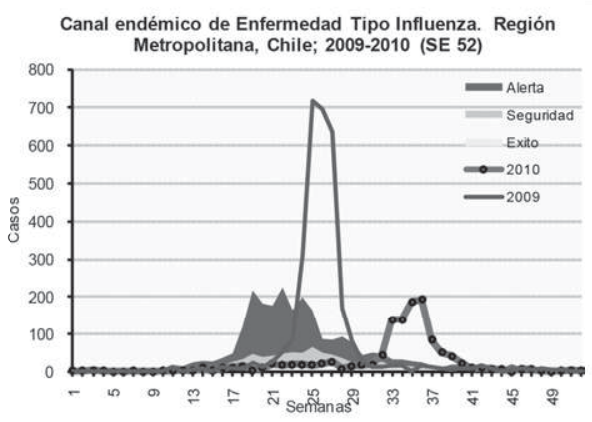


Anexo 2: Atenciones de Urgencia hasta la Semana 52 en Antofagasta, Viña del Mar, Santiago, Concepción, Temuco y Puerto Montt.

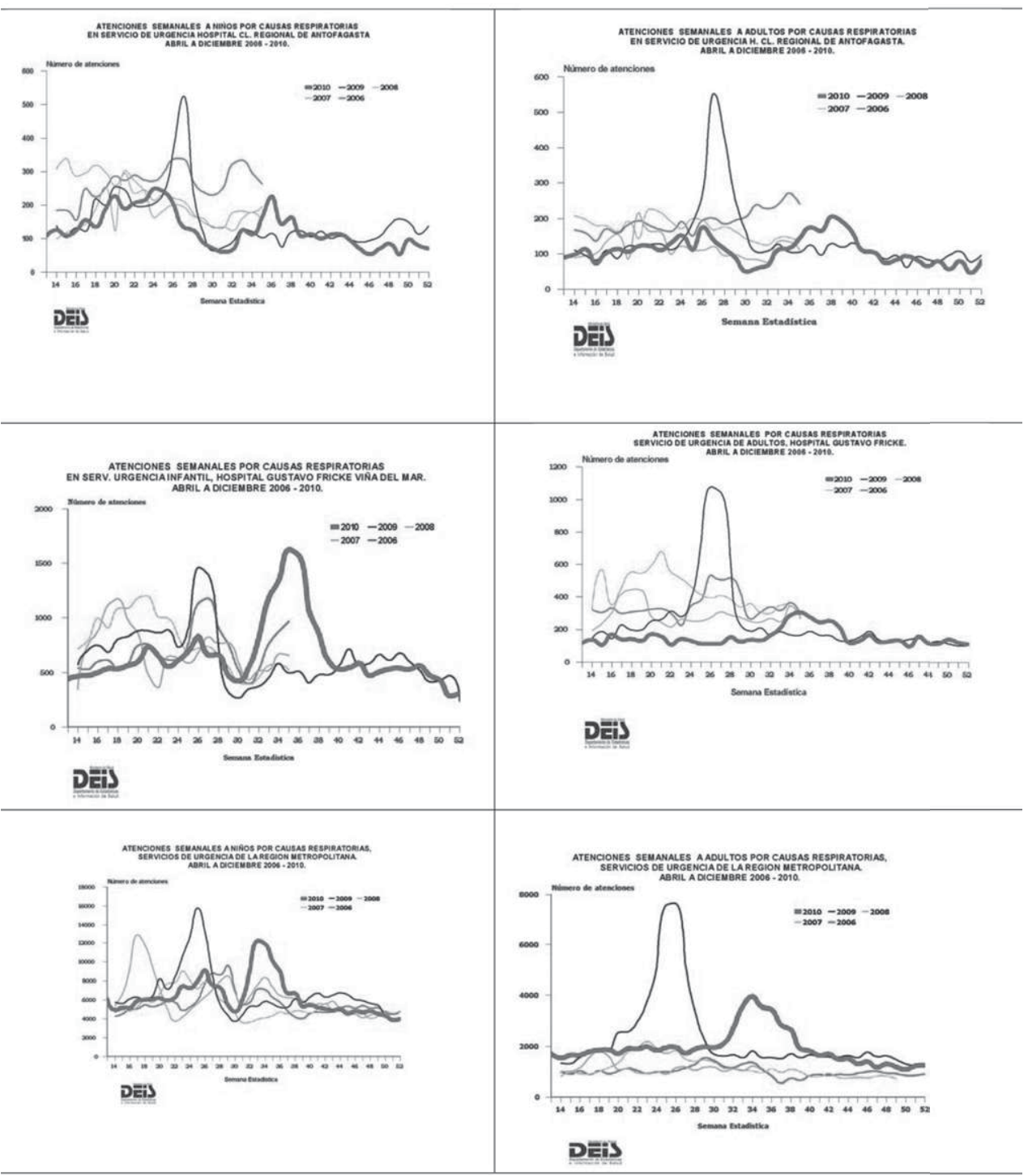


MINISTERIO DE SALUD DE CHILE

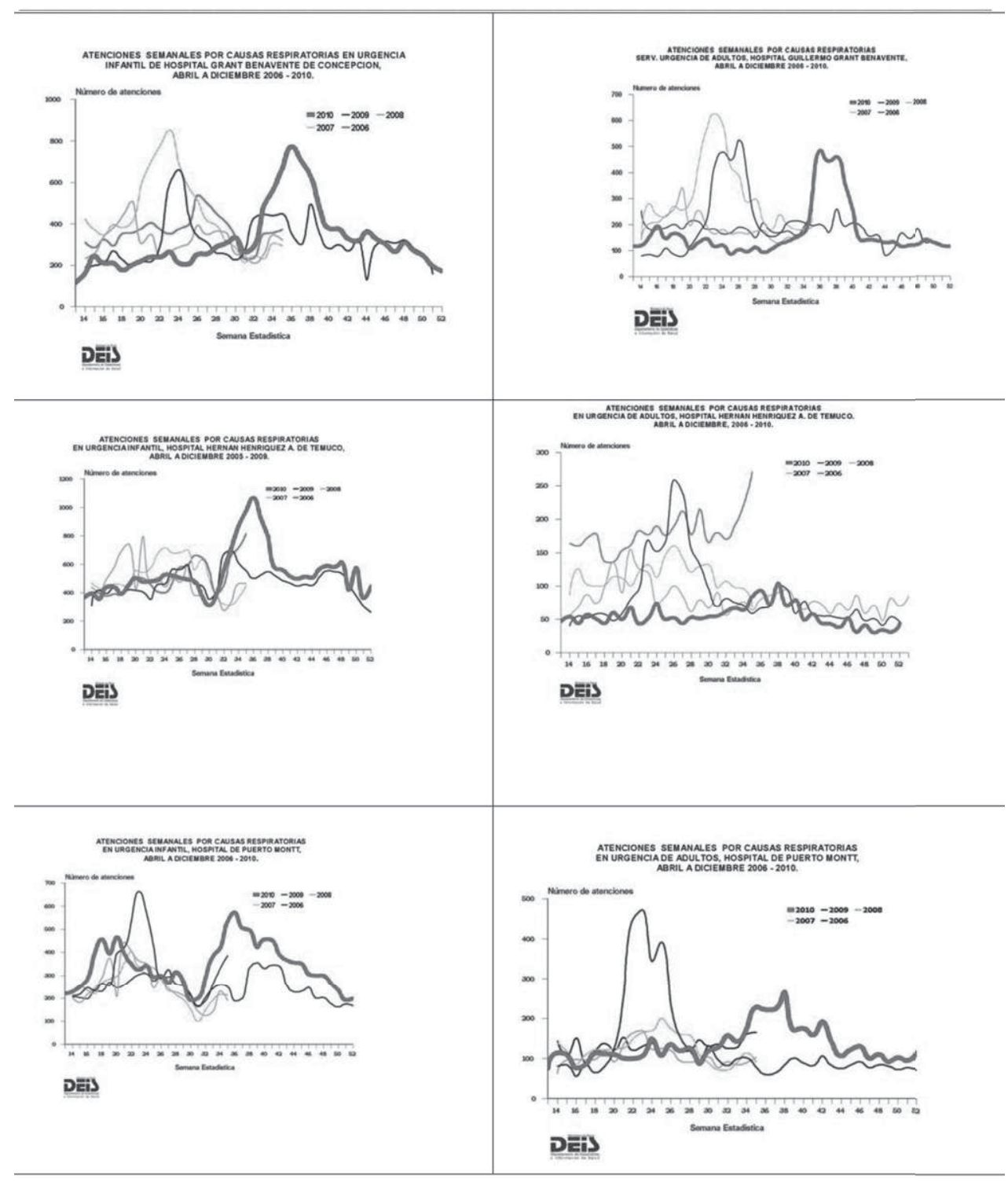




\section{SALUD MENTAL EN SITUACIÓN DE PANDEMIA. DOCUMENTO PARA MESA SOCIAL COVID-1934}

El 11 de marzo del año 2020, la Organización Mundial de la Salud calificó como pandemia el brote de Coronavirus (Covid-19). Por Decreto Supremo N¹04, de 18 de marzo de 2020, el presidente de la República declaró Estado de Excepción Constitucional de Catástrofe por calamidad pública en el territorio chileno. El 22 de marzo, representantes de las asociaciones de municipalidades, rectores de universidades, el Colegio Médico, la ex ministra de Salud, Carmen Castillo, y el representante de la OMS/OPS en Chile llegaron hasta La Moneda para reunirse con los ministros del Interior, de Salud y de Ciencia, Tecnología, Conocimiento e Innovación para constituir la llamada Mesa Social Covid-19, una instancia de coordinación, diálogo y colaboración para enfrentar la pandemia. Como parte de este trabajo, se encargó a la Universidad de Chile presentar las propuestas sobre salud mental. El informe fue entregado el 14 de abril por el rector Ennio Vivaldi. El documento fue encargado a un equipo de profesionales y académicos de la institución, conformado por las médicas Cecilia Morales, del Hospital Clínico; Verónica Iglesias, directora de la Escuela de Salud Pública; y Vania Martínez, psiquiatra e investigadora de Imhay; además de los psicólogos Roberto Aceituno, decano de la Facultad de Ciencias Sociales de la Universidad de Chile, y Sonia Pérez, académica de esa misma facultad.

Eldocumento afirma que "las pandemias causan graves sufrimientos psicológicos y sociales a las poblaciones afectadas. Esos efectos pueden amenazar la paz, los derechos humanos, el desarrollo de niños y niñas, y el desarrollo del país". El factor psicosocial debe ser transversal, pues de ello depende la posibilidad de construcción de una sociedad postpandemia. Es la primera vez que dicho enfoque, de manera integrada, se adopta en Chile para enfrentar una epidemia. Los planteamientos del informe se recogen en una plataforma habilitada en el portal del Ministerio de Salud y se publicaron el 20 de junio de 2020 .

34. Universidad de Chile, Salud mental en situación de pandemia. Documento para Mesa Social Covid-19, Santiago de Chile, 14 de mayo de 2020. Disponible en: https:/ / www.uchile.cl/portal/especiales/ covid19/163020/estrategia-nacional-para-salud-mental-propuesta-a-mesa-social-covid-19 


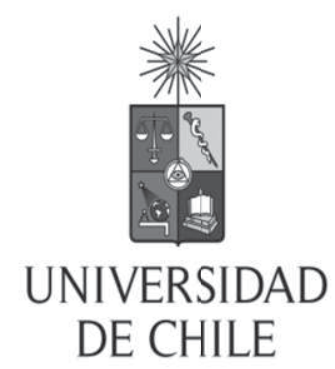

\section{SALUD MENTAL EN SITUACIÓN DE PANDEMIA DOCUMENTO PARA MESA SOCIAL COVID-19}


I.- Justificación: La salud mental es una de las claves para enfrentar esta pandemia Efectos en la Salud Mental

1. Efectos en la salud mental

2. Urgencia en prevención, atención y respuesta colectiva

3. Necesidad de un abordaje psicosocial

II.- Objetivos de una Estrategia Nacional de Salud Mental

III.- Criterios para una Política Estratégica

1. Articulación territorial

2. Intersectorialidad

3. Participación

IV.- Niveles de Intervención en Salud Mental

V.- $\quad$ Áreas de Trabajo

1. Apoyo e intervención psicosocial

2. Gestión de la atención

3. Capacitación y cuidado de personal que trabaja en el sector de salud

4. Rol de los medios de comunicación

5. Gestión de la información

6. Educación sociocomunitaria

7. Medidas de apoyo a las personas en confinamiento

8. Investigación e innovación

VI.- Focos de la Estrategia en Poblaciones con Necesidades Específicas

VII.- Conclusiones e Ideas Fuerza 
En tiempos de miedo e incertidumbre, cuando las amenazas a la propia supervivencia y la de los demás se convierten en uno de los principales problemas de la vida diaria, sería un error creer que la atención de salud mental puede esperar y que los esfuerzos deberían enfocarse en preservar la vida. Por el contrario, la salud mental es precisamente una de las claves para sobrevivir a esta pandemia y todo lo que conlleva a corto, mediano y largo plazo, desde la crisis potencial en la provisión de servicios de salud hasta ayudar a preservar y reconstruir una sociedad post-pandémica.

Chile es un país que evidencia, desde antes de la pandemia, dificultades de salud mental en su población, tales como altos indicadores de diagnóstico de depresión, altos índices de abuso de alcohol y otras sustancias y particularmente un alto índice de trastornos depresivos en adolescentes. Esto implica que el abordaje de los problemas de salud mental en contextos de pandemia sean distintos a los que puedan implementar otros países.

Tres son los argumentos que justifican una propuesta de Estrategia Nacional de Salud Mental en contextos de pandemia para nuestro país: la cualidad de los efectos de la pandemia en la salud mental, la urgencia de prevenir, atender y responder colectivamente y la necesidad de un abordaje psicosocial.

\section{Efectos en la salud mental}

COVID-19 tendrá un impacto en la salud mental de nuestra sociedad a corto, mediano y largo plazo

Los efectos sobre la salud mental observados y anticipados en esta pandemia son variados, de creciente magnitud, se dan en múltiples niveles y afectan distintas dimensiones. Así lo indica la evidencia empírica respecto al confinamiento y aislamiento social. 
Variados

Hay efectos normales:

miedo, ansiedad, rabia, angustia, nerviosismo, insomnio, irritabilidad, falta de concentración, confusión, pérdida de los refuerzos habituales, negacionismo, agresividad

Hay efectos patológicos:

trastornos adaptativos, conspiranoia, violencia intrafamiliar, trastornos del ánimo, trastornos de ansiedad, abuso de alcohol y otras sustancias, trastorno por estrés agudo, trastorno por estrés postraumático, suicidio,

Ambos pueden aparecer hasta meses después de la situación de crisis.
Creciente Magnitud

Mientras más prolongado el tiempo de distanciamiento social (físico), aislamiento y falta de previsión de un plazo de término para el cambio de rutina, más se presentarán en la población.

\section{Múltiples Niveles}

Se presenta en niveles personal, familiar, comunitario e institucional. En cada nivel el impacto tiene componentes y dinámicas distintas, por lo que requiere estrategias específicas.

\section{Dimensiones que Afecta}

No solo afecta la salud y la sobrevivencia, sino también la capacidad de desenvolverse en la vida cotidiana, la confianza y afiliación de las personas a las instituciones y las capacidades de respuesta del sistema de salud.

\section{Urgencia en prevención, atención y respuesta colectiva}

Las personas, familias y comunidades requieren involucrarse en el control sobre sus condiciones de existencia y proyección.

Hay que considerar que Chile presenta condiciones sociales de riesgo particulares en las que se anida el impacto en salud mental de esta epidemia: alta desigualdad social, alta desconfianza en las instituciones, vulnerabilidad social dinámica, alto malestar subjetivo y experiencias previas de desastres socionaturales.

Todas estas experiencias indican que la prevención de problemas de salud mental así como su atención requieren de enfrentamientos colectivos. Hasta ahora, las estrategias adoptadas instan a las personas y comunidades a participar activamente del control del contagio, a través de medidas como el distanciamiento social (físico), el aislamiento, la higiene, las restricciones de traslado, pero aun así para las personas no existe control sobre el contagio del virus y sus consecuencias. 
Se puede recuperar la percepción de control sobre la forma en que se convive con el riesgo, cuando las personas se sienten invitadas e involucradas a formar parte de una comunidad activa. Las personas, familias y comunidades son los principales protagonistas en que esto sea posible y su participación es fundamental en las estrategias que se impulsen.

Por lo tanto, existe la necesidad de priorizar la salud mental en el Plan Nacional de Enfrentamiento de la Pandemia.

Para este plan se cuenta con la experiencia de estrategias ya existentes de salud mental y emergencias (Protección de la Salud Mental en la Gestión del Riesgo de Desastres).

\section{Necesidad de un abordaje psicosocial}

La salud mental no es solo ausencia de enfermedad, sino también es bienestar subjetivo, es decir, la satisfacción y capacidad de desarrollo respecto de los proyectos de vida.

Ello implica implementar un abordaje que no se reduzca al nivel individual sino también a nivel comunitario y de las relaciones entre las personas y las instituciones sociales.

Las estrategias psicosociales han demostrado su efectividad en situaciones de emergencia y han jugado un rol clave en la recuperación de las comunidades una vez que ésta ha ocurrido, pero para ello debe comenzar a implementarse desde el primer día. Las estrategias de adaptación y respuesta que implementen personas, familias y comunidades dependerán principalmente de cuan protegida perciban su salud física y mental y la satisfacción de sus necesidades básicas. 


\section{Objetivo General:}

Desarrollar una estrategia nacional que aborde la salud mental en dos sentidos: fortaleciéndola como un factor clave para respuestas adaptativas a la pandemia y disminuyendo el impacto de la pandemia por COVID-19 a través de la prevención, la atención y el fortalecimiento de las capacidades de desarrollo de las comunidades.

\section{Objetivos Específicos:}

- Reducir los riesgos que vuelven más vulnerables a la población a partir del fortalecimiento de las variables psicosociales que protegen su salud mental.

- Facilitar el acceso equitativo y justo a beneficios y atenciones de calidad.

- Generar condiciones para el desarrollo de conocimientos, prácticas y competencias de salud mental desde las condiciones territoriales y formas de vida cotidiana. 


\section{CRITERIOS PARA UNA POLÍTICA ESTRATÉGICA}

El abordaje de la salud mental requiere una estrategia integrada que sea universal, con enfoque de derechos, de género y de edad (considerando el ciclo vital) como deben ser todas las políticas públicas. Enfatizamos dentro de ellos los enfoques de inclusión y de equidad en salud debido a las condiciones de desigualdad del país y proponemos además tres criterios particulares:

\section{Articulación Territorial:}

Es de gran relevancia la coordinación de actores que actúan en los niveles nacionales y de territorios. Es fundamental que se incluya una mirada idiosincrática de las regiones, dada su gran diversidad sociocultural y económica. Se requiere una conducción que permita el desarrollo de iniciativas locales coordinadas, especialmente a nivel municipal e intrasectorialmente.

\section{Intersectorialidad:}

Salud mental y apoyo psicosocial deben ser considerados de manera transversal en las medidas que tome la autoridad (ej. cuarentena, manejo de información de fallecidos, lineamientos de educación en casa a escolares, entre otras) y en los protocolos que se dicten. Es fundamental un enfoque intersectorial coordinado con actores como: Ministerios (Público, de Salud, de Educación, de Desarrollo Social, de Ciencia, Tecnología, Conocimiento e innovación, del Trabajo), Municipalidades, Superintendencia de Seguridad Social, SENAME, SENAMA, Servicio Nacional de la Mujer y Equidad de Género (SERMANEG), Sociedad Civil Organizada y la Academia, entre otros.

\section{Participación:}

Se debe considerar que los recursos y capacidades existentes en las comunidades potencian las estrategias de enfrentamiento al impacto de la pandemia. La identidad social, la reciprocidad, la confianza, la solidaridad, el apego al lugar, los lazos intergeneracionales y de vecindad, la identificación con símbolos comunes, han sido los factores que por excelencia protegen del impacto según la experiencia de desastres en este país. No obstante, estos factores no se presentan para todos por igual. Las capacidades de participación a consciencia convergen con las posibilidades reales de concretar las acciones colectivas. Una estrategia eficiente es la que considera las condiciones para la participación.

4. Desarrollo económico, social y humano: Las consecuencias económicas, sociales y políticas que tiene la pandemia, así como la forma en que las políticas sectoriales las afronten, tendrán un impacto profundo en el bienestar material y subjetivo de la población, en el cambio de su forma de vida, en la profundización o disminución de las inequidades sociales. 
La política para salud mental en la pandemia debe ser abordada desde esta perspectiva integral sin prevalecer factores económicos por sobre los sociales y humanos. 
Se propone adoptar la pirámide de intervención en Salud Mental y Apoyo Psicosocial difundida por la Inter-Agency Standing Committee (IASC)

Nivel 1: Consideraciones sociales en servicios básicos y seguridad

Nivel 2: Refuerzo de apoyo comunitario y familiar

Nivel 3: Servicios de atención no especializada

Nivel 4: Servicios especializados

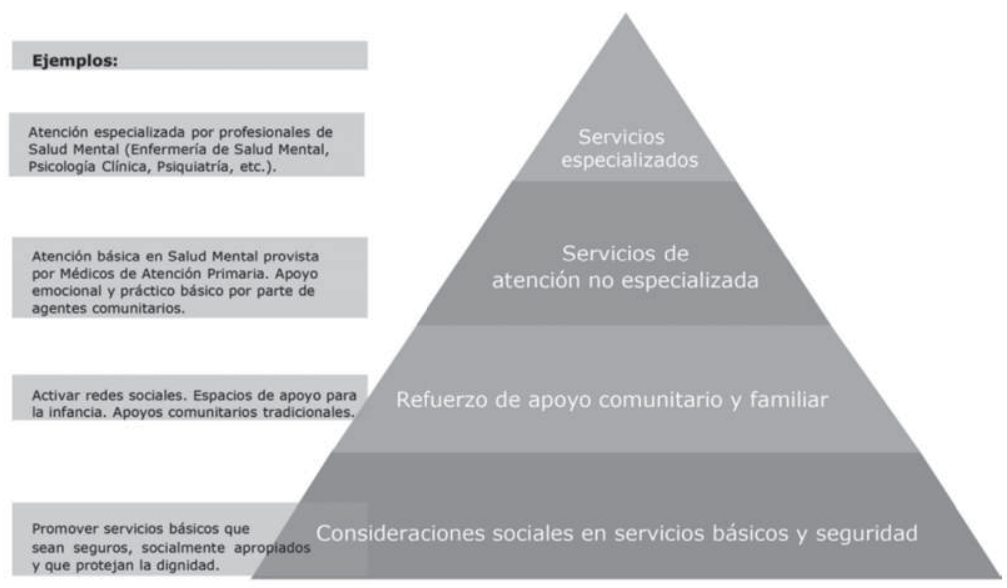




\section{V}

\section{ÁREAS DE TRABAJO}

\section{Planes y Programas de Apoyo e Intervención Psicosocial:}

* Se debe intervenir oportunamente problemas de salud mental, fortaleciendo el uso de tecnologías digitales y de atención a distancia.

* Se requiere evitar inequidades territoriales/regionales en el acceso a servicios remotos, para ello se debe superar las desigualdades en el acceso a Internet e incluir, por ejemplo, a la televisión abierta y radio.

* Además, es fundamental considerar la utilización de todos los dispositivos de Salud Mental existentes en la Red Pública de Salud.

\section{Gestión de la Atención:}

* Es fundamental garantizar la continuidad de los cuidados y protocolizar la atención durante la emergencia sanitaria, de forma que redefina, de ser necesario, los tipos de atención a realizar en cada nivel, y las responsabilidades.

* Se debe asegurar un flujo de derivación oportuno, controles profesionales, continuidad de los cuidados y/o de servicios en los distintos niveles de atención.

* Se recomienda considerar el uso de llamadas telefónicas, correos electrónicos y videollamadas como medios activos de pesquisa, atención y seguimiento a distancia en aquellas poblaciones que tienen acceso a estas tecnologías. A su vez, se deben generar estrategias e intervenciones focalizadas en poblaciones con barreras de acceso tecnológico (poblaciones pobres, población rural, zonas territoriales sin conectividad, personas mayores, población penal, entre otras). Las organizaciones vecinales de barrio y territoriales pueden apoyar con megáfonos, visitas domiciliarias a personas y familias vulnerables.

* También se debe garantizar la atención de pacientes crónicos, agudos en reciente tratamiento, y emergentes, secundarios a la crisis con equipos de salud locales.

\section{Capacitación y Cuidado de Personal que trabaja en el Sector Salud:}

* Se recomienda capacitar a los trabajadores de salud de primera respuesta en principios esenciales del apoyo psicosocial y la Primera Ayuda Psicológica (PAP).

* Asimismo, fortalecer el trabajo en equipo y el cuidado de estos.

* Se debe proporcionar acceso a fuentes de apoyo psicosocial a todos los trabajadores que responden en COVID-19. Se propone instalar una estrategia de monitoreo de la Salud Mental de los equipos de salud. Se piensa en especial a aquellos profesionales del área de la salud que están en trato directo con pacientes COVID-19, pero además, en la incorporación de todo el personal que tiene directa o indirectamente un mayor riesgo de contagio, por ejemplo, guardias y trabajadores de aseo de centros de atención de salud.

* También es importante capacitar en cómo abordar temas de estigma y discriminación en la manera como se comunican los contagios y las personas que se han visto 
afectadas. Humanizar a las personas que han enfermado y fallecido por la pandemia promueve conductas prosociales y puede reducir estigma y discriminación.

* Asimismo es fundamental que se garantice la provisión de Elementos de Protección Personal (EPP) y el rigor en el cumplimiento de las cuarentenas.

\section{Rol de los Medios de Comunicación:}

* Los medios de comunicación juegan un rol clave en el impacto en la salud mental de la población y de los trabajadores de la salud.

* Es necesario abordar la ética de los medios de comunicación en cómo comunican la pandemia, regulando la sobreinformación y evitando la confrontación entre actores sociales involucrados.

* Se requiere informar de forma clara, precisa y efectiva, las medidas necesarias para avanzar en el control de pandemia, y las razones que subyacen a tales decisiones. Ello ayuda a que las personas logren autogestionar su comportamiento en pro de su propia salud y la de las demás, evitando, por ejemplo entrar en aglomeraciones y aumentando el uso de mascarillas.

* Los medios de comunicación pueden aportar con educación informada a la población general y por grupos específicos en estrategias para manejo emocional, trabajo a distancia en los casos en que hay acceso, y educación escolar en casa entre otros.

\section{Gestión de la Información:}

* Es fundamental entregar información de manera oportuna, práctica y veraz, coherente, basada en el bien común y acorde a la evidencia.

* Se debe proporcionar una justificación clara para la cuarentena e información sobre los protocolos, garantizando que se proporcionen suministros suficientes para las personas.

* Las apelaciones al altruismo por parte de quienes establecen las medidas de confinamiento, implican recordarle al público sobre los beneficios de la cuarentena para la sociedad en general. Darle un significado de cuidado propio y de los otros, puede favorecer el acatamiento de la cuarentena.

* Se requiere fortalecer el rol de vocerías oficiales con empatía, transparencia y transmitiendo confianza.

* La comunicación del riesgo y de las medidas que se deben adoptar se pueden alimentar con conocimiento de la psicología para ser más efectivas en la adopción de comportamientos saludables, preventivos y solidarios.

\section{Educación Sociocomunitaria:}

* Se propone psico-educar a la población en estrategias para promover una adecuada salud mental en este contexto.

* Es útil la generación y difusión de material audiovisual (infografías y cápsulas educativas) para televisión abierta.

* Es necesario lograr la colaboración de los medios de comunicación en psicoeducación de la población y a la vez en diversificación de los contenidos aportando por ej. a la educación de niños y niñas en casa. 
* Se puede educar en el uso de herramientas de trabajo a distancia y en la distribución del tiempo para tareas domésticas, familiares y laborales, entre otros temas.

* Se recomienda socializar planes de enseñanza generales para los distintos niveles escolares que garanticen la continuidad de los proyectos educativos (televisión educativa) y regular las cargas escolares enviadas a casa.

\section{Medidas de Apoyo a Personas en Confinamiento}

* Se propone considerar mecanismos flexibles para autorizar a que puedan abandonar sus hogares las personas que lo requieran, por períodos cortos y de manera segura, cuando experimenten dificultades particulares con el confinamiento en el hogar.

* Para el caso de la violencia de pareja, sin una clara delimitación del tiempo de aislamiento, los estresores intensifican la violencia previa, en especial por la falta de herramientas alternativas para resolver conflictos y las resistencias por democratizar el espacio familiar (falta de distribución de las tareas en el hogar). Esa visión insta a promover la entrega de herramientas preventivas como también contar con más refugios de urgencia que faciliten salir del hogar si es requerido.

\section{Investigación e Innovación:}

* Es necesario identificar la magnitud de los problemas psicológicos que se presentan, desarrollar y evaluar el impacto de intervenciones en salud mental en contexto de cuarentena y de tecnologías para tratamientos a distancia, así como el impacto de las condiciones sociodemográficas preexistentes en el impacto.

* Se propone implementar un repositorio de las bases de datos de investigaciones en el área como una oportunidad inigualable y oportuna.

* El Ministerio de Ciencia, Tecnología, Conocimiento e Innovación de Chile podría jugar un rol protagónico en impulsar la investigación e innovación en esta temática. 
* Equipos de salud que trabajan con COVID-19. Esta población tiene alto riesgo de patología psiquiátrica debido a la exposición a jornadas prolongadas, el mayor riesgo de contagio e incluso de muerte, la sobrecarga de funciones, la presión para la toma de decisiones, la vivencia cercana del dolor de pacientes, familiares y colegas, el mayor riesgo de sufrir violencia física y psicológica durante sus labores, la exigencia de funcionar al tope de la capacidad de los centros, siendo estos muchas veces instituciones con importantes carencias de recursos.

* Pacientes contagiados y sobrevivientes de COVID-19.

* Familiares de contagiados y fallecidos por COVID-19. La pandemia va a generar duelos difíciles por el impedimento de la despedida. En este escenario es crucial que las instituciones de salud acompañen a las familias, les entreguen información directa y personalizada. También es necesario que se creen dispositivos virtuales, que permitan a las familias y amigos participar del rito del funeral.

* Personas con trastorno psiquiátrico y/o con abuso de alcohol y otras sustancias. Las personas hospitalizadas por una enfermedad mental no pueden estar obligadas a permanecer en esos entornos en contra de su voluntad, donde corren un mayor riesgo de infección, síntomas más severos y muerte. Se requiere mantener los tratamientos de pacientes ambulatorios tanto farmacológico como psicoterapéutico. Las medidas preventivas frente al contagio del virus deben ser especialmente reforzadas en esta población. En los servicios de hospitalización se debe tener especial atención en contar con EPP para el equipo de salud y para los hospitalizados. El consumo de alcohol y otras drogas es un problema de salud, que da cuenta de las mayores cargas de enfermedad en nuestro país. En situaciones de pandemia, aumenta el consumo de alcohol y otras drogas. Es imprescindible implementar medidas para prevenir y disminuir el consumo de alcohol y otras drogas, tanto para favorecer la contención de la epidemia COVID-19 como para disminuir las secuelas a largo plazo de la epidemia. Resulta muy relevante mantener la continuidad de los tratamientos de trastornos por consumo de sustancias y evitar el estigma de estas personas para el acceso a los servicios de atención médica.

* Personas mayores. Hay un gran desafío para afrontar la pandemia en este grupo, en particular en personas mayores que viven solas, aquellas cuyo sustento económico principal es su trabajo y quienes son personas mayores dependientes. Éstas últimas requieren del apoyo de un tercero quien es generalmente un familiar que ejerce labores de cuidado esenciales. Es por ello que las políticas de salud mental en este grupo etario deben incluir a la diada persona mayor-cuidador principal. Esto es válido también para las personas mayores institucionalizadas en establecimientos de larga estadía donde es importante resguardar tanto la salud mental de los residentes como 
del personal que trabaja en ellas. En ambos contextos (personas mayores viviendo en la comunidad y aquellas institucionalizadas) es necesario mantener un contacto periódico, a distancia pero afectivamente presente. El vínculo intergeneracional es fundamental. Sin embargo, dado que este grupo presenta barreras de uso tecnológico, es importante la entrega de información específica a través de otros medios como la radio, televisión, así como también facilitar el acceso telefónico a sus familias y redes y a instancias de apoyo psicológico provenientes de organismos públicos o privados especializados en la atención de personas mayores. Se requiere prestar especial atención a la percepción de soledad, riesgo suicida, sintomatología depresiva, riesgo de maltrato y considerar la salud mental de los cuidadores.

* Niños y niñas Se debe reconocer la vulnerabilidad a la violencia de niños y niñas y considerar que puede aumentar el riesgo de explotación y abuso sexual infantil. Se requiere evitar una exposición permanente a pantallas, buscar actividades físicas y de juego y trabajo, simples y en un ritmo cotidiano, pero no excesivo y disminuir las exigencias excesivas de educación a distancia (saturación de guías de estudio).

* Mujeres. Las mujeres se vuelven una población con mayores índices de afectación emocional por consecuencia del desgaste al asumir más responsabilidades en tareas de cuidado y regulación afectiva de los demás miembros del hogar, así como trastornos derivados del desgaste emocional. En el caso de mujeres y población LGBTI que sufre violencia de género en el contexto doméstico, el aislamiento intensifica la violencia previa y acrecienta la emergencia de situaciones de riesgo vital. Se propone contar con más recursos para dispositivos de acogida en casos de violencia de género; fortalecer medidas para denuncias y protección a las mujeres que se encuentran en una situación de riesgo; generar protocolos intersectoriales a nivel local que definan el circuito victimológico desde la denuncia, su paso por los sistemas judiciales penales y familiares hasta la intervención psicosocial; implementar programas de intervención a hombres que ejercen violencia; rondas periódicas de equipos de seguridad ciudadana y contactos telefónicos permanentes.

* Personas en situación de dependencia y/o discapacidad. Pueden correr un riesgo mayor de contraer COVID-19 debido a factores como los siguientes: obstáculos para emplear algunas medidas básicas de higiene (lavado de las manos por ejemplo) - dificultades para mantener el distanciamiento social debido al apoyo adicional que necesitan o porque están institucionalizadas; - la necesidad de tocar cosas para obtener información del entorno para apoyarse físicamente; - obstáculos para acceder a la información de salud pública. Según los trastornos de salud subyacentes, las personas con discapacidad pueden correr un riesgo mayor de presentar casos más graves de COVID-19 si contraen la infección porque: - la COVID-19 exacerba los problemas de salud existentes, en particular los relacionados con la función respiratoria o la función del sistema inmunitario, o con cardiopatías o diabetes; - podrían encontrar obstáculos para el acceso a la atención de salud. Las personas con discapacidad también podrían verse afectadas de manera desproporcionada por el brote debido a las graves perturbaciones de los servicios de los cuales dependen. Las políticas deben orientarse tanto a la persona dependiente $o$ con discapacidad como a su cuidador principal si corresponde. En consecuencia, se deben considerar, entre otras, las siguientes medidas: educar a personas dependientes o con discapacidad en la importancia de preparar un plan de contingencia (coordinar 
redes de apoyo formales e informales), asegurar que la información de salud pública y la comunicación sean accesibles (ej: usar lenguaje de señas, infografías simples, etc.), entregar apoyo económico y facilidades laborales a personas con dependencia/discapacidad y sus cuidadores, otorgar permisos de salidas temporales a personas con problemas de salud mental que se beneficien, facilitar el acceso a asistencia en varios formatos (teléfono, email, etc.) y permitir acompañamiento de niños y niñas que requieran hospitalización.

* Personas privadas de libertad. Se recomienda permitirles mantenerse en contacto con sus amigos y familiares, otorgar condiciones de seguridad de salud física y favorecer información oportuna.

* Personas que se encuentran cesantes o con precariedad laboral (informalidad).

* Migrantes. El impacto en salud mental está presente ya antes de la pandemia. En el período de cuarentena están presentes en todos los oficios que permiten continuar el funcionamiento social, expuestos a la indefensión frente al respeto de los derechos humanos por falta de documentación y prácticas de discriminación y racismo. Precisan ser considerados en las políticas generales y prevenir el maltrato de los medios de comunicación. 
Las pandemias causan graves sufrimientos psicológicos y sociales a las poblaciones afectadas. Esos efectos pueden amenazar la paz, los derechos humanos, el desarrollo de niños y niñas, y el desarrollo del país.

El estado emocional individual y colectivo, influye en la capacidad de la población general para adoptar medidas de prevención adecuadas y en la capacidad de respuesta asistencial de los equipos de salud.

La falta de confianza en la información entregada y en las medidas propuestas por la autoridad son una amenaza al enfrentamiento de la pandemia.

Por lo tanto:

* El componente psicosocial debiese convertirse en un eje transversal prioritario que impregne todas las actuaciones en la situación de emergencia para el abordaje efectivo de la pandemia y la disminución de sus consecuencias a corto, mediano y largo plazo.

* Es fundamental una coordinación de los distintos actores que participan en la respuesta.

* Es de suma urgencia el cuidado de la salud mental de trabajadoras y trabajadores de salud ("cuidar a quienes nos cuidan").

* Se requiere destinar recursos para la implementación de las estrategias propuestas.

En síntesis, los principios que deben guiar una Estrategia Nacional para la Salud Mental en contextos de pandemia son:

Flexibilizar para facilitar: las regulaciones de la vida cotidiana no pueden ser percibidas como un problema más que estresa las capacidades de adaptación. Es importante flexibilizar fechas de entregas, pagos, normas de acceso.

Visibilizar para potenciar: Las personas, familias y comunidades han desarrollado ya estrategias creativas de enfrentamiento a la vulnerabilidad: formas de comunicación a distancia, creación de actividades recreativas, generación de estrategias autoeducativas, cuidado a personas más vulnerables, por ejemplo. Es importante valorarlas como saberes de resiliencia y circularlas para el aprendizaje social. Aquí los medios de comunicación cumplen un rol fundamental. 
Regular para proteger: garantizar que la desigualdad no se acentúe, que no se incrementen los abusos ni la discriminación a grupos vulnerables, asegurar el salario de las personas cuando sobreviene una crisis económica, garantizar estabilidad en las condiciones estructurales de vida (precios y acceso a bienes y servicios); generar fondos solidarios, exigir a las empresas costear con sus recursos acumulados el acceso a condiciones básicas de sobrevivencia. 